

\section{UNIVERSITY OF CALIFORNIA}

\section{AT LOS ANGELES}
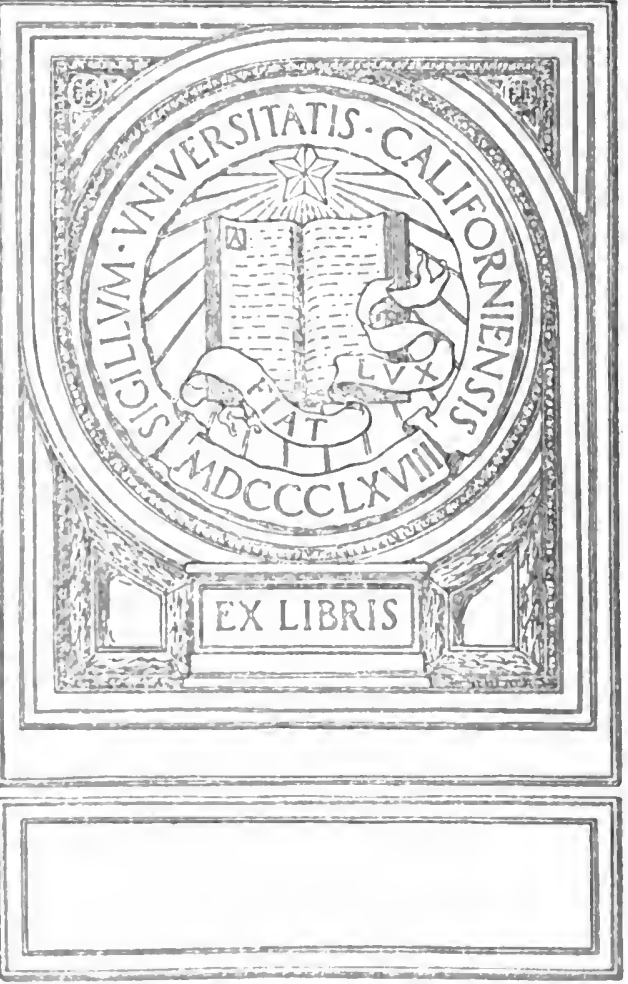


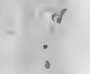

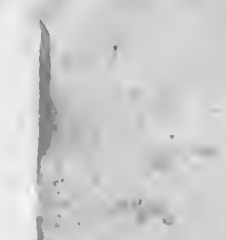

$\frac{1}{4}+x$

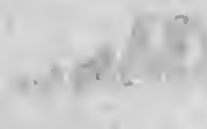

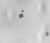
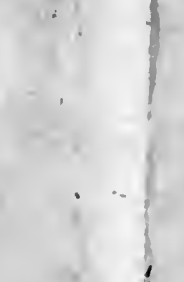

.

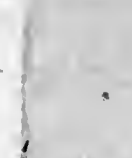




\title{
HISTORICAL SKETCHES
}

\author{
AND

\section{PERSONAL RECOLLECTIONS} \\ or

\section{A N CHESTER.}

INTENDED to IILUSTRATE THE PROGRess OF PUBLIC OPINION FROM 1792 TO 1332.

\section{BY ARCHIBALD PRENंTICE.}

SECOND EDITION.

LONDON :

CHARLES GILPIN, BISHOPSGATE STREET WITHOUT.

MA N CHESTER:

J. T. PARKES, MARKET STREET.

MDCCCLT. 
PRIXTED BY J.T. JARKES,

21, choss STRFT, MANCuESTER.

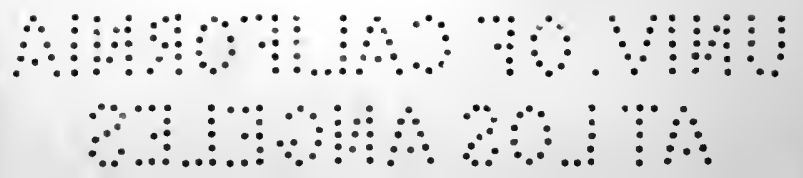




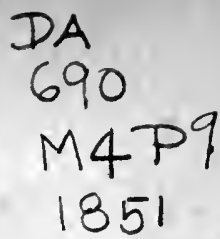

To

ELIZABETH, AGNES, AND BEATRICE PRENTICE.

OF CASTLE PARK, LANARK,

GREAT GRAND-DAUGHTERS OF ARCHIBATD PRENTICE AND ALEXANDER

REID, WHO, AT BOTHWELL BRIG, IN 1679, FOUGHT IN DEFENCE OP THE RELIGIOUS LIBERTY OP THEIR COUNTKY;

GRAND NIECES OR JAMES THOMSON, THE ACTHOR OF "THE SEASONS,"

" THE CABTLE OF INDOLENCE," " BRITANNIA," " LIBERTY," \&C.;

$\frac{x}{5}$

SISTERS OF DAVID PRENTICE, FOUNDER IN 1811, AND, UNTIL HIS DRATH IN 1837, EDITOR OF THE "GLASGOW CHRONICLE;"

THIS VOLUME IS RESPECTFULIY DEDTCATED, BY THEIR AFFECTIONATE COUSIN,

THE AUTHOR.

"Ours the triumph be

To circle social earth with fair exchange, And bind the nations in a chain of gold."

THONSON. 
Digitized by the Internet Archive in 2007 with funding from Microsoft Corporation 


\section{CONTENTS.}

CHAPTER I.

Party Spirit in Manehester in 1792; Church and King Clubs; Constitutional Society; Loyalty of the Publicans ; Printing Office attacked; Thomas Walker's Trial; Desertions from Reform; the War Spirit ; Persecution of Reformers Page 1

\section{CHAPTER II.}

The War Ferer; Famine and Tumult; the Short Peace; War Ferer again; Manchester Volunteers; Colonel Hanson's Trial in 1808; Joseph Nadin; Prosecutions Page 22

\section{CHAPTER III.}

Dissenting Ministers Bill; Orders in Council ; General Distress; Luddism in 1811; High Price of Food Page 37

\section{CHAPTER IV.}

Manchester Exchange Riot in 1812 ; Fatal Conflict at Middleton; the Spy System; Sidmouth's "Wholesome" Sercrities; Cost of the War; the Time of Reckoning ....................... Page 48

\section{CHAPTER V.}

Manchester in the First Year of Peace; Enactment of the CornLaw; Faint Opposition in Manehester; Fallacy about Wages; the Principal Reformcrs in 1815; Thirty-Eight Weavers Apprehended -their Trial and Acquittal Page 66

\section{CHAPTER VI.}

The Second Year of Peace; Agricultural Riots, and more Sererities; William Cobbett; Samuel Bamford and the Radicals; the Blanket Meeting; the Ardwick Plot; Waddington the Spy; Cowardice of Ministers Page 83 


\section{CHAPTER VII.}

The Spies Effectually at Work; Oliver tho Spy; Derbyshire Insurrections; Cowdroy's Nowspnper; Social Persecution; Proposal to Emigrate; Hopes of Better Times; Power-Looms; Malthusian Doctrines Page 103

\section{CHAPTER VIII.}

Memorable Petition of the "Twenty-Seren" (1817); Elijah Dixon's and other Petitions; Debate on Mr. George Philip's Motion; Sidmouth's Hopes ................................ Page 122

\section{CHAPTER IX.}

Mr. John Edward Taylor's Trial for Libel-lis Defence and Aequittal Page 132

\section{CHAPTER X.}

The Radieal Agitation in 1819; Hunt's Visit; Hunt at the Theatre; Good Old English Drink; the Drillings on White Moss ; the Magistrates Alarmed; Declaration of the Alarmists..... Page 146

\section{CHAPTER XI.}

Meeting on 16th August 1819; its Violent Dispersion; Protest against the Dispersion; the Killed and Wounded; Relief of the Sufferers. Page 159

\section{CHAPTER XII.}

Subscriptions for the Sufferers; the Duke of Hamilton; the Oldham Inquest ; the Six Aets ; Hunt's Committal; Trial at YorkJudge-made Law and the Sentences

Page 172

\section{CHAPTER XIII.}

Re-action; Sir F. Burdett's Letter, and his Trial ; Trial of Harrieon and others ; the Press ; Fstablishment of the Guardian in 1821, its Prospectus, and its Caution; Market-street Commissioners, Page 193

\section{CHAPTER XIV.}

A Period of Calm; Malthusian Doctrines; Drunkenness; Iancnshire Banking; Proposed Issue of Paper Money; Trial of Mr. Waller for Preaching 


\section{CHAPTER XV.}

A Short Period of Plenty and Cheapness in 1822; Meeting on the Poor-Laws; the Bridge-street Gang; Trial of Ridgeway; John Dicas v. J. E. Taylor; Royal Institution

Page 231

\section{CHAPTER XVI.}

The Author's Purchase of Covdroy's Gazette in 1824; What might be done; the Mechanics' Institution 'Established; Wild Speculations; Meeting on the Corn-Law; the Catholio Association; Manehester Protestants ; Jonathan Hodgins; Establishment of the Courier (1825); the Pitt Club Page 245

\section{CHAPTER XVII.}

A Period of Great Distress; Bank Failures; Meeting on the Corn-Law ; Destruetion of Power-Looms; Meeting in St. George's Fields, and Critical Position of the Author; Factory Burnt, Page 265

\section{CHAPTER XVIII.}

Symptoms of Onward Morement; Meeting on the State of the Country (1826); Mr. Mark Philips's first Publie Appearance; Partial Admission of Foreign Corn; Formation of a Footpath Preservation Society; the Flixton Footpath Case. Page 281

\section{CHAPTER XIX.}

Canning's Corn-Law; Manchester Chamber of Commerce on the Corn-Law; Tory Bitterness; Penryn Seats, and Manchester petitioning for them; Debate on Penryn .................. Page 296

\section{CHAPTER XX.}

Local Agitation in 1828; the Gas Question; Riot in the Town Hall ; Application for a new Police Bill, and the Opposition to it; Contest in Committee; Defeat of the Promoters ; Final Settlement Page 311

\section{CHAPTER XXI.}

The Author in Diffeulties; His Failure; Establishment of the Manchester Times; the Editor's Pledge; O'Connell and the Forty. Shilling Freeholds Pago 328 


\section{CHAPTER XXII.}

The Dark Hour before the Dawn; a whole Year's Misery (1829); False Iopes held out; Disturbanees; Cause of the Distress; Catechism of the Corn-Laws; Mecting on the Corn-Laws; Mr. G. Jones and the Footpaths Society; Mr. J. E. Taylor's old Friends, Page 343

\section{CHAPTER XXIII.}

Symptoms of the Dawn; second French Rerolution, 1830; Wellington's Resignation; Manchester Political Union; Meeting for Reform; the Reform Bill; Another Meeting; Dissolution of

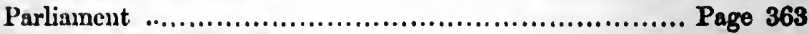

\section{CHAPTER XXIV.}

Recollections of Jeremy Bentham; Milton's Garden; the Author's Trial for Libel, 1831 ; Defence by IIinself, Aequittal, and Bentham's Letter of Felicitation Page 379

\section{CHAPTER XXV.}

The Delegate Parliament; Meeting in the Town Hall; Ministers Defeated; Exeitement in Manchester, and Extemporaneous Meeting; Meeting on the Camp Field; Riots at Bristol

Page 394

\section{CHAPTER XXVI.}

Meeting of the New Parliament; Morement in Manchester, and Deputation to London; Meeting on St. Peter's Fields; the Agitation throughout the Country; Passing of the Reform Bill Page 405

\section{SUPPLEMENTARY CHAPTER.}

Disclosures as to the Society for "Putting Down Lovollers and Republicans," and the Pitt Club ............................ Page 419 


\section{PRE FACE.}

Whex I disposed of my interest in the Manchester Times, and retired from its management, after twenty-three years' labour as a journalist, it was suggested that, as, for a considerable part of my life, I had taken part in morements for important purposes, a biographical memoir would be well receired. The suggestion was natural enough from those who, having read my newspaper from the time they left school until they were men, taking an active part in public business, regarded me as their political teacher. My reply was, that there was nothing in the events of my life that would interest any beyond the narrow limits of a local "school;" but, on further consideration of the matter, I thought that some account of the progress of liberal opinion in such a town as Manchester, and brief notices of the part, however humble, I had taken in its formation, would be not uninteresting and not uninstructive to its inhabitants, and those of the surrounding very populous district; and that there and elsewhere the history of what had been done might be an encouragement further to do.

In an interval of leisure, one of the rery few that I had enjoyed in a lifetime of constant oceupation, if not of 
exhausting toil, I prepared some "Historical Sketches and Personal Recollections," which were published in the course of 1848 , to the extent of about half of the present volume, in the paper which I had previously eondueted. In another cessation of labour, towards the end of the present year, I hare supplied some links of eonneetion, and continued the narrative up to the period when the Reform Bill was passed; retaining the title, however, because the work forms less a history than a sketch which may serve for history. I might have given more interest to the volume, had I made more revelations concerning persons with whom I have held converse or eorrespondence, but I have been withheld by the difficulty of deciding as to what might be considered as public and what as private confidenees, and have preferred to err on the side of retention; other men's feelings, with regard to publicity, having to be considered as well as my own. Almost all my statements may be rerified by reference to the publications of the period, exeept the curious diselosures in my last chapter, with which I bave been fayoured by a gentleman whose eharacter is a guarantee for their authenticity.

If there has been any ambition in my undertaking, beyond that of contributing to a plain-perhaps a suggestive - history of long-continued efforts to displace a stubborn obstruction to progress, it has been to associate my name for, it may be, a few years beyond my natural life, with 
that of a locality where,-notwithstanding many sharp public contests-not, however, embittered by malignityand some severe private struggles, the painfulness of whieh is now fast fading from my memory,-I hare enjoyed no inconsiderable amount of quiet happiness.

I could not expect that a local history of the progress of opinion would exeite more than a local interest. I find that the orders for the work, almost from Manchester alone, before its publication, amount to nearly the whole of the pretty large impression printed. I have, therefore, to announce that a 8ECOND EDIrIon will be put to press immediately, and published by the 1st of March.

Manchester, 13th December, 1850. 


\section{PREFACE T0 THE SECOND EDITION.}

To the satisfaction of having given to Manchester some sketches of what has been done as encouragement further to do, cireumstances seem to promise me the additional gratification of offering the incitement in a wider field, and furnishing material, for history of a wider seope. One competent critic says, that we can never have a satisfactory exposition of the progress of England, in social ameliorations and political independence, until we have special histories of it in erery important district; another, that this contribution will make some not unimportant additions to the matter from which the future national historian may glean; and another, that the work is "readable" beyond the locality within which I had supposed its circulation might be confined.

With such opinion and approval I offer this second edition to the public, with less doubt of my purpose being understood than when I put the first to press; and less as to the result of some other essay in the same direction.

Manchester, January 10, 1851. 


\section{HISTORICAL SKETCHES.}

\section{CHAPTER I.}

TIIE FREXCII REVOLUTIOX ANDD ITS EFFECTS.

THE terror oceasioned by the revolution in France, artfully used and kept in constant excitement by persons who had a deep interest in the conservation of existing abuses, delivered Manchester over, for thirty years, to the domination of the enemies of reform, in either Chureh or State. The prineipal inhabitants of the town, for a loug period had manifested, so far as they safely could, their attachment to the arbitrary and despotic principles of the Stuart family. They regarded the revolution of 1688 , moderate and aristocratic in its results though that was, as a dangerous innovation. They rejoieed in green oak branches on each successive 29th of May, and indulged themselves in secret bumpers to "The King." From their talk great hopes were entertained, both in 1715 and 1745 , that they would give erery effective assistance in the attempts to restore the "legitimate" race; but their spirit was humbled by the speedy suppression of both rebellions; and, in process of time, the doctrines of passive obedience and non-resistance, which had made them continue Jacobites, reconciled them to the remaining family, which had, in its turn, become legitimate, and had shown no great disposition to extend popular rights or religious liberty, or to innovate upon the previously existing relations between Chureh and hing. 
While the Church had a defender it mattered not much to them whether he was a James or a George; and, until the dawn of the Freuch revolution, which awakened a hope that every governmental institution throughout Europe was about to receive beneficial renorations, Jacobites and Hanoverians, Churchmen, and Dissenters, lived together in tolerable harmony, smoking their pipes and drinking their ale in peace and quiet converse about the progress of their new machinery and the widening prospects of manufactures and trade. Mr. Thomas Walker in his "Review" of some of the political events which had oceurred in Manchester, for five years previous to the year 1794, says that the commencement of virulent party feeling against the friends of reform might be dated from 1789, when the discussion respecting the Test and Corporation Acts occupied mueh of the public attention. In that year the dissenters, who had, for an unusual length of time, probably from their own supineness, enjoyed release from persceution, coneeired that the old spirit was dead or asleep, and that the time was farourable for a renewal of their application to parliament for the repeal of those acts. $\boldsymbol{\Lambda}$ torrent of insult and abuse was poured out upon the petitioners. "Their sentiments," said Robert Hall, writing at the period, "lave been misrepresented, their loyalty suspected, and their most illustrious characters held up to derision and contempt. The effusions of a distempered loyalty are mingled with execrations on that unfortunate sect, as if attachment to the King were to be measured by the hatred of dissenters."

The clergy, however, were alarmed, or pretended to be alarmed; and, on a sudden, the fears of those who eried out "The Cliurch is in danger," beeame as wild and absurd as ever they were in the days of Sacheverell and his party. At last they became sufficiently convinced of their power to coerce opinion in Manchester, as to call a meeting of those particularly attached to their own 
political doctrines, under the title of Members of the Established Church, in order " to consider of and consult about the impropriety of the applieation to parliament of the Protestant Dissenters to obtain a repeal of those salutary laws, the Corporation and Test Acts, the great bulwarks and barriers, for a century and upwards, of our glorious constitution in Church and State." The meeting held in pursunnce of this advertisement, was called a "public meeting" of the members of the Established Church. The room was nearly filled by the adherents of the high church party before any others were admitted. To inerease the solemnity, the clergy attended in their gorns and cassocks. Some opposition was made to the manner in which the meeting had been called, and the stratagem by which the room had been previously filled; and it was particularly objected, that, according to the rule which the town had adopted in the year 1788, the boroughreeve and constables had no right to call any meeting of the inhabitants, except a general one. But the clamour of the high chureh party was violent beyond description. They had come to act, not to argue. Resolutions, prepared beforehand, were put into the hands of the boroughreeve (not a properly elected officer, but the nominec of the Lord of the Manor), while he was in the midst of his speech, and explaining why he ealled the town together; and these resolutions, seconded even before they were read, were as hastily passed in the noise and confusion which prevailed. Among the resolutions thus passed was the following:- "That the religion of the state be the religion of the magistrate, without which no society ean be wisely confident of the integrity and good faith of the persons appointed to places of trust and pover."

The debate in the House of Commons on the Test and Corporation Acts, which gave rise to this outery, had taken place on the 8th of May, 1789. Mr. Fox expressed 
the wise axiom " that no human government had jurisdietion over opinions as such, and more particularly religious opinions," and the house so far agreed with him as to reject the motion for the repeal of those acts by a majority of only twenty, one hundred and twenty-two voting against it, and one hundred and two roting in its favour. The ery, howerer, of "the Church in danger" was, as it has been ever since, most powerfully influential, for on the next motion, made in March, 1790, the majority for rejection was one hundred and eighty-nine instead of twenty. Mr. Burke did his best on this occasion to frighten the house and the country. He dwelt on the destruction of the French church as a circumstance peculiarly shameful and seandalous, said that the dissenters were inducing the mob to view the wealth of the ehurch as a better object than the bribes of election candidates, and he read a letter written by Mr. Fleteher, a dissenter, from a meeting of dissenting ministers held at Bolton, Laneashire, stating that the meeting avowed such violent prineiples that he would not stay, but came away with other moderate men. It deseribed that one member, on being asked whether they meant to scek for anything more than the repeal of the Test and Corporation Acts, answered, in the language of our Sariour:- "We know these things which ye are not able to bear;" and on another member's asking "Gire us a little light on what you intend," they informed him that they "did not care the nip of a straw for the repeal of the Test and Corporation Acts, but that they designed to try for the abolition of the tithes and liturgy!" The house, horror struck at the declaration of these atrocious designs, decided by a majority of 294 against 105 that the church was too much in danger to allow of any concession to the conseientious scruples of dissenters. In those days loyalty was as prevalent as attachment to the by-lawestablished church. Mr. Walter, the editor of the Times, was tried and conrieted for libel in saying that the Dukes 
of York, Gloueester, and Cumberland were insincere in their professions of joy for the King's recovery, and ere his sentence had expired, he was brought from Newgate

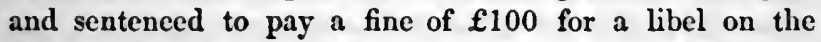
Prinee of Wales, and the like sum for one on the Duke of Clarence. The pulpit was arrayed against the pressand the pulpit had the best of it. It was ten thousand against ten.

The formation of "a Church and Fing Club" in Manchester followed the defeat of the dissenters. The members wore uniforms, with the representation of the Old Church engraved on their buttons, and their standing toast, while they could stand, in their clubs and convivial meetings, was "Church and King, and down with the Rump." The men who had no old-chureh buttons on their coats, and who would not swallow deep potations to the downfall of the rump, driven from the society of their ultra loyal and professedly religious townsmen, resolved to form an association of their own, and hence the origin, suggested by Thos. Walker, of the "Manehester Constitutional Soeiety," of which George Lloyd, Thomas Walker, James Darbishire, Thomas Cooper (a barrister), George Philips (the late Sir George), and Thomas Kershaw, were members. Some twenty years afterwards I used to hear the latter recount the perils of those days, and express his joy that, however little progress liberal opinions might have made, it was impossible then to get up a ehureh and king mob. $\boldsymbol{A}$ party without a press to represent its opinions could do nothing. The two newspapers in the town, Wheeler's Chronicle and Harrop's Mercury, began to refuse communications on the side of liberty. One of them, the Mercury, had been always violently devoted to the high ehureh party, and the other was easily induced to adopt the same course. Some members of the new society proposed to Mr. Mathew Faulkner, one of its members, to commence a newspaper, under the name of the Manchester Herald, which was 
established in March, 1792, and continued spiritedly to advocate liberal principles till judge-made law and moblawlessness put it down in March, 1793.

In May, 1792, the Constitutional Soeiety issued a deelaration of its objects, one of which was that " the members of the House of Commons should owe their seats to the good opinion and free suffrage of the people at large, and not to the prostituted votes of venal and corrupted boroughs." The society, in this manifesto, declared that, instead of endeavouring to excite sedition, it was solicitous, "by a timely and well-directed reform of abuses, to remore all pretences for it." Within a week after the publieation of this very moderate document, government issued a proelamation against any wicked and seditious writings, "printed, published, and industriously dispersed," and earnestly exhorted all loyal subjects to guard against such attempts to disorder the peace of society; and strietly eharged and eommanded all magistrates to make diligent inquiry to diseover the authors and printers of such "wicked and seditious writings," and to carry the laws rigorously into exeeution against them.

The dominant party resolved to hare a meeting on the King's birthday, 4th June, 1792, to address his Majesty in approval of the proclamation. $A$ few days before the time fixed for holding the meeting, the Constitutional Society issued an address, signed by Thomas Walker, president, and Samucl Jackson, secretary, earnestly exhorting the members of their own and similar reform associations in the town and neighbourhood to abstain from attemling the meeting, which, however upright the motires of the persons who called it, would have a direct tendeney at that crisis to endanger the liarmony and tranquillity of the town and ncighbourhood. "This preeaution was but too necessiry," says Mr. Walker, "for in the erening of Monday, the 4 th, a considerable number of people assembled in St. Amis-square to see some illuminations, 
exhibited by two of his Majesty's tradesmen, when the crowd became very tumultuous, and assaulted sereral peaceable spectators; they proceeded to tear up several of the trees growing there, one of which was carried with great triumph to the dissenters' chapel, near the square, and the gates attempted to be forced open, with violent eries of 'Church and King!'- 'Down witl the Rump-down with it!' \&c. Another tree was carried in the same riotous manner, and with the same exultation, to the unitarian chapel, in Mosley-street; fortunately, howerer, the doors withstood the attacks made upon them, the people were persuaded gradually to disperse, and about one o'clock in the morning the streets beeame quiet without any further damage." A beginning had been made, not a very formidable one, certainly, but still it was a beginning, which would show that if meddling persons like Mr. Walker would talk of reform, and would ask for the remoral of religious disabilities, there was a mob ready to break their heads for any attempt to persuade people that it was possible to amend the existing laws.

There are numbers of persons now alive who recollect seeing in Manchester taverns boards stuck up with the inscription-" vo JAConrss ADMITTED HeRE." So late as 1825 there was one of them in a public-house in Bridgestreet, as fine as gilding and decoration could make it, but it was removed then in deference to the change of opinion and to prevent its being burnt. The putting up of these articles-of-peace boards was part of a plan to prevent the discussion of reform principles in bar parlours. Soon after the proclamation of 1792 , and to prevent a meeting announced to be held to raise a subseription for the sufferers by war in Franee, a tax-gatherer, accompanied by several persons employed by the clergy, went round the town to all the innkepers and publicans, advising them, if they had any regard to the renewal of their lieenses, to suffer no socicties similar to the Constitutional to be held in their 
houses. The publicans gare a ready response to this call. "They thought their licenses," says Mr. Walker, " of more value than our custom." They, besides, ralued the custom of the jorial church-and-king men more than that of men who met to talk rather than to drink. The paper, said to be prepared for their subscription by one of the Fellows of the Collegiate Church, is too good to be allowed to perish :-

"Manchester, September 13, 1792.

"We, whose names are hereunto subseribed, being licensed innkeepers and ale-housekeepers, within the towns of MANCHEsTrR and SALFORD, justly alarmed at the treasonable and seditious conduct of a vell-knoten set of daring MISCREANTS, who hare called a public meeting to be held on Tuesday next, at the Bulls Head Inn, in Mfanchester, for the arouced purpose of assisting the Frexcr SATAGEs, as well as with a sIxCERE DESIRE of introducing similar calamilies to the inlabitants of this UAPPY and PROSPEROTS COUN$T R Y$, as those that now exist in Franec, take this rery necessary opportunity of publishing to the towns of MANcuester and SALFORD in partieular, and to the whole kingdom of GreAt Britais in general, our detestation of such wicked and abominable PRACTICES.

"And we do hereby solemnly declare, that we will not suffer any meeting to be lield in our houses of any cLCB or societies, however specious or plansible their titles may be, that have a tendency to put in force what those INFERNALS so ardently and decoutly wish for, namely, the Destructios or this covstry ; and we will be ready on all occasions to co-operate with our fellow-townsmen in bringing to justice all those who shall otfend in any instance against OC B YTCII-ADMIKED AND YOST EXCELLANT CONSTITUTION."

This was signed by 186 innkecpers and ale-housekeepers, afraid of losing their licenses, and anxious to sccure the custom of the party which was at once the most bigoted and the most thirsty. The public-house was now a most effective auxiliary to the church-the publican to the parson, and they formed a holy alliance against the mischicvous press. There was now hope that a more efficient mob might be organized than that which only tore up a few trees in St. Ann's-square; there was 
the example of the four days' riots in Birmingham, and the destruction of Dr. Priestley's house and half-a-dozen others; and there was a strong disposition to read a similar "wholesome lesson" to the disloyal of Manchester. A proclamation was issued by government on the 1st of Deeember, obviously to exeite and prepare the people for war against Franee; and meetings were held, one in Salford on the 7 th, and one in Manehester on the 11th of that month, at whieh it was earnestly striven to exasperate the publie mind. Thomas Cooper, the barrister, had issued an admirable address on the evils of war, but it produced no effect on the roused passions of the multitude. A rumour went out that there would be a riot that evening. It was known that there would be one. Persons went from the meeting to the public-houses, which became erowded, and thenee parties proceeded and paraded the streets with music before them, raising cries against Jacobins and presbyterians-meaning by the latter term dissenters - and carrying boards, on which the words "Chureh and King" were painted in large letters. As if by a preconeerted scheme, the various parading parties united in the Market-place, opposite the publication office of Faulkner and Birch, the printers of the Manchestev" Herald, and, amidst loud eries of "Church and King," they attaeked the house and shop with stones and brickbats, till the windows were destroyed and beaten in at the front of the house. Where were the friends of "social order" during this destruction of property? They were there eneouraging the drunken mob. Some respectable persons urged upon those whose duty it was to protect life and property to do their duty, but remonstrance was unarailable. Unite, the deputy-eonstable, on being applied to, said-"They are loyal subjeets; let them alone; let them frighten them a bit; it is good to frighten these people." This worthy then went to the mob, and elapping on the back some of the most aetire in the work of 
destruction, said-" Good lads; good lads ;" and perceiving some beadles attempting to do their duty, he said"Come away, d-n the house, don't come near it." A gentleman remarked, in the hearing of the Rev. Mr. Griffith, who was standing looking on-" What scandalous work this is!" "Not at all, sir," replied the reverend gentleman; " and if I was called upon, I would not act against them." One of the special constables was heard to say in another part of the town-"I'll give a guinea for every one of the Jacobins, houses you will pull down." The work was going bravely on, parson and publican doing their best. Mr. Allen Jackson went to the house of Mr. Nathaniel Milne, elerk to the magistrates (father to the present Mr. Oswald Milne), and urged Mr. Bentley, a magistrate, to preserve the peace; but he was told that it was "a scandalous, shameful, abonimable business to call out a magistrate on such a trifling picec of business as breaking a few windows." Mr. Jackson then found out the senior constable, and some of the constable's company hearing the application, threatened to kick him out of doors. So the printers and their friends were left to defend the premises. "It was good to frighten such people." From seven u'clock till eleven, four several attacks were made on Mr. Walker's house. "It was good to frighten" such a man; he was to be frightened in another way soon. The Attorney-Gencral was to take the place of a drunken mob. Mr. Walker had gathered some friends with firearms to defend himself; this was to be the foundation of a charge that he had obtained arms to wage war against the King! 'To this riot and the conduct of the authorities the attention of the House of Commons was called by Mr. Fox, when Mr. Windham, soon afterwards Minister at War, exeused the magistrates and their friends, tho mob, by saying-" The iudignation excited ngaiust Mr. Walker was more fairly imputable to his political opinions than to his being a dissenter. It was natural, and even justifiable, 
for men to feel indignation against those who promulgated doctrines, threatening all that was valuable and dear in socicty; and if there were not means of redress by law. even violence would be justifiable." To be a dissenter and a reformer was bad enough; to be a friend of peace was worse. According to Mr. Windham, a man's house might justifiably be pulled down about his ears, if he were opposed to the now contemplated war. The law, said Mr. Windham, was open to Mr. Walker, if he felt aggrieved at the attempt to destroy his house. The law courts were indeed open-to the Attorney-General, and it was resolved that if law could not reach the offence, judge-made law should. It would be hard if parson and publiean, magistrate and deputy constable, could not concoct something which wonld prevent his denunciation of war. It would be hard if juries could not be found in England such as those which in Scotland found Muir and Palmer, Skirving and Margarot, guilty. It would be hard if judges could not be found in England as loyal as those who presided at the Seotch trials, one of whom declared that "no man had a right to speak of the constitution unless he possessed landed property ;" another, that " since the abolition of torture there was no adequate punishment for sedition; and another, that "the nation was in a fever of disloyalty, and required blood letting." When a learned prelate on the bench of bishops asserted that "the people had nothing to do with the laws but to obey them," it might well be expected that a judge could be found to make the same assertion to a packed or subservient jury.

Nearly twelve months were required to collect or to make evidenec against Mr. Walker; to colleet, if any could be had-to make, according to the custom of the period; and during the greater part of the time he was in almost daily expeetations of being arrested, not merely for sedition but for high treason, $\Lambda$ drunken scoundrel, named Dunn, had been found willing to swear to anything; 
but there was a difficulty in finding a second witness equally disposed to give evidence " according to order." A man of the name of Pearsall was brought from Kidderminster to Manchester, and carried before the Rev. Mr. Griffith, a magistrate, son of the Rer. Dr. Griffith, also a magistrate, both of them zealous fricnds of " social order," and both very desirous to obtain evidence on which Mr. Walker might be convicted. We have his statement in the "Appendix to Mr. Walker's Trial," and here is the substance of it:-He was asked by the reverend magistrate if he had not seen arms in Walker's house, and if be had seen men exereised there; but as he could not say that he had, he was sent to the New Bailey prison, where he was kept from the end of June till the 9th of August, and visited there by Dunn and a mutual friend called Callaghan, who iustigated him to depose to having seen arms and exereised men at Mr. Walker's, assuring him that if he would swear so, he should have a pension as long as he lived; but Pearsall refused to listen to their proposals. They assailed him again, bringing with them pipes and tobaceo, and plenty of liqnor; and then Mr. Justice Griffith came amongst them in their prison earousc. The reverend magistrate shook hands very familiarly with Dunn, clapped him on the back, and called him an honest fellow; ordered some more drink, and drank with them; and then finding that Pearsall could not "recollect" anything in aid of Dunn's promised testimony, committed him for trial on the elarge of having, in Dunn's presence, damned the King!

Fiserybody knew that Mr. Walker and some of his friends were to be brought to trial, but the warrant did not come, and he learned that its service was delayed in order that his arrest might take place under circumstances the most painful to him. He sent his brother to the Rev. Justice Griffith, who told him that he had certainly signed a warrant against Mr. Walker for high treason, but he would not serve it until he got another witness, and 
claimed some credit for having prevented Unite, the then deputy-constable, arresting Mr. Walker at the funeral of his friend Mr. Jackson's wife! Applieation was also made to the Right Hon. Henry Dundas, the Home Secretary, to know when the warrant was to be executed; to which the reply was, that there were heavy charges against Mr. Walker, and that there would be no official delay in bringing them to trial.

To the extent of high treason, notwithstanding the open threats of the municipal and chureh authorities, they did not venture to proceed. At the spring assizes at Lancaster, on the 2nd April, 1794, Thomas Walker, William Paul, Samuel Jackson, James Cheetham, Oliver Pearsall, Benjamin Booth, and Joseph Collier, were tried on an indietment for a conspiracy to overthrow the constitution and government, and to aid and assist the Freneh (being the king's enemies) in case they should invade this kingdom. Law, afterwards Lord Ellenborough, as Attomey-General for the County Palatine, condueted the prosecution; Thomas Erskine, afterwards Lord Chanellor Erskine, the defence. The principal witness, well bribed and well drilled for the oceasion, was the man named Dunn, who swore that he had scen men learning military discipline in Mr. Walker's warehouse, shouldering muskets with fixed bayonets in a room, the roof of which was not seven feet high; that he had heard Mr. Walker say, - "We shall destroy the constitution by and by ;" that he had seen all the prisoners there; that he had heard Paine's work read aloud; that he had heard Mr. Paul damn the king and all kings; that he had heard Mr. Walker damn the king and all kings; that he had heard Collier damn the Freneh king, and wish all kings were served as he was; and other testimony to a like effect. The fellow's evidence was proved to be false, and it was also proved that he had confessed, on his knees before Mr. Walker, that the charges he had brought against him were false, and that 
he had been bribed to make them. Mr. Law threw up the ease. "You have acted very properly, Mr. Law," said Mr. Justice Heath. The jury immediately gave their verdict-" Not guilty," and the prosecutions against the other defendants were all withdrawn. Mr. Vaughan, one of the counsel for the defence, applied that Dunn might be committed. "We will undertake to prosecute him for perjury," said Mr. Erskine. Mr. Walker's reply to a subsequent remark of the Judge is too manly and memorable to be omitted:-

Mr. Justice Heath.-Let Dunn be committed; and I hope, Mr. Walker, that this will be an admonition to you to keep better company in future.

Mr. Walker.-I have been in no bad company, my Lord, exeept that of the wretch who stands behind me; nor is there a word or an action of my life, in which the public are at all interested, that I wish amended or undone, or that, under similar circumstances, I would not repent.

Mr. Justice IIeath.- You have been honourably acquitted, sir, and the witness against you is committed for perjury.

On the 29th of Oetober, 1794, six months after the acquittal of Mr. Walker and his friends, the Judges, under a special commission, sat at the Old Bailey, London, to try twelve persons who had been eommitted under a chargo of ligh treason. Mr. Hardy's trial came on first, and the Attorney-General, Sir John Scott (afterwards the Earl of Eldon), stated the case, in a nine hours' speech, and endeavoured to prove the eharges by the evidence of two government spies, Thyylor and Gosling. Erskine, who had so ably and spiriterlly defended Thomas Walker, and Gibbs, afterwards notorious as Sir Viceary Gibbs, were employed for the defence. After a trial of seven days, Hardy was pronouneed "Not guilty." Eleven days elapsed ere John Horne Tooke was put on his trial. He had summoned Pitt, the pilot who was afterwards to "weather the storm," 
to show that the doctrines and practices of the reformers in 1794 were precisely those which himself had adrocated in 1780. The minister attempted to evade a confession of his former principles and doings on the plea of forgetfulness; but Sheridan, also summoned as a witness, having manfully arowed and justified his own share in the proceedings of that period, Pitt felt himself compelled to correct his evidence, and admit that he was present at the meetings of delegates from sereral counties, convened for the attainment of parliamentary reform. The jury, amidst loud acclamations, pronounced a verdict of "Not guilty." John Thelwall was next put upon his trial and acquitted. The government, thus foiled in its attempt to establish cumulative and construetive treason, by evidence obtained under an odious and detestable system of espionage, abandoned the remaining prosecutions.

Thomas Moore, in his "Life of Sheridan," says :- "The severity of the sentences upon Muir and Palmer, and the daring confidence with which charges of high treason were exhibited against persons who were, at the worst, but indiscreet reformers, excited the apprehensions of even the least sensitive friends of freedom. It is, indeed, difficult to say how far the excited temper of the gorernment, seconded by the ever-ready subservience of the state lawyers and bishops, might have proceeded at this moment, had not the acquittal of Tooke and his associates, and the triumph it diffused throughout the country, giren a lesson to power such as England is alone capable of giving, and which will long be remembered, to the honour of that great political safeguard-that life-preserver in stormy timesthe trial by jury." There can be no doubt, however, that these prosecutions did create much terror. To run the risk of a trial for high treason, or for seditious conspiracy, on suborned evidence, was, to most persons, no trifling matter, eren where there was full confidence in the firmness and clear-headedness of juries. There were few persons who 
could undergo such an ordeal with the cool indifference and the gaiety of John Horne Tooke. There were desertions from the eause of peace and reform everywhere, and not a few in Manehester. The protest against war was almost confined to a few members of parliament, who arailed themselves of their privilege of speech to say what others dared not utter. Many reformers beeame whigs, and many whigs became nothing. The atroeities of the French revolution had furnished the exeuse for desertion of their prineiples. An able French writer says :- "From the time of the ministry of Lord North, societies were formed in order to petition for modifications of the representatire system; and the great mob of London, in revealing a hidden danger, had made the aristoeracy draw closer its ranks. Then eame the French revolution, which eompletely banded together men who had to dread every elange that might precipitate them from the top to the bottom of the social state. At the report of the sanguinary victories of Jacobinism, all parties were thrown into consternation, and the violence of the threats then directed against authority was such, that all the recolleetions, attachments and hatreds which had previously divided the higher elasses were hushed. In the House of Peers, the majority of the great families-the Portlands, the Fitzwilliams, the Spencers, and the Loughboroughs deserted the causo of the people. In the House of Commons, Windham, Burke, Anstruther, Gilbert Flliott, and a number of other eminent persons, left the benches of the opposition. In vain did their old friends pursue them with sarcasms, and apply to them the most cutting and eontemptuous epithets; the blow was struck, the whig party was rent asunder, and if it did not lose all influence in public affairs, it was indebted for this to the splendour of the talents of Fox, and the prudent sagacity of Lord Ianslowne."

Plausible excuse was not wanting for desertion of prin- 
ciple, and especially little wanting in Manchester, always distinguished for its attachment to the cause of "legitimaey." The hundred hours' massacre bad taken place. One thousand and eighty-nine prisoners had been brought from their prison cells in Paris, and piked or sabred in the open streets. The Princess Lamballe had suffered: "She shivers back at the sight of bloody sabres, but there is no return; that fair head is eleft with the axe,- - the neck is severed; that fair body is cut in fragments, with indignities and obscene horrors which human nature would fain find incredible." "That a shriek of inarticulate horror," eontinues Thomas Carlyle, "rose orer this thing, not only from French aristocrats and moderates, but from all Europe, and has prolonged itself to the present day, was most natural." Another shriek of horror arose when Louis XVI. was exceuted, not by the infuriate mob, but by deliberate judicial sentence; and another when Marie Antoinette was led to the scaffold; and all England's chivalry was roused to revenge the wrong to royalty and beanty. George the Third is reeorded to have sail,- " If a stop be not put to Freneh prineiples, there will not be a king left in Europe in a few years ;" and the nation joined in his fear of sueh a calamity. There was scareely need for $\Lambda$ ttorney-General prosecutions, espionage, or suspension of the habeas corpus act. The war spirit was kindled, and it flamed up as fiereely as king, or aristocraey, or ehureh could desire. The war was deeidedly popular; if it had not been deelared, the people would have used eompulsion to have it declared.

The nation had prospered; it had recovered from the effects of the American war; it had grown fat, and it kieked. In Fobruary, 1792, Mr. Pitt drew a most glaring pieture of national prosperity, proposed the repeal of some of the most burthensome imposts, and said there never was a period when, from the situation of Europe, we might more reasonably anticipate a durable peace than at that moment. In less than a year a war was declared which 
lasted twenty-three years, during all which period the blood of Europe was poured out like water, and treasure wasted as if it were dust; England's share in the cost of murder amounting to twelve hundred millions sterling. The grand result was that France regained a banished Bourbon to ensure her permanent peace, and Fngland received a new corn-law to enable her to pay the interest of the cnormous debt she had incurred in the contest! There was not even the apology for this wanton waste of life and treasure that funy aggression had been committed by the French people against this nation. It was a war undertaken solely to put lown opinions. On $\sqrt{\text { anuary } 28 \mathrm{th}, 1793 \text {, the king, in his }}$ message to parliament, informed them that he had determined to augment his forces, "for supporting his allies, and for opposing vieus of aggrandizement and ambition, on the part of France, at all times dangerous to the interests of Europe, but particularly so when connected with the propagation of principles subversive of the peace and order of society;" and yet the war was popular soon after and long after its commencement, especially in Manchester. The Thomas Walkers, the Thomas Coopers, and the Thomas Kershaws no longer needed to be held down by the hard liand of the law; they were held down by the harder hand of their fellow-townsmen; insulted, grievously uronged, without either remedy or the power of retaliation. The state of society here was favourable to this tyranny of opinion. Mueh of the social intercourse betreen the inhabitants took place in public-houses; the bar-parlour vas the resort of all the tradesmen of an evening. One of these places of meeting for conversation was deseribed by Dr. Aiken as the resort of some of the nost respectable inhabitants of the town, who met every afternoon to enjoy their pipes and their glasses; and we are told that John Shaw, the landlord, was a great favourite with the ladies, who often drank his health, because he most relentlessly shut uf his house at a certain early hour ercry night, and thus 
sent husbands and fathers soberly home to their wives and families; whereas, in the other tarerns they were permitted to sit late and drink deeply. The picture gires us no rery exalted idea of the refinement of the period.

John Shaw's bar-parlour soon became a Church and King club-room, and from every other such place of resort, "Jacobins" and "Dissenters" were excluded. We have seen that there were one hundred and eighty-six places of public concourse, into any one of which had a reformer or a friend of peace intruded himself, he would have been regarded as belonging to "a well-known set of daring miscreants," whom grossly to insult or assault would only be a proof of loyalty, religion, and manhood. There were then no neutral news-rooms, - no Royal or Mechanics' Institutions, - no Lyceums, no Athenæums. Even in the assemblies for music and dancing the "Jacobin" and his wife and daughters were liable to insult and vulgar abuse. The reformers were excluded from all society but that uound their own firesides, and even there they had careiully to guard against the introduction of the insidious spy; and in business transactions, none who could help it would deal with them. Throughout Lancashire the same coarse manners and intolerant spirit prevailed, though in different degrees. At Liverpool, comparatively refined Liverpool, about a dozen gentlemen, amongst whom were William Roseoe, Dr. Currie, and the Rev. William Shepherd, had been in the habit of mecting once a fortnight for literary discussion. "Eren this peaceful and unoffending company," says Roscoe's biographer, "was not exempt from the violence of party feeling. Upon the appearance of Mr. Pitt's proclamation against seditious mectings, and the consequent odium in which all who professed liberal principles were in rolved, the Litcrary Society found their meetings viewed with such jealousy and suspicion that it was thought proper, for the time, to discontinue them, nor were they afterwards resumed." IIr. Roscoe, writing to Lord Lansdowne on 
the subject, says:- " Under the present system erery man is called to be a spy upon his brother." The biogrnpher of Lorenzo di Medici, and of Leo the Tenth, the biographer of Robert Burns, the biographer of Poggio Bracciolini could not meet in comparatively liberal Liverpool, to enjoy a few hours of literary discussion before supper; and yet several highly respectable merchants, to escape from the insults and persecutions they had to endure in Manchester, sought relief by removal to Liverpool.

Thomas Walker deeply lamented the many defections from the cause of reform. He was a man of strong mental courage himself, and entertained a firm convietion that by boldness, perseverance, and union amongst reformers, the progress of liberal principles would hare been onward until they became triumphant. At the conclusion of his "Inquiry," he says he is conrinced,-- "That the dissenters of this kingdom have been at the commencement of almost every subject of liberal discussion of late years. But, however consistently and disinterestedly many of them hare acted, they hare, as a body, constantly fallen short of their own principles; they have excited opposition, which they have never completely supported; and through fear, or some other motive, they have been so strongly the adrocates of an overstrained moderction, that they have rather been the enemies than the friends of those who have ventured the most and effeeted the most for the rights of the people. That almost all the attacks upon individuals, which the enemies of liberty have directly or indireetly ventured upon, and which hare kept in the back-ground so many men of good intentions, but whom an excess of caution, or a timid kind of prudence, las prevented from acting, has been owing to the want of steadiness and coneert amongst the friends of liberty themselves. The timil desert the bold, till the bold become cautious of supporting each other with their presenee, and unable to do so with their property. That neither tho 
Birmingham riots, nor the Manchester riots, nor the Nottingham riots, nor the proseeutions, public or prirate, which hare taken place, would have happened, had not the timidity and want of union amongst the friends of freedom emboldened their enemies. Temper and moderation are truly valuable; but the professionally temperate and moderate men hare been the first deserters from, and have uniformly done infinite misehief to, the rights of the people. That men who mean to do good, must not look for their reward, or the effect of their exertions, during the existing generation. Such an effect they may, indeed, live to see, but it cannot be counted upon. Those who are not capable of acting upon this hazard, are not the men upon whom the public can fully depend; or who can pursue a great plan of public utility with satisfaction to themselves." Mr. Walker's observations on the timidity of reformers and dissenters are not much less applicable in this year, 1850, than they were in 1794 , and may have yet to discover that the boldest policy is often the most prudent poliey. It is quite possible that his son, as a magistrate, may yet hare to sign warrants of distress for non-payment of a church-rate in Manchester. A peaceable submission on the part of the dissenters, for seventeen years after Mr. Walker's comments upon their timidity, was rewarded by a kick from Lord Sidmouth, whici taught them that, to retain even the share of liberty they possessed, they must energetically demand thoee which were denicd to them. 


\section{CIIAPTER II.}

TIIE WAR AND ITS EFFECTS.

Mr. Wheelen, in his "History of Manchester," has recorded proofs of the "patriotism," as he, no doubt, regarded it, of Manchester at the commeneement of the war with France;-the insanity as many acknowledged it to be who lived to experience the results of the contest into which the nation so engerly entered. He commences his description of the rarious stages of that war ferer with the admission :- "This year (1793) was one of disquictude from commereial distress. The number of bankruptcies was nearly trebled, and popular discontent ran so high that it was necessary for light troops to parade the strects with torehes throughout the night. It was said that during this and one or two suceceding years, not less than twenty thousand persons had gone from the town to join the army; but the number was, no doubt, exaggerated." Proof of discontent there was, and proof of porerty, but greater proof of the prevalence of a pestilent war spirit. The men who enlisted might be partly out of employment from the depression of trade; but at the same time they were persuaded that the country required their services, and that to "fight the French" was the highest patriotism. The ardour to serve in the cause of the constitution and the country, says Mr. Wheeler, was very great. It is mentioned, for example, in March, 1749, that "Le GendreStarkie, Esq., has given $\mathfrak{f 1 0 5}$ towards raising the bounty given to recruits, five guincas a man, and others are following the example." "Harvey Aston, Esq., one of the intinates of the Prince, is engaged in recruiting in this country; he and nine others have undertaken to raise each one hundred men." "Thomas Leigh, Esq., of Lyme, 
proposed to raise six troops of Cavalry, and did so in fourteen days." In April, 1794, " the regiment of Independent Manchester Volunteers was ineorporated in the 53rd, or the Duke of York's Brigade, as soon as it arrived at Chatham." "His Majesty has been pleased to grant the title of 'Royal' to the regiment now raising, with an 'official promise' that the 'Royal Manchester Volunteers,' if reduced, shall eome to Manchester to be disbanded." On the 10th of May, a feu-de-joie was fired in St. Ann'ssquare, on account of advantages gained by the combined armics: six hundred and thirty stand of arms were sent from the Tower for the Manchester Volunteers. The success of Lord Howe, off Ushant, was announced at the Kersal Moor races, and assembled thousands received the intelligence with loud cheers : in the evening it was communicated to the audience at the Theatre by Mr. Ward, in the character of the Busy Body, and the audience shouted with exultation. In August, $£ 500$ were given by Lord Stamford for additional bounties to landsmen and seamen entering the navy; and on the 21st of the same month the Royal Manchester Volunteers were inspeeted by MajorGeneral Musgrave. Colours were presented to the regiment in St. Ann's-squarc, after which it marched to Liverpool to embark for Ireland: it subsequently became the 104th regiment. In October a subseription was obtained for raising a Fencible Corps for the County of Lancaster. The Loyal Association in Manchester and Salford formed themselves into a corps for the home defence. "The war, however, was not universally popular: in 1795 a petition was sent from the town praying for peace." There was dissatisfaction, but it scareely found an audible utterance.

Mr. Wheeler interrupts his narrative of the progress of the military fever, or rather continues it, unconscious of the conclusions to be drawn, by saying :- "In November in that year, the National Committee appointed to inquire into the high price of corn, announeed that the importation 
of foreign grain was desirable, and that to encourage it a liberal bounty should be offered, They also stated, that though the harvest generally was abundant, there was a defieieney of the wheat erop, and therefore the mixture of other grain with it was desirable. Handsome premiums were given to firmers bringing the largest quantity of provisions to the market. In addition to the sufferings from want, an epidenic fever was raging, and it was proposed, therefore, to erect fever wards. In February, 1796, the boroughreeve, clergy, and others, publiely pledged themselves, in a series of resolutions, to reduce their use of wheat flour at least one-third. Commereial distress pressed so heavily upon the people, that though they were relieved as far as possible by subseriptions and other means, their privations drove them to oceasional acts of violence, which required corresponding precautions by the authorities. On the 31 st of July an order was issued that all publichouses be closed by seven in the evening, and all private persons appearing in the streets after nine o'elock were compelled to give an account of themselves. On the 29th, several gentlemen being employed in examining the weights in the potato market, a disagreement arose between the spectators and the market dealers. $\Lambda$ tumult ensued; the people began to break windows, and the light troops were ealled in. The soldiers, after riding quietly but ineffectually amongst the people, were ordered to gallop through the midst of them, and they were thus dispersed. They assembled again in the morning at New Cross and in Newton-lane. Several loads of meal were seized and thrown away. On the arrival of the military and the magistrates the rioters returned home without doing any further misehief. On the 18 th of November an address was presented from the delegates of all the Loyal Associations in Manchester and Salford, congratulating the liing on his escape from the blow of a ruffian who had attempted his life on his way from the House of Peers. 
At this time; by general agreement, pies and puddings ceased to appear on the family table, in order to lessen the consumption of flour. Such soldiers as could be spared from duty were commanded to assist the farmers in thrashing out corn." Glory and want went hand in hand; splendid reviews and meal mobs were contemporaneous; and loyalty continued to characterize one class of the community, while poverty was crushing another.

At the close of the year, continues Mr. Wheeler, resuming his account of the war fever, a most respectable meeting was held, "to take measures for preserving liberty and property from republicans and levellers." Patrols were formed in the town shortly afterwards. Early in 1797 the first regiment of Royal Lancashire Volunteers received the thanks of his Majesty, conreyed through Lord Cornwallis, for their patriotic serrices in Ireland. In March, it is stated, the first and second battalions of the Manchester and Salford Volunteer Infantry were drawn out for the first time. This, therefore, must have been an additional new corps. In April the Lancashire and Cheshire Volunteers, the former commanded by the Earl of Wilton, offered to serve in any part of Europe. Shortly afterwards $£ 25,953$ 13s. were raised in the towns of Manchester and Salford and the neighbourhood, for the support of government.

But again is the narration of military preparation interrupted to say that " in November there was a disposition to riot, owing to the high prices of corn and flour. Subseriptions to purchase artieles of food, and retail them to the poor at a low rate, were liberally made." These interruptions in the history of local patriotism show that, besides the pulpit and the press, a new and more truthful teacher had eome into the field-wANr. Amidst the splendour of reviews and the presentations of colours, the ery for " bread" was raised, and put down by the strong hand, again to be raised when the laurels of war were won-and found to be worthless. In October, 1795, the King, on going to open parliament, 
wass surrounded by an immense crowd of persons of all ranks, crying out "Bread! Peace! No Pitt!" The new teacher was at work. In Norember, 1796, the French prohibited the import of English manufactures, the commencement of a war of tariffs; but the new teacher had not yet made his way to the mereantile classes, for in December the loyalty loan of eighteen millions was subscribed in fiftecn hours. In January, 1797, riots took place, occasioned by the enrollment of the supplementary militia. The new teacher had been amongst the multitude, showing the value of military glory. In a month afterwards the Bank of Fngland suspended cash payments, when the country was within twenty-four hours of barter. The bank was commanded not to pay when it had nothing to pay with ; and bankruptcy was called restriction!

There is a blank in Mr. Wheeler's history- from 1797 to 1803. There were no striking incidents to relate; but the new instructor was busy amongst the masses. Old inhabitants, of the industrial elasses, shudder at the recollection of the sufferings endured in 1800 and 1801, when wheat, which before the war was at $6 \mathrm{~s}$. a bushel, had risen to $16 \mathrm{~s} .8 \mathrm{~d}$., and this without any other adrance of wages than such as could be attributed to the competition for labour oceasioned by the introduction of new manufactures, the result of new mechanical inrention, while the wages of agricultural labour actually declined; and the poor rates, which at the commencement of the war amounted to

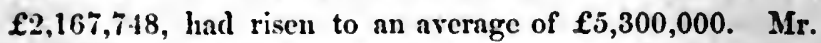
Hopkins, in his " Great Britain during Forty Ycars," says : " $\mathrm{By}$ the aristocracy, the elergy, the magistracy, and even the press, the war had been declared just and necessary, and the shouts at the stock exchange had been echoed by the capitalists in every part of the country. Poorhouses and jails admonished them that something was rotten in the state of Denmark-short-sighted sclfishness triumphed, and the most industrious and highly productive people on 
the face of the earth were doomed to bring into existence, in abundance all that is necessary, for the support and solace of man, only to have it abstracted by those around them."

Popular discontent continued to increase, and even those who had urged on the war began to think that the glory did not compensate for the commercial depression, the scareity, and the heavy pressure of a war taxation. Peace had become desirable, and, to pernit its attainment, Pitt retired from office; and in October, 1802, the war terminated-for a time-having cost $£ 284,000,000$ beyond what would have been required, had the country remained at peace, and occasioned the loss of half a million of human lives!

The peace negotiated at Amiens was of short duration. France complained that England retained Malta and other war-acquired possessions, in contravention of the treaty; England complained that the eonquest of Franee would disturb the "balance of power" in Europe. There was still a strong war party in England. The deadly coutest was recommenced, and, notwithstumding all the sufferings experienced by the English people, Buonaparte made it popular by his threats of invasion. The national combativeness was roused; and, in spite of all previous teachings, this country rushed into the contest with an animosity which nothing seemingly eould satisfy but the utter extinction of its " natural enemy." In this renewed madness Manchester largely participated. Mr. Wheeler, resuming the history of its "patriotism," tells us that on the termination of the peace, meetings were immediately ealled, arrangements for military bodies made, and subscriptions entered into with zeal and liberality. A general meeting of the lieutenaney of the county (Lord Derby in the chair) was held in Wigan, in obedienee to the King's command, to assist in earrying into effect the "law to enable his Majesty more effectually to provide for the defence and sceurity of the town during the present war." Schedules were sent to the various officers in the towns throughout 
the country, desiring them to make, without delay, returns of the inhabitants, eattle, and stock within their jurisdiction; the clergy and gentlemen were requested to give their assistance in furnishing the returns, and the county was divided into cight parts, ench portion being superintended by a lieutenant. Manchester constituted the sixth division, and was placel under the charge of John Leaf, Esq. A meeting was inmediately convened to consider the best means of assisting in the defence of the country, and it was agreed to accept the offers of James and John Leigh Philips, Fisqrs., to re-establish the roluntary corps, and also to support the proposal of Joseph Hanson Esq., for the formation of a voluntecr rifle corps, to furnish their own accoutrements, serre without pay, and mareh to any part of Great Britain. A subseription was raised to defray the various expenses, and the sacrifice of "lives and fortune" beeame the daily offering.

On the 27th of July, 1803, we are told, a meeting of the lieutenancy was held to receive the returns. The assembly expressed satisfaction at the number in Lancashire who were willing to aid the cause; at the same time they lamented that so large a proportion should have offered themselves as guides and pioneers, but more particularly as eonductors and drivers of eattle-a number infinitely larger than could be required for those purposes. No doubt they thought that the place of safety was with the cattle. In the mean time, by command of his Majesty, Lord IIobart forwarded to the Farl of Derby particular instructions for raising, training, and clothing the various military corps to be formed in the county. On the 16th of August Lord Hobart signified that his Majesty had acepted the offered scrvice of the regiments commanded by colonels Ackers and Philips, intimating at the same time that the title of "Royal" could no longer be permitted them, and that allowanees of twenty shillings per man for clothing, and one shilling per diem for twenty days' drill, would be issued 
to the commandants, to be by them applied as they deemed most beneficial. In little more than a week after the royal communication was received, the regiments numbered two thousand men. Those who were debarred from appearing in the field freely opened their purses, and the sum of $£ 22,000$ was raised in a very short period in Manchester alone. "The subscriptions in the neighbouring towns reflected equal credit on their respective inhabitants." Amongst the foremost contributors were: Sir Robert Peel,

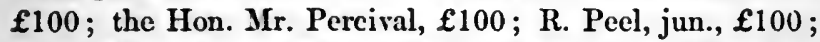
Sir O. Mosley, bart., $£ 200$; Earl of Stamford and Warrington, $£ 525$; \&c., \&c. But the bodies of military already mentioned were not suffieient to satisfy the ardour of the inhabitants, and within a very short time his majesty was pleased to aceept the services of the Light Horse Volunteers, commanded by Shakspeare Philips, Esq.; the corps of infantry commanded by Colonel Silvester; the St. George's corps, by John Cross, Esq.; and the Fourth Class Volunteers, by G. Philips, Esq.; the Hulme Volunteers, by Major Pooley; the Pendleton, by Captain Ablett; the Trafford, by Lieutenant Colonel Cooke; \&c., \&c. The Masons of the town formed a body, under the title of the "Loyal Masonic Volunteers." Those who, from legal exemption or other causes, did not enrol themselves in the military corps, registered their names as special constables for the defenee of the town and its vicinity. Pugnacity called itself patriotism, and took its full swing, persecuting the lorers of peace as if the love of peace were a erime.

In the madness of the men the women joined. "Nor must it be presumed," says Mr. Wheeler, "that the daughters of our land-the witehes of Laneashire-took no interest in the preparations carrying on around them. Designed by nature to labour in a more retired, yet not less useful and important sphere, our fair countrywomen employed themselves in adding to the comforts, and thereby to the efficiency, of the soldiery. They entered into a very liberal 
subseription to supply the troops with flannel clothing, the making of which was not entrusted to the hands of hirelings. Frequently, too, the soldiers were regaled at the mansions of the officers, the hostess being ever foremost in dealing out good English cheer to the men, thus adding to the enthusiasm of the brave by the condescension of the fair. Others presented standards and cockacles of their own handiwork to the troops. On the other land, fast days were proclaimed to supplicnte the Divine blessing on the country, and were strictly observed throughout the land."

Hundreds of mothers, hundreds of wives, lived to deplore the encouragement they had given to this military fever : not for loss on the battle field, but for the slower, though not less fatal, process of dissipation. Inabits of intemperance were acquired which became unconquerable. Tho beastliest drunkenness, the rudest manners, the coarsest swearings, the profanest onths, were regarded as nothing more than evidence of the most loyal attachment to the crown, and the most profound veneration for the chureh; and mothers and wives, in watching the wretched deathbeds of men ruincd in fortune, lealth, and character, had long to deplore, almost in tenrs of blood, the incitement they had given to fierce and ungovernalble passions, under a mistaken notion that they were encouraging patriotism and public virtue.

The working elasses were the first to experience the consequenees of that general folly in which they had so largely participated. They could not enjoy the luxury of war conjoined with comfort in their cottages. They had attempted to pull down the houses of peace-loving men, and their own aboles were the first to be visited by calamity. IIeary taxation fell with peculiar severity upon them; and in the gencral advance of prices, the consequence of a depreciated currency - $\mathrm{n}$ cheap rag currency-their wages were found inadequate to their support. Their only instruo tion had been, to be loyal and submissive; their reward 
for loyalty and submission was unbearable distress. They knew nothing of the cireumstanees which regulate wages. They believed that their employers could, if they would, increase the reward of their toil, and they asked the legislature to enforce justice to the "toiling multitudes." In the spring of 1808 they held many mectings to promote a bill for fixing a minimum rate of wages, and when they found that the masters opposed any sueh measure, their discontent was largely increased. A meeting of weavers was held in St. George's Fiells, Manchester, on the 2-1th of May, and resumed on the following day with such aceession of numbers as alarmed the magistrates, who, in their terror, deemed it prudent to call out the civil and military forees. There was no riot and no indiention of riot, exeept what might be suspected of men distrusting the government and angry with their employers. Without a riot, the riot act was read, and because the people did not instantly disperse, the military - the civil force trying nothing-were ordered to clear the ground, when one of the wearers was killed, several were wounded, and others arrested. It was the 16th of August, 1819, on a smaller scale, with less fatal effect. The military did not seem to like this service, for the officers and soldiers of the 4th Dragoon Guards presented a day's pay to tho widow of the poor man who was killed. In the course of the proceedings, Colonel IIanson, who enjoyed the confidenee of the weavers, and was popular amongst them for the support he gave to their much desired bill, endenvoured to persuade the men to disperse, by the assurance that their interests would be cared for; and for this "interference" he was indicted on a chnrge of having encourgged them to riot. The trial eame on at Laneaster, at the following spring assizes. Sergeant Cockell, for the prosecution, stated that 10,000 persons were assembled, and would not disperse; that Colonel Hanson, arriving on horseback, accompanied by his groom, asked Captain Trafford, who commanded the dragoons, leave to speak to 
the people; that the Captain said he should not, unless he could persuade them to disperse peaceably, but he thought the Colonel's presence would only irritate them, and begged that he would leave the field; and that the Colonel did not instantly leave the field, but, as he rode along, the people huzzaed, and he pulled off his hat and spoke to them. The witnesses for the prosceution, a sergeant and two corporals of the 4th Dragoons, and two of Nadin's constables, swore that they hearl him use expressions to the following effect: " My lads, your cause is good; be firm and you will succed. I will support you as far as three thousand pounds will go, and if that will not do, I will go farther." "Nadin and his faction shall not drive you from the field this day." "I an sorry your bill is lost. My father was a weaver, and I am a weaver, and I am the weavers' friend." In defence, the groom, who had attended the defendant the whole of the time. was examined, and swore that he never heard his master make use of the expressions sworn to by the other witnesses; that when the dragoons drew their swords, his master's horse becoming restive, he slipped off, walked a little way, and then mounted the groom's horse and rode off. Mr. Stennet, Mr. Norris, Mr. C. Satterthwaite, Mr. Brierley, and other gentlemen swore to the defendant's having exhorted the people to restrain from mischief, and none of them had hearl him make use of the other expressions ascribed to him.

Here was fair ground for acquittal, even had the evidence for the prosecution been all truc; for, with the exeeption, perhaps, of what was said of Nadin's faction, there was nothing alleged to have been said that could be interpreted into an encouragement of riot-and, be it recollected, there was no riot; but the colonel of volunteers had been desired by the captain in the army to retire, and he had not done so instantly, and it was necessary that such contumacy should be punished. The defendant was found guilty of having " by his language and conduet encouraged to hostile 
proceedings!' Judgment was delivered in the Court of King's Bench, on the 12th of May, and he was sentenced to be imprisoned for six months in the King's Bench prison, and to pay a fine of $£ 100$ to the King! Such a rerdict and such a sentence only increased the discontent of the weavers and the numerous class of working men who sympathized with them. A desire was expressed to pay the fine by penny subscriptions, but this was declined, and then it was determined to present him with a silver cup, and a deputation waited upon bim in prison to announce the intention. There were said to be thirty-nine thousand six hundred subscribers to this tribute-thirty-nine thousand six hundred persons thus protesting against the verdict and against the sentence. On the liberation of the prisoner and his return to Manchester, the roads were thronged with wearers anxious to celebrate his entry, but he prevented the intended demonstration by driving at a rapid rate to his residence in Strangerays Hall.

The effects of this ill-advised prosecution were long and injuriously felt. It introduced that bitter feeling of employed against employers which was manifested in 1812, 1817,1819 , and 1826, and continues, though divested of much of its virulence, to the present day. We need not speculate now as to the results, had a prudent and conciliatory course been pursued. The mischief was done; the good to be educed from the perpetrated evil is to make it a lesson for the future. Hanson, an impulsively benevolent man, had not the knowledge requisite to make hin a useful "working man's friend." Where were the men who could have reasoned with the weavers on the causes of their distress, and the remedics which they ought to hare demanded? Some were frightened out of the field by the prosecutions of 1794 ; some, shocked by the atrocities perpetrated during the French revolution, had lost their sympathies with the multitude, and regarded a movement for increased wages as a precursor of a demand for demo- 
eratic government; and many had sunk into a hopeless and selfish indifferenee. 'The mnmagement of town's affairs was allowed to remain in the hands of the self-styled "friends of social order," who swore by "Chureh and King," and thought that they better served God and their country by punishing the discontented than by endeavouring to remove the eauses of discontent. These miserable rulers were in their turn ruled by one of their own servants, the noted Joseph Nadin, the deputy constable, an official fixture, the master of successive aunually appointed boroughreeres and constables, whose occupation as a thief taker had led hin to believe that a poor man who asked what his superiors were not disposed to grant, would take it if he had the power. To this man's rule, strengthened, it is said, by seasonable loans to some of the magistracy, for he had contrived to make his office one of great profit, may be attributed mueh of the jealousy and hatred with which the working elasses in this town and neighbourhood regarded their employers, the local authorities, and the general govornment of the country. For more than ten years from the period of which we are writing, this coarse man was the real ruler of Manehester, under a suceession of municipal officers and magistrates, who thought they exercised a wholesome authority when, at his suggestion, they sought to repress, by every means of cocreion, the rising demand for political and social rights.

Another ill-adrised prosecution still more alienated the working classes from their old allegiance to the powers that were, and gave bitter effect to the writings of one who, in the most foreible English, knew well how to appeal to the feelings and the prejudiees of Englishmen. William Cobbett was sentenced to pay a fine of $£ 1,000$, to be imprisoned for two years in Newgnte, and afterwards to enter into recognizances to keep the peace, for a libel, reprobating the flogging of English soldiers under a guard of the Gernan legion. This larsh sentence, for what the 
public of England could not regard as a crime, and searcely ns an offence, gave additional popularity to Cobbett's writings, and nowhere were they read with more aridity than in Manchester. Loyalty also, as manifested in attachment to the royal family, was severely shaken by the exposure of the sale of commissions in the army, and eren offices in the church, by Mrs. Clarke, the mistress of the Duke of York. The exposure of an impudent robbery of the public by the commissioners for the sale of Dutch ships-one of them, the Rev. Mr. Bowles, a roluminous writer in defence of religion and morality-destroyed all confidenee in the administration of the finances of the country ; and the convietion of Lord Castlereagh of bartering offiees, and buying seats in parliament, a practice which he defended as " notorious as the sun at noon-day," strongly directed men's attention to the necessity of parliamentary reform.

Mr. Drakard, the printer of the Stamford Neus, had commented, with honest indignation, on what he ealled "the most heart-rending of all exhibitions on this side hell-an English military flogging," for which he was tried at Lincoln, found guilty, and sentenced to eighteen months'

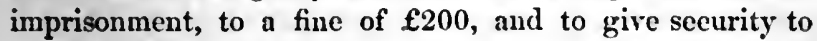
be of good behaviour during three years after liberation. Leigh Hunt and John Iunt, proprietors of the Examiner, a paper, the circulation of which was almost entirely confined to the educated classes, were proceeded against by criminal information, for having copied into their journal the article for the publication of which Mr. Drakard had been convicted and so cruelly sentenced; but they had the advantage of a London jury, and were acquitted, although Lord Ellenborough spoke of the peculiar danger, at such a time of doing anything to alienate the attacliment of the army, and pointed out the circumstances of an inflammatory tendency in the publication, which he had no hesitation in pronouncing a libel. His lordship had to encounter, sub- 
sequently a decper mortifieation in the acquittal of William Hone; and subsequently, also, the Hunts experienced the "glorious uncertainty" in their conviction for a libel on the Prince Regent, followed by a sentence which was obviously intended to include what was considered due to both offences.

In the early part of 1811 , great numbers of weavers having been thrown out of employment in the west of Scotland, a subseription was opened at Hamilton for the relief of the destitute of that place. They, however, refused to receive it as alms, but said they would be happy to carn it by their labour; and the subscribers agreed to expend the money in making a footpath by the side of the public road leading from Hamilton to Bothwell Brig, orer the ground that had been occupied by the covenanters before their bloody dispersion by the royal army under the command of the Duke of Monmouth. In about the first newspaper paragraph I ever wrote (it.was in the Glasgou Chronicle, conducted by my cousin, David Prentice), I made some comments on this noble resolve, which being seen by Dr. Mathew Baillie, brought from him a subseription of $\mathbf{f} 20$. Riding over the road some time after with a young friend of mine, on our way to my father's farm, the wearers, in whose soft hands the spade and mattoek were less easily urged than the shuttle, gladly relaxed from their work, and anused themselves with saluting us with coarse jeers ns we rode along. My young friend spoke indignantly of this insolence. I said- "I an glad that the poor half-starred fellows hare a joke left, eren if it be indulged in at our expense." I have thought of this incident occasionally when my reward for endeavours to serve the working classes has been the Lancashire groan-the most dissonant of all modes of expressing disapprobation. 


\section{CHAPTER III.}

THE DISSENTERS-ORDERS IN COUNCIL.

THE working classes had been alienated from the government not less by their sufferings than by indifference to their complaints, and the harsh treatment of those who befriended them in their adversity. The dissenters were still loyal; the merehants and manufacturers, though with less vehement zeal, still supported the administration. They were to be alienated in their turn. The self-complacent, self-sufficient Lord Sidmouth, in his zeal for the interests of the church, eontrived to render the gorernment which he supported unpopular with a great portion of the community, who might still have eontinued submissively to bear their political disabilities, had not a new insult been offered to them. His lordship, preparatory to bringing in his famous Dissenters' Bill, moved in the House of Lords, on the 2nd of June, 1810, for returus of licenses to preach issued in the various dioceses of England sinee the year 1780, and he was thus enabled to make the following transeript of the different ways in which the words "minister," "teacher," and "preacher of the Gospel" were spelt by them :-

"Preacher of the Gopel.

Preacher of the Gosple.

Precher of the Gospel.

Precher of the Gospell.

Preacher of the Gospell.

Preach of the Gospell.

Precher of the Gosple.

Precher of Gospell.

Prashr of the Goseppl.

Miniester of Gospell.
Preacher of the Gosper.

Preacher of teacher the Gospell

Bappist.

Preencher of the Gospel.

Teacher of the Gospell of Jesus

Christ.

A disecnting teacher.

Desenting teacher.

Decenting teacher.

Preicher of the Crospel."

These eighteen instances of ignoranee of orthography were proof positive that the licensed preachers were not " res- 
pectable." To this proof was added the testimony of Dr. Barrington, the Bishop of Durham, that the sectaries "assembled in barns, in rooms of private houses, or in other buildings of the most improper kind." Sidmouth consulted Dr. Coke, "the head of the Methodists," and " eompletely satisficd him." "Ilis apprehensions," says his lordship, in a letter to his brother, "are converted into zealous approbation." IIe consulted Dr. Adam Clarke, and satisfied him; he consulted Mr. Belsham, the celebrated Unitarian writer, and satisfied him. Thus fortified, he brought in his bill on the 9th of May, 1811. But Dr. Coke and Dr. Clarke had talked with others after they had been "satisfied," and found that they had made a mistake. Sidmouth's biographer says of a letter from Dr. Clarke : "It seems, from the learned doctor's account, that it was not the ministers, but the lay members of the Methodist connexion, who first sounded the alarm, and, by calling a general commillee, prevented the beneficial objects of the bill from being properly explained or understood." $\mathbf{A h}$, mischievous laymen!

The Methodists took the lead in the morement against the Sidmouth bill. The Rev. Richard Watson, then of the New, and the Rev. Jabez Bunting, of the Old Connexion, had been preaching at Stockport one Sunday, and met, for the first time, on their way to Manchester in the evening, when the bill became the principal suljeet of conversation. "They both acknowledged," says Mr. Watson's biographer, " that if this bill were to pass into a law, it would be ruinous to the Methodists, and that it would be very injurious in its operation generally." $\Lambda t$ Mr. Jabez Bunting's request, Mr. Watson immediately wrote a letter, which appeared in the Manchester Exchange Herald of May 23rd. In assuming the name of a "Protestant Dissenter," he used that name in its popular sense, as that of one not in immediate connexion with the established church; not that he had any conscientious objections against a rcligious establishment, 
as such, as he distinctly declares, or any scruples as to the lawfulness of uniting in the public services of the Church of England. At that time the dissenters were not duly alive to the erils with which this measure was franght, and a strong statement of the case was deemed necessary to rouse their opposition, Mr. Watson, in this letter, says that the dissenters who, when the bill was first proposed; saw no objection to it, did not know its extent. "They might see little to object in requiring six householders to certify that the person applying for a license was bona fide a preacher, an approved person; but the printed bill materially alters the case, when it requires these six householders to be substantial and reputable persons; for as the terms convey no positive and specifie idea, and as the magistrate alone must judge, where is the security that numberless vexatious exceptions may not be taken, and that the obtaining of a license, especially from a bench of clerical justices, may not become an affair of the utmost trouble and difficulty?" He asks if the insult to dissenters has been the consequence of their quiet submission:" Have we refrained from urging claims, as substantial, surely, as those of the catholics-from teazing the gorernment from year to yearfrom the menace and activity of factious restlessness-only to have our moderation construed into cowardice and tameness ?-only to encourage the enemies of our privileges and the enviers of our growing prosperity to make an experiment upon our patience? And are we to learn from Lord Sidmouth's conduct that the only means of maintaining our lowest privileges is to urge the highest claims with petulance and audacity ?"' Mr. Watson concluded his letter with an earnest exhortation to prompt and manly action. The dissenters throughout the kingdom, the baptists and independents, although they were less directly attacked, joining cordially in the movement, sent shoals of petitions against the measure, and Lord Sidmouth was compelled to abandon it in the stage of second reading. His biographer 
says: "Could he, at an earlier period, have foreseen the opposition which his measure was destined to encounter, he probably would not have proposed it; but being strongly convinced of its propriety, and having received, in the first instance, so much encouragement, he would not, in obedience to a popular outery, withdraw it at the eleventh hour; and for this decision be surely deserved to be approved rather than blamed." $\Lambda$ similar, perhaps conscientious, obstinacy, at a later period, made him the most tyrannical home secretary that crer held office; and he pleaded conscience as carnestly in defending the employment of spies to urge the people to insurrection, as he did in defence of his scheme to make nonconformist ministers " respectable."

Merchants and manufacturers were now learning in the stern school of experience. In the month of $\Lambda$ pril, 1812, in riding past the Manchester Exchange, with my saddlebags under me, I saw a crowd of persons standing looking at that building, the windows of which were broken, a partial boarding supplying the place of glass. I found that the destruction had been the work of a mob a day or two before. I was then in my twenticth year, and, earnestly engaged in $\mathrm{my}$ rocation as a rider or traveller, had taken no particular interest in politics. But on my previous journey, the first I had made, I had seen, with some disgust, the intoleranee of the Chureh-and-King men of Manchester, and in the course of that four months' iourney had foumd that the Birmingham and Manchester bagmen were rated by their fellow-travellers as the rudest and coarsest men on the road. Both towns had earned the inglorious distinction of having attempted to put down opinion by brute violence, and it would seem that coarseness of thought was accompanied by a correspondent coarseness of sentiment and manner. At my inn I soon learned how the riot had oceurred, and how the tables had been turned upon those who had formcrly instigated Chureh-and-King mobs into destructive action. 
In the previous ehapters we have seen that the stern teacher, wdxT, had been amongst the working clisses during the achievement of great national "glory." While they, who had been themselves the willing instruments in the hands of the ruling party at the eommencement of the war, were suffering under the hands of the new teacher, it is not to be supposed that the eommereial classes of Manchester, who had been keen instigators of the insane policy pursued by government, escaped the eonsequenees of their own folly. When weavers were starving, merchants and manufaeturers could not be prosperous. 'The war at the point of the bayonet was accompanied by the war of prohibitions. Napoleon had brought the continent under his yoke; but, to complete this, the eommeree of England must be destroyed. II is great object was to unite the continent in a league against all commereial intercourse with his great rival. Elated with having laid Prussia prostrate at his feet, the first use made of his victory was to issue his Berlin decree, dated the 20th of November, 1806, which deelared the British islands in a state of blockade, all prisoners, wheresoever found, prisoners of war, and all British goods lawful prize; interdieted all correspondenee with our dominions; prohibited all commerce in our produce; and exeluded from the ports of France, and of countries under her control, every vessel, of whatsoever nation, that had touched at a British port. The wise course for England to pursue would have been to leave France and the neutral states, especially the United States of Ameriea, to fight it out among themselves. But the remedy was sought in retaliation. The whigs, who were then in office, set the example of folly to their tory suecessors. On the 7 th of January they issued the first of those orders in couneil which, more efficiently than Napoleon's decrees, conduced to the destruction of English commerce. It declared that the Berlin decree authorized England to blockade all the Freneh dominions, to forbid 
any neutral power from entering our ports which had toucherl at any port of Franee or her dependencies, and justified us in eapturing all her produce; but that we were unvilling to inflict such injuries on neutral nations! The order then declared, as a partial retaliation, that no vessel should trade from one enemy's port to another, or from one port to another of a French ally's coast shut against English ressels; so that, says Lord Brougham in commenting upon the order, the only chance our goods had of being spread orer the continent was by getting them smuggled into some port less watehed by France than the rest, and then their being conveyed from thence in all directions. The only ehanec we had of sending our goods anywhere, was getting them in somewhere, and then having them freely distributed everywhere. "No!" said the ministers of 1807 , "let them be stopped where they are landed, and let no American think of carrying them elsewhere." The tory ministers eame into office in 1808, adopted the whig order, and issued others still more stringent.

The merchants and manufacturers of London, Hull, Manchester, and Iiverpool petitioned parliament against the destruetive poliey of the orders, craved to be heard by their counsel, and tendered evidence of the injuries sustained by them from the operation of those orders. Mr. Brougham was their counsel, and was heard at the bar of both houses, where he likewise adduced the evidence during several weeks, in support of the petitions. The ministry, however, triumphed over all the attempts then made to defent the system; and it was not until four years after, in 1812, that, the general distress having gone on increasing, there was any chance of obtaining a more farourable hearing. In March, 1812, the subject was again brought forward by Mr. Brougham. His motion was then negatived; but, soon after Easter, he presented petitions from the same parties who had formerly been his elients; and on the motion of Lord Stanley, on the 28th of April, 
the house agreed, without a division, to hear evidence in support of the petitions. The case was conducted every night for seven weeks by Mr. Brougham and Mr. Baring. The inquiry on the side of the petitioners was wholly con1ducted by these two members, and each night presented new objections and new defeats to the orders in council, and new advantages to the opposition, by incidental debatings on petitions presented-by discussions arising on evidence tendered-by other matters broached oceasionally in connection with the main subject. The government, at first, conceiving that there was a clamour raised out of doors against their policy, and hoping that this would of itself subside, endeavoured to gain time and put off the evidence. But Brougham and Baring kept stcadily to their purpose, and insisted on calling in their witnesses at the earliest possible hour. They at length prevailed so fur as to have it understood that the hearing should proceed daily at half-past four o'clock, and continue, at the least, till ten, by which means they generally kept it on foot till a much later hour, all but those who took a peculiar interest in the subject having earlier left the house.

The evidence brought before the house was of the most. appalling description. "We have examined," said Mr. Brougham, "above a hundred witnesses, from more than thirty of the great manufacturing and mercantile districts. These men were chosen almost at random, fromr thousands whom we could have brought before you with less trouble than it required to make the selection; the difficulty was to keep back evidence, not to find it; for our desire to state the case was tempered by a natural anxiety to encroach as little as possible on the time of the house, and to expedite by all means the conelusion of an inquiry, upon the result of which so many interests hung in anxious suspense. In all this mass of evidence there was not a single witness who denied or doubted-I beg your pardon; there was one-one solitary and remarkable exception,-and none 
other, even among those called in support of the system, who even hesitated in admitting the dreadful amount of the present distresses. Take, for example, one of our great staples-the hardware, and look to Warwickshire, where it used to flourish. Birmingham and its neighbourhood-a district of thirteen miles round that centre-was formerly but one village; I might say one continned workshop, peopled with about four hundred thousand of the most industrious and skilful of mankind. In what state do you now find that once busy hive of men? Silent, still, and desolate during half the week; during the rest of it, miserably toiling at reduced wages, for a pittance scareely sufficient to maintain animal life in the lowest state of comfort, and at all times swarming with unhappy persons, willing, anxious to work for their lives, but unable to find employment. He must have a stout heart within him who can view such a scene and not shudder. But even this is not all; matters are getting worse and worse; the manufacturers are waiting for your decision; and if that be against them they will instantly yield to their fate, and turn adrift the people whom they still, though inadequately, support with employment."

Yorkshire was in the same state, the manufacture of woollens being almost suspended. At Sheffield, the workmen in the cutlery trade, unable to obtain any longer their usual market, from the master dealers and merehants or brokers refusing to purchase any more, were compelled to pawn their articles at a very low valuation, for money, and even for food and elothes; so that this extraordinary state of things arose, - the pawubrokers went into the London market with the goods, and there met the regular dealers, whom they were able greatly to undersell, in such wise as to supply in a considerable degree the London and other markets, to the extreme augmentation of the distresses already so severely pressing upon this branch of trade.

In Lancashire the distress was, if possible, still mor 
severe. "I would draw your attention," said Mr. Brougham, " to the cotton districts, merely to present one ineidental circumstance which chanced to transpire respecting the distresses of the poor in those parts. The food which now sustains them is of the lowest kind, and of that there is not nearly a sufficient supply; bread, or even potatoes, are now out of the question; the luxuries of animal food, or even milk, they have long ceased to think of. Their looks, as well as their apparel, proclaim the sad change in their situation. One witness tells you it is only necessary to look at their haggard faces, to be satisfied what they are suffering; another says that persons who have recently returned, after an absence of some months from those parts, declared themselves shocked, and unable to recognise the people whom they had left. $\Lambda$ gentleman largely concerned in the cotton trade, to whose respectability ample testimony was borne by an honourable baronet (Sir Robert Peel)-I cannot regularly name him-but in a question relating to the cotton trade it is natural to think of the house of Peel-that gentleman, whose property in part consists of cottages and little pieces of ground let out to work-people, told us that lately he went to look after his rents, and when he entered those dwellings, and found them so miserably altered, so stript of their wonted furniture and other little comforts, - and when he saw their inhabitants sitting down to a seanty dinner of oatmeal and water, their only meal in the four and twenty hours, he could not stand the sight, and eame away unable to ask his rent. Those feelings, so honourable to him, so painful to us who partook of them, were not confined to that respectable witness. We had other sights to endure in that long and dismul inquiry. Masters eame forward to tell us how unhappy it made them to have no more work to give their poor men, beeause all their money, and in some cases their credit too, was already gone in trying to support them Some had involved themselves in cmbarrassments for such 
pious purposes. One, again, would describe his misery at turning off people whom he and his father had employed for many years. Another would say how he dreaded the coming round of Saturday, when he had to pay his hands their reduced wages, incapable of supporting them; how he kept out of their way on that day, and made his foreman pay them. While a third would say that he was afraid to see his people, because he had no longer the means of giving them work, and he knew that they would flock round him and implore to be employed at the lowest wages,- - for something wholly insufficient to feed them."

The inquiry was interrupted by a lamentable event-the assassination of Mr. Percival in the lobby of the House of Commons. The viction of a madman's revenge fell into the arms of Mr. Francis Phillips, of Manchester, a gentleman of whom we shall hear something hereafter as a bitter enemy of reform, and the apologist of the magistracy and of the yeomanry, when a legally convened and peaceably assembled meeting was dispersed by the sword. The intelligenec of Mr. Percival's death reached me at Newcastleunder-Lyne. A man came running down the street, leaping into the air, waving his hat round his head, and shouting with frantic joy, "Percival is shot, hurrah! Percival is shot, hurrah !" The Potteries were in a deplorable state, and oppression, which makes even wise men mad, had roused the savage nature of the half-starved. While, in the renewed inquiry into the operations of the orders in council, evidence daily accumulated of the prevalence of deep distress throughout the country, alike affecting the manufacturer and the operative, the papers tecmed with accounts of the destruction of machinery, and, at times, even of life. The ministry at length yiclded. On the 16th of June, when Mr. Brougham had made his motion to recall the orders, Lord Castlerengh announced that the crown had been advised to rescind them.

The decp distress, of which strong proof had been giren 
before the House of Commons, was not oceasioned by the orders in council alone. By the profuse issues of the bank, no longer checked by the convertibility of its notes, the price of every commodity had risen, except the price of labour; wheat was 15s. 6d. a bushel, and every article of food proportionately high; and the enormous war expenditure had made the pressure of taxation heavy beyond all previous example. The mass of the people, especially in the manufacturing districts, felt themselves as marked out for destruction. They, in their national pugnacity, had eagerly demanded war, and they wcre now enduring its consequences; but a starving are seldom a reasoning people. Ordinary suffering leads to inquiry as to its real cause; but destitution directs attention only to the nearest seeming cause. Few masters could give employment, and none could give good wages; and the unemployed and the illpaid looked upon them as oppressors. The liberal journals had been sileneed by fierce persecution; and newspapers seemed to have no other rocation than to number our splendid victories, to rejoice over the destruction of hundreds of thousands of men who werc called our enemies, and to congratulate the nation on the :great amount of glory which it was achieving.

In the latter months of 1811 disturbanees commenced in the districts of the hosicry manufucture. Many workmen had been discharged in consequence of the badness of trade, and many, as they beliered, in consequence of the introduction of a wide frame for wearing stockings. Leicestershire, Derbyshire, and Nottinghamshirc were first in the manifestation of a fierce and bitter spirit against employers. The actors in the riots assumed the name of Luddites, from an imaginary leader, Captain or King Ludd. In the beginning of 1812 the disturbances extended to Yorkshire, Lancashire, and Cheshire. 


\section{CHAPTER IV.}

DISCONTEXTS AXD SEVERITIES.

Is the beginning of the year 1812, strong expectations had been indulged, that on the termination of the restrietions on the powers of the Regent, he would form an administration not unfarourable to reform. A hypocritical offer of office was made to Lords Grey and Grenville, with the full knowledge that they would refuse to reform any part of a ministry which was established notoriously to resist the emancipation of eatholics from their civil disabilities. They refused the offer made to them, and the Marquis of Wellesley having resigned, the man most obnoxious to popular hatred, Castlerengh, aceepted the seals of foreign secretary, and Sidmouth became home secretary. The leading men of Manchester, untaught by the results of a policy which had been most disastrous to themselves, and had brought ruin and starvation upon their humbler townsmen and fellow-eountrymen, and unaware that reform opinions had been gradually ereeping amongst their own class, ealled a public meeting, to be held on the 8th of $\Lambda$ pril, in the Exehange Dining Room, to send an address of thanks to the regent for retaining his father's ministers in office-those ministers who had involved the world in bloodshed, and subjected their own country to the endurance of misery umexampled. Amongst the names subseribed to the requisition were the following :-

T. Blackburne, LIL.I)., Warden, Collegiate Church.

John Clowes, Fellow of Clurist College.

Jer. Sinith, Head Master of the Free Grammar School.

Thomas Stone, Chetham's Library.

C. W. Ethelston, Fellow of Christ College.

S. Iall, Clerk, St. Peter's Church. 
John Gatliff, Fellow of Christ College.

M. Randall, M.A., Curate of St. Ann's.

J. Clowes, St. John's Church.

Nathaniel Milne, Clerk to the Magistrates.

James Ackers.

T. O. Gill.

Laurence Peel.

Edward Chesshyre.

Thomas Hardman.

Jonathan Beeror.

George Grundy.

Jonathan Dawson.

Francis Phillips.

Thomas Marriott.

James Harrop.

John Leaf.
J. Silrester.

Thomas Johnson.

Robert Peel.

Otho Hulme.

Dauntsey Hulme.

John Hull, M.D.

H. Fielding and Brother.

William Tate.

Robert Hindley.

Samuel Edge.

C. Wheeler and Son.

Nathaniel Gould.

Previous to the day fixed for the meeting, some exertions were made by a few gentlemen of the town to get up an opposition to the passing of the resolutions of approval and thanks which, it was arowed, would then be proposed, and a number of placards were issued calling attention to the subject, and urging the attendance of those who objeeted to the intended morement. These morements seem to have alarmed the persons who conrened the meeting, and they complained of the inflammatory nature of the placards issued, particularly of one headed with the words "Now or never," of which we shall hear something hereafter, when John Edward Taylor is tried at Lancaster for libel. On the morning of the 8th a bill was posted on the walls of the town and neighbourhood, stating that the meeting vould not take place, and the assigned reason was, that the stairease leading to the Exchange dining-room was too weak to sustain the pressure that would be produced by the multitude that had been invited to attend ; but, notwithstanding this announcement, numbers of persons assembled, many of them working men and boys from the eountry, and they very naturally congregated about the Exchange, where, at from nine to ten o'elock, they became a great crowd. 
At this time the parties who had prepared the opposition to the intended proceedings met at the Star Hotel, in Deansgate, and they had to consider what course should be taken under the new circumstances that had arisen. They were in consultation on the subject when information was brought that the people who had been assembled in the Market Place and the area in front of the Exchange had forced their way into the Exchange news-room, and were destroying or damaging the furniture it contained. This news produced considerable alarm in the meeting, and after various suggestions had been made, it was agreed that, in order to aroid all appearance of countenance being given to what had been done at the news-room, the persons then present should immediately disperse, each going away separately as far as was practicable, and this was rather carefully acted on.

"On going towards the Exchange after this time," says my informant, "I found a large asscmblage of persons in St. Ann's-square, and in the news-room a number of boys, who appeared to be enjoying their norel position in the grand room, asking each other to read the papers and tell the news, and pushing each other about towards them, and sceming to think it very good fun. They appeared to be quite harmless, and I will venture to say, that at this period, and even at any time during the first hour, a couple of men might have cleared the room, without any material difficulty, of all who had intruded. I subsequently visited the room more than once, and found the numbers of the country people in it increasing, and no attempt made to remore them. Some of the boys, apparently from a want of occupation, were pulling off each other's hats and throwing them to a distance, to compel the owners to go for them. In the square too the assembled numbers increased, and a man was addressing many of them in the middle of the area. Mr. H. H. Birley, (afterwards to be heard of as heading the yeomanry on the 16th of August, 1819,) in 
passing through the square, was rather roughly jostled, and obliged to take refuge in a shop. Still nothing was done either to satisfy the people or to induce then to disperse. The meeting, it is true, had been countermanded by those who convened it, because the Exchange stairs were weak; but this excuse was laughed at, and treated as a mere pretext, resorted to because the promoters expected to be defeated in their object, if the meeting had taken place."

"Some time after twelre o'clock," continucs my informant, "I went into Salford, and while there heard that the Exchange had been set on fire. I returned immediately to Manchester, and found the windows of the news-room broken and much of the furniture-chairs, tables, maps, \&cc. - destroyed or damaged, and soldiers engaged in driring the crowds from the neighbourhood of the Exchange. But for about three hours large numbers of men and boys were permitted to assemble in the news-room and to resort to various tricks to amuse themselres, until at last, it was said, that a hat, thrown for mere fun, struck one of the windows and broke it; on which, many other parties seemed desirous of achiering the same feat, when a general attack was made and the windows soon destroyed. After. this the demon of misehief seemed to be let loose,- - the chairs, tables, maps, \&c., were attacked, each individual being desirous to destroy as much as possible. But had proper means been used to clear the room beforc trelve o'clock, all serious mischief might have been prevented. As it was, the odium of rioting - of trying to burn the Exchange, \&c. \&e., was thrown on the 'jacobins,' as the opposition party were called. The writer of the placard 'Now or nerer' was particularly censured, and the mischief done was attributed to that document."

Old Thomas Kershaw, in lamenting to me the riot that had taken place, used, chucklingly, to add,--"But we had no Church-and-King mobs after that!" And the gentleman who has kindly acceded to my request, that he would 
write down a few particulars of what he had witnessed on the occasion, concludes his narrative by saying:- "The oceurrences of that day, howerer, indieated a turn in the current of popular opinion. Previously to that time 'Church-and-King' was the favourite ery, and hunting 'Jacobins' safe sport; but subsequently the old dominant party appeared to feel that they had an opposition to contend with, and they became less arrogant in their conduct, although the old leaven was still in them."

A food riot followed. On Saturday, the 18th, a numerous body of people, chiefly women, assembled at the potato market, Shudehill, where the sellers were asking 148. and $15 \mathrm{~s}$. per load (252 lbs.) for potatocs. Some of the women began forcibly to take possession of the articles; but the eivil and military power interposing, all riotous tendency was soon orerawed, and a mutual agreement took place between the buyers and sellers, to fix a sort of maximum, of eight shillings per load, at which they were sold in small portions. On Monday, strong and alarming appearances of rioting took place at Ancoats, and about $\mathrm{Ncw}$ Cross ; a cart earrying fourteen loads of meal was stopped, and the meal carried away; a general alarm followed, and the shops in that part of the town and Oldham-strect were closed. The cavalry were called in, and the multitude continued to assemble till the Riot Aet was read, and the mob dispersed without further injury. The result of fixing a maximum of price, as might have been expected, was, that furmers would not bring potatoes or other provisions to market until the magistrates issued notiecs throughout all the neighbourhood, promising full protection to all who brought farm produce into the town.

The uninstrueted multitude next directed their rengeance against machinery. On Monday: a riotous assembly took place at Middleton. "The weaving factory of Mr. Burton and Sons," says Cowdroy, "had been previously threatened, in consequence of their mode of weaving being done by 
the operation of steam. That afternoon a large body, not less than 2000, commenced an attack, on the discharge of a pistol, which appeared to have been the signal; vollies of stones were thrown, and the windows smashed to atoms; the internal part of the building being guarded, a musket was diseharged in the hope of intimidating and dispersing the assailants; but it was found ineffectual, the throwing of stones continuing, and at the expiration of about fifteen minutes, firing of ball commenced from the factory, and in a very short time the effects were too shockingly seen in the death of three, and, it is said, about ten wounded. Here this horrid conflict terminated for that night, which was spent in dreadful preparation. The morning brought with it fearful apprehension, which apprehension was too fatally realised : the insurgents again assembled, many of them armed with guns, scythes tied to the ends of poles, \&e.; the factory was protected by soldiers, so strongly as to be impregnable to their assault: they then flew to the house of Mr. Emanuel Burton, where they wreaked their rengeanee by setting it on fire, the whole, with its raluable furniture, being soon in one state of conflagration. A party of soldiers, horse and foot, from Manchester, arriving, pursued those misguided people, some of whom made a feeble stand; but here again death was the consequence, five of them being shot, and many of them severely wounded. Two were found in the fields on the following morning, where they had languished and expired from the mortal effeets of their wounds."

It is but just to state that the men whose names have been mentioned, as approving of the policy which had reduced the eountry to so wretehed a state, were foremost in promoting a subseription to relieve the existing distress. Their judgment was too narrow, and their views too contracted, to enable them to trace the general wretchedness to its cause, but their benerolence direeted them to the relief of that part of it which fell under their own eyes. 
They would do nothing to mend the road-they would even persecute all who said the road wanted mending; but they would eonfer their aid and sympathy upon those who had broken down upon the rough and sutty highwey.

On Friday, the 24th of $A$ pril, a large body of weavers and mechanics began to assemble about mid-day, with the avowed intention of destroying the power-looms, together with the whole of the premises, at West Houghton factory. Immediate information was given to the authorities at Bolton, and the Scots Greys were instantly despatched from thence to the scene of riot, a distance of about five miles. On their arrival all was quiet, and no symptoms of disorder whatever appeared; the presence of the military was therefore deemed unnecessary, and the whole force, consequently, returned to Bolton. Scareely had they reached their quarters ere a messenger arrived with the alarming intelligence that the whole factory was in flames. Again the military rode at full speed to West Houghton; and on their arrival were surprised to find that the premises were entirely destroyed, while not an individual could be seen to whom attached any suspicion of having acted a part in this truly dreadful outrage. During the evening, however, a partial assemblage of the most active of the rioters took place in the village, and again alarmed the inhabitants by levying contributions in meat, drink, or money, on some of the more respectable among them. Their audacity appeared to rise with the suceess which attended their lawless demands, and was beginning to develope itself in a more alarming manner, when, nt this eritieal juncture, the arrival of the military put nearly the whole of the nob to flight. A few, however, of the more desperate kept their ground, upon which the riot act was read, and quiet was restored. The whole of the succeeding night was spent in collecting information of the names of those who had rendered themselves eonspicuous by their activity on the occasion, and in securing their persons $i$ 
in consequence of which, twenty-four of them were, early next morning, condueted under military escort to the town of Bolton.

There was reason to beliere that some of the local magistrates had employed spies, who urged on their victims to violenee. Mr. John Edward Taylor, in his reply to a pamphlet published in 1819 by Mr. Francis Phillips, says:- "I have no reason to belicve that the atroeity of the Middleton riots can be palliated by any attempt to prore that the trieks and machinations of hired spies bad any share in producing them. They originated in severe distress, exasperated by a short-sighted prejudice against the introduction of newly-invented maehinery, which the populace fancied was calculated to aggravate the sufferings they were then enduring. The attack of the mob upon the factory, and their destruction of the house of one of its owners, were crimes of the greatest enormity : much, therefore, as the consequences were to be deplored, no. doubts were entertained of the legality of the conduct pursued. However humanity might griere at the death of those who were shot by the military, justice was satisfied. But at West Houghton, where a steam-loon factory was set on fire and burnt down, the case was widely different. This outrage was debated (as appeared by evidenee brought forward on the trials of the rioters) at a meeting whieh took place on Dean Moor, near Bolton, the 9th of April, 1812 , sixteen days before the scheme was put in practice. At this mecting (which was very speedily reduced to numerical insignifieanee by the desertion of a considerable proportion of those who had at first attended it) there were present, during the greater part of its duration, and up to the time of its close, not more than about forty persons, of whom no less than ten or eleren were sPies, reputed to be employed by Colonel Fleteher. On this occension these spies were armed, and disguised with blackened faces. And when some persons wished to retire from the meeting, on 
finding the wicked purpose on which it was bent, they were prevented from doing so by a rear guard, formed chiefly of the armed spies, and marched by force towards West Houghton, where a considerable detachment of military were in ambuscade, awaiting their approach. Upon this oceasion the spies were provided with white caps, to put on when they should come in eontaet with the military, in orler that, being recognised, they might not be hurt. But all the exertions of the spies were insufficient to enable them to carry their plan into effect, The unfortunate victims of their diabolical machinations eould not, at that time, be induced to act; one by one they slunk away from the meeting, till the spies were left alone; so that when a detachment of the local militia, which was sent from Bolton, at midnight, to pick up stragglers, had sueceeded in apprehending a considerable number of supposed Luddites, they were, upon examination, erery man of them, proved to belong to the corps of black-faced spies, and consequently dismissed. The occurrence of eircumstances like these, sixteen days before the burning of the faetory took place, renders it not a matter of presumption, but of absolute certainty, that that alarming outrage might have been prevented, if to prevent it had been the inclination of either the spies or their employers. I am not aware that the truth of the preceding statements, which I have abridged from "Dr. 'Taylor's Letter," and which have now been before the publie seven years, has ever been at all questioned. But, however that may be, I know that proof of then can be given upon oath, to such an extent as must be absolutely decisive of their veracity. At the special commission held at Lancaster, for the trial of the rioters of that periorl, eight persons were capitally convicted. At Chester, though fifteen were condemned to death, two only were ultimately exceuted. But the eonduct pursued at Lancaster formed a striking contrast with this dignificd lenity. There every person convicted, man, 
sooman, and child, were consigned to the hands of the executioner. One of these victins uas a boy so young and childish, that he called on his mother for help at the time of his execution, thinking she had the pover to save him."-

Lord Sidmouth, the new home secretary, gave his hearty approval to this "wholesome" severity. "Wherever the law was clear," says his reverend biographer, "he employed the law to vindieate its own majesty: in other instances, where this was impracticable, he hesitated not to apply to the legislature for the necessary powers to put down erils against which the existing laws provided no adequate remedy." In other words, he availed himself of the laws so far as they suited his cocreive purposes, and if they did not, he applied for new laws to meet the occasion. In Nottinghamshire and Yorkshire destruetive riots had taken plaee, and on the 23rd July he had applied for and obtained a bill for "the preservation of the public peace in the disturbed distriets, and to give additional powers to the justices for the purpose." He corresponded with local magistrates, urging them to proceed rigorously, and promising his support if their zeal should be blamed. He wrote to the lord lieutenant of Yorkshire of the urgent expediency of bringing the prisoners in York Castle for riot immediately to trial, that their eonvietion and punishment, might strike terror into the hearts of the disaffected. A special commission for their trial was opened at York, on the 2nd of January, 1813, and a sufficient number of convictions was obtained to vindicate the supremacy of the law; " and," says his biographer, "it now became the duty of the government to inflict that extensive retribution which the heniousness of the offences, the necessity for a striking example, and the mistaken lenily manifested at a previous assize, had rendered inclispensable; and from this duty, painful as it was, Lord Sidmouth did not shrink. The three murderers (of Mr. Horsfall) expiated their crime at York, on the 9th of January; and on the 16th of the 
same month, fourteen unhappy Luddites, whose cases were considered the most atrocious and unpardonable, were also led to execution-lialf at eleven o'clock in the forenoon, and the remaining seven after an interval of two hours." Lord Sidmouth was highly satisfied with the conduct of all the authorities whose services were required on the occasion. "These severe, but necessary examples," con- tinues Dr. Pellew, "produced a most salutary result in the discontented districts," and he rejoices that the Annual Register has said, that "few years had passed in which more internal tranquillity had been enjoyed by the people of these islands than the ycar 1813 ;" forgetting, however, to state, from the sane volume, that " the bounteous harvest which erowned the hopes of the year, had produced the desirable effect of reducing the prices of the most necessary articles of human subsistence to half, or twothirds of that which they bore during all its early months," and that the low price of food, and the repeal of the Orders in Council, had been accompanied by increased employment and a rise in the price of labour,-cireumstances quite as likely to produce tranquillizing effects as the "extensive retribution" which had been so earnestly recommended by Lords Sidmouth, Ellenborough, Eldon, and Castlereagh. The placid sceretary called his severity benevolence. He harshly punished some, that many might be sared from crime. His mistake was in classing murder, luddism, and radicalism, in the same entegory, and punishing them all alike. Stocking-frame breaking, like corn-law making, was a crime no loubt, but to hang men for it was carrying "retribution" too far, even in the then state of opinion in England. His biographer tells us, that he used frequently to repeat, with approbation, the substance of some obscrvations which the Emperor of Russin made to him. "In England," said his majesty, "where every man enjoys so much freedom of action, the exccution of the laws must necessarily be severe, in 
consequence of the difficulty of imposing adequate restraints on the carly transgression of them. As you cannot, therefore, interpose obstacles to the commission of erime, the only remaining eheck is to punish it severely when committed. In Russia we can interfere to prevent the commission."

The home secretary having, by the help of a good harvest, put down, for a time, the discontent in Lancashire, had leisure to think of benefiting the district in some other way. The reverend Cecil Daniel Wray, then one of the chaplains, now one of the fellows or canons of the Collegiate Church, had pointed out to him the " disproportion between the population of Nanchester and Salford, and the means of accommodation in those towns at places of worship under the established church." In his lordship's reply, dated 20th of November, 1814, he says:- "The eircumstance struck me forcibly when the returns I had moved for were laid before the House of Lords, in 1811; and I urged it, together with many other instances of such a disproportion, as a ground for the interposition of parliament, to correct an evil so farourable to the growth of schism, and, indeed, so injurious to the interests and influence of religion;" and he promises Mr. Wray, that he will call the attention of parliament to the subject, which he did in 1818, snccessfully, as the erection of St. Matthew's, in Camp Field, St. Andrews, in Ancoats, St. George's, in Hulme, and St. Philips, in Salford, prove. In after times, when further extension of ministrations by the rich established ehurch was asked for in Manchester, this same Mr. C. D. Wray, and his fellow canons, resisted any appropriation, for such purpose, of any portion of the funds accruing to the parish church, amounting to some ten thousand pounds a year, and enjoyed by the ministers of that single edifice, who, at the same time, in justification of non-residence, denied that they had the eure of souls. 
While submission was enforced and church extension promised at home, events werc occurring abroad, giving promise to the termination of a war which ought never to hare been commenced, and which brought more miseries in its train than any ever waged. Victories were now hailed, not with savage exultation at the destruction of humian life, but with the hope that erery succeding triumph would bring the nation nearer to the enjoyment, once more, of the blessings of peace. In September, 1812, the French arms was deprived of its winter quarters by the destruction of Moscow by fire. On the 19th of October it commenced its disastrous retreat; on the 5th of December, Napoleon himself left it to its fate; and the campaign was ended in which half a million of lives were sacrificed. In June and July, 1813, the French sustained signal defeats in Spain, and wcre compelled to retreat beyond the Pyrennees. In October the newly-formed army of Napolcon was defeated at Leipsic. On November 2 nd he reached Mentz, with $70,000 \mathrm{men}$, the remains of 300,000 which he bad a few months before led to the Elbe and the Oder. On the 31st of March, 1814, the allies entered Paris; and on the 11th

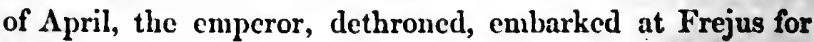
Elba. On the 24th of December peace was concluded between Great Britain and the United States. Once more we were at peace; merchants and manufacturers rejoiced in the expectation of a revival of trade; and the starving rejoiced in the expectation of chcapness and plenty. "The Congress of Vienna had permanently "settled" the affairs of Europe, Castlereagh representing England. Napoleon

- was in his ocean prison, guarded by the French and British flects; and half a century's prosperity was in prospect. Alas, for the vanity of human expectations !

On February 17th, 1815, Mr. Frederick Robinson brought forward his resolutions on the corn trade, to prohibit the importation of wheat when the price was under 808. a quarter. Tumults took place in the metropolis, which 
lasted more than a week, and were only quelled by military force. There were no accounts of battles abroad to divert the people from attention to their own affairs; and affairs looked gloomy enough for a ministry which attempted to lay a heavy tax upon the people's food the moment when the country expected that abundance would follow the reestablishment of peace. Oh for a war to enable the rulers to put the chain on and snap the lock! Opportunely-as opportunely as if it been earefully schemed-Napoleon escaped from Elba, eluded the vigilance of British and French fleets and cruisers, and landed in France on Mareh 1st, only one fortnight after the proposal of Mr. Robinson's resolutions. There was something now to look to abroad. Between the time of Napoleon's landing and the battle of Waterloo, which again "settled" the affairs of Europe, the Corn Bill was passed, not, however, without bloodshedpassed while what was ealled the People's House was surrounded by bristling bayonets-passed to infliet a third of a century's privation on a people exhausted by a twenty-two years' war, and loaded with an enormous debt incurred in the work of destroying human life.

Leaving out of view the loss of more than a million and a half of lives, the derangement of trade, the bankruptey and ruin of merchants and manufacturers, and the misery which had been endured by the industrial classes during threefourths of the war period, let us look at the money cost of this contest. The following exhibits the sums raised by loans and taxes from the commeneement of the war to the peace of Amiens :-

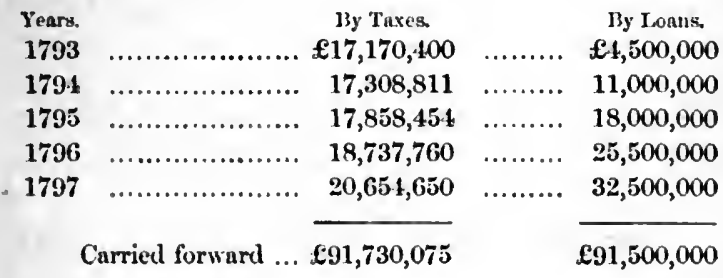




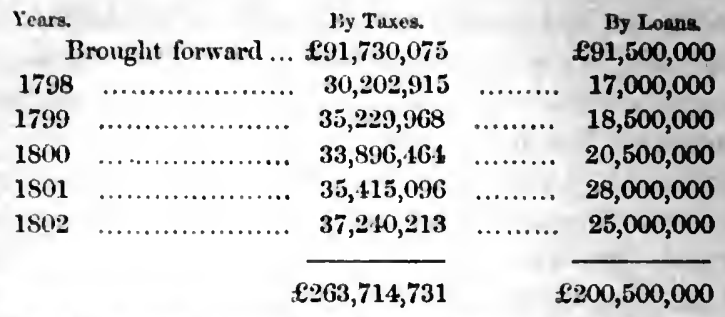

The following exhibits the sums raised by taxes and loans, from the re-commencement of the war to its termination :-

\begin{tabular}{|c|c|c|c|c|}
\hline Years. & & By Tuxes. & & By Lonns. \\
\hline 1803 & & $£ 37,679,063$ & & $£ 15,202,931$ \\
\hline 1804 & ...... & $45,359,442$ & ........... & $20,104,221$ \\
\hline 1805 & ........ & $49,659,281$ & ......... & $27,931,482$ \\
\hline 1806 & & $53,304,254$ & & $20,486,155$ \\
\hline 1807 & & $58,390,225$ & & $23,889,257$ \\
\hline 1508 & & $61,538,207$ & & $20,476,765$ \\
\hline 1809 & & $63,405,294$ & & $23,404,691$ \\
\hline 1810 & ...... & $66,681,366$ & .......... & $22,428,788$ \\
\hline 1811 & ....... & $64,763,870$ & & $27,416,829$ \\
\hline 1812 & ....... & $63,169,85.1$ & & $40,251,689$ \\
\hline 1813 & ..... & $66,925,835$ & ......... & $54,026,822$ \\
\hline 1814 & . & $69,684,192$ & & $47,159,697$ \\
\hline 1815 & … .................. & $70,403,4-42$ & ......... & $46,089,603$ \\
\hline & & & & \\
\hline
\end{tabular}

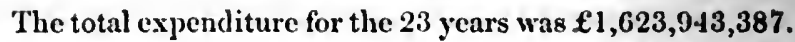
Deducting from this nmount an avernge annual peace expenditure of $f 20,000,000$, the cost of the war was $£ 1,163,943,387$ ! Let it be borne in mind that Manchester, which urged on, with an almost sarage carnestness, that long-protracted and disastrous conflict, was the severest sufferer by its continuance!

Peace, gentle peace and joyous plenty, after long war and long privation! The weary, over-burthened nation was at length to be at rest. But with peace came the com law, to interecpt the free gifts of God to his suffering creatures. We were told we must wait until the eonsequences of 
"revulsion" had ceased ere we could enjoy comfort and abundance; we were told that we must endure the results of a "transition" from war to peace ere we could have prosperity. The fell disease was removed, but we were to take the first steps to health in pain and penury. Were the innocent to be punished with the guilty? Alas! ALI WERE Gurtry. The sin had been a vatroxax sis. The nation had raised its roice and had loudly called for war, demanded war, punished all who were averse to war; and national sin was followed by national punishment; and the instruments of punishment were those rulers who had, nothing loath, been hounded on to war. We had reaped our reward in GIORY; we had earned everlasting FAME in hundreds of battle-fields; - were we to have all that and national prosperity besides?

The war had been undertaken to put down opinion considered to be dangerous to the existence of venerable institutions. When peace was restored, opinion arerse to established abuses again began to manifest itself. "The national joyousness of war," says a historian of the period, " may exceed that of peace, but its joys are more fallacious, if not criminal. It is a period of exertion, of high excitement, in which a conseiousness of internal maladies is forgotten in the death-struggle for foreign mastery. Moreover, it is a season of spending, waste, and reckless prodigality. It is a delirious state-intoxicated by victories, if suecessfulbursting into rage or sinking into despondeney, if defeated. Peace, on the contrary, is less obnoxious to extremes. It is a time of quiet, of reckoning up, saring, and forethought. The smallest evils that exist are felt; all that are impending are imagined and manifold. War affords a ready excuse for every disorder, every public privation, erery remedial postponement; but peace is the ordeal of rulers. Public burdens are nicely weighed, and the pretext for their continuance scrutinized. Not only is the physical condition of the people considered, but their laws, religion, political 
rights, and eren morals, become the eommon topics of investigation. There is leisure for everything, as well as disengaged talent, energy, and enterprise. The troubles and entanglements of peace are mostly the bitter fruits of war; but the glories of war ean only be won by dissipating the blessings peace has aecumulated.

The time of reckoning up, economy, and forethought had come. Passing by the short and fleeting period of a fair reward for labour which the manuficturing populationanongst them the numerous body of Lancashire weaversenjoyed, when the disasters experieneed by the Freneh amnies opened the continental markets to our merchants, and when the plentiful harrest of 1813 had made food abundant and cheap, we come to the period of severe suffering which the self-styled political economists of the ruling party characterised as "a revulsion occasioned by the ehinge from war to peace. The industrial classes had made no caleulation of this painful period of transition; they had thought that when the evil eeased the good would come; they had thought that with peace there would be plenty ; and they had anticipated that they should no longer be ealled from their workshops to raise their voice against misgorerument and oppression. "But," said Mr. John Edward Taylor, writing while his sympathies were yet warm with the suffering multitude, "the giving of a fietitious value to the price of corn, to enable the landed interest to pay the impositions to which it was subjected, was a measure which had produced a deep and lasting irritation in the minds of the labouring classes." The disappointment of their hopes led to deep discontent, entertained for some time in sullen silence, but which, before twelve months had elapsed from the enactment of the corn bill, found articulate, and, to guilty rulers, terrific utterance. Previous to that time, howerer, a small portion of the working classes, sceing the folly of fixing a maximum price for potatoes and a minimum rate for wages, and 
reading attentively the writings of Major Cartwright and William Cobbett, had come to the conclusion that there was no hope for better gorernment unless the people were better represented in the House of Commons. IIad their employers done all they eauld do to prevent the distress and the consequent discontent? 


\section{CIIAPTER V.}

MANCHESTER IN THE FIRST YEAR OF PEACE.

Mr residence in Manchester was the result not of accident, but of deliberate choice, while yet in a position where choice is not often allowed. I had been only two years in a warehouse in Glasgow, when, near the close of the year 1811, my master (a brother of James Grahame, the author of "The Sabbath," and uncle of James Grahame, author of a " History of the United States,") resolved that I should become the traveller in England to receive orders for the muslins he manufactured. My journey extended from Carlisle, through the western counties to Plymouth, and then, through the southern and midland counties, to Newcastle-upon-Tyne. After three years of such employ: ment, another traveller was employed in my stead, and my time was deroted to the wholesale houses of London and Manchester. In Manchester I found that I met in the street, in one day, more country drapers than I could, with the utmost industry, meet in their own shops in two, and it struck me that if we kept our manufactured stock in Manchester, we could considerably increase our business, and at a great saving in travelling expenses. One evening in September, 1815, while sitting with my master at his house, I mentioned the concourse of drapers to Manehester, and expressed my conviction that, if there were to be a continuance of peace, that town would become so much the maket for all kinds of goods, in cotton, woollens, linen, and silk, as to attract every respectable country draper in England several times in the year. The sulject was long and earnestly discussed between us. At length he asked, "Is this a sudden convietion, or lave you thought long about it ?" I told him that every 
recent visit to Manchester had confirmed the opinion I had formed soon after I had been there the first time. I spoke of the coal-fields of Laneashire, and the industry, the enterprise, and the hard-headed shrewdness of its inhabitants. He said, "We have coal, and industry, and shrewdness, and intelligence here." "Yes," I replied, "you hare, but you hare not centrality; you are in a corner; you have nothing but Glasgow and Paisley here; Manchester has about a dozen of Paisleys-Wigan, Preston, Blackburn, Bolton, Bury, Rochdale, Ashton, Stockport, and numerous fast-growing rillages, all increasing in importance, and likely, some time or other, if fair play is given to their industry, to form one enormous community." "But they have the corn-law to retard their prosperity." "So have you." After a long pause, he asked, "When can you go to take a warehouse?" "I would go to-night if there was a coach," I replied, " but I can go by tomorrow's mail." I did go next day, made a bargain for the warehouse No. 1, Peel-street, and in three weeks I opened it with the whole stock transferred from the Glasgow warehouse, with all the responsibility on my young shoulders of, in those days, a large business. It may be supposed I had not much leisure for politics; but I made a point of pushing on work in the early part $o_{\text {. }}$ the day, so that I had the evenings to myself; and I began to look around me to ascertain what was the state of the society in which I was placed, and the opinions which prevailed amongst my fellow-townsmen.

My forefathers, for three generations, had taken the field in defence of the religious freedom of their country, and I had a strong hereditary dislike to church intolerance and exaction; my father had narrowly escaped the prosecution directed against the Scotch patriots in 1794, and I saw, with indignation, the arbitrary stretches of power continued to be exercised by the gorernment; and I had seen the rottenness of both the English and the Scotch 
boroughs, and yearned for parliamentary reform. But the erent which had excited my decpest detestation was the passing of the corn bill. I regarded it, in the first place, as an impious attempt to intercept, for the profit of a few, the gifts which God had bestowed for the benefit of all; in the second place, as an impolitie and impoverishing interference with the liberty of exchanging the surplus produce of our own country for the surplus produce of other lands; and, in the third place, as a gross injustice to the working classes, the great mass of the nation, tending at once to lower their wages and raise the price of food. Such were the opinions I expressed in the spring of that year 1815, to my excellent friend, John Childs, of Bungay, when, at an carly hour of the morning, we were returning through the Strand, after listening to a long protracted debate in the House of Commons during the progress of the corn bill, his memorable reply being, "If we live, we shall see more misery produced by this bill than ever followed human legislation." We have both lived to see the predicted misery. It is something to have lived to be instrumental, even in the slightest degree, in removing the impoverishing infliction. It is something to have been of those who, after an eight years' arduous struggle, destroyed the iniquitous monopoly. It is something for myself to reflect that from 1815, when it was passed, until 1846, when it was prospectively repealed, I never eeased to expose its injustice and mischierous effects. I did not find many persons of my own class in Manchester, whose opinions on free trade in corn were in accordance with my own. The working men, indeed, were right on the question, as they continued to be throughout after struggles; but they were powerless, and could not meet to deliberate without danger to their personal aiberty. The manufacturers had opposed the corn bill, beeause they believed that rising the price of food would raise the wages of labour, and thus 
prerent their competition with the manufacturers of other countries. I found that the opposition to the bill had been very faint. A quiet meeting had been held, pursuant to the following requisition :-

Manchester, Feb. 23, 1815.

To the Boronghreeve and Constables of Manchester and Salford.

We beg you would be pleased to appoint an early public meeting of the inhabitants of the torns of Manchester and Salford, to take into consideration the measures now pending in the House of Commons, relative to the price of eorn, and the propriety of petitioning parliament against the same passing into a law.

Robert Peel,
Phillips and Lee,
John Burton,
James Gordon,
Walker and Bower,
John Bradshaw,
John Potter,
Jer. Fielding,
Wm. Grant and Brothers,
Hargreaves and Dugdale,
Thos. Andrew and Sons,
Andrew Tomlin,
James Heald,
Oakden and Taylor,
J. R. Lamb,
J. Brooke,
James Nieholls,
Jos. Blair,
John Gray,
Jos. Litt,

Thomas Peel,

William. Sandford,

George Fraser,

Thomas Hardman,

James Hibbert,

Peter Ewart,

Joln and Thomas Cooke,

Otho Hulme,

William Tate,

Edward Turner,

William Boyd,

Parker and Co.

Joln Whitehead,

Watkins and Harbottle,

Chadwick, Clogg, and Co.,

Thomas Hollins,

Worthington, Parker, and Co.,

Ben. Sandford,

Brooks and Oughton,

\&c. \&c.

In eomplianee with the abore requisition, we appoint a public meeting of the inhabitants of Manchester and Salford, to be held on Monday evening, the 27 th instant, in the Dining Room of the Exehange Buildings, at eleren o'clock precisely.

H. II. Birtey, Boroughreere,

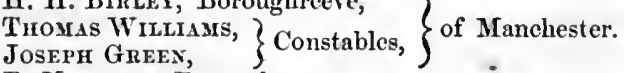

R. Hivdley, Boroughreere,

$\left.\begin{array}{l}\text { RD. Bindloss, } \\ \text { Jown SuERirat, }\end{array}\right\}$ Constables, $\}$ of Salford. 
This Mr. Hugh Hornby Birley, Boroughreeve, who convened an anti-corn-law meeting, presided over it, and signed its resolutions, subsequently attained the bad preeminence of commanding a troop of local yeomanry, which rode furiously, and with newly-sharpened sabres in hand, into the middle of a legally-ealled and peaceably-assembled mecting to petition for the repeal of the eorn-law, striking indiscriminately unarmed men and defenceless women and children. Why, at an interval of little more than four years, did the petitioners of the one period hew down the petitioners of the other? The Birleys and tho Greens, the Bradshaws and the Hardmans, of 1815 , believed that the enactment of the corn-law would raise wages; and the working men of 1819 asked for its repeal because it had reduced wages. The meeting passed the following resolutions :-

"1st. That the great importance of trado and manufacture in this country has been fully evineed during the period of the late war, by enabling us to call forth resources impracticable in any state that was merely agricultural.

" 2 nd. That a large exportation of our manufactures is absolutely necessary to their support, and their sale in foreign markets can be insured only by their superiority and eheapness.

" $3 \mathrm{~d}$. That the great extension of manufactures in France, Switzerland, Germany, and the Netherlands, where they possess decisive advantages from the low price of labour, is sererely felt in this country, and is truly alarning.

" 4 tll. That the proposed restrictions on the importation of corn must materially raise its price, and consequently that of every other species of provisions; and as a great proportion of labour in the manufacture is and must be manual, it will be utterly impossible to earry on eompetition with the Continent for any length of time, if the projected measure be adopted.

"5th. That whilst the landed interest was enriched by the war, the elass of manufacturers sustained, in a vriety of ways, its henriest pressure.

" 6 th. That no policy ean be more short-sighted or unjust, than that which would redress the temporary grierances of a part of the coummunity, by permanently saerifieing the best interests of the whole." 
It will be seen that the stress of these resolutions is upon cheapness of labour as necessary to successful competition with other eountries. The newspapers of the time contain no reports of speeches-no comments on speeches. The notice in Cowdroy's Gazette was confined to the following meagre paragraph :-

"On Monday last, pursuant to a requisition from some of the most respectable mercantilc characters of this town, a public meeting was held at the Exchange Rooms, to take into consideration the propriety of petitioning against the new corn laws, in their process of passing both houses of parliament. Sereral appropriate and spirited resolutions met with unanimous assent, and we hope that the sentiments thus openly declared from so important a trading town as Manchcster, will testify its sense of the impending bill; which, while it may gratify the wishes of interested landholders, must, by its tendency to advance the price of labour, give to the commercial rivalship of other countries a decided pre-eminence."

It appears, however, that there were some who joined in the requisition and attended the meeting who were not satisfied with the resolution laying such stress on the danger of raising the price of labour. I find in Cowdroy an advertisement-and it is a curious sign of the times that they should be inserted only as an advertisement,certain "Plain Observations on the Corn Laws," in the form of resolutions, no doubt intended-very likely by John Shuttleworth, then a rising young man, but not of such standing as to insist very pertinaciously on the unmodified adoption of his views-to be proposed at the meeting, but withdrawn for the sake of committing the old ruling party to an opposition to the proposed act of commercial restriction. From these obriously intended resolutions I select the following:-

"It is evident and notorious that the rent of land has been generally doubled, and in many instances quadrupled, and that erer since the adrance both on its ralue and its product was the result of circumstances, so, or equally, ought both to fall (as is the case in rarious manufactures) when such circumstances cease to operate.

"That the high price of subsistence exceeding what the lower 
orders hare genernlly been able to pay out of their earnings, has greatly contributed to the exeessire poor rates.

"That it is a delusion to hold out to the lower classes, that wages or the price of labour will, or en, rise in the same extent with the proposed rise in the price of food.

"That a great number of persons thrown out of work in all trades, will ineritably reduce the rate of wages.

"That the laborious orders of this empire believing it the effect of a necessary war, hare long sumbitted with exemplary patience to the increased price of provisions, and they must feel with proportionate disappointment, if such now be artificially continued.

"That agrieulture has especially its own protecting duties; that the duties on foreign wines, spirits, and colonial sugars, although generally viewed as a souree of revenue, are not less effectually proteeting duties in farour of the growth of British barley and hops. That these alone outweigh at onee all the protecting dities in favour of manufactures.

"That corn-laws ean be only effectual when accompanied by legislative restriction extended to rent; and as this cannot, perhaps, be practieally enforcel, the free importation of foreign corn ean alone keep down prices.

"That if the threat of laying down more land in grass should be realized, it is not more than seems to be required by the high price of buteher's meat, butter and eheese, as well as bread.

"That the property tax is now about to be repealed, and the cost of the produce of land diminished accordingly.

"That the only equitable increase of rent must be drawn from the incrcase of the quantity of produce, and not from the increase of the price of it.

"That an artificial inerease of rent by parliamentary protections is a depreciation of all other property to the benefit of the landowner.

"That with respect to the labouring elasses, it has been above shown that it is a deception to supposo thcir wages will, or can rise in the same proportion with the proposed rise in the price of foodan expectation disproved by the experience of the late times of high prices, when their increase of wages, howerer, in some places great, did not arert their increased difficulties.

"That it is absolutely neeessary immediate petitions should be presented to both houses of parliament, and the Prince Regent, to prevent the extension of the import price of eorn being altered from 63s. to 80s. per quarter." 
I suppose that, to the open and strong expression of my opinion in preference of the intended resolutions to those which had been passed at the meeting, I was indebted for a call from Mr. Edward Baxter and Mr. John Edward Taylor, afterwards of the Manchester Guardian. Baxter was a man of much energy, whose prosperity in business had not abated his earnestness for reform, and Taylor had a youthful ardour for liberty which promised fair to continue under any circumstanees. Through them I became acquainted with a little cirele of men, faithful, amongst the faithless, to liberal prineiples, who subsequently threw the shield of their protection over the intended rictims of a government oppression, which was, if possible, more vindietive than that of 1794 . There were few remaining of those who had been reformers at the eommeneement of the French revolution. Thomas Walker was dead, and Thomas Cooper had emigrated to America. Ottiwell Wood (father of the present chairman of the board of inland revenue) had removed to Liverpool-out of the river into the cold shower-and Mr. George Philips (afterwards Sir George, Baronet), frightened at the atrocities of the revolution, had retreated into the ranks of the whigs. Robert Philips remained staunch and true to his early principles; his son Mark, afterwards M.P. for Manchester, was then but a lad. Mr. Samuel Greg also remained true to his early prineiples; his son, Robert Hyde, afterwards M.P. for Manehester, had not yet taken part in publie business. And there were Samuel Jaekson, who lived in a house, then in the country, in Prineess-street, Hulme; and Thomas Preston, who lived in a retired villa on the Ashton-road, now a public-house, both venerable and intelligent men; and Thomas Kershaw, William Hazlitt's friend, whose talk was of paintings, and Stringer, of Knutsford, and Chureh-and-King mobs. Of the new men, the earriers-down of reform prineiples to another generation, were J. Edward Taylor, whom I have a lready named; 
Joscph Brotherton, who, then in his country cottage in Oldfield-lane, gare quiet expression to the principles of free trade and peace, which he afterwards boldly asserted in the House of Commons; William Harvey, Brotherton's worthy brother-in-law; Richard Potter, afterwards M.P. for Wigan, benerolent and earnest, then beginning to take a part in public business; Thomas Potter, afterwards Sir Thomas, and first mayor of Manchester, benevolent, strong of purpose, and energetic, always willing to aid the cause of reform, but taking little or no part in public questions ; John Shuttleworth, afterwards alderman, eloquent, intellectual, and bold; and Fenton Robinson Atkinson, an able lawyer and a thorough hater of oppression, whose legal knowledge and earnest love of liberty were soon to be effectively used on behalf of the illegally oppressed. Mr. John Benjamin Smith, now member for the Stirling district of boroughs, making no public appearances, was preparing himself for future labours. Mr. Absalom Watkin, giving himself more to literature than to politics, was, nevertheless, on the way to useful action. Amongst the shopkeepers of reform principles were Mr. John Dracup, Mr. P. 'T. Candelet, and others, who had the confidence of the working elasses, using their influence beneficially. A few more there were, free traders and reformers; but the band, at least among the elass of persons who wore broad eloth and white neckeloths, was small-" a small but determined band," as Richard Potter, referring to the period, used to say, when, in less trying days, the old pioneers in the eause of reform were mentioned with honour. The small band, however, furnished rather a remarkable quota to the legislature, to the press, and to the municipal gorernment of the future borough.

Dr. William C. Taylor, in his "Life and Times of Sir Robert Peel," noticing the first baronet's opposition to the corn law, says:- "It is only justice to observe, that the resistance offered to the imposition of these laws by 
the first Sir Robert Peel, was based upon more legitimate grounds than the demand for their repeal when first raised by the modern manufacturers of Manchester. They took the untenable and unpopular ground that it was necessary to have cheap bread in order to reduce the English rate of wages to the continental level; and so long as they persisted in this blunder, the cause of free trade made but little progress. On the other hand, Sir Robert Peel, with characteristic good sense, had pointed out that these laws were injurious, not to class interests, but to imperial interests. * * * It is absurd to say that Manchester was either the birth-place or the cradle of free trade; it can only claim the merit of reviving the demand for the repeal of an impolitic law, which had been allowed to slumber during a period of great political excitement and some commercial prosperity; and when the revival of the demand took place, it would have been well if the sound principles enunciated by Sir Robert- Peel in 1815, had been unirersally adopted by those who engaged in the new movement."

I came to Manchester soon after the passing of the corn law, and had some part in the origination of the League, and I can safely aver that in 1815 , exclusive of the working elasses, there were not more persons right as to the manner in which wages could be affected by that enactment than there were wrong when the successful agitation of its repeal commenced in 1838 . There were few in 1815 , amongst the rank of merchant or manufacturer, beyond the gentlemen I have named, who held that the high price of food would reduce wages. There were as small a number of those who took any prominent part in the league movement, commencing in 1838 , who held that the high price of food would raise wages. The speech of Mr. John Shuttleworth, at the 1815 meeting, which, for soundness of argument, might have been delivered at the Free Trade Hall in 1845, was not in accordance with 
the opinions of a dozen men of any note in the meeting, and was only tolerated because he was opposed to the bill, as were, though for different and indeed opposite reasons, the great najority of persons present. The energetic eight years' struggle for a total repeal of the corn law. was for the benefit of the whole community-the nerveless and ineffective opposition to the passing of the bill was from a selfish fear on the part of the manufacturers, that their own interests might suffer by an adrance of wages. The schoolmaster had been at work during the interval. Twenty-three years' suffering had greatly sharpened the naturally shrewd intellect of Lancashire; greater mental cultiration had brought higher moral motives into activity; the little band of the year 1815 had been receiving constant accessions to its numbers, constant accessions to its cause. In 1838 the free traders needed only leaders. The time was come-and the men came.

The radical movement was renewed, not eommeneed, in 1816 ; it had its origin in 1812 , but had for a time been repressed, by the same unjust means which had been employed to put down the movement for reform and peace, in which Thomas Walker and his coadjutors had been engaged. I have deseribed the consequences, in that year, of calling a mecting and, at the time when it should have been held, shutting, under a false pretence, the door of the place to which it had been eonvened. The gentlemen who had intended to move the counter-resolutions, did not think it prudent to eonvene another meeting in the then excited state of the publie mind. Some working men, however, probably on the suggestion of the shrewd old John Knight, a manufacturer in a small way, thought it advisable that an opportunity should be afforded to the friends of peace and parliamentary reform to express their sentiments on those suljects, which they conceived to be the two measures most calculated to relieve their present sufferings and prevent the future recurrence of them. It was therefore resolred, 
at a meeting leld on the 26th of May, at the sign of the Elephant, in 'Tib-street, that an address should be presented to the Prince Regent, and a petition to the House of Commons, both of which a committee was appointed to prepare. The resolutions of this meeting appeared in the Statesman newspaper, of the 3rd June, 1812; and another mecting was appointed to be held on Thursday, the 11 th of June, at the same public-house, to determine finally on the prosecution of the address and the petition. When the persons met they were informed that Nadin, the deputyconstable, would attend, with a military force, to break up the assemblage. John Knight said he thought that was improbable, as they were met for a constitutional purpose, and therefore had nothing to fear. 'They did, however, adjourn to the Prince Regent's Arms, Ancoats. "On our arrival," says Knight, in a preface to the report of the subsequent trial, "we were shown into a room capable of accommodating forty or fifty pcople, and after waiting a considerable time, while the company assembled and got some refreshment, we proceeded to business, about a quarter beforc ten o'clock. I began by inquiring the residenees and occupations of the individuals who composed the meeting, and then proceeded to read the resolutions of the 26th of May, and afterwards the address and petition which had been prepared, taking the sense of the company upon each as I proceeded. I afterwards made some observations on the deplorable circumstances of the labouring classes, and lamented and reprobated the conduct some of them had adopted, to avert the continuance of which I recommended frequent and general petitioning, which I endearoured to enforce as the best method of obtaining relief. About this time some person came to inform us that it was eleren o'clock; we then began the financial part of our business, and Mr. Oldham had just laid $f 12$ s. on the table, which I was taking up, when Nadin entered, with a blunderbuss in his hands, followed by a great number of soldiers, with 
their guns and bayonets fixed. Nadin, advancing to the table at which Washington and I sat, inquired for what purpose we were there assembled, on which Washington, handing him a copy of the resolutions, replied, that our object was peace and parliamentary reform. Nadin said, 'I do not belicre you ; that is only a pretence.' He then searched our persons, ordered our names, occupations, and residences to be put down, our hands to be tied, and ourselres to be taken to the New Bailey. I said he surely could not think of preventing us from going home. He showed no warrant, but said we should be examined immediately, as the magistrates were sitting." So firm, shrewd old Johnnot shrewd enough to fear that the legality and constitutionality of his meeting were any protection from the rough hands of Joseph Nadin-was marched off with his thirty: seven compatriots, a gallant guard of soldiers accompanying the manacled men to the prison-house. As these were the first imprisoned of the radicals, I give their names :-

$\begin{array}{ll}\text { William Washington, } & \begin{array}{l}\text { Thomas Cannavan, } \\ \text { Daniel Jevins, }\end{array} \\ \text { James Knigh, } & \text { James Hepworth, } \\ \text { Simon Simmons, } & \text { Robert Slack, } \\ \text { Aaron Marrel, } & \text { Aaron Whitehead, } \\ \text { John Kershaw, } & \text { James Boothby, } \\ \text { John Knight, } & \text { Isaac Birch, } \\ \text { John Godby, } & \text { Thomas Cooke, } \\ \text { Edward M'Ginnes, } & \text { Charles Oldham, } \\ \text { James Lawton, } & \text { Robert Thorneley, } \\ \text { Edmund Newton, } & \text { John Oldham, } \\ \text { John Newton, } & \text { Err Oldham, } \\ \text { James Greenwood, } & \text { Thomas Harsnett, } \\ \text { Thoms Bronghton, } & \text { Joseph Tilney, } \\ \text { Thomas Wilkinson, } & \text { Stephen Harrison, } \\ \text { Charles Woolling, } & \text { Rycroft Heyworth, } \\ \text { William Coppock, } & \text { Randal Judson, } \\ \text { Joln IIowarth, } & \text { James Buekley, } \\ \text { Charles Smith, } & \text { Edward Phillips. }\end{array}$

While the military guarded these poor hands-tied weavers 
on their road to the New Bailey prison, Joseph Nadin earried with him their resolutions, their address to the Prince Regent, and their petition to the House of Commons. The following copy of six of the resolutions will show the nature of the several documents which the deputy-constable carried off so triumphantly :-

"1. That, with the exception of a few individuals, our nominal representatives appear to act under such a baleful influence, as to have ceased to be the effieient guardians of our properties, our liberties, and our lires.

" 2 . That they hare frequently permitted us to be wantonly plunged into unnecessary and ruinous wars, by which we have so far proroked the surrounding nations, as to indueo them to interrupt friendly intercourse with us; and thereby have vastly diminished, if not destroyed, our commerce, and also so enormously inereased our expenditure, that our burthens and prirations are become quite insupportable.

" 3 . That our nominal representatives seem to be so warped by the minister of the day, as to set popular opinion at defianee; so that until the House of Commons is so far reformed as to feel with and speak the sense of the people, the people may expeet to be eoerced into submission.

"4. That it is now acknowledged and deelared by all intelligent and honest men, that our nominal representatives are become so subservient to the minister for the time being, that it is essentially necessary that they be eleeted or appointed by the people at large, to give them firmness suffieient to bccome the real guardians of the people, an objeet essential to our welfare and sceurity.

"5. That so long, intense, and extensive have been the sufferings of the people, that unless a strong hope of speedy deliverance be im. mediately infused int o the publie mind, the most dreadful eonsequenees may bo apprehended; for though liundreds or thousands may be obliged to starve, millions cannot be expeeted to submit to it.

"6. That the only rational ground of lope is in a speedy, radieal, and eflicient reform in the Commons Honse of Parliament; and therefore, as the rational friends of peace and soeial order, we pledge ourselres to use erery constitutional means in our power to obtain so desirable an object, and also engage nerer to cease our efforts till that object be attained."

Of the men in whose possession these resolutions were 
found, and who, with their hands tied, had the honour of a military escort to the New Bailey, twenty-four were put to three others in a loek-up room, where they were confined, nlmost to their suffocation, for sixteen or serenteen hours, without being permitted to sce their friends or their solieitor. On the afternoon of next day (Friday) they were brought before the Rev. W. R. Hay, J. Sylvester, Esq., and Ralph Wright, Esq. (afterwards to be heard of as the Flixton foot-path magristrate), and charged on the oath of NadinNadin alone-with holding an unlawful meeting, and combining for seditious purposes, tending to orerthrow the govermment. Most formidable men these thirty-eight poor weavers! They were again brought before the magistrates on Saturday evening in private, and were told that the charge against them amounted to felony. The "small but determined band," formerly alluded to, had heard of the ease, and Mr. Atkinson, solicitor, had promptly rolunteered his legal assistance. He found admittance to the prisoners on this, their second appearanee, and demanded an immediate examination. Fleming, the spy-witness, gave his evidenee, but the magistrates would not permit him to be cross-examincel. A commitment was made out for the whole thirty-eight, and on the Monday they were sent off to Lancaster Castle, where they were detained prisoners until their trial on the 27 th of August.

The indietment charged William Washington and Thomas Broughton with having, with force and arms, feloniously administered an unlawful oath to Samuel Fleming, and the other prisoners with being present, then and there, with force and arms, feloniously aiding, assisting, and cousenting. Nadin had taken into custody all whom he found in the room, made them all parties in the same charge, no one able to speak for the other, none to be witness for them. It looked black for the prisoners. It happened, however, that Nalin, in his flurry, had passed a man on the landing of the stairease, and that man was fortheoming. Fleming 
swore that the oath was administered to him by Washington and Broughton; but it was prored by several witnesses that Washington was elsewhere at the time swore to, and the man who had eseaped from the elutehes of Nadin swore that no oath was administered at the meeting, and that its only business was to consider about petitioning for reform and peace. Col. Sylvester, in cross-examination, acknowledged that he had given instruetions to Nadin to send Fleming to the meeting, to be asked to be "twisted in," and Nadin acknowledged that he had followed elose upon Fleming to take all the men into custody. Searlett and Brougham were retained by the "small but determined band ;" but in those days no speech was permitted in behalf of persons aeeused of felony, and they could do no better than cross-examine. This was done with effect, and the judge, old Baron Wood, who afterwards tried John Edward Taylor, plainly intimated to the jury that Fleming's evidence was flatly contradieted by ineontrovertible evidence. The prisoners were aequitted. Fleming the spy, was evidently a tool of the magistrates and their coadjutor, Nadin, for he was seen for years about the town, well dressed and seemingly not engaged in any occupation.

The acquittal of John Knight and his thirty-seren compatriots, like the aequittal of 'Thomas Walker and John Horne Tooke, eertainly tended to keep alive some feeling of confidence in trial by jury as a safeguard of personal liberty; but an expensive trial (although the money was found by niddle-class men, towards whom the class of persons from which the prisoners were taken did not manifest much gratitude,) and a long imprisonment previous to trial no doubt operated in the way of intimidation. Thirty-eight men had been taken from their families, kept in prison for nearly three months, and then discharged without a farthing's compensation for their losses and sufferings; glad, however, that they had escaped transportation for life. There were in prospect, for all out-spoken 
reformers, the certainty of incarceration in a miserable dungeon before trial, and the probability of transportation after. Need we be surprised that they felt they were before their time? Need we wonder that some thirtyseven out of the thirty-eight were never more heard of as agitators in the cause of parliamentary reform; and that the mass of the working classes, instead of giving loud utteranee to their embittered feelings, moodily and gloomily waited for more fitting opportunity? Indomitable old John Knight persevered, but quietly; not thrusting himself into danger, but ready to come out, with all his dogged perseverance, when others were ready to come out with him. Four years had old Joln to wait, and then the high price of provisions and the general distress set men a thinking, as he thought, that the evils under which they suffered were irremediable without a full representation of the people in parliament. 


\section{CHAPTER VI.}

THE SECOND YEAR OF PEACE.

Mr. Wheeler, in his History of Manehester," giving an account of the events of 1816 , says: "The period was now approaching, at which Manchester began to be regarded as the centre of wide-spread and deeply-ramified social disorganization." It might have been expected that Manchester and its manufacturing dependencies would first have felt the imporerishing effects of the corn laws of 1815 , which excluded foreign wheat until its price reached $80 \mathrm{~s}$. , and of the greatly defieient harvest of 1816 ; but the discontent produced by the high price of provisions and the consequent seareity of employment was strongly manifested in the agricultural before it openly displayed itself in the manufacturing distriets. It was not at Manchester, Oldham, and Bolton, that riots commeneed, but at Downham, Ely, and Littleport; not at Stockport, Ashton, and Bury, but at Bridport, Biddeford, and Cambridge. Curious commentary this on a law, which, whatever might be its operation on manufactures, was to gire protection and prosperity to agrieulture, and which, sustaining the price of food, was to sustain the wages of agricultural labourers! Strange it is that farm labourers, for whose special welfare the corn law was passed, and so well defended, should, in a single year after its enactment, wage war against their generous protectors, ranging themselves around banners, not inseribed " protection to agriculture," but " bread and blood!" The following account of the Ely riots has been chiefly extraeted from "a plain statement of facts," forwarded to Lord Sidmouth, by the Rev. John Nachell, vicar of Littleport. 
The first disposition to riot manifested itself in the small village of Southery, six miles from Littleport, where a mob assembled on the 18th of May, complaining of want of work, lowness of wages, and dearness of flour. These parties proceeded in a riotous manner to Downham, plundering the butchers' and bakers' shops, and committing various acts of outrage, until a compromise, "very improperly," says the reverend narrator, was made with them by the magistrates, to the effect that labourers should receive two shillings and six pence per day, and have their flour at two shillings and six pence per stone, the regular price at that time being three shillings and nine pence. Nothing farther occurred until the 22nd May, when there were two benefit club dinners at Littleport. In the evening the members, consisting chicfly of labourers, the class of men who, according to the protectionists are always best paid when the price of corn is highest, assembled to the number of two hundred, and with a horn and a banner paraded the village, "committing every excess of plunder and outrage," until about eleven o'clock, when they presented themselves at the parsonage, demanding money. Mr. Nachell's remonstrance as a magistrate, and promises as a minister of the gospel, were equally in vain; his house was foreed open and completely plundered, while the family concealed themselves in the field. Next morning the rioters assembled, in greatly increased numbers, at Ely, where they were joined by a number of disaffected persons." They opened negociations with the magistrates, who felt it advisable to eomply with their terms for good wages and eheap food, and the greater part of the rioters returned to their homes, with a threat, however, of reassembling at night. Meanwhile the Rev. IIenry Law had proceeded express to Lord Sidmouth, and his lordship hearing that the Rev. IIenry B. Dudley, a magistrate of Ely, was in town, sent for him and dispatched him home to preserve its peace. From Cambridge, forty men of 
the Royston troop of volunteer cavalry proceeded to Ely, and finding, on their arrival, that the rioters were still at Littleport, committing "great atrocities" there, it was resolved to surprise them in that place. Eighteen men of the Royals, and part of the Royston yeomanry, headed by the Rev. Sir H. B. Dudley and the Rev. Henry Law, marehed out to the attack, which was completely successful. The first rioter who attempted resistance being instantly shot by a dragoon, the rest made but a fecble resistance, and above serenty of them were taken prisoners to Ely. A special commission was speedily issued to Justices Abbott and Burrough, and E. Christinn, Esq., Chief-justice of Ely, for the trial of the offenders, and the proceedings commenced on the 17 th of June, when thirty-four of them were capitally convicted, of whom five were hanged by the neek until they were dead. Similar disturbanees arose in Downham, Bury, Cambridge, and Norwich, but, " in consequence, probably," says Mr. Sidmouth's biographer, "of the prompt and judicious severity excreised at Ely, were speedily suppressed." "The proceedings at Ely have unquestionably had a good effect," writes Lord Sidmouth himself to his brother; and he resolved to continue the wholesome screrity which had done so much good. There was, howerer, speedy proof teuding to " confirm his anticipations of a winter of discontent and disturbance ;" and Lord Darlington wrote to him from Raby Castle, on the 8th of October, that the "distress in Yorkshire was unprecedented-that there was a total stagnation of the little trade they even had-that wheat was already more than one guinea a bushel, and no old corn in store-that the potato erops had failed-that the harrest was then only beginning, the corn in may parts being still quite grcen, and that he feared a total defalcation of all grain that season from the deluge of rain which had fallen for many weeks, and was still falling." Such were the prospects of the country in the year after the corn law was passed. 
Is it to be wondered at that the disposition to riot which had manifested itself first in the agricultural and then in the coal districts should extend itself to the manufacturing? Repeal the corn law! Restore the heptarchy! The severitics at Ely were regarded as having had " unquestionably a good effect ;" and a continuance of the wholesome severity, with additional enactments to inerease the stringency of the laws, were the only remedies of which Sidmouth, Castlereagh, Vansittart, Lord Palmerston, Mr. Canning, and their colleagues in office, took any thought. Peel, then secretary for Ireland, shared in the difficulties experieneed by the administration to which he was attached. The deficient harrest had greatly aggravated the usual distress of that unhappy country. To the credit of his humanity, and as a presage of the wise policy which he followed in 1846, when matured experience and sagacity had made him more of a statesman, and when he was a dictator to the senate instead of a humble subordinate to the weak and obstinate Sidmouth, he made every exertion in his power to relieve the scarcity, by issuing a treasury order for the admission of American flour free of duty. Let this be remenbered when a statue is erected to his memory in Manehester, to mitigate, in some slight degree, the deep censure justly due to his thirty years' support of the starration-creating monopoly.

Towards the elose of 1816 , the people, disappointed in their expectations that prosperity and plenty would follow in the train of peace, and having no faith in a legislature which, the moment when the war was terminated, had inflicted the corn law, demanded a better representation in parliament. When the Israelites complained of their legrptian task-masters, the reply was-"Ye are idle; yo are idle." When, instead of burning eorn-stacks, and plundering provision slops, after the example of the agrieultural libourers, the manufacturing population demanded reform, the reply was-" Ye are seditious; ye are seditious." 
William Cobbett, then wielding the power of a fourth estate, wrote thus :- " The country, instead of being disturbed, as the truly seditious writers on the side of corruption would fain make us believe, instead of being " irritated" by the agitation of the question of reform, is kept, by the hope which reform holds out to it, in a state of tranquillity wholly unparalleled in the history of the world, under a similar pressure of suffering. Of this fact, the sad seenes at Dundee are a strong and remarkable instance. At the great and populous towns of Norwich, Manchester, Paisley, Glasgow, Wigan, Bolton, Lirerpool, and many others, where the people are suffering in a degree that makes the heart sick within one to think of, they have had their meetings to petition for reform; they have agreed on petitions; hope has been left in their bosoms; they have been inspired with patience and fortitude; and all is tranquil. But at Dundce, where a partial mecting had been held early in Norember, and where a gentleman who mored for reform had been borne down, their violence has broken forth, houses hare been plundered, and property and life exposed to all sort of perils; and this, too, amongst the sober, the sedate, the reflecting, the prudent, the moral people of Scotland." A bad cxample is catching. Riots oceurred at Glasgow, occasioned by discontent with the offensive mode of distributing soup; at Preston, from the weavers being out of employment; at Nottingham, on account of the use of frames; at Birmingham and Walsall, from want of work; and at Merthyr and Tredegar, where, owing to a reduction of wages, 12,000 persons had assembled, and were dispersed by the military. The legislature had sown the whirlwind, and the country was enduring the storm. Indeed, anarchy was averted by the direction of the mind of the oppressed to the remedial measure; but the rulers thought that even the proposal of the remedy was worse than the disease.

"At this time," eays Bamford in his 'Life of a Radical,' "the 
writings of William Cobbett suddenly beeame of great authority; they were read on nearly erery hearth in the manufacturing distriote of South Lancashire, in those of Leicester, Derby, and Nottingham; also in many of the Scottish manufacturing towns. Their influence was speedily vivible. He directed his readers to the true cause of their sufferings-misgovernment, and to its proper correction-parliamentary rcforn. Riots soon became searce, and from that time they have never obtained their aneient rogue with the labourers of this country. Let us not descend to be unjust. Let us not withhold the homage which, with all the faults of William Cobbett, is still due to his great name. Instend of riots and destruction of property, Irampden elubs were now established in many of our large towns and the villages and distriets around them; Cobbett's books were printed in a cheap form ; the labourers read them, and thenceforward became delibernte and systematic in their proceedings. Nor were there wanting men of their own elass to encourage and direct the new converts: the Sunday-sehools of the preeding thirty years had produced unany working men of sufficient talent to become readers, writers, and speakers in the village meet ings for parliamentary reform; some also were found to possess a rude poetie talent, which rendered their effusions popular, and bestowed an additional charm on their assemblages; and by sueh rarious means anxious listeners at firot, and then zealous proselytes, were drawn from the cottages of quiet nooks and dingles to the weekly reading and discourses of the Hampden elubs.

"One of these clubs was established, in 1816, at the small town of Middleton, near Manchester; and I have been instrumental in ito formation, a tolemble reader also, and a rather expert writer, was ehosen secretary. The elub prospered ; the number of its members increased; the funds raised by subscriptions of a penny a week became more than suffieient for all outgoings; and taking a bold step, we soon rentel a chapel which had been giren up by a society of Killamite Methorlists. This place we threw open for the religious worship of all sects and parties, and there we held our meetings on the erenings of Monday and Saturday in each week The proceedings of our society, its place of meeting-singular as being the first place of meeting oceupied by reformers (for so in those days we were termerl), together with the services of religion eonneeted with us, drew a considerable share of public attention to our transactions, and obtained for the lealers some notoricty. Sereral meetings of delegateo from the surrounding districts were held at our chapel, on whieh 
occasions the leading reformers of Lancashire were generally seen together. These were John Knight, of Manchester, eotton manufacturer; William Ogden, of Manchester, letter-press printerafterwards immortalised by Canning, as the 'resered and ruptured Ogden;' William Benbow, of Manchester, shoemaker ; - Bradbury, of Manchester, stonecutter; Charles Walker, of Ashton, weaver; Joseph Watson, of Mossley, clogger; Joseph Ramsden, of Mossley, woollen-weaver; William Nicholson, of Lees, letter-press printer; John Haigh, of Oldham, silk-weaver; Joseph Taylor, of Oldham, hatter; John Kay, of Royton, student in surgery; Robert Pilkinton, of Bury, cotton-weaver; Amos Ogden, of Middleton, silkweaver; Caleb Johnston, of Middleton, cotton-weaver; and Samuel Bamford, of Middleton, silk-weaver. Soon afterwads we were joined by John Johnston, of Manchester, tailor; and Joseph Mitehell, of Lirerpool, draper. Sueh were the eonditions of all whom I recollect as standing prominently forward in thoso times, through eril and through good report, in our district of the country."

In December, 1816, a meeting of delegates was held in the chapel, at which it was resolved to send out missionaries to other towns and villages. William Fitton, of Royton, a very honest and very intelligent man, and Benbow, and Pilkington went to the manufacturing towns in the West Riding of Yorkshire, and were very suceessful in awakening the demand for reform. On the 4th Norember a great meeting was held in St. Peter's Field, Manchester, John Knight in the ehair, "to take into consideration the distressed state of the country;" and similar meetings were held in the meighbouring towns. On the 1st January, 1817 , a meeting of delegates from twenty-one petitioning bodies was held in the Middleton ehapel, when resolutions were passed declaratory of the right of erery male to vote who paid taxes; that males of eighteen should be eligible to vote; that parliaments should be elected annually; that no placeman or pensioner should sit in parliament; that every twenty thousand inhabitants should send a member to the House of Commons; and that talent and virtue were the only qualifieations necessary. "Sueh," says Bamford, "wcre the moderate views and wishes of the reformers in 
those days, as eompared with the present. The ballot was not insisted upon as a matter of reform. Concentrating our whole energy for the obtainment of annual parliaments and universal suffrage, we neither interfered with the House of Lords nor the bench of bishops, nor the working of factories, nor the corn laws, nor the payment of members, tithes nor church rates, nor a seore of other matters which in these days have been pressed forward with the effect of distracting the attention and weakening the exertions of reformers-any one or all of which matters would be more likely to succed with a house of commons on the suffrage we elaimed than with one returned as at present." Mr. Bamford ought to have added, that although the radicals did not petition for a repeal of the corn law, the passing of that act was constantly urged as the strongest proof of the neessity of parliamentary reform, and that at erery public meeting flags were displayed, bearing the inscription of "No corn law."

The encmies of reform were alarmed at the movement of the radicals. On the 13 th of January, at the instigation of Lord Sidmouth, who recommended such demonstrations to be made everywhere, a meeting of the tory party was held in Manchester, to consider the "necessity of adopting additional measures for the maintenance of the public peace." In association to further that object was formed, and a declaration adopted which reeired the signatures of upwards of two thousand of the principal residents. In this cmbodiment of their views and feclings, they stated that " the numerous meetings held, both publicly and secretly - the organised system of committces, delegates, and missionaries - the contributions leried, particularly for disseminating pampletets calculated to mislead and irritate the publie uniud-the indecorous and highly unconstitutional reflections upon the exalted personnge now excreising the royal authority-the marked disparagement of the most extensire charitable relief in the seasons of unaroidable 
pressure-the language of intimidation, not merely hinted, but plainly expressed-the appointment of popular assemblies in various parts of the kingdom on the same day, after the meeting of parliament, and the previous assembling of deputies in London;-all these circumstanees afford strong manifestation of meditated disorder and tumult, and bear no analogy whatever to the fair and legitimate cxercise of that constitutional liberty which is emphatically the birthright and sceurity of Englishmen." Meetings for the same purpose were held at Bury, Bolton, Rochdale, Oldham, Stockport, Ashton, Saddleworth, Sandbach, Congleton, and Liverpool. On the 25th of February an attempt was made, by holding a meeting at Preston, to cheek the progress of "disloyalty" in Lancashire, but the " loyalists" were outvoted and defeated in their objects. Other means had to be tried.

An assault on the Prince Regent, upon his return from opening the session of parliament in January, came opportunely to aid the operations of the terrorists. Soon after a message was sent to both houses, communicating to them "papers containing information respecting certain practices, meetings, and combinations in the metropolis and in the different parts of the kingdom, evidently calculated to endanger the public tranquillity, to alienate the affeetions of his majesty's subjects from his majesty's persou and government, and to bring into hatred and contempt the whole system of our laws and constitution." These papers were referred to select committees in both houses; and in both, these committees reported that there was a dangerous and wide-spread conspiracy for the subversion of public order. Sidmouth was ready with his remedies. In his estimation sererity was mercy, and radicalism was as bad as frame-breaking Luddism, and little less atrocious than the murder which was expiated by the executions at York in 1812. Bills were at once introdueed for suspending the Habeas Corpus Aet-preventing the seditious meetings- 
punishing attempts to seduee soldiers or sailors from their allegiance-and providing for the seeurity of the royal person. They were earried with but slight oppositionparliament thus declaring that it needed no reform, and that it would not permit the subject to be diseussed.

Evil advisers had erept into the ranks of the radieals, and spies and ineiters to misehief had been sent amongst them; and then eame the "Blanket Meeting," in St. Peter's Fields, Manchester, afterwards to become still more celebrated in the annals of radicalism, from which thousands of men were to mareh to London with their petition, eaeh earrying a blanket or rug strapped to his shoulder, under whieh he was to birouac on the road, if no better aceommodation could be had. Mr. John Elward 'Paylor says that Mitchell had the eredit of inventing this rather unusual mode of exercising the constitutional right of petition. Mr. Bamford says: "It was one of the bad schemes whieh aceompanied us from London, and was the result of the intercourse of some of tl.e deputies with the leaders of the London operatives-the Watsons, Prestons, and Hoopers. Mitehell and Benbow had cultivated a rather elose aequaintanee with these men, little suspeeting, I have no doubt, that their new friends had already fallen under the influenee of instigators who betrayed all their transactions to the government." Bamford says he protested strongly against the projeet; but his warnings, if he did warn, were disregarded. On the 10 th of March the meeting was held, and several hundred persons set out on their route to London. Some time after their departure, a considerable detachment of the King's Drageon Guards rode rapidly up to the hustings, whieh they surrounded, taking those who were upon them, twenty-nine in number, amongst whom were Baguley and Drummond, into custorly. "Benbow," says Bamford, "took eare not to make his appearance." 'The meeting was then dispersed by the troops. "Ilere, however," says Mr. J. E. Taylor, in the pamphlet from which I have formerly quoted, " is to be 
found the precedent for that novel form of reading the Riot Act (if in either ease it were read at all), which was followed on the 16th of August, 1819. The aet was certainly not read according to the mode prescribed by the statute, nor were the crowd allowed that time for dispersion, which the law gives them." When the field was eleared, a large body of soldicrs and constables were despatched after those who had proceeded on the road towards London. They came up with them on Lancashire Hill, near Stockport. Some hundreds were taken into custody, several received sabre wounds, and one industrious cottager, resident on the spot, was shot dead by the pistol of a dragoon, at whom a stone was thrown from the situation where, with others, the poor man stood. In this ease a verdiet of "Wilful nurder" was returned by the coroner's jury, but no steps were taken to bring the delinquent to justice. "Trifling as was the general amount of injury sustained on this oecasion," says Mr. Taylor, "I have the means of stating, positively, that this circumstanee was owing, rather to the humanity and coolness of the military, than of the magistrates and municipal officers. Sir John Bing repcatedly found it necessary to check the violenec and impetuosity of the civil authorities." About a hundred and eighty persisted in their mareh, and reaehed Maeelesfield at nine o'eloek, of whom some lay out all night, and found their way home next morning, and some were committed to prison. About fifty went on to Leek, and only some twenty were known to have gone as far as Ashbourne, some of whom found their way to Derby, stopping where the Scotch rebels stopped in 1745 .

After the deseription of the "blanket" folly, and after quoting Bainford's assertion that the plan was brought from London by Mitchell and Benbow, subsequent to the meeting of deputies of the Crown and Anehor, on February 7 th, it is but fair to state, that Mitehell says that the plan was agreed upon at Major Cartwright's long before that 
time, in the presence of $\mathrm{Mr}$. Cobbett, who fully approved of it, and of Mr. Peter Walker, who did not dissent. - It is not of much consequenee accurately to know who where the originators of the folly. It brought much misery upon many misled men, and no little discredit on the cause of parliamentary reform thus attempted to be promoted.

The blanket meeting and the blanket march were, of all possible devices, the least likely to convinee the middle and the aristocratic classes that the multitudes were fitted for the enjoyment of the electoral franchise; and yet there were cireumstanees which, though not amounting to a justification of those movements, offer, when duly considered, some palliation of the folly. There were many brought to the rery brink of starvation-and hunger seldom reasons; there were many of those who thought that the open exhibition of their misery would excite sympathy and bring relief; and there were many who thought that the show of strength, without being illegally put forth, would ensure respect to their claim for fair representation, In smaller numbers were those who thought that it would be patriotic to achieve, even by force, if force were to be used against themselves, the rights which were denied them; and there were some who, being employed by government and the local magistracy to discover sedition and betray the seditious, made work for themselves by instigating the disaffected into such open action as would make then amenable to the laws. Bamford tells of having been waited upon by a young man, a stranger, and invited to take part in making a "Moscow of Manchester;" and how, in the belief that he was only misguided, the fellow was permitted to go away in safety after the atrocious proposal had been made!

There had been unnecessary severity in dispersing and pursuing the people who had met and, blanket-enveloped, marched. Middle-elass men, then themselves becoming reformers, severely blamed the harsh dispersion and the rough pursuit. There neeled to be some justification for 
the past harshness, and some reason for the continuance of eoercion. On the 28th of March the magistrates and people of Manchester, in constant correspondence with Sidmouth, notified " that information had reached them, on which they could place the fullest reliance of a most daring and traitorous conspiracy, the object of which was nothing less than open insurrection and rebellion." They added, that "deputies, calling themselres delegates, not only from the principal towns in this district, but others from a considerable distanee, are known to be engaged in it. The town of Manchester is one of the first pointed out for attack, and the moment fixed upon for the diabolical enterprise is the night of Sunday next, the 13th instant." The awful plot is more circumstantially described in the report of the secret committee of the House of Lords : "It was on the night of the 30th of March, that a general insurrection was intended to commence at Manchester. The magistrates were to be seized, the prisoners were to be liberated, the soldiers were either to be surprised in their barracks, or a certain number of factories were to be set on fire, for the purpose of drawing the soldiers out of their barracks, of which a party, stationed near them for that purpose, were to take possession, with a riew of seizing the magazine. The signal for the commencement of these proceedings was to be the firing of a rocket, or rockets; and hopes were held out that 2,000 or 3,000 men would be suffieient to accomplish the first object, and that the insurgents would be 50,000 strong in the morning."

"The official promulgation of these statesmen," says Mr. Wheeler, "eombined with the scenes which were enacting through the country, excited much apprehension. The provisions of the Watch and Ward Act were put in force in Manchester; special constables in large numbers were enrolled, troops poured in from all quarters, and, in conformity with the recommendation of the grand jury of the sessions, three troops of yeomanry, each containing fifty 
men, were formed. It was believed that a conspiracy had been organised for a simultaneous rising throughout Lancashire, Derbyshire, Staffordshire, Yorkshire, and Warwickshire; and no body can doubt that there prevailed amongst the people much dissatisfaction, arising in great part, probably, from commereial distress, as well as from political discontent." I had to take my part in these watehings and wardings, and I recollect that one night after I had headed a company, amongst whom was Mr. Johu Edward Taylor, who lived next door to me in Islington-street, Salford, I wrote in the minute book at the station-house that I had found all quiet during our domiciliary visits, and my belief that the lieges would remain quiet if they were let alone. We shall hear of the yeomanry corps, at that time formed, hereafter, when they achicred an unenviable fame. What became of the great plot so circumstantially described, and giving rise to such precautions for the preservation of the king's peace?

On the erening of the 27 th of March, 1817, about a dozen persons were taken into custody at $\Lambda$ rdwiek and other parts of the town, and sent, not to the New Bailey prison for committal to take their open trial at Laneaster, but to London, to undergo secret examinations at the home secretary's office. $\Lambda$ fter the first burst of astonishment and alarm, which this intelligence caused, had subsided, people began to inquire a little into the probability of their being well founded, particularly as the 30th of March had passed without the slightest discernable symptom of popular efferreseenec. In order, probably, to arrest the current of public incredulity, the Rev. W. R. Hay, stipendiary chairmain of the bench of magistrates, in his charge to the grand jury at the Salford sessions, as reported in Wheeler's Manchester Chronicle of the 26th of $A$ pril, stated, that when the trials of the parties accused came on, "purposes of the blackest enormity nust be diselosed to the publie," and that those "who mrofessed to doubt their existence, would be finally 
constrained to admit the existence of the whole of them." But, notwithstanding this positive official assurance, all the persons arrested on the imputation of these atrocious designs were discharged, not only without trial, but without any indictment being ever preferred against them:

Two spres had been taken into custody along with the men who were apprehended as implicated in the plot, but they were immediately diseharged. One of them had assumed the name of Warren, but his real name was Waddington, and his place of residence Bolton. The other was a man named Lomax, a barber at Bank Top, Manchester. It was denied in parliament that the latter was a spy:- but he was elosely connected with Waddington, whose title to the epithet was nerer disputed, and his instant release showed what his occupation had been. It was further admitted that he had written to Lord Sidmouth on the 17th of March, offering to become a spy. Michael Hall, another spy, who assumed the name of Dewhurst, was in the house at Ardwick when the alleged conspirators were arrested, but it was arranged that he should. escape. After Waddington's exposure in the House of Commons, he was passing through a street in Bolton, when a young man, a schoolmaster, exclaimed, " $\mathrm{Oh}$, thou blackface!" a term there in use, sinee the riot at West Houghton, to designate a spy. Waddington coolly lowered his gun, fired, and sent a ball through the thigh of his unfortunate accuser! He was eommitted to prison for this offence, but Colonel Fletcher, or Major Watkin, immediately ordered him to be discharged on bait, although the offence charged was unbailable; and in the meantime it was managed that the poor schoolmaster should be indicted at the Salford sessions for a riot, Waddington being the principal witness against him. He was eonricted, and on his subsequently obtaining liberty he was unable to prosecute his own charge against Waddington, who went unpunished! I have reason to know that a gentleman then in office at Bolton, much disgusted at this 
perrersion of justice, was induced to inquire on what foundation his tory opinions had been laid, and that the result was his conversion to reform principles. Nor was this an infrequent result of similar obserration and inquiry.

Amongst the persons taken into custody, under the suspension of the habeas corpus aet, in connection with this pretended plot, was the weaver poet, Samuel Bamford, who was apprehended and handcuffed at Middleton, by Nadin, the deputy-constable of Manehester, and six or eight police offieers, all of whom were well armed with staves, pistols, and blunderbusses. Nadin is thus described by Bamford :"He was, I should suppose, about six feet one ineh in height, with an uncommon breadth and solidity of frame. He was also as wcll as he was strongly built, upright in gait and active in motion. His head was full sized, his complexion sallow, his hair dark and slightly grey; his fentures were broad and non-intelleetual, his language coarse and illiterate, and his manner rude and overbearing to equals or inferiors." The radical poet, who seems, after all, to have had no dislike to this rough deputy, gives a specimen of his eonversation on their way to the New Bailey prison in Manchester :-

"Passing Street Bridge and Royley, we entered the rillage of Royton, the streets of which were deserted and the doors shut. We soon returned to Royley, and the constables made a dash into a house in seareh of a man named Meller, but he was not there. A erowd was collected near the earringe, and as I was expeeting to move on, the door wis suddenly opened, and a long, thin barrel of a human boly was thrust into the coach, head first, a couple of stiltlike legs being doubled up after it. 'Lock 'em together,' said Mr. Nadin, and it was no sooner said than done. This person had met some of the runners in a back court or alley, and threatened to beat in their brains with a walling hammer which he had in his hand. "

"George Ilowarth, for that was the name of my new companion, was a decent, labouring, marriel man, of Royton, and was about six feet four inehes in height. He said he thought it a very hard case; 'he cudno' tell wot he'd dun amiss.' Mr. Nadin said he'd know 'wot he'd dun amiss' before he was mueh older. 
"'Why, bless your life, Mesthur Nadin,' said George, 'yo're a graidley felley for out 'at I kno' to th' contrary, an' I never sed nowt ogen yo' i' my lyve.'

'“ 'Aye, an' I'll make thee into a graidley felley too afore I ha' dun wi' the. Theaw'rt a moderate length to begin wi', but theaw'll be lunger afore theaw comes back to Reighton: ween ha' the hang'd,' said our keeper.

"'Nay, Mesthur Nadin,' sail George, 'dunno' say so : they axt wot I had i' mi' hont, an' I shode 'em; it wur nobbut a bit or a wallin' hommer 'at I'd bin a borroin'.'

"' Aye,' said Mr. Nadin, 'an' theaw sed theaw'd knock their brains eawt' wi' it. But ween larn thee, an' aw yo' jacobins, heaw yo' threatun to kill th' king's officers : theaw'll be hang'd as sure as theaw sits theer.' George seemed thoughtful upon this. He looked at the shackles, and at me; and soon after we drew up at the Spread Eagle public-house, in Manchester-street, Oldham."

On Sunday, the 30th of March, Bamford, along with Dr. Healey, Joseph Sellers, Nathan Hulton, John Roberts, Edward Ridings, and Edward O'Connor were sent off to London, heavily ironed by the legs. Nadin wished to add body and neck eollars, and armlets with ehains, but the king's messengers objected to their use. The prisoners were aceompanied by the two messengers, and Joseph Mills and James Platt, Manchester police officers. On Tuesday they were conveyed to the secretary of state's office, at Whitehall, where they were received by Sir Nathaniel Conant, the police magistrate, Sir Samuel Shepherd, the attorney general, Lord Sidmouth, and Lord Castlerenghthe seeret tribunal, which, under the suspension of the habeas corpus act, superseded judge and jury. On the 29 th of April, Bamford appeared for the fifth time at the home office, and was discharged, giving his personal bond in the sum of one hundred pounds, to be levied on his goods and ehattels, if within twelve months he did not appear in his majesty's court of justice at Westminster. The other prisoners were sent to various places of eonfinement, but were all ultimately disnissed untried, although many of them were eharged with being deeply implieated in the F 2 
terrific Ardwick plot. Poor Bamford, huffed and euffed and ironed at Manchester, was greatly mollified by the official civility of Lord Sidmouth, and records his "warmest gratitude" to Mr. Williums, the messenger, to whose care he had been consigned, and who, on the morning of Bamford s release, male him "a handsome present of clothes."

And so ended this grand plot, and so were fulfilled the predietions of the Rer. W. K. Hay, in his charge to the grand jury, that when the trials of the parties accused came on. "purposes of the blackest enormity must be diselosed to the publie," and then those "who professed to doubt their existence would be finally constrained to admit the existence of the whole system!" It requires a great stretch of charity to think that the reverend magistrate had any belief in the existence of the plot. I do not believe he had; but the confident predietion served the purposes of the Sidmouth administration, and, for such and further services in repressing the demand for reform, the reverend lawyer, a few years afterwarts, was rewarted with the vicarage of Rochdale, worth $£ 2,100$ a year.

Not contented with the suspension of the Irabens Corpus Act, which cnabled ministers to imprison, and to hold in prison, any one suspected of radicalism, Lord Sidmouth desired to lay the press at his feet. On the 12th of May he addressed a cirenlar to the lords lientenant of England and Wales, apprising them that the law offieers of the crown had given an opinion that the magistrates possessed the power of holding to bail persons found selling writings which were deemed, though not legally adjudiented, seditious or blasphemous libels, and requesting that they would notify the same to the respective justices within their juriscliction. Farl Grey brought the matter before the House of Lords, ly moving "that the case submitted to the law officers be laid before the louse ;" but his motion was rejected by a great majority. A similar motion was made. in the House of Commons by Samuel Romilly, and with 
the same result. The expression of opinion, however, had been strong enough to deter ministers from their purpose. A short time before the publieation of Lord Sidmouth's circular, William Cobbett had sailed for America, mueh to the indignation of some of the radicals, who thought he ought to have shared with them the risk of imprisonment. No doubt he feared that a movement against the press, by an unconstitutional stretch of power, was contemplated, and that it would be made to apply especially to him. The following was his farewell address :-

"Liverpool, 26th Mareh, 1817.

" My departure for America will surprise noboly but those who do not reflect. $\Lambda$ full and explicit statement of my reasons will appear in a few days, probably on the 5 th of April. In the meanwhile I think it necessary for me to make known that I lave fully empowered a gentleman of respectability and integrity to settle all my affairs in England. I owe my countrymen most sincere regard, which I shall always entertain toward them in a higher degree than towards any other people upon earth. I eary nothing from my country but my wife and my ehildren, and surely they are my own, at any rate. I shall always love England better than any other country. I will never become a subject or eitizen of any other state; but I and mine were not born under a gorernment haring the absolute power to imprison us at its pleasure; and, if we can avoid it, we will neither live nor die under such an order of things. If I have not taken leave of numerous friends in London and in the eountry, it was because I should hare been made unhappy by their importunities and the expressions of their sorrow. I make an enormous sacrifiee of property and of feeling; but, when my heart feels the tugs of friendship, and of all the interesting objeets in Hampshire, it is reconeiled to the loss by the thonght, that $I$ can enjoy them ouly during the pleasure of a secretary of state. When this order of things shall cease to exist, the'n shall I again see Eugland.

\section{" WILLIAM COBBETT."}

If there was little of heroism in this retreat, nothing could be more cowardly than the procecdings of the ministry. With all its irresponsible power, the constitutional safeguard of personal hiberty heing suspended, it did not dare to touch the hair of the head of any man beyoud 
the station of an operative cotton spinner, a weaver, or a common day labourer. These were the elasses amongst whom the spies were sent; from these classes were taken the men who were sent to dungeons, to be afterwards discharged without trial. The administration of 1794 boldly proceeded against Thomas Walker, who had been boroughreeve, and held high mereantile station. The administration in the spring of 1817 was bold enough to apprehend a few dozens of poor, friendless, and nameless men, but it had not the courage to bring them to trial. Orert aets were wanting, and it set to work to make them. If nen would not rise in open rebellion to give ministers an opportunity of exereising "wholesome severities" on a grent scale, misereants, assuming the name and expressing the feelings of reformers, were to be sent amongst them, to irritate their discontents, and to assure them that if they would only rise, with arms in their hands, there were tens of thousands ready to join them, and to strike a decisive blow for their liberties! 


\section{CHAPTER VII.}

THE SPIES EFFECTUALLY AT WORK.

Mrsisters finding that they could not bring into open court the parties charged with being concerned in the awful plot which was to have made a " Moscow" of Manchester on the 30th of March, 1817; seeing that their prosecution of Thomas Jonathan Wooler, for a libel upon themselves, was abortive; and knowing that on the trial, for a riot in London, in December of the previous year, of Watson, Thistlewood, Preston, and Hooper, which was fixed for June 9th, they had not a particle of evidence to support the charge of high treason beyond what could be supplied by Castles, an infamous spy in their own employment, became exceedingly anxious to obtaiu a further suspension of the Habeas Corpus Act. On Friday, the 13th of June, Lord Sidmouth brought before the House of Lords his bill for that purpose. On the previous day the report of the secret committee had been read to the house, and although two months had elapsed from the time at which the Ardwick plot was to have exploded, and no evidence had been found against the parties implicated, the particulars of that alleged revolutionary scheme were stated as fully and as particularly as if every allegation could be positively and irrefragably proved. The report stated also that in some part of the proceedings there were "traces of an intention to issue proclamations, absolving the king's subjects from their allegiance, and denouncing death against their opponents." With a strange candour it was added, "The committee, howerer, allow that they have not found any evidence of the preparation of these proclamations." On averments such as this the legislature was asked further to suspend 
the law for ensuring the liberties of the subject. The bill was read a second time on Monday, 16th, and on Thursday, 19 th, it was read a third time and passed.

No time was lost in carrying it to the lower house. On the following day the report of the sceret committee of the commons was read, and, like that of the lords, the main stress was laid upon the Ardwick plot, ministers then well knowing, if they did not well know from the first, that there was not a particle of evidence that it ever existed. On Monday, the 23rd, Lord Castlereagh proposed the first reading of the bill. Strong representations had gone from men of respectuble station in Manchester against belief in statements which had been framed by persons known to have been employed by govermment, and known also to have urged the discontented to some overt treasonnble or seditious act. In allusion to these representations, and to the ehiarge that a miscreant named Oliver, a gorernment spy, hatd, in many places in Lancashire, been endenvouring to excite to treasunable practices, Castlereagh said that Mr. Oliver had not gone on his government mission till the 17 th of April; that two dangerous plots had been concocted before that time; and that "it was not an inproper thing to send him down to see rchat was going on." Money, he said, was constitutionally placed at the disposal of government for such purposes, and it was not right that its agents should be maligned. Mr. Ponsonly; a member of the secret committee, said : "IIe opposed the bill, as not called for by the danger, which miglit be remedied by other means. He had asked Oliver, in the committee, various questions as to the sort of persons implieated in these proceedings, when Oliver had distinetly avowed, that he knew of no persons of rank or influence who were eomected with the agitators. IIe moreover admitted that he knew of no society in London who were acting with them in the country. Yet Oliver went into the country as the London delegate, was received as such, and told the people that London was ready 
to rise on the first movement, though it would not begin first. Such information must have had the effect of stimulating the wretched manufacturers to acts of rebellion, in the hope that a change would relieve them from their distresses. As no person of rank or influence was engaged in these morements, it was quite unnecessary to suspend the liberties of the whole nation on account of the disturbances in a few districts. Such measures would never restore tranquillity."

A member rejoieing in the name of Lee Keck saw no cure but in the suspension of the law; for so long as the free agency of the leaders was allowed, nothing would put them down; such agents as Oliver, a man "of good moral character," were absolutely necessary. Mr. Abercrombie, afterwards Speaker, could not understand the morality which gained confidence on purpose to betray, and incited to action on purpose to destroy. It is lamentable to find the name of Wilberforce supporting Castlereagh on this occasion. He supported the measure because he did not believe that Lord Sidmouth would abuse the powers bestowed upon him under the suspension of a constitutional law. He would yield reluctantly for the sake of the poor, and on account of the turbulence and irreligion of the times! Lord Althorp retorted upon Wilberforee, that to give such confidence to ministers was the sure way to destroy the best safeguards of the constitution. Romilly also protested against $\mathrm{Mr}$. -Wilberforce's course. He said : "It was now for the first time arowed that spies were in the regular pay of ministers, and were apart of the eruel system of administration. Was not this enough to excite general discontent and disgust? Government carefully avoided bringing persons to trial. Did not this prove they were afraid of investigation? These measures of repression, as they were called, had manifestly inereased the mischief. Day after day, encroachments were making on liberty, on the plea that power would be placed in gentle hands. He would entrust such 
power in no hands, least of all in those of men who had refused to give the names of those whom they had imprisoned. Was his honourable friend (Mr. Wilberforee) in the house when a petition was presented from an individual who had been seven years in confinement under a former suspension? There were many such cases. An opinion pretty generally prevailed that ministers resorted to these measures of alarm for the purpose of getting rid of questions of economy and maintaining themselves in place."

Brougham, still in his early might, ridiculed with much effect the resurrectionary plot. He said: "As to the discontents, were there no laws to check them? However mild, pure, and inoffensive the disposition of the noble secretary, it should be recollected that he was the recorded dupe of the informer Oliver. Who was to give security that the secretary might not be made the tool of a band of informers, whom he had collected round his office, and who were daily filling his ears with tales of terror, of sedition, and rebellion? Much had been said of the employment of spies, and of their respectability and morality! Was it nothing that Oliver had fraudulently used the names of others to win a confidenec for the purpose of abusing it, and that for hire? Was it nothing that he was a cheat, in faet, and a murderer in contemplation? Was it nothing that he would have been responsible for every drop of blood shed on that scaftold to which he would hare led his blind and miserable victims? The other side of the house seemed to have strange notions of morality! Could a more blackened villain be found than one who went about to ensnare that he might betray, and to corrupt that he might destroy?"

Mr. Canning, whose better days had not come, lent himself to the encroachment on the liberty of the subject. The house, he said, should recolleet that the mob of Paris had pillaged the palaces of kings; ho would defend the noble lord who had been so harshly attacked; of all men the noble lord was the fittest to be entrusted with such 
power. Lord Folkstone, the present Earl Radnor, who in both houses has always been a thoroughly independent member, said :- " He could not refrain from smiling at the honourable gentleman's defence of the noble seeretary, remembering, as he well did, the unsparing ridicule with which he had himself assailed the same distinguished personage. (Hear, hear.) Who but recolleeted the poor doctor-a creature, the diagnosis of whose characteristie infirmity had so often amused the right hon. gentleman!

"The symptoms, a dulness that sits in the head, And dislike to all changes of place."

Whether in prose or in poctry, the great object of his derision, and that, too, for want of talent. Now, he was the fittest person in the land to be entrusted with power, though he was, of all men, the most easily to be duped and misled."

All was unarailing. Two hundred and seventy-six voted for the bill; only one hundred and eleven against it. On the following day the second reading was carried by eighty votes against thirty. On Friday the 27 th, the bill was read a third time and passed. Ministers had the power, until the 1st of March, to imprison anybody whom they suspected or professed to suspect. Oliver was again let loose on the country. Castles had been irretrievably damaged by his unsupported, and, as the jury beliered, false evidence against Watson, who, after a seven days' trial had been acquitted. But Mr. Oliver was a man of "good moral character," according to Mr. Lee Keek, and so he was let loose upon the country to betray and destroy.

Bamford, in his "Life of a Radieal," says, that soon after his return from imprisonment, without trial, in London, he found that a seeret " influence" had been at work, exciting to and earrying on private meetings and suspicious intrigues, and that a well-dressed and apparently well-off stranger had been the chief mover. One day an old man, whom Bamford recognised as an old co-delegate, named Bacon, 
from Derby, called upon him, accompanicd by " a decentlooking young man, mueh like a town's weaver." The old man told of a great meeting to be held in Yorkshire, which would give a finishing stroke to the borongh-mongers. He seems to have been communicative on further designs, for Bamford says he advised his informant not to attempt to overthrow, by force, a national order of things. Bacon said he was too old a politician to be counselled by one so young as Bamford; and so the old man "drank his beer rather hastily, and took himself off with his company." "Reader," says Bamford, " this pertinacious old man was, in a few days after, arraigned for high trenson at Derby, and pleading guilty was, with fourteen others, transported for life; whilst the young man, who was one of the Turners, was hung and beheaded, with the equally unfortunate Brandreth and Ludlam." * * * "That strangerthat betrayer-reader, was OrIven THE SPy."

Oliver excited an insurrection in Derbyshire; he could do nothing in Lancashire. There was " $a$ small band" of men in Manchester, not named, not even remotely alluded to, in Bamford's history - some of them, however, named by $m e$ in a previous chapter-a band receiving, in 1817, accessions of persons led to think about the question of reform from the tyrannical proceedings of government,-who had traced the workings of espionage, and denounced the betrayers. We-for I had the honour of belonging to the body-had never been approached by the spies. They did not dare. Their instructions were to go among the nameless and the friendless. But they had ineffectually attempted to tamper with men who held a middle station between us and the working classes. Our warnings-the warnings of men whose proteetion of the oppressed inspired confidence-land spread widely; and the native shrewdness of our Sunday-school-instructed population did not rest. Even hot-headed, unreasoning fools, who were disposed to have recourse to physical force, were distrusted as the tools 
of government. We had raised the ery, "beware of spies," and it sared Laneashire from the follies eommitted in Derbyshire and Nottinghamshire, in 1817, and also from participation in the spy-instigated rising in Seotland three years afterwards. We had begun, besides, to write in Cowdroy's paper, previously containing, like the other local papers, little that was not gleaned from the London journals. Cowdroy, a stout-hearted honest man, was glad of the assistance we rendered him, and bravely encountered the risk of giving utterance to opinions most unpalateable to the powers that then were. We somewhat restrained the expression of our thoughts in order that he might not be prosecuted by the government; for though we could have borne him harmless, so far as expenses were coneerned, we could not guarantee him against imprisonment.' I sometimes said to him - "Are you not afraid, Cowdroy, of being indicted for seditious libels?" "Not I," was the usual reply: "write away." The following passages from an article in his paper, of November 1st, 1817, on the termina. tion of the special commission at Derby, will show that Manchester was beginning to enjoy the advantages of a free press :-

"It was necessary to prove that the arm of the law is strong enough promptly to arrest and properly to punish the actors in such daring outrages, some of whom scem to hare felt no hesitation in adding to their other enormous guilt the deeper crime of coll-blooded and unprovoked murder. Yet it is perhiaps of material consequence to the publie to endeavour to ascertain the nature, by investigating the origin, of the transactions to which we have referred; for, considering the proceedings of the 9 th of June as a 'lecying war against the king,' they assume an aspect which $f$ seems impossible to regard as otherwise than supremely ludicrous. What are the facts as to the conmencement of the affair, as far as they appear upon the eriflence? Why, that the plot was laid in an obseure public-house one Sunday forenoon, in an assembly fluctuating between the numbers of half a dozen and twenty individuals, in the presence of tico special constables, who, after eautioning the assembled traitors to 'mind schat 
they acere saying, and informing them of the high authority with which they were themselves inrested, were actually deterred, even subsequent to the breaking up of the meeting, from giving any information to the neiglabouring magistrates, by the terrible and appalling threat of being 'put up the chimney'!!!

"There are a number of assertions sworn to have been made by Brandreth and other leaders in these tumults which it seems impossible rationally to aceount for, even upon their own views and feelings, in any other manuer than by supposing that they were themselves ceceived by some prior agent, in order that they might be more effectually instrumental in the deception of others. We allude to the information which this general-in-chief eommunicated to his army, that 'all England, Scolland, and Ireland would rise that day;'-to the assertion of Barnes, that 'the keys of the Tower of London were given up to the Hampden Club;'- to the statement of Weightman, that 'Nottingham had been taken by storm;'-and again of Brandreth, that 'a great cloud was coming from the north', which it would be impossible to resist. These rery expressions are so exactly like those of Mr. Olirer, that, coupling them with the notorious fact of this respectuble agent of government having been in the neighbourhood of Derby about the time the insurrection took place, it is impossible not to conelude that he had a great share in producing it. Indeed this fact was distinetly asserted both by Mr. Cross and Mr. Denman, and we do not find that it was controverted by any of the crown lawyers. Government haring learnt wisdom by the fate of Castles, very prulently kept Mr. Oliver ont of sight, and it was probably impossible for the agents of the prisoners to find him. Besides, he would of course have declined answering any questions which might tend to criminate himself, and no proof of his guilt could lessen the legal responsibility of those who might, in truth, baro been his rictims. Yet it does seem strange that his name and agency were not more prominently insisted on.

"But if it be said that the object of Brandreth and Weightman was to encourage their adherents, we reply that the opposite disheartening effect would be nuch strongtr when the falsehood of their statements was discovered. This, indeed, was soon and strikingly exemplified on their approach towards Nottingham, where the whole rebel army fled in the utmost disorder, at the approach of-one magistrate and one dragoon ! $\$$ !

"We cannot think it possible that Brandreth would knowingly hare deroted himself and his followers to absolute and infallible 
destruetion. He must have been taught to expect very different support from what he found; and by whom wero these expectations created in his mind, if not by Mr. Oliver?

"The whole eitizens of Nottingham experienced none of the horrors of a bombardment; the keys of the tower remained in the custody of his majesty's lieutenant; and though 'great elouds' might 'come from tho north' nothing else came. That Mr. Oliver should hold out expectations of support from this neighbourhood is the more probable, because we know, notwithstanding the fact has never yet appeared in print, that this 'moral' person was extremely active in his endearours to implicate some of our own townsmen in his villainous designs, that he was partieularly solieitous that Manchester should hare sent a 'deputy' to the eelebrated meeting at Thornhill Lees, and that when he failed in his earnest entreaties to induce one gentleman to whom he applied to attend there, he most anxiously sought to obtain from him a reeommendation to some other person, who might probably be induced to go."

The gentleman who was so earnestly entreated to attend the meeting was Mr. Nicholas Whitworth. The person to whom Oliver was so desirous to be recommended was Mr. P. T. Candelet, then an ardent young reformer. The spy did not venture to tell Mr. Whitworth of plots and risings. He was too cunning for that. He talked of a legal mecting, attended by respectable deputies from all parts of the north of England, for a determined but eonstitutional purpose. Had Mr. Whitworth consented, under these deceptive representations, to attend the meeting, it would have been instantly bruited abroad that the reformers amongst the merchants and manufacturers of Manchester were making common cause with the working elasses, and had appointed a deputy for that purpose. Mr. Whitworth was too shrewd a judge of eharacter to be deceived by the plausible government agent, declared lie would have nothing to do with him, and having warned Mr. Candelet to be on his guard, that gentleman declined to have any communication with Oliver, who had sought an interview through another medium.

Nearly twenty years after the trials" at Derby, it was 
- represented to me that some of the persons then transported were still living in banishment. Mr. Denman, one of their counsel, had been promoted to the judicial bench. He knew that the men lad been instigated to their folly by spies cmployed by government. Many of the whig ministers had, while in opposition, denounced the system of espionage as abominable and wicked. I thought the period was farourable for an application on behalf of the so long expatriated. To the eredit of the ministry, thanks to Brotherton, Philips, Gisborne, and other members of parliament, who took the matter up warmly, it was successful. Many had been banished who were hut slightly implicated in the so-called insurrection. They had pleaded guilty because they saw that the farmers on the Derbyshire juries, anxious to get home to their harvest work, were determined to convict. They preferred banishment to exceution. One sentenced to transportation for life was a lad of eighteen years of age, who, for his boyish offence, was punisled by exile for more than eighteen years.

Party spirit was not much less virulent in 1817 than it had been in 1794. I have mentioned that, in the former period, a purcly literary association in Liverpool, of which William Roscoe, Dr. Shepherd, and Dr. Currie were members, had considered it prudent to suspend its social meetings in consequence of the persecuting spirit of the times. A similar association existed in Manehester, which, in addition to literary subjects, discussed questions of political economy, and, of consequence, sometimes trenched upon the grounds of general "politics." I have had occasion more than once to notice that the Sidmouth administration had not, like the Pitt administration, the courage to direct their prosecutions against men holding the stations of Joln Horne Tooke and Thomas Walker; but with feeble hand, wielding enormous and uneonstitutional powers, contented itself with entrapping and perseeuting such men as John Knight and Samuel Bamford. The members of our 
Eiterary Society were safe individually; but we did not feel that we were safe as an association. The courts gave a strange interpretation to the word "conspiracy;" and that whieh might be uttered with perfect impunity by the individual, was ruled to be wicked, and seditious, and treasonable when two or three met to "breathe together." We had Jeremy Bentham's assurance that judge-made law, on this subject, was not the law of the land; but we had to consider that, in the event of a trial, we should have to encounter the law as interpreted by the judges. Like the Roscoe Club in Lirerpool, we agreed to suspend the meetings of our society, and to diseuss questions of literature and political economy by our own firesides. We heard now and then of the outward tory world from one of our number-the only one who resorted to the places where our opponents loved to congregate and recrente - of insult and contumely heaped upon him because he was a reformer. We had one advantage over the reformers of 1794. Commerce had largely extended, in spite of all the trammels with which it had been loaded; and the commereial spirit had begun to mitigate the virulence of party spirit. Thomas Walker had deeply suffered in his business by the conspiracy against him; but the field had become too wide for a similar operation against us. Shuttleworth and Taylor could sell their cotton to men who could not buy it cheaper elsewhere. In like manner, Thomas and Riehard Potter could sell their fustians, Brotherton and Harrey their yarns, Baxter his ginghams and shirtings, and I my fine Glasgow nuslins.

And yet our position was uneomfortable. We were safe ourselves, but every clay brought us report of wrong and outrage done to our humble fellow countrymenwrong and outrage which we felt we could not fully redress. We thought, in our own checrful homes, of the poor men in prison for alleged political offences-the main offence being that they, like ourselves, were of upinion 
that our representative system was susceptible of amendment. The whole aspect of society was unfavourable. The rich secmed banded together to deny the possession of political rights; and the poor scemed to be banding themselves together in an implacable hatred to their employers, who were regarded as their cruel oppressors. Out of this bitter antagonism there seemed to be no other result than some great and destructive convulsion. Many were my aspirations-

" $O$ for a lodge in some rast wilderness,

Somo boundless eontiguity of sluade,

Where rumours of oppression and deceit

Can near reach us more!"

Some of the younger amongst us, like Southey and Coleridge at an earlier period, formed the design of ereating a society of our own, in one of the western free states of the American union. It was proposed that ten or twelve, possessing moderate capital, should obtain a tract of land in Ohio, lying along some stream running into a navigable river; that none should possess individually more than a section of six hundred and forty acres, in order that we might not be too widely spred for mutual co-operation and friendly association; that the same quantity of land for each should be bought as a joint-stock company, to be disposed of in smaller portions, with the consent of the community, to millers, blacksmiths, joiners, and persons of like useful occupations who might be disposed to join us; and that we should give our aid and assistance to enable intelligent and industrious farm-servants to emigrate to our colony. It was a pleasant dream, this imagination of a tract some fifty or sixty miles in length by four in breadth gradually filling up with intelligent men, enjoying the rude plenty of the new world with the civilazation of the old! Ourselves sitting under our own vines and our own fig-trees, planted with our own hands, surveying our golden wheat waving on land turned up by our own hard labour or 
directing care, and offering an asylum, amongst us and around us to the oppressed of our native land! I went over the very ground in 1848, and on the banks of the beautiful Little Miami River, deseribed to John Brooks, my fellow-traveller, our feelings and the reasons why our intentions were not earried out. There was the pain of tearing ourselves from the land of our fathers; and there were the hope, and something like the faith, that truthful principles might yet prevail; and there were the whisperings of conscience that something was required to be done at home before it was abandoned-that the seed should be sown before we had a right to expect the harvest. The design was not formally relinquished. It was cherished as that which might be carried into execution were there no indications of amendment in the mother country. The erents of 1819 showed that there was some fructification of the seed that had been sown, and revired the hopes of the previously almost despairing.

A coercive repression of the public utterance of opinion often tends to facilitate its quiet private adoption and progress. Reform prineiples made considerable advanees during the suspension of the Habeas Corpus Aet. Bamford confesses that the noisiest of the radical orators were sileneed; and as the loudest were usually the most foolish, the reproach of their folly was, for the time, removed from the eause which they so injudiciously adrocated; and soberly-thinking working men began to long for the time when they could join in a rational morement for the attainment of some share in the enaetment of the laws which they were bound to obey. In the forced silence of the mere trading demagogues-many of them men who would rather harangue from the platform than ply the shuttle-the middle classes could calmly think of their own exclusion from political rights, and on the results of defective representation, as shown in the wretched legislation and tyrannical proceedings of a "borough-1nongering" government. 
When that tyramy was exercised with still less regard to law and to constitutional right,-when a legally-convened and pencefully-held meeting was exposed to the sabres of a body of yeomanry, eager to obey the impulses of their own heated tempers and their hutred of all reform, - and when magistrates who directed the sanguimmy attack received the thanks of royalty, -it was seen in the wide and deep expressions of indignation, that the principles of rational roform had macle great progress during the time between the blanket meeting of March, 1817, and the great St. Peter's Field meeting of August, 1819.

Amongst the quiet but effective labourers for the produetion of thought had been the Sunday-school-teachers. Earnest to impart religious and moral instruction, they had been awaliening powers of thought amongst the rising gencration which might have linin dormant and useless, or, otherwise directed, have become mischierons and destructive. There, in their upper rooms, Sunday after Sunday, year after year, sacrifieing the ease and confort of their own days of rest, did they, in the discharge of an imperative religious duty, toil on untiredly, in the full faith that the breal thus cast upon the waters would be seen after many days. If there is to be any hero-worship, let it be paid to those patient, unregarded, unrewarded, unknown, often much rlespised workers in the over-crowled. stifling garret, or the dark under-ground sehool-room. With the single underiating purpose of promoting the eternal welfare of their pupils, they were preparing then for the fit discharge of their social and political duties. They were creating ruovent umongst the hitherto unthinking masses. From amongat those teachers were to arise men to earn. by their well-directed inlustry and the exeellene of their character, a higher position in society, and the oplortumities of higher usefulness-in civie authority, and even in the senate; whilst in the lowest classes was introduced a leaven which, if not extinguished by state interference, or by 
spiritual wickedness in high places, promises to leaven the whole mass. To this voluntary labour, unpaid labour, hearen-directed but deepised labour-quiet, unostentatious, almost unseen-is mainly owing our exemption from sanguinary rerolution; and to the continuance of such labour must still be mainly owing what we have yet to gain in the recognition and practical operation of the great principles of internal government, and external friendly intercourse with the family of man.

In the comparative lull of political agitation, a warm discussion took place in the Manchester papers about the exportation of cotton yarn. "An old manufacturer," who was, I believe, Mr. Rateliffe, of Stockport, in long and frequent letters, earnestly warned the Manehester public of the distress that would accrue from allowing foreigners to purchase our twist. He took it for granted that what was not exported would be woven up at home, and henee it was easy to calculate how many additional weavers might thus be employed. Tens of thousands of looms might be set to work, with all their adjunets of winders and warpers, by a single stroke of the legislative pen. How oppressive and tyrannical it was to eut off the source of all this profitable employment! And then there were other men writing in the papers against permitting foreigners to settle in Manchester, and, by buying goods direct from the manufaeturers, taking the bread out of the mouths of our own nativo merchants. It was asserted that there were some foreigners who were so impudent as to buy, not finished goods-that would not have been so very bacl-but fustians in the grey, and having them cut, dyed, and dressed themselves. Nay, there were some of our merchants who were. bold enough to assert, that unless an end was put to this invasion of native privilege, we might have foreigners actually beeming manufaeturers here! Poor Rnteliffe was assailed unmercifully by a set of young writers in Couclroy, who quoted Adam Smith against him. I made rough work with the 
book authorities. I quoted not only Adam Smith and Josiah Child, but all the other political economists, English and French, whose works $I$ had cittrer read or read of, and triumphantly asked whether their fantastic theories were to be set against the practical knowledge of Mr. Ratclifie, the "old manufacturer" of Stockport? He was impervious both to argument and ridieule. He honestly believed that he was right; but finding that the publie would not believe with him, he bethought him that if we could weave by steam, we should beat the foreign weavers, and work up all our yarn at home. The great difficulty was how to dress warps so as to admit of continuous working in the loom, and that difficulty he set himself to overcome. He succeeded, and met the usual reward of ingenious inventors; he introdnced a new mode of production, and it produced nothing to himsclf. He was a public benefactor, and was laughed at as a visionary sehemer.

During that lull of political agitation we had also much talk about the theory that population increases in a greater ratio than the increase of the means of subsistence, and many, out-Malthusing Malthus, began to speculate about the evil of supporting paupers who, Nature's table being already full, ought rather to be allowed to die off! Some of our whigs who had "ratted" from their reform principles, on the pretenee that they had been shocked by the atrocities of the French revolution, were the foremost and eagerest in the promulgation of these opinions; and there were indications of a movement, even in the face of the corn-law and enormous taxation, for the total abolition of legal relief to the poor. The Scoteh eould do without poor-laws, or with poor-laws allowed to go into disuctude, and why might not we? Dr. Chalmers eaught at this cry, and in an article in the Edmburgh Review, on the "Causes and Cure of Pauperism," adranced the doctrine, that a legal provision for the poor increased the poverty it professed to relieve. I had previously seen the necessity, not of abolishing the 
Scotch poor-laws, but of rigidly enforcing them upon a landed proprietary which, drawing large rents, contributed nothing to the relief of poverty. Having seen in Lanarkshire an old man of eighty toiling his way, up to his knees in snow, to my brother's house, I asked him why he did not stay at home and be relieved by his parish. He said, "Ah, sir! they gie me a shilling a week, and that disna keep me, and I canna help coming out to beg." I found, on inquiry, that by the compulsion of seen distress aeting on benevolence, my brother paid more in relieving wandering beggars -beggars sent out because they might be starred to death at home-than I paid in poor-rates on my warehouse in Manchester, which happened to be of just the same rent as he paid for his farm. In my "Letters from Scotland," written in the summer of 1816 , and purporting to be from the pen of "An English Commercial Traveller," I had indignantly denounced the heartless system; and when I found that the doctrines of Dr. Chalmers, its apologist and abettor, were eagerly adopted by certain classes in Manchester, I employed Cowdroy's press in printing a pamphlet in reply to his article in the Edinburgh Review, relentlessly exposing its fallaeies,- - for which I was heartily abused, in Glasgow especially, where good old women and good young ladies said that nobody but an atheist could oppose any opinions held by Dr. Chalmers. My pamphlet was only a stone thrown into the strong stream, but the ripple it caused was seen by others able to throw stronger impediments into the current.

In this year, 1817, the history of which we are now passing, there occurred an astounding instance of the indifference of the inhabitants of Manchester to an important public right. There bad long been a wooden bridge, free to all foot passengers, eonnecting Manehester with Salford, of very great convenience to erowds of working people, who had to pass to their meals or their work sereral times a day, from the one township to the other. A number 
of gentlemen met and resolred, that instead of the old wooden bridge there should be a handsome stone one thrown over the Irwell ; and very great was the laudation poured out upon them for their public'spirit. A jointstock company was formed, and an act of parliament was obtained, giving powers to take down the old bridge; but iustead of a elause retaining the long-established publie right, there was onc empowering the collection of the toll of a halfpenny from erery foot passenger!. It is said that, in after years, when the clause was pointed out to Lord Shaftesbury, he remarked that if his attention had been directed to it at the time, he would have struck it out, even although no one had appeared to protest against it. Charity leads to the supposition that when the gentlemen, so mueh lauded for their improring spirit, had erected a handsome bridge, with commodious approaches, they thought they lad established a right to exact the halfpeuny; but very few regretted that the speculation was profitless. The bridge and its approaches, within some two hundred yards of the Exehange, had remained a desert for thirty years. The full tide of human existenee which flowed down Market-street had, for all that time, been suddenly. arrested there. The speculators had lost eriery farthing of money they adranced. Even those who lent money on mortgage, unable to obtain anything like the usual rate of interest, were glad at last to aceept a composition, raised by subscription, that the ancient right might be restored. In 1848 the bridge was thrown open to the public. Of old persons there were numbers who, in passing once more free orer the inky" stream, said, exultingly, "Well, those who took our right away one-and-thirty years ago, have not made much of it anyhow." We shall hear, hereafter, of provision being made against similar encroachments on public rights, of Vegetable Wright and his Flixton footpath case, and of sundry inroads resisted by the society for the preservation of ancient footways on the secluded privacy 
sought to be acquired by the exclusion of the unwashed multitudes from pleasant field roads, their own unalienable property. Are these trifles beneath the notice of the historian? The vindication of a right in small things keeps alive the spirit of resistance to greater unjust encroachments; and the man who preserves a footway where the humble mechanic can take his wife and children through fresh and verdant fields is as much a bencfactor as he who gives to the public a park or an arboretum. The assertion of ancient rights of footways in Manchester led to the establishment of additional sources of enjoyment to the industrial classes. A gencrous subscription of $£ 30,000$, a few ycars ago, put threc parks, of thirty acres each, into the possession of the public; and to these places of recreation, as well laid out as the grounds near a nobleman's mansion, the humblest of our population have free access, injuriously touching nothing and destroying nothing, but proving that the poor will be conservative, even of beauty, when confidingly trusted. 


\section{CHAPTER VIII.}

I N DEN NTY TO MINISTERS.

THE Regent, in his speech on the meeting of parliament, 27th January, 1818, having assured the two houses that the confidenee he had invariably felt in the stability of our national prosperity had not been disappointed, said- The improvement which has taken place in almost every branch of our domestic industry, and the present state of publie credit, afford abundant proof that the difficulties under which the country was labouring were chiefly to be ascribed to temporary causes." He went on to say : "So important a change could not fail to withdraw from the disaffected the principal means by which they had availed themselves for the purpose of fomenting a spirit of discontent, which unhappily lead to insurrection nnd treason; and his royal highness entertains the most confident expectation, thit the state of peace and tranquillity to which the country is now restored, will be manifested against all attempt to disturb it, by the persevering vigilance of the magistracy, and by the loyalty and good sense of the people." The Earl of Liverpool in the lords, and Castlereagh in the commons, in reply to questions from Lord Holland and Lord Althorp, announeed the intention of ministers to bring in a bill for the repeal of the act for suspending the operation of the Ilabeas Corpus Aet. As it was well known that this was to be followed by an act of indemnity for all the illegal and oppressive measures that were resorted to during that suspension, a meeting of some of the leading reformers in Manchester was held, at which it was resolved that a petition should be addressed to the Ilouse of Commons, declaring the falsehood of the allegn- 
tions on which the Habeas Corpus Act was suspended. The following is a copy of the petition :-

"That the petitioners heard, with great pain and uneasiness, the alarming statements which were currently circulated during the early part of the past year, as to the evil designs entertained by the labouring classes in their neighbourhood, and eoncealed under the disguise of an anxiety to obtain a reform in the representation of the people; that the petitioners lave found themselves obliged to conclude that the impression produced by the statements to which they have now referred, greatly influenced the decision of the house in concurring with the proposals of his majesty's ministers, cntirely to suspend some, and materially to abridge other of the most raluable rights and privileges which Englishmen derive from the bravery and wisdom of their ancestore, and which afford their best safeguards against the enerachments of arbitrary power and the abuses of intolerant party spirit; that, although firmly conrinced, at the period when those measures were proposed by his majesty's ministers to the considerntion of the house, that the circumstances of the times did not require, and that constitutional rigilance could not acquiesce in the suspension of the act of Habeas Corpus, and the other encroachments adopted by the house, the petitioners thought it most proper to defer the expression of thcir sentiments upon this important subject to a period, when the heat of political feeling being somewhat allayed, they might be enabled to examine with maturer deliberation, with more scrutinising caution, and with more rigid impartiality, the truth of the information upon which, judging from the reports of its secret committees, the house must be presumed to have acted; that the petitioners could not avoid feeling that the character, not only of the towns in which, they reside, but of the very populous district that surrounds them, and perhaps even of the county of Lancaster at large, was inrolved in the charges of disaffection, disloyalty, and treason, which wore so larishly heaped on the most numerous and the most industrious class of its population; that the petitioners take leave to assert to the house, not only that the conduct of the labouring part of their fellowtownsmen at that period did not exhibit the slightest tendeney to insubordination or violence, but that they sustained an unparalleled extremity of distress with fortitude the most exemplary and heroic ; that without stating themselves to concur in the propriety, or to defend the prudence of all the political conduct of the working elasses in their ncighbourhood, the petitioners hare no lesitation in assuring the house, as the result of their eareful and assiduous inquiries, that 
the proceedings of that part of the population hare been completely and most grossly misrepresented; that as far as regards the meeting of the 10th of March, familiarly known by the designation of the "blanket meeting," nothing could exceed the quietness and order with which the populace procecterl to it, and demeaned themselves throughout its continuance; that it had been publicly announced sereral days, and not the slightert intimation of its imputed illegality was given; that no attempt was made to dieperse it by means of the ciril power, but that, without warning, and, as the petitioners verily believe, without even realing the riot act, doubtful as it is, whether, under such cireumstances, that stntute could legally be enforced, the dragoons, neting under the orders of the magistrates, dashed impetuously amongst the multitude, and compelled it to seek safety in flight, although magistrates at that period did not possess the dis. cretionary power over jullic meetings with which the house has since invested them; and between two and three hundred persons, who were proeceding on the rond to London with petitions, were, in the course of the before-mentioned clay, apprehended and lodged, under circumstances of great laurlship, in n prison which contained, before their arrival, nearly three lines the number of prisoners it was originally calculated to receive; and that eight of the persons then arrested, who refused to give bail for their future appearance, were committed to Lancuster Castle, and after being detained in gaol amongst prisoners of the most profligate und abandoned description for nearly six months, were ut length discharget without trial; that on Saturlay, the 29th of Mnrch, public apprehension was most generally and painfully exeited, by the appearance of an adrertisement issued by the maristracy and police of Manchester, bearing .date the preceding day, and in which they stated, that 'information, on which they could place the fullent reliance, had reached them, of " nost daring and tunitorous conspirney, the objeet of which was nothing less than open rebellion and insurrection;' that 'the town of Manchester was one of the first pointed out for attack, and the uoment tixed upon for the dintolical enterprise wus the night of the 3oth of SIrreh; that as the petitioners could not think it possible that the magistrutes or police would wantonly or thoughtlessly trifle with publie: slartn, by miking so horrible a charge on dubious or insulicient grounds, they contidently expecterl to see such daring and desperate offenders ns those inpliented in this 'diabolical enterprise' must necessarily be so supposecl to be, brought to early trial and condign punishment, particularly as on the 23rd of April, when the (xamination of the supposed delinguents must, as the petitioners con- 
ceive, have brought the eridence against them under his magisterial cognizance, the Rev. W. R. Hay, stipendiary ehairinan of the Salford quarter sessions, did, in his address to the grand jury, allude to the subject in the following terms:- 'As judieial inquiries would bo instigated against the offending parties, it would not be just to enter much upon the subject; but he might be permitted to say, should such inquiries take place, purposes of the blackest enormity must be disclosed to the publie, and that those who professed to doubt their existence, would finally be constrained to admit the existence of the whole of them;' that the suspension of the act of habeas corpus being, as appears by the term of the bill itself, applicable only to persons ' suspeeted of entertaining designs hostilo to his majesty's government,' the petitioners eonceire that it never was intended by the house to supersede the necessity of publie judicial inquiries into charges of treason, distinct and speeified in their character, and of unparalleled atrocity in their complexion; that the petitioners are therefore persuaded that the house will learn with astonishment, that all the persons arrested as participators in this alleged conspiracy have been-diseharged without trial; and they would further represent to the house, that if the slightest suspicion of the guilt of the parties still remains, it is most dangerous to the welfare and tranquillity of the country at large, to restore to liberty, and consequently to the eapability of doing misehief, men who have connected themselves with a design of such dreadful wickedness! whilst, on the other hand, if there is no foundation for the diabolical conspiracy imputed to them, every principle of justice and humanity imperiously demand that they should be publicly and legally delivered from the eharges to which they have been so foully aud fulsely subjected; that the attention of the petitioners having been aroused by the charge of these alleged conspirators without trinl, some of them have entered upon an extensive and rigid investigation of the grounds upon which traitorous and rebellious proceedings were imputed to the partie taken into custody, and the result of the inrestigation is a most positive and irrefragable conrietion that no sueh eonspiraey existed, that no violent designs were in eontemplation, and that no measure dangerous to publie tranquillity was erer proposed or dis. cussed at any of the meetings which took place, exeept by hired spies and inforners; that whilst the petitioners are convinced that no effort was left untried by these wicked and detestable emissuries, to ensnare and delude the labouring elasses into acts of riot and insubordination, they cannot but think it will be satisfuetory to the house to reflect that the illegal schemes and exhortations of these miscreants, though 
addressed to men suffering the most distressing privations, have been so eminently and unifornnly unsucessful; that the conviction of the petitioners, as to the activity of the spies, in endeavouring to engage persons knows to the petitioners for parliamentary reform, in their own villainous machinations, does not rest on general and indefinable impressions; but the petitioners believe that their habitual violence, their endearours to seduce individuals to the commission of specific crimes, which would deservedly subject them to capital punishments, their officiousness in appointing meetings in different parts of the country, their activity in procuring a large attendance at such meetings, their assumed names, their apprehension and immediate discharge, and their comection with the magistracy or police, can be clearly and iudisputably demonstrated ; the petitioners would further state to the house, that, during the early part of the last year nocturnal domiciliary visits by subordinate agents of the police, without the exhibition of warrant or authority for such proceedings, luring which the grentest abuse and inhumanity was displayed, were of disgracefully frequent oceurrence; the petitioners, therefore, con- ceiving that the house could neither foresee nor intend to sanction such proceedings as they. hare enumerated, and that the employment of spies in the manner and to the extent to which it has prerailed in the neighbourhoor of the petitiouers is pregnant with the most clangerous consequences to his majesty's peaceable and well-disposed subjects, and anxious also to vindicnte to the country at large the loyalty and good eharacter of that extensire and populous distriet, do liumbly, but most earnestly intrent that the house will be pleased to institute a strict inquiry into the trutl of the matters stated in this petition, and also into the general procedings, not only of the labouring classes, but of the magistracy and police of Manchester and its neighbourhood, during the early part of the past year; and the petitioners do hereby pledge themselves to use the utmost diligence and uluerity in furnishing the house with such evidence as they confidently believe will most fully and completely establish tho conclusions they themselves have formed on the subject."

Mr. Gcorge Philips, on presenting this petition, entered at considerable length upon the events of 1817 , of which a sketch has already been given, and concluded by stating his intention, at some carly day, to refer it to a committee. In the meantime the names of the twenty-seven persons who had signed the petition, and had offered to ineur the expense 
and trouble of obtaining evidence to lay before the House of Commons, were procured by partics opposed to any inquiry, and printed on a broad sheet, which was pasted up in counting houses; as a pretty plain intimation that the men who were daring enough to assert that gorernment had any hand in exciting the discontented to overt acts of sedition, could not expect to have any commercial transactions with the loyal friends of social order.

A number of other petitions were sent by individuals who had suffered under the suspension of the law. Old John Knight represented that, on the night of the 30th of March, 1817, he had been apprehended in bed by Nadin, handcuffed, and conveyed to the New Bailey prison, and kept there till the 6th of April, and then sent, heavily ironed, to London, and committed to Tothill-fields prison on suspicion of high treason;-that on the 10th of April he was removed to Reading jail, where he remained till the 9 th of July, whence he was taken to Salisbury jail, where he was put into a small, gloomy, stinking felons' cell, and surrounded by noisy, brutal prisoners of that description;-that he was then removed to Worcester jail, where he was confined to the end of the year, and then, being told he would be discharged, he proeeeded to London, where he had to wait till the 31st of January, when the attorney general moved the discharge of all the recognizances of the state prisoners;and that he then returned home "impaired in health by long and elose imprisonment, and his family and pecuniary affairs incalculably injured." Joseph Mitehell, in like manner, complained of an incareeration for 240 days, on a charge of high treason, never attempted to be substantiated. William Ogden stated that he, an old man of 74, had been appreliended by Nadin on the 9th of March, 1817, and sent off to Horsemonger-lane prison, where the ponderous irons with which he was loaded " broke his belly," and dangerous hernia ensued; and he prayed the house not to pass an act of indennity which should prevent his seeking redress for 
his imprisonment and the eruelty which he had experienced. William Benbow, of Manchester, stated that he had been apprehended in Dublin on the 16th of May, and sent to the house of correction in Coldbath-fields, where he was confined eight months and then discharged, without trial, two hundred miles from his home, without the means of eonveying himself thither. Amongst the petitioners was Elijah Dixon, now a prosperous manufacturer of lueifer matches, who was suspected of dealing in matters even more inflammatory. His statement set forth, "that the petitioner was, on the 12th of March, 1817, whilst following his lawful oecupation, apprehended by a warrant issued by Lord Sidmouth, and earried to London in double irons, and was, on the 15 th of the same month, committed to Tothillfields bridewell by the same noble lord, on suspicion of high treason, and there detained till the 13th of November, although the same noble lord must, or might, hare known that he was perfectly innocent of the crime imputed to him; the petitioner, therefore, prays that the house will please to consider the justiec of making the said noble lord responsible for the loss of time of the petitioner, and for the injuries which his family has suffered in consequence of his long, unjust, and unredressed imprisonment; he also prays that they will be pleased to adopt such a reform in the eleetion of members to serve in the house; as shall give each man a feeling sense that he is represented, and enable him once more proudly to boast of our glorious constitution in king, lords, and commons." Samuel Bamford, whose apprehension by Nadin has already been described, was also amongst the number of the petitioners. His prayer was, "that the house will no longer countenance a system of terror, of blood, and of oppression, by granting to his majesty's ministers a bill, indemnifying them from the consequenees of outrages by them committed against the constitution of this realm."

Mr. G. Philips, on the 5th of Mareh, made his motion 
for an inquiry into the conduct of spies and informers with respect to treasonable and seditious practices, and in the course of his specech said, "he would not assert that ministers had made the plot, but he would say that they had made the most of it; and no instruments could be found so convenient for their purposes as spies and informers, by whose means the dread of violence and treason was kept alive, and the attention both of parliament and the public was effectually diverted from those questions of. politieal economy and retrenchment which had been so peeuliarly harassing to the government." Mr. F. Robinson (Cobbett's "Prosperity Robinson") said he believed, on his hononr and conscience, that the petitions were false, and he begged the house, on behalf of a calumniated government, a calumniated magistracy, and in the sacred names of truth and justice, to reject the motion. Mr. Blackburne, the member for Lancashire, said that the twenty-seren names which vere said to be signed to the petition were not the names of most respectable people, as had been stated, but, on the contrary, were those of some of the lower elasses of society. Besides, what they stated could not be true, because he had received a letter signed by three magistrates, denying the truth of their allegations. After a pretty long debate the house divided. There were against the motion 162, for it 69, being a majority of 93 against inquiry. A previous motion to a sinilar effect, moved by Lord Folkstone, now Earl Radnor, had met a similar fate, there being against it 167 , for it 58 , majority against inquiry 109 . The bill of indemnity was read a first time on the 9th of March, the number roting against all redress for violations of the law by ministers; mangistrates, and constables being 190, while the rotes against the bill were only 64. Amongst the speakers was Sir Samuel Romilly, who begged the house to consider well the precedent it was about to establish. "In time of profound peace," he said, " on any appearance of discontent, or any alarn of insurrection, the Habeas Corpus 
Act might be suspended; and the suspension having once taken place, magistrates were at liberty to disregard all law,-to exercise what arbitrary acts of power they thought proper,-spies and informers werc to be busily employed to betray the rash and inconsiderate, who wcre labouring under the pressure of penury and distress, to their destruction,-and, under cover of indemnity, a total denial of justice was to prevail for those who had suffered grievous wrongs."

The reason why ouly twenty-seven names were put to the petition praying for inquiry was, that it was a document pledging all who attached their. signatures to a heary responsibility, both of expense and labour. They consisted mainly of the persons whom Richard Potter liked to designate as the "small but determined band." There were men amongst them of ancient family, of great wealth, and of no inconsiderable talents, and they all held respeetable stations in a commercial and manufacturing com: munity. 'They were men, also, of the elass in which, in better times, members of parliament for counties and large boroughs were to be found, in lien of the Blackburnes, who said they were of the "lower orders," and not "respectable." To have any sympathy, then, with the poverty-stricken multitude, except when they eame with bated breath and pauper aceents, was to forfeit all elaim to the name of gentleman.

The prosperity boasted of in the Regent's speech was of short durntion, furnishing another proof that a nation cannot continue prosperous when food is dear. Wages, as usual when the price of bread is high, were low. The operative cotton spinners forbidden to speak of polities, as treason against the government, struck against their masters for an adrance of wages. The contest grew more bitter the longer it lasted; and in an attack on Mr. Gray's mill, supposed to be for the purpose of destroying or damaging the machinery, some shots were fired by the 
soldiers or police officers placed within, by which some were wounded and one man killed. The coroner's jury brought in a verdict of justifiable homicide. Sidmouth, who had convinced his conscience that severity was mercy, rejoiced in the verdict, and in the committal to prison of some radicals, who had not profited by the lessons read to them during the suspension of the Habeas Corpus Act. Writing to Lord Ellenborough, to cheer him after his defeat by William Hone, he says:- " The combination at Manchester is now nearly dissolved. The verdict of the jury in the case of the person killed in the attack on Gray's mill, the arrest of Johnson, Baguley, and Drummond, who are lodged in Chester gaol, the failure of pecuniary supplies, and the admirable arrangements of Sir John Byng, in conjunction with the civil authorities, have effected this fortunate change." His complacent lordship had soon to find that a forced tranquillity was a transicnt one. He had not the good harvest of 1813 to aid his endeavours; and wheat at $80 \mathrm{~s}$., intended to be the minimum price by the framers of the 1815 corn law, revived the radical agitation which he believed he had put down by his wholesome, peace-giving, eontent-creating severities. 


\section{CHAPTER IX.}

MR. JOHY EDWARD TAYLOR'S TRIAL.

The trial of Mr. John Edward Taylor for libel was occasioned by that bitter party spirit which sought every seemingly safe opportunity of throwing contumely upon reformers. He was one of the "twenty-seren" who signed the petition to the House of Conmons, which gave so mueh offence to the powers that then were in Manchester, and there was a strong suspicion that he was its author. If he could not be indicted for sedition and treason, he might be reached in some other way; if he could not be disgraced, he might, at least, be lowered in public estimation by exchusion from local office. On the first of July, 1818, a meeting of the commissioners of police for Salford was held, for the purpose of appointing assessors; and a list of the names of persons intended to be proposed, amongst which was that of Mr. 'Taylor, was lying on the table. When the list was read, Mr. John Greenwood said,- "I think I heard some gentleman object to $\mathbf{M r}$. Taylor." Not finding any one respond to the invited objection, he again sail,-_"Some gentleman has objected to Mr. Taylor." No one had objected. Mr. Gill asked, "Who is this Mr. Taylor ?" Mr. Greenwood replied,"He is one of those reformers who go about the country making speeches." Mr. Joseph Brotherton observed, that Mr. Taylor would not make a worse assessor for being a politician, for if he was a reformer he was a moderate one. "Moderate, indeed!" replied Greenwood. "He was the author of a handbill that caused the Manchester Fxchange to be set on fire in 1812." Mr. Brotherton observed, that he thought it behored a person to have 
good authority before venturing upon such assertious. Mr. Greenwood said, he had good authority for it. Mr. Taylor hearing of these asscrtions in the Fxchange, in the street, and in company, sent a note to Mr. Greenwood, requesting to know on what authority they were made. There was no reply. After waiting two days a second note was sent; still there was no reply. Mr. Taylor requested me to take a third note, and personally to obtain an answer. Things began to look serious. I said, "Will you fight, Taylor, if he should refer to that kind of satisfaction ?" "Certainly I will," he said. "Have you ever fired a pistol in your life ?" I asked. "I have not," was the reply. "Then you shall not have me as your second, for you would be as likely to wing me as to shoot Mr. Greenwood." Taylor seriously begging that I would be grave, I said, "I will take your message, but understand me clearly, I never will in my lifetime have anything to do with a duel. You cannot prove that you were not the author of the plaeard by sending a bullet through him, and you will be an unmitigated ass if you give him the chance of sending one through you. If there is to be a deseent to sueh folly, I retire."

With Mr. Taylor's missive in my hand, I went to Greenwood's warehouse. When he had opened the note which I gave to him, and had read a few lines of it, he asked, "What's this about :" I was at the time making me remark to a gentleman from Kington, who was in the counting-room, and did not answer the question, as Mr. G. continued reading. When he had done he repeated the question. I said,- "I presume the eards Mr. Taylor. has sent sufficiently explain his meaning.' He said,- "I don't want to be troubled with notes from Mr. Taylor; I know nothing at all about the business." I said,-"Mr. 'Taylor wishes you to explain on what grounds you asserted that he was the author of the handbill." He replied,-_. I did not assert any such thing; I only said that he was reported to be the author." "And 
you made that a ground for his exclusion from a public office. Am I to tell Mr. Taylor that you did not assert that be was the author?" He said,-“"You may tell Mr. Taylor what you like; I don't want to have anything to say to him. Let him mind his business, and I will mind mine." I said,-“Mr. Taylor will not allow his character to be spoken of in the way it is reported you spoke of it." "Does Mr. Taylor mean to say that he was not the author of the handbill?" "Mr. Taylor will not answer that question until you have explained your reasons for considering him the author." "I am not a political man," he replied; "I don't meddle with politics, and it would be better for Mr. Taylor that he did not; but if people will go about to disturb the peace and create disaffection, I deem it my duty to take notice of them." "If, sir? Do you mean to say that Mr. Taylor has ever attempted to disturb the peace and ereate disaffection ?" I will not be pumped," he replied. "Your name is Prentice, is it?" "It is." "Well, then, Mr. Prentice, it would be better for you and Mr. Taylor to mind your business, and let polities alone." I said,-_"Mr. Greenwood, that is our consideration. Mr. Taylor must take care that his character is let alone, and he wants from you a direct answer to his notes." "I dou't want anything to do with ,Mr. Taylor or his notes." "Is that your answer, sir ?" I asked. He replied,_- "You may say what you like." "Very welh sir. Good morning." And so I left him, with a pretty strong convietion that he was not exactly the person that would run rashly into a duel, even with a man who had never in his life fired off a pistol.

Taylor was, naturally, much irritated, and, smarting at the repetition of vulgar insult, he sent the following note to his traducer :-

"Sir,-Your not haring given my frienc, Mr. Prentice, any explanation as to the subject referred to in my former note, compels me to consider you as the fabricator of the report in question. 
"I therefore now tell you, that as you have had the baseness to traduce my character, without having the manliness to justify your own conduct, - as you hare made assertions respecting me equally false as they are malicious, and met the attempts of my friend to procure from you a candid avowal or disarowal of your conduct, by new insinuations still more unjustifiable than the former, you have proved yourself a liar, a slanderer, and a scoundrel.

"I shall not fail to make my opinion of you at least as public as ire your calumnies against me; and I shall take the earliest opportunity that presents itself of telling you to your face what I think of you.

I am, \&c.,

"JoHs Edward TAYLOR.

"Toll-lane Buildings, Thursday afternoon, July 16th, 1818."

Mr. Greenwood having, four or five days after receiving this note, repeated to Mr. Brotherton that he had good authority for charging Mr. Taylor with having written the placard, that gentleman published a letter in Cowdroy's Gazette, referring to the correspondence, and stating that a copy of it should lie at the printer's for public inspection.

The grand jury, at the Salford quarter sessions, on the 27th of October, found an indictment against John Edward Taylor, late of Salford, ehapman, for that he, being a person of an evil and malignant disposition, and intending and devising, as mueh as in him lay, to injure and vilify the good name, fame, credit, and reputation of John Grecnwood, with force and arms, of great hatred, malice, and ill will towards the said John Greenwood, wickedly, maliciously, and unlawfully did write, and cause and procure to be written, certain false, scandalous, and defamatory words, \&c.

Knowing, as Mr. Taylor did, the nature of the eourt of quarter sessions of Salford, his solicitor, Mr. Atkinson, applied for and obtained a writ of certiocari to remove the indictment into the Court of King's Bench. The trial took place at the Lancaster spring assizes, on the 29th of Mareh, 1819. Mr. Taylor, who had resolved to undertake his defence in person, was accompanied by Mr. Edward Baxter, 
Mr. Joseph Brotherton, Mr. F. R. Atkinson, Mr. Johu Shuttleworth, Mr. Rickards, my friend Mr. John Childs, of Bungay, and myself, that he might see friendly faces round him while he was in a position of some danger. Scarlett, afterwards Lord Abinger, who was employed for the prosecution, made a very short speech, assuming the utmost nonchalance, as if the jury could not for a single moment doubt the propriety of finding a verdiet of guilty where the libel was so flagrant. "It would be a mere waste of time," he said, " to enter into a letail of circumstances which camnot be the subject of your consideration, or at all influence you in the verdict you are to pronounce;" the defendant would have an opportunity in the Court of King's Bench, when ealled up for judgment, to urge any extenuatory circumstances; all that the jury had to do was to inquire whether he had written the letter, and if its contents were libellous. And then he dropped down his portly person into his seat with an air that plainly said, "There's an end on't. You have no choice but to say "guilty.", The only evidence offered was the proof of publication.

Mr. Taylor took a legal objection, eiting a case from the law reports. The old east-iron-faced juclge listened impatiently. "Have you done now :" he asked, in his gruffest voice.

Mr. Taylor.-Yes, my lord.

Baron Wood.-Then there's nothing in it!

Never was poor defendant eut so short before. "Have you done now :" " les, my lord." " Then there's nothing in it." It was as pretty a sequence of three sentences as ever was uttered; and for months afterwards we never recollected it without loud langhter. 'The defendant turned from the judge to she jury, and told them that they were the sole judges of the law as well as of the fact. He said:-

"I protest, gentlemen, against truth being visited with the ponalties of falsehood. I protest against the cloctrine of the courts, that the truth of a libel constitutes an aggrarntion of the charge; and prepared 
as I am on this occasion to justify every word I have written, and to prove erery accusation I have made, I would give no man the power of undernining the basis of my defence, by a tame, spiritless acquiescence in those odious dicta of servile lawyers, which reason, and justice, and truth equally deprecate and diselaim. What, indeed, can be more monstrous than the position, that the utterance of truth is an offence rightly punishable by the criminal law ? What can be more inconsistent, than that you, who would shrink from the bascness of personal intereourse with a liar, should yet be called upon to render amenable to fine, or imprisonment, or both, hin who has conscientiously confined himself to truth ?"

He proceeded to impress upon the jury that there was no proof of the falsehood and maliee eharged against him in the indictment. He told them that they must be satisfied, by evidence, that he was the false, wicked, and malieious person described, before they eould find him guilty ; he said that he was the person defamed, and not Mr. Greenwood; he detailed the whole of the cireumstances as I have related them; he offered to produce witnesses to prove the truth of all that he had asserted; and he concluded his speech by saying :-

"Gentlemen; upon the broad principle both of the truth of my statements as respects Greenwood, and of the intolerable provocation I have received, I feel myself entitled to your rerdict. I have not, for I could not, address you in eloquent or oratorical declamation, but I have told you 'a plain, unrarnished tale ;' I have set before you the facts as they really occurred, with those observations upon them which the circumstances of the case seemed to me to require. An apprehension of consequences, personal to myself, should nerer induce me to supplicate for your verdict; but let me again remind you, that you, and you alone, are the judges of the law as well as of the facts; and let me entreat, that with the full view of all the facts before you, you will upon this occasion prove yourselves defenders and guardians of the truth. Place yourselves in ins situation-remember the prorocation I hare received-eonsider what would hare been your own conduct, and then, following the great prineiple of Christian morality, 'so do to me as ye would that, in similar circumstances, I should do unto you ?"

Mr. Scarlett was noted for his quick perception of a jury's 
feelings. He had no doubt seen that at least one of the jurors, the foreman, Mr. J. Rylands, of Warrington, had listened with deep attention to Mr. Taylor's indignant protest against truth being punished with the penalties of falsehood, and to his confident assurance that, if the court would allow him, he would, then and there, prove that he was the person who had been defamed and vilified. He no doubt saw that there was one determined man who would impress upon his fellow-jurors the injustice of finding guilty on charges not only not proren, but in the face of an offer to prove the whole of the injustice and provoeation offered to the defendant. It was not safe to let the case go thus to the jury. There might not be witnesses present to prove the truth of Mr. Taylor's narrative; if there were, they might break down in some points of their evidence : at all events, the examination of witnesses would give him the opportunity of a REPLI, - of having the last word, - of trying his certainly strong powers in influeneing a jury; and thus to remove the impression which Mr. Taylor's speech had made. He hastily resolved to give the defendant "rope enough."

Mr. Taylor.-I offer nyy witnesses to the court, if your lordship thinks proper to hear them.

Mr. Scarlett.-I shall not object to your proving what you have stated to the jury ; for I hold it extremely wrong, Mr. Taylor, that you should state anything you are not prepared to prove.

Mr. Taylor.-If his lordship consents, I shall examine ny witnesses.

Mr. Scarlett.-My lord, I shall make no objeetions to the witnesses on the part of the defendant being examined. I will give him rope enough.

Mr. Taylor.-Very well. Call Joseph Brotherton.

Mr. Brotherton was called, and in his placid way stated what Mr. Greenwood had said of Mr. Taylor. His quietly. given eridence sceming to tell on the jury, Cross, also 
employed for the prosecution, seeing the mistake committed by Scarlett, objected to the line of examination; but the latter was reminded of his promise to give "rope enough."

In cross-examination Scarlctt asked : "Well, now, is the office of assessor one of any emolument?"-Ansuer : "No." "Or of honour?"-Answer: "No; but a person would think himself degraded in being considered unworthy to fill it." - Scarlett: "You know that is not evidence, Mr. Brotherton, but you think it may have some influence with the jury."

Mr. C. Rickards was then called, who stated that, in consequence of what had been said at the meeting of police commissioners, Mr. Taylor's name was left out of the list of assessors. I was the next witness, and detailed the conversation that had taken place between Greenwood and myself. This closed the defendant's case.

Searlett then rose, determined to punish the man who had compelled him to an imprudent concession. Taylor had made the apology for undertaking his own defence that he had determined on a course which he could not expect any gentleman at the bar to take. This Mr. Scarlett represented to be a gross libel on the bar as composed of a set of servile, spiritless, base, and grovelling wretches who had not the courage to do their duty. He went carcfully through the whole defence, to show that Mr. Taylor had been unnecessarily and unreasonably exacting. In reference to the language used in the last note he said he "had seldom found that the pursuit of reform mended a man's manners ;" he said that Mr. Taylor was a man who was in the habit of making speeches; "I have no doubt he has made more speeches in the county of Lancaster than $I$ have done ;" and aceused me of stiffness and hauteur in making a dry and abrupt demand for Mr. Greenwood's authority. He concluded a most bitter and a most. unfair attack on the defendant by saying :- " He has culled from every author 
he has read, all the fine and all the bitter things they have said, and applied them to the prosecutor; and the whole course of his defence has been the most virulent attack upon his character-and should the defendant be convicted by your verdict, of which I ean entertain no doubt, he has rendered himself a just subject for condign punishment. That the defendant wrote the letter is admitted-that it is grossly libellous is equally clear-and that it is false you must now be entirely convinced. If this should be your conviction you must necessarily pronounce the defendant guilty. But if you should doubt either that he published the letter, or its libellous nature, or if you should be of opinion that he has proved Mr. Greenwood to be a liar, a scoundrel, or a slanderer, then, in God's name acquit him."

The learned, cast-iron-faced judge then charged the jury. He confessed he might have been wrong in admitting evidence of truth, but as the counsel had consented he had not opposed; the words were libellous beyond all doubt, and " in an indictment for libel the party could not, in law, be allowed to plead in his justification the truth of what he had alleged;" if such were not the law every individual might have his foibles, his follies, or even his crimes, published in every newspaper in the kingdom for the purpose of bringing him into disgrace; there could be no doubt as to the libel, and no duubt as to the malicious intent; if the defendant was found guilty ho would have an opportunity to urge, in another place, a mitigation of punishment.

Mr. Taylor.-My lord, I request that the letters and papers which have been given in evidence may be handed to the jury.

Buron Wood (angrily).-No I won't; I shall alloys of no such thing.

$\Lambda$ few hurried words passed in the jury-box. It was seen that there was not to be an agrecment in court. The foreman, honest, firm, conscientious John Rylands, took 
his great coat from the front of the bar where he had hung it, and threw it over his arm with an energy and determination of air which led Mr. Childs to remark to Taylor :"That man will aequit you." In a letter to me Childs says:- "I have often desired since to see again that sedate, earnest, strong, thoughtful-looking man, but after the events of that day I have never had the opportunity, yet I hare never forgotten him." The jury retired.

Mr. Taylor, his sister, and his friends sat in court listening to the next case, turning their heads at every distant sound to see if the jury were coming back, but the day wore heavily on without any sign, and at length the court broke up. Several of us afterwards went to the foot of the stair, which led to the room where the jury were eonfined. There sat at the door, a man who was eharged to keep it sacred from the approach of any persons whatever. $\mathrm{He}$ said he had heard loud words for several hours, at intervals, but for a long while past they had been very quiet. We returned to our iun, under the eonviction that the longer the jury remained out, the better the case stood, and from time to time kept returning to watch, and to learn if any sound had been heard from the mysterious room,-but no-the men might be dead, for aught we eould learn or hear.

Thus we paeed the streets of Laneaster, hour after hour. It was a wild, howling night, with eontinued blasts and hail storms. Sometines we stood and watehed the window of the tower which contained the jury, and contemplated their condition on such a wintry day and night as that had been, eonfined and kept so many hours without food, or drink, or tobacco, "or coal, or candle-light." Thus at intervals of half an hour, an hour, and so on, more or less, we sauntered backwards and forwards, hearing the Lancaster cloeks strike hour after hour. $\mathbf{A}$ few of our number determined to go, yet once again, to have a few words with the keeper of the door, with whom by this time, from their 
numerous visits to him, they scemed to have become familiar acquaintanee. They went this time, rather with a view to bid the man good night, or have a few more last words, than with any expectation that there would be any move or stir before morning, when, suddenly, while they were talking with the door-keeper, there was a most unearthly yell: "Open the door!"-then a confused bustle,-then their familiar with whom they had been speaking, became authoritative. " $O$, get away gentlemen, the jury are agreed," said he; and sure enough it was the jury"agreed." By the dim light which was refleeted upon them when the door opened, and as they descended from their dark chamber, they formed the oddest spectacle, and made the queerest picture imaginable. It was obvious that all the arts they could devise to keep themselves warm had been tried; two had handkerchiefs tied on their heads, and all made a most piteous appearance. The bailiff who had charge of them now arranged them two abreast, and marched them off towards the judges' lodging, whither at the elose of the court, it had been decided they should proceed to deliver their verdict, whenever they came to an agreement. The judges were then lodged at a considerable distance from the courts, and our friends and Taylor kept close to the jury, who were escorted, through the up and down, narrow, dark streets of Lancaster, with onc poor lantern before them. The days of gas-there-were not yet. Two of the jury-elderly men-conversed together as they staggered along. One was overheard saying :"This is a dreadful business, sir,-I shall never get over it ; I am quite perished." "I hope," said he, next him, " they won't keep us long at the judges' house, and then we must get back as quick as we can, and get some hot brandy, sir." Our friends reached the door, and there was a little jostling, but instantly came an officer from the inside, who begged that all might be condueted as quietly as possible, and requested the jury to follow him. Taylor 
and his friends stuck to the jury, went up, one flight of broad stairs, then another, where there was a stand still, on a large open landing, the size of the vestibule below. Here the door was gently opened, and into a moderate sized bed-room, up two stairs, went the jury, attended by their companions, who represented the public and shire, where, with undrawn eurtains, bolt upright, in his night cap and bed clothing, sat Baron Wood. Think of the spectacle!

"Silence, gentlemen," said the officer.

"Gentlemen of the jury, answer to your names." They answered.

"Gentlemen of the jury, are you agreed in your verdict ?"

"We are," said the foreman, firmly, in a tone which indicated that he had achieved a vietory.

"How say you gentlemen, is John Edward Taylor guilty or not guilty ?"

In the dimness of the light of that room-for there was but a small ehamber lamp-and the oddness of the seene passing before the eyes, it would be difficult for any person to convey to another the sensation of that moment which intervened between the question and answer. " It reminded me on the instant," said one of our friends, "of that period of deepest anxiety which all must personally feel at some time or other-' that drop of time'-which is sufficient to embrace in it ' a life of pain, an age of crime.' " But when John Rylands, of Warrington, pronounced with a triumphant emphasis, "He is not guilty," there arose a burst of exultation, notwithstanding the privacy of the place, which made the whole house ring. I am not aware that the judge uttered a sentence, but the officer begged imploringly for silence, and all parties, both spectators and jury, got as quick as possible into the street, when the echoes of the old town told, tolerably loud and frequent, the fact that the verdiet was-" He is not guilty."

" The jurors were prineipally of the old school of loyalists, and had been disposed to return an immedinte rerdict of 
" guilty," but John Rylands calmly urged his objections, which were listened to very impatiently. "Well, gentlemen," said the sturdy foreman, after long discussion, "if you will insist upon that verdict, I will go to sleep and consider about it in the moning; there is my bed," throwing lis coat into one corner of the room, and then lying down upon it. His example was followed by others, apparently as stern in maintaining their own purpose. But some did not take it so comfortably; they had, for years past, been accustomed to their pipes and as many glasses of strong ale by the inn fireside as they liked, and to be thus unexpectedly deprived of those enjoyments, and to find themselves supperless in an empty room without fire or candle or bed to lie upon, was beyond endurance. One of them was really ill, and bemoaned the hardships of his case in pitcous accents: "Are you going to keep me here all night when I anı so ill ?" " Here are you," said the foreman, "whining about the hardship of being shut up for one night, and yet you would put it in the power of the court to confine a man eighteen months for having spoken the truth." The appeal was successful. There were now two for a verdict of " not guilty." The others" remaining obstinate, John Rylands stretched himself in his corner and lay in sober thoughtfulness, munching his crust quictly to eonceal his possession of it from those with whom he was locked up, until each of them, one after another, yielded to their cravings for personal comfort as of much greater importanee than the vindication of their loyalty, and then they emerged from their total darkness into dim light.

Some of the gentlemen who accompanied Taylor had gone home at the elose of the day. Taylor, Atkinson, and Childs agreed to remain till after the opening of the court in the morning, for the purpose of showing the acquitted to the judge and the bar. Ir had not been long in the court when "Lauyer Scarlett," as Cobbett used to call him, took 
the opportunity to pass by him and to say, "You had a friend on the jury yesterday, Mr. Taylor ;" to which Taylor replied, readily and well, "No, Mr. Scarlett, the jury felt that you treated me unfairly." In his conduct on that trial Scarlett showed more of the heartless man than of the reformer which he pretended to be at that time,-more of the baseness which became fully developed in his character when, after the passing of the reform bill, and fourteen years had passed, he introduced into Norwich a flood of iniquity and corruption which proved him to belong to the class who, in all ages, have regarded the end to be accomplished as justifying the means, however base the means required for its accomplishment may be.

Taylor, Atkinson, and Childs, left Lancaster at about twelve o'clock, and on their way to Manchester Mr. Childs said to Taylor, "It is now plain you have the elements of public work in you; why don't you set up a newspaper ?" and thereupon gave him what of practical detail he could relative to such a speculation.

The ability displayed by Mr. Taylor on his trial, the boldness with which he denounced the fictions of law in cases of libel, and, more than all, his success when pitted against the most successful barrister on the circuit, seem to have determined him to leave mereantile pursuits, for which he had not many qualifications. He spoke of eating his terms at one of the inns of court; but at the age of twenty. seren, without previous legal study, he felt that he had been rather too late to adopt a profession which would require five years of probation. In two years more his reform friends established him in the Manchester Guardian, and he drew, from a concurrence of most fortunate circumstances, one of the most splendid prizes, regarded in a pecuniary point of view, ever drawn in the lottery of newspaper spcculation-gaining by boldness while the enthusiasm of youth remained, and retaining by cautiousness when more mature years taught prudence and circumspection. 


\section{CHAPTER X.}

HENRY HUNT.-THE RADICAL AGITATION IN 1819.

WhEN the hand of eocreion was remored, it was likely that the spirit of discontent should find public expression. The distress throughout 1817 and 1818 had been very great, and it became more intense in this vicinity when preparatious began to be. made for the resumption of cash payments by the bank. The searcity and dearness of money greatly lessened the value of all manufactured produets, and the working classes, as usual, were the first to feel the effects of the decp commercial depression. They were taught to look upon misgorernment as the cause of their miscry, and they attributed that misgovernment to the grossly defective state of the representation. They saw Manchester, Salford, Bolton, Blackburn, Rochdale, Bury, Ashton-under-Lyne, Oldham, and Stockport without members, whilst Old Sarum-a mound of earth without inhabitants-and a host of villages, decayed and rotten, each sent two. It was not to be wondered at that they complained, -not to be wondered at that they erowded round those who appealed to their sympathies, gave articulate utterance to their complaints, and offered to aid them in obtaining redress of their grierances.

A fresh campaign was vigorously commenced with the commencement of the year 1819. Henry Hunt had come forwarl as a champion of the people's rights, and he was well fitted to appeal with effeet to the exeited passions of the multitude. IIis portrait is thus drawn by Samuel Bamford, on the oceasion of the radical laureate's first visit to London, in an earlier stage of the agitation: "He was gentlenanly in his manner and attire; six feet and better 
in height, and extremely well formed. He was dressed in a blue lapelled coat, light waistcoat and kerseys, and topped boots; his leg and foot were about the firmest and neatest I ever saw. He wore his own hair; it was in moderate quantity, and a little grey. His features were regular, and there was a kind of youthful blandness about them which, in amicable discussion, gave his face a most agreeable expression. His lips were delieately thin, and receding; but there was a dumb utterance about them which, in all the portraits I have seen of him, was never truly eopied. His eyes were blue, or light grey-not very clear, nor quick, but rather heary, except-as I afterwards had opportunities for observing-when he was exeited in speaking, at which times they seemed to distend and protrude; and if he worked himself furious, as he sometimes would, they became blood-streaked, and almost started from their sockets."

On the 25th of January Hunt made a public entry into Manchester from Stockport, aecompanied by the indomitable John Knight; Ogden, charaeterized by Canning as the " revered and ruptured ;" Mark Wardle, the printer of the Manchester Observer, a paper which was established as the organ of radicalism; and a number of others. The procession boasted of many gay flags, a kind of display which Hunt exceedingly liked. The meeting was very numerous and very peaeeable, and there was applause enough to satisfy eren Hunt; but his appetite grew with what it fed upon, and he must needs appear at the theatre, to hare his share of the plaudits usually dealt out there. He went on the following Friday night, accompanied by a number of friends, some of whom, earnest reformers, went rehctantly, thinking that men who were working for national regeneration should not waste their time in idle amusements. He was received with "great applause" by a portion of the audience, and that exeited the ire of another portion. "God save the King" was ealled for, to show him the loyalty of Manehester, 
and, on the pretence that he did not show the usual marks of respeet for the national anthem, he was rudely assailed by some military officers and some hot-headed residents, and at length forcibly expelled from the house. Smarting under this infliction, which was more disgraceful to his assailants than to himself, he sent for Bamford, and told him that he meant to go to the theatre another night, and that his attendance and that of ten or a dozen "stout fellows," in the pit and at the Fountain-street entrance, would be acceptable. A party of ten was accordingly formed and marehed into Manehester. "It consisted of myself," says Banford, "and nine picked men of my acquaintance from Middleton. Our business was to attend the play, to protect Mr. Iunt, if requisite, and to retaliate with punishment any insult that might be offered to him or any of his friends." They were all armed with sticks; " some carried blackthorn, some hazel, and others again had taken a fancy to that portable and effective cudgel, the green English holly:" Here was Hunt going to court insult, and poor, simple Bamford and his nine picked men, and Irishmen with shillelalss under their long coats, to protect or retaliate! The street was filled, but the door was not opened, and the erowd began to be impatient. At length a messenger arrived from MIr. Ward, the manager, to announce that there would be no play. Bamford demanded to see Ward, and was admitted. An old aequaintance advaneed to meet him :-

" 'Bamford! wot the d- art thou doing here?' 'Hallo, friend Nadin; is that you :' was ury reply. It was Mr. Naclin, the deputy constuble, who spoke. 'Me?-aye, it's me; but wot the d-1 dus theaw want ith' teawn at this time o'th' neet?' I'n come to th' play, th' same as yo' nr', I suppose. But I want neaw to see Mr. Ward, th' manager.' Several persons spoke, and I think they said he was in conversation with the head constable. "Wot mun theaw want to see a play for '? sail Mr. Nadin.' 'Oh! I'm rather curious to see one; I melerstand it's to be a good un to-neet.' 'I kno' thee of owd' I've seen thee afore at Middleton.' Theaw may 
go wom ; theaw'll see no play here.' 'I'll see one iv there is ony to be seen, or I'll ston at yon dur till twelve o'clock : that yo' may depend on, Jozy.' 'Who ar' yon gang 'at theaw has wi' the'?' he said. 'Oh! they 're a set o' lads fro' different heawses obewat; they'n tell yo' if yo'n ax' 'm.' 'Well, they'd better pack off, an' thee wi' 'em, for by —, if there's any damage done, I'll look afther yo'. Theaw may tell 'em, they'n ha' no play to-neet.' 'Then nobody will,' said I, as I went out, and shut the door after me. I had scarcely got to my former station, when a coach drove into the street, and on its being ascertained that it contained Hunt, Thomas Chapman, and other friends, a loud huzza burst from the dense multitude, mingled with a few hisses ; but the minority were quiekly silenced. Hunt then mounted the box, and addressing the people, stated that the manager had written to him, saying there would not be any performance that night, and requesting ( $I$ think) that he would come up and try to get the people to disperse, and go home. He next entered on some general topics, and with singular bad taste, to say the least of it (for his impetuosity orer-ran his judgment), he said, "the authorities only wanted a pretext to let the bloody butchers of Waterloo loose upon the people;' and coneluded by adrising them to retire to their homes peaceably. We then gare three cheers; the carriage disappeared, and the street was soon deserted. Our party went to the Robin Hood, where we were joined by a score or two others, and we set to, and caroused until midnight, and then returned home."

Hunt's folly in going to eourt insult was more than matched by the impudenee and insolenee of some of the "respectable" inhabitants. A party of coarse ruffians, in the garb of gentlemen, foreed themselves into his private room in the Spread Eagle, and signalized their bravery by offering battle to a few friends who had met to spend a quiet evening with him. "They were a set of lueky dogs," says Bamford. "Had they been taken by us in the faet, there would have been a sore and pitiable account of them in the morning." They were not, however, taken in the fact. Bamford and his pieked men were off to the Robin Hood, where they were joined by a seore or two of others, and these world-regenerators "set to and earoused till midnight, and then returned home." There was a levity 
and flippancy about all this that gives us, as we look back upon it now, little proof that the actors had any deep feeling of the responsibility they were incurring as the adrocates of great national rights; but they also furnish an argument that these men, thus idly oceupying themselves, were very far from being dangerous revolutiouists.

At the spring assizes, at Chester, Baguley and some others were tried, found guilty, and sentenced to two years' imprisonment, for seditious harangues at Stoekport. The evidence against some of them was strong enough, if the witnesses were to be believed; but if anything was deficient in proof as to the harangues of each individual prisoner, the law of conspiracy, as defined by judges, supplied any short-coming. They had "breathed together," and therefore each was made responsible for all that had been uttered. There was another "conspiracy" at a subsequent meeting in Stockport, in which Sir C. Wolseley, an honest, but not a very wise man; Fitton, both honest and shrewd; indomitable old Joln Knight, the " revered and ruptured" Ogden, and Harrison, took part. Sir Charles and Harrison were afterwards tried for sedition, found guilty of having breathed together, and imprisoned.

On the 21st of June, 1819, another meeting was held on St. Peter's Field, Manchester, and resolutions were passed d appointing district delegates for a general national union to reform the government. Mectings took place about the same time at Oldliam, Bolton, Royton, Bury, Heywood, Stockport, Ashton-under-Lyue, Failsworth, Gee Cross, Ices, Middleton, Rochdale, Todmorden, Barnsley, Holmfirth, Leeds, and other towns, all unrepresented in parliament; and, says Mr. Wheeler, "with a view to embarrass the government, a pledge was generally entered into by the people attending the several places of rendezrous to abstain from the use of any cxciseable article not absolutely neecssary to support existence." Hunt, to supply the place of coffee, recommended his own roasted 
corn, which was found to be a very unpalatable substitute; and sloe leaves did not produce so pleasant a beverage as tea. The main stress was laid on abstinence from spirits and ale; and the good old loyalists were shocked at the iniquity of soberness from such a motive. A placard, signed, "Bob Short," was stuck on all the walls, and distributed from house to house, denouneing all as enemies to the working people who would persuade them to renounce the use of the good old English drinks, and urging the readers to return to their good old drunken habits, to prove their attachment to king, and ehurch, and constitution, endangered by this conspiracy to promote sobriety. The expense of this precious production, amounting to some eighty pounds, was defrayed from the church-rates! The item for "printing" was objected to at the parish table, on the ground that the particulars were not given, but it was passed notwithstanding. An application to the Court of King's Bench was made, and a mandamus was issued that the particulars should be laid before the parish, in vestry assembled, on which the churchwardens, ashamed, not of issuing, but in being found out in issuing, persuasires to drunkenness, withdrew the item entirely from their aceounts, which were then passed. This attempt to pay out of churchrates, for an earnest ineulcation of the duty of drunkenness, created a desire to inquire more strictly into the ehurchwarden's expenditure; and it was found, at a subsequent vestry meeting, that three bottles of wine, per man, besides brandy, had been consumed at their annual dinner, and I remarked, on the use of brandy in addition to this intolerable quantity of saek, that probably the three ehurchwardens had remained, after their company had left them, to sing :-

"Here are we met three merry boys,

Three merry boys I trow are we."

Meeting one of the churchwardens, a few days afterwards he asked-" How did you know that we sang "Willie brew'd a peek o' malt!", 
"It was desirable," says Mr. Wheeler, " to stop these combined morements of the disaffected." The combined movements were, frequently public meetings, "training," and abstinence from intoxicating liquors; as for abstinence from coffec, all Hunt's popularity could not make a decoction from his roasted corn go down. For an account of the reasons for training I must borrow again from Bamford :-

"These drillings were also to our sedentary weavers and spinners periods of healthful exercise and enjoyment. Our drill masters were generally old soldiers of the line, of the militia, or local militis regiments; they put the lads through their faeings in quiek time, and soon leamed them to mareh with a steadiness and regularity whieh would not have disgruced a regiment on parade. When dusk came, and we eonld no longer see to work, we jumped from our looms, and rushed to the sweet cool nir of the fields, or the waste lands, or the green lane sides. We mustered, we fell into rank, we faced, marched, halted, faced about, counter-marched, halted again, dressed, and wheeled, in quick succession, and without confusion; or, in the grey of a fine Sunday mon, we would saunter through the mists, fragrant with the night odour of flowers, and of new lay, and ascending the Tandle IIills, salute the broad sun as he elimbed from the high moose of Saddleworth. - * There were not any arms-no use for any-no pretence for any; nor would they hare been permitted. Some of the elderly men, the old soldiers, or those who came to watch, might bring a walking staff, or a young fellow might pull a stake from a hedge, in going to drill or in returning hoine; but, assuredly, wo lund nothing like arms about us. There were no armed meetingsthere were no midnight meetings. Why should we seek to conceal what we had no hesitation in perforning in brond day? There was not auytling of the sort. Xo arming-no concealing meetings. Such ns $i$ have deseribed were all our drillings, about which so mueh was afterwards snicl. We obtained by them all we sought, or thought of - an expertuess and orler whilst moving in bodies; and there was no hyperbole in the statement which a magistrate afterwards made on oath, that "the party with the blue and green banners came upon the field in beautiful order!" adding, I think, that 'not until then did I become alarmel !" "

These trainings, harmless as Bamford believed them to be, excited great alarm, and scouts were sent out to see to what extent they were carried, and who were engaged in 
them, in order that if any of those persons afterwards took part in any public meeting, a connection might be proved to exist between the publie demonstration and the partially concealed training. This ehain of connection was established very eleverly. An amateur spy, of the name of Murray, went, with three others, and witnessed the drilling on White Moss. The radicals took an effectual mode of fixing the circumstances in his memory. They gare him and his companions a sound drubbing. At the trial of Hunt and others at York, the drilling was proved, the drubbing was proved, and it was also proved that a part of the procession, headed by Hunt when he entered Manchester, on the 16th of August, stopped and hooted opposite Murray's shop. Ergo, in law logic, the White Moss drillers formed a part of St. Peter's Ficld meeting ; and, ergo, that last meeting was an illegal meeting because the first was!

Were there no gentlemen acquainted with the real condition and opinions of the working classes in the neighbourhood upon the list of magistrates, to discourage the employment of spies, and to repress the riolence contemplated under the pretence of alarm ? Dr. W. Cooke Taylor, in his "Life and Times of Sir Robert Peel," says :-"In 1819, Manchester was not incorporated; in the eye of the law it was a village, and, as such, subject to the jurisdiction of the county magristrates. A rule had been established by the Chancellor of the Duchy of Lancaster, that no manufacturer should receive the commission $V$ of the peace; eonsequently, the magistrates were either landowners or clergymen. The Lancashire squires viewed the manufacturing population with a jealousy which may have been unreasonable, but eertainly was not unnatural; they saw persons suddenly becoming their rivals in wealth and influence by a course of industry and economy, which hereditary prejudiees led them to despise; and they feared that these new men would displace the ancient families. The elergy were identified in feeling with the landlords, 
by habit, eduention, and social intercourse; for a very lange proportion of the manufacturers belonged to dissenting sects. With such feelings they allowed the meeting of the 16th of August to assemble, hoping, by a coup d'état, to strike terror into the reformers of Manehester, and, perhaps. disposed to show their contempt for spinners and weavers by arresting the leader in the midst of the assembly.

The government was alarmed at the frequency of the reform meetings, at the vast numbers who thus congregated, and at the language uttered. On July 1st, Lord Sidmouth issued circular letters to the lords lieutenant of the disturbed counties, recommending prompt and effectual means for the prescrvation of the public tranquillity, and that the yeomanry should hold themselves in readiness. On the following day a meeting was held at Newhall-hill, Birmingham, where Sir Charles Wolseley was nominated "legislatorial attorney and representative" for that town. On the 30th of the month a proclamation was issued by the Prinee Regent against military training, seditious mectings and writings, and the election of legislatorial nttomies. The local authorities supplied the government with the assertions of the existence of a dangerous spirit, and earnestly besought the means of putting it down. On the 1st of July, J. Sylvester, R. Wright, W. Marriott, C. W. Lithelston, and J. Norris, magistrates, wrote to Lord Silmouth from the Manchester New Bailey Court House, stating that, urged on by the harangues of a few desperate denagogues, they anticipated "a general rising;" that as the law stood, they had no pouce to prevent these meetings; nut that they were " unarmed." The magistrates assembled at the Kinutsford quarter sessions, four of them elergymen, passed resolutions declaratory of evil designs on the part of the people, and recommending all friends of king and constitution to "rally round the standard of legal anthority, and by the manifestation of their principles, destroy the 
baneful effects of blasphemy and seditious doctrines, reclaim the deluded, give confidence to the loyal, and maintain inviolate our rights, our liberties, and our laws." A meeting at the Manchester police office, held July 16th, of the "Committee to Strengthen the Civil power," John Bradshaw, Esq., in the chair, petitioned government to supply them with arms and accoutrements for one thousand men. On the 20th of July, the grand jury, addressing the Manchester magistrates, recommended the immediate establishment of ARMED Associations for the purpose of strengthening and supporting the civil power. This document was signed by

$\begin{array}{lll}\text { Thomas Peel, } & \text { John Touchet, } & \text { John Hardman, } \\ \text { James Hay, } & \text { Arthur Clegg, } & \text { W. Hutehinson, } \\ \text { William Tetlow, } & \text { J. H. Heron, } & \text { William Lomas, } \\ \text { Christr. Parker, } & \text { T. Worthington, } & \text { Thomas Helsby, } \\ \text { Thos. Entwistle, } & \text { J. S. Barton, } & \text { John Tetlow, } \\ \text { William Hatton, } & \text { William Hill, } & \text { Robert Hay. }\end{array}$

The great object was that, as there was no law to prerent peaceably held meetings, the meetings should be connected with some illegal act elsewhere. On the 5th of August, Mr. Norris, the Manchester stipendiary magistrate, writes Lord Sidmouth, stating that a meeting eonrened for the 9th would not be held. 'This, he says, would be a great disappointment to the neighbouring towns, which had provided a number of flags and caps of liberty for the occasion. He adds :- "The drilling parties increase very extensively, and unless some mode be devised of putting this system down, it promised to become a most formidable engine of rebellion." In the doubt whether the open meetings could be connected with the drillings, it was thought very desirable that there should be some declarations of alarm for personal safety if those meetings were held, and, accordingly, we have, on the 7 th of August, the informations of S. N., S. E., D. N., and D. R. all of Bury-the full names are not giren-before Ralph 
Fletcher, of Bolton, a magistrate, formerly notorious for the employment of spies. The informants say: "We all upon our oath say, that in various parts of the neighbourhood of Bury aforesaid, there are nightly assemblies of great numbers of men, who meet together to learn and practise military training, which these informants verily believe to be intended to qualify them for hostile purposes against the government of the country, and against the peace of our lord the king, his erown and dignity, and to the disturbanee of them, these informants, who hereby assert their fears for their personal sufety; and therefore they, these informants, pray that these men so training in large bodies, to the terror of his majesty's subjects, may be apprehended and committed to find sureties to keep the peace." Further informations, to the same effect, are sworn on the 9th of August, before Ralph Fleteher and James Watkins, whose names will be recollected in connection with the West Houghton afficir, in 1812. Ralph Fletcher writes, on the 10th of August, to Lord Sidmouth, representing that the public meetings are so demoralizing and so terrifying to his majesty's loyal subjects, that, "under whatever pretext they may be called," they ought to be suppressed. On the 12th of August Mr. Norris, whose legal knowledge was about co-extensive with the weakness of his judgment, again writes Lord Sidmouth, and says, in reference to the drillings: "They affeet to say that it is for the purpose of appearing at Mancliester in better order, \&c., on Monday next; but military discipline was not requisite for this pupose, and a more alarming object is so palpable that it is inpossible not to feel a moral conviction that insurrection and rebellion is their ulterior object." $\Lambda$ the sane time the Cheshire magistrates, assembled at Knutsford, send a memorial to Lord Sidmouth, asserting that thousands. of young persons in schools were taught principles of a most dangerous tendeney, and praying that such sehools should be suppressed, and that "if the existing law's are not 
sufficient for that purpose, others should be framed for their prevention." The names of the persons thus memorializing were :-

$\begin{array}{lll}\text { Earl of Stamford, } & \text { Sir J. T. Stanley, } & \text { Peter Brooke, } \\ \text { Edwin Corbett, } & \text { Daries Davenport, } & \text { W. Egerton, } \\ \text { John Ford, } & \text { John Clegg, } & \text { Egerton Leigh, } \\ \text { Thomas Parker, } & \text { Edward Stracey, } & \text { E. V. Townsend, } \\ \text { Trafford Trafford, } & \text { T. W. Tatton, } & \text { R. Wilbraham, } \\ \text { John Brown, clcrk. } & \text { J. T. Law, clerk, } & \text { J. H. Mallory, clerk. }\end{array}$

On the 13th of August, before the Rev. W. R. Hay, " Jonathan Andrew, of Manchester, maketh oath and saith that, on Thursday evening, the 12th inst., betwixt the hours of eight and nine o'elock, he saw exercising on the new roal to Rochdale from twenty to twenty-five men, armed with staves, from four to five feet long, and apparently from three to three and a half inches round, similar to a brush-stail, but chiefly of green wood. He heard the word of command given (by a person separated from the rest), 'March,' 'Halt,' \&c." Poor Jonathan! Drilling in the open public road with mop-stails of green wood must have had a formidable appearance indeer. Why did he not swear that he also was alarmed? With all these depositions as to drilling, and oaths of people that they were afraid for their personal safety, the magistrates were not sure that they had yet made all right. At midnight of the 15 th of August they were yet in uncertainty as to their power of preventing the meeting to be held next day. Mr. Norris, in a letter to Lord Sidmouth, dated eleven o clock, p.m., says that although the magistrates, as then adrised, clid not then think of preventing the meeting, they were alarmed, and were in a state of painful uncertainty. Can it be that while thus writing to Lord Sidmouth, officially, there was a private resolution, perhaps directed by him, to allow the meeting to assemble and to disperse it with the swords of the yeomanry, notoriously known to have been sharpened for the occasion? On the very evening on which Mr. 
Norris wrote, Hunt had offered to surrender himself voluntarily. Did the magistrates, as Dr. Taylor supposes, rather seek the opportunity of striking terror into the multitude assembled by arresting their leader, no matter at what risk of bloodshed, before their eyes ?

If, at eleven o'clock on the night of the 15th August, the magistrates did not think of preventing the meeting -did not think that the meeting could, legally, be prevented-the inhabitants could not buit suppose that it would pass off peaceably, as other previous meetings had passed off; and, on going to sleep, probably not one in a hundred of them had the slightest apprehension that they would encounter any danger in attending it themselves and taking their wires and children with them. There was more fear throughout Manehester, on the night of the 15th August, that the next morning would be rainy, than that the peace would be broken by either the people or the magistracy. 


\section{CHAPTER XI.}

TIE SIXTEEXTH OF AUGUST, 1819.

THE morning of the 16th of August came, and soon after nine o'clock the people began to asscmble. From the windows of Mr. Baxter's house in Mosley-street, I saw the main body procecding towards St. Peter's Field, and never saw a gayer spectacle. There were haggard-looking men certainly, but the majority were young persons, in their best Sunday's suits, aud the light coloured dresses of the cheerful tidy-looking women relieved the effect of the dark fustians worn by the men. The "marehing order," of which so much was said afterwards, was what we often see now in the processions of Sunday-school children and temperance societics. To our eyes the numerous flags seemed to have been brought to add to the picturesque effect of the pageant. Slowly and orderly the multitudes took their places round the hustings, which stood on a spot now included under the roof of the Free Trade Hall, near its south-enst comer. Our company laughed at the fears of the magistrates, and the remark was, that if the men intended mischief they wonld not have brought their wives, their sisters, or their children with them. I passed round the outskirts of the meeting, and mingled with the groups that stood chatting there. I oceasionally asked the women if they were not afraid to be there. and the usual laughing reply was-" What have we to be afraid of:" I saw Hunt) arrive, and heard the shonts of the sixty thousand persons by whom he was enthusiastically welcomed, as the carriage in which he stood made its way through the dense crowd to the hustings. I proeecded to my dwelling-louse in Salford, intending to return in about an hour or so to 
witness in what manner so large a mecting would separate. I had not been at home more than a quarter of an hour when a wailing sound was heard from the main street, and, rushing out, I saw people running in the direction of Pendleton, their faces pale as death, and some with blood trickling down their cheeks. It was with difficulty I could get any one to stop and tell me what had happened. The unarmed multitude, men, women, and children, had been attacked with murderous results by the military.

The magistrates had resolved, at the last moment, that Hunt, and the friends who accompanied him to the hustings, should be apprehended in the face of the mecting. It was a great asscmblage, and, no doubt, they thought the capture of the ringleaders in the presence of sixty thousand persons would produce a salutary effect. There was abundance of force at hand to render resistance hopeless. The number of special constables had been greatly increased, two hundred additional having been sworn in for the occasion; a portion were stationed round the hustings, and another formed a line of eommunication thenec to the house in which the magristrates were assembled, a distance of about a hundred yards. Near to the field, ready the moment their services were required, were six troops of the 15th Hussars, a troop of horse artillery, with two guns, the greater part of the 31 st reginent of infantry, some companies of the 88th regiment, the Cheshire yeomanry, of between three and four hundred men, and the Manchester yeomanry, of about forty, the latter hot-headed young men, who had volunteered into that service from their intense hatred of radicalism. With such a foree at command, the warrant might have been executed without the slightest tumult. Had Nadin, the deputy eonstable, a man of more bluster than eourage, been afraid to proceed along the line of constables, a few men from the regular army might have formed an additional line for his protection. No such intention was indicated; IIunt had addressed the dense multitude, now hushed into 
deep silenee, intently listening to the opening of his speech, when, suddenly, at a quick trot, past the corner of a wall which bounded Brown's cottage, appeared the Manehester yeomanry, and drew up in front of the house in which the magistrates were met. The erowd reecived them, as Bamford says, with a shout of good will-as the aggressors said, with a shout of defiance, when, as suddenly as they had appeared at the outskirts of the meeting, they drew their swords, wared them round their heads, and dashed into the crowd! Nadin had said he was afraid to serre the warrant, and this was the way it was to be serred. As the yeomanry neared the hustings the incrt resistance of those who could not move out of the way increased, and the troops were separated, each man striving to open out his own way, some with pale faces and firmly-elosed eyes, striking with their sabres as if they were insane. At this time two squadrons of the hussars eame upon the field. Sir W. Jolliffe, who, was a lieutenant in the regiment, says:- "It was then, for the first time, that I saw the Manchester yeomanry; they were seattered singly or in small groups, over the greater part of the field, literally hemmed up, and wedged into the mob, so that they were powerless either to make an impression or to escape; in fact they were in the power of those whom they were designed to overave; and it required only a glanec to discover their helpless position, and the neeessity of our being brought to their rescue." The attack was then ordered. The hussars, in their turn, and with resistless foree, dashed into the crowd. " People, yeomen and constables," says Sir W. Jolliffe, " in their confused attempts to eseape, ran one over the other, so that, by the time we had arrived at the end of the field, the fugitives were literally piled up to a considerable elevation above the level of the field." The reseued yeomanry were not satisfied with a eharge which had produced this frightful effect. Bamford says :-

"On the breaking of the erowd, the reomanry whecled; and 
dashing wherever there was an opening, they followed, pressing and wounding. Many females appeared as the crowd opened; and striplings and mero youths were also found. Their crios were piteous and heart-rending; and would, one might have supposed, have disarmed any human resentment; but their appeals were vain. Women, white-rested maids, and tender youths, were indiscriminately sabred or trampled on; and we hare reason for beliering, that fow were the instances in which that forbearance was rouchsafed which they so earnestly implored. In ten minutes from the commencement of the havoc, the field was an open and almost deserted space. The sun looked down through a sultry and motionless air; the curtains and blinds of the windows, within view, were all elosed. A gentleman or two might occasionally be seen looking out from some houses of recent crection, near the door of which a group of persons (epecial constables) were collected, and apparently in eonversation; others were assisting the wounded, or carrying off the dead. The hustings remained, with a fow broken and hewed flag-stares erect, and a torn or gashed banner or two drooping, whilst over the whole field were strewed eaps, bonnets, hats, shawls, and shoes, and other parts of male and female dress, trampled, torn, and bloody. The yeomanry had dismounted; some were easing their horses' girths, others adjusting their accoutrements, and some were wiping their sabres. Several mounds of human beings still remained where they had fallen, crushed down and smothered; some of these were still groaning; others, with staring eyes, were gasping for breath; and others would never breathe more. All were silent save those low sounds, and the occasional snorting and pawing of stceds. Persons might sometimes be noticed peeping from attics, and over the tall ridgings of houses, but they quickly withdrew, as if fearful of being observed, or unable to sustain the full gaze of a scene so hideous and abhorrent."

Hunt and his companions on the hustings had been taken into custody during the enactment of this frightful tragedy.

Sir W. Jolliffe says:- "The hussars generally drove the people forwards with the flats of their swords; but sometimes, as is almost invariably the ease when men are placed in such situations, the edge was used both by the hussars and, as I have heard, by the yeomen, but of this latter part, I was not cognizant; and believing though I do that nine out of ten of the sabre wounds were caused 
by the hussars, I must still eonsider that it redounds to the humane forbearance of the men of the 15th that more wounds were not reeeired, when the rast numbers are taken into eonsideration with whom they were brought into hostile eollision." Collision is not exactly the term to deseribe an action where the striking was all on one side. Every blow was an unnecessary one, for no resistance was ever attempted. Subsequent inquiry proved that the yeomanry had a larger share in the infliction of sabre wounds than Sir W. Jolliffe attributes to them, and to them alone the dishonour attaches of having wounded several peaceable persons on the adjacent streets after the dispersion of the meeting.

It was known that some of the reporters who were on the hustings, amongst them Mr. Tyas, of the London Times, when the sanguinary attaek was made upon the assembled multitude, had been taken into custody, and it was feared that no relation of the erents would reach London, exeept what might be sent by directions of the magistracy, and coloured to justify their eonduet. Mr. John Edward Taylor undertook to write to one London paper that erening, and I to another. Our narratives appeared in print on the following day, and bearing greater internal evidence of truth, they received credence in preference to the accounts sent to government and the government press, and raised a strong feeling of indignation, which was deepened in intensity, and spread to all parts of the kingdom, when the reporter of the Times, reseued from duranee, eorroborated all our statements, and added details of still deeper atrocity than those which we had described.

The Manchester magistrates, alarmed at the tone of public opinion in London, had a meeting, hastily convened, on Thursday, the 19th, at the police-office, adjourned thenee to the Star Inn, where it might be safe from the possibility of intrusion on the part of any police commissioner, who might hold the opinion that a peaceable 
assembly ought not to have been dispersed by the sword. Resolutions, as if adopted at a public meeting, were passed and published, thanking the magistrates and the soldiers. I have mentioned that, from the time of the "blanket meeting," reform principles had been making gradual progress amongst the middle classes, disgusted by the arbitrary and the tyrannieal, though cowardly, proceedings of the Sidmouth administration. The dispersion of a legallyconvened meeting aroused a gencral indignation, which proved that the old doetrine of non-resistanee to arbitrary power was on the wane; and the smuggled passing of thanks, so dishonestly sent forth, occasioned an expression of public feeling and opinion, such as had never been manifested in Manchester before. The following DECLARATION and PROTEST against the Star-Inn resolutions was immediately issued :-

"We, the undersigned, without individually approring of the manner in which the meeting ledd at St. Peter"s, on Monday, the 16th of August, was constituted, lereby declare, that we are fully eatisfied, by personal observation or undoubted information, that it was perfeclly peaceable; that no seditions or intemperate harangues were macle there; that the Riot Aet, if read at all, was read privately, or scithout the knoucleslge of a great body of the meeting; and we feel it our bounclen duty to protest against, and to express our utter disapprobution of, the unexpected and nnnecessary irolence by which the ussembly was clispersed.

"We further declure that the meeting convened at the Police Oflice, on Thursday, the 19th of August, for the purpose of thanking the magistrates, municipal oflicers, soldiery, de., was strictly and exclusirely pricate; and in order that its privacy might be more completely ensured, was adjourned to the Star Inn. It is a matter of notoriety that no expression of dissent from the main object of the meeting was there permitted.

"We, therefore, deny that it had any elaim to the title of a "numerons and highl! respectnble meeting of the inhalitants of Manchester and salford, and their neighbourhood; and we hereby invite those who have presumert so to style it, to join with us in giving to the inlubitants at large of Mfanchester and Salford, and their neighbourhood, a public opport unity of expressing their real opinions upon the subject." 
In the course of two or three days this protest received four thousand cight hundred signatures, including those of a considerable portion of persons who, in ordinary parlance, would be spoken of as belonging to the "respectable classes." It may gratify sons and grandsons to see some of the names attached to this declaration, at a time when there was some danger incurred by the expression of any opinion adverse to the powers that were :-

T. B. W. Sanderson, Edward Baxter, John Reeres, William Wright, Samuel Hobson, John IIobson, Samuel Winks, John Robinson, Richard Potter, Henry Pope, John Brooks, Joseph Weight, Joseph Manson, John Radeliffe, William Harrey, Thomas Johnston, John Johnston, Jonathan Lee', Joln Harrison, Joseph Gallemore, James Anderson, R. W. B. Sanderson, Benj. Holbrooke, Isaae Lees, John Swindells, Thomas Wilkins, James Oceleston, Samuel Livesey, James Bates, Joln Richurdson, William Wood, John Jitchell, M.D.,
Thomas Steren, Joln Smedley, J. S. Ormerod, Riehard Woodward, William Tuer, Peter Tuer, Joln Shuttleworth, Hez. Wright, W. Norris Buckley, Jolm Barlow, John Asliton, Jesse Gallemore, William Shaweross, Jolın Braddock, William Cantrel, John Ifayes, John Atkinson, William Sutcliffe, James Kershuw, J. E. Taylor, J. B. Thompson, Joln Fleteher, John Kenworthy, F. R. Atkinson, Arclibald Prentice, Benjamin Beddome, Peter Coe, George Johnston, William Gadsby, Henry Grimsliaw, John Mangnall, Stephen Bates,
Henry Moore, Francis Jackson, George Horrocks, William Johns, Samuel Bates, Robert Askew, Joseph Anthony, Joseph Hawkes, Thomás Jones, William Ryley, William Barlow, Edmund Lord, Jeremiah Turner, Samnel Pullein, John Grundy, Thomas Reed, John Gallemore, Thos. Tipping, jun., Jeremiah Buckley, Daniel Lonsdale, Thonias Hopkins, Joseph Wood, George Woollam, Richurd Wilson, Thomas Kershaw, Alexander IIaliday, Robert Wright, Josepl Woodward, Charles Pollitt, John Dewhurst, John Johnson, Johu Blackslaaw, 


$\begin{array}{lll}\text { William Barratt, } & \text { J. R. Taylor, } & \text { William Harrison, } \\ \text { Joseph Barratt, } & \text { John Foster, } & \text { Thomas Grundy, } \\ \text { Edmund Wilson, } & \text { Franeis Wood, } & \text { William Spencer, } \\ \text { William Clarke, } & \text { William Swindells, } & \text { J. G. Robberdo, } \\ \text { Edward Foulkes, } & \text { Thomas Oakden, } & \text { J. S. Grafton. }\end{array}$

By way of counteracting the effect of this energetic protest, on the 27th of August Lord Sidmouth communicated to the Manchester magistrates, and to Major Trafford, and the military serving under him, the thanks of the Prince Regent, " for their prompt, decisive, and efficient measures for the preservation of the public peace" on the 16th instant. This haste to thank the delinquents greatly added to the exacerbation of the public mind. On September 2nd a large meeting was held at Westminster, at which Sir Francis Burdett presided, and a remonstrance to the Regent was adopted, calling on him to order the prosecution of the Manchester magistrates by the law officers of the erown. Meetings were also held in the city of London, at Glasgow, York, Bristol, Liverpool, Norwich, Nottingham, and other large towns, to address the Regent on the same subject. Some petitioned for inquiry; others passed a strong censure on the Manchester authorities and the ministers who had advised the royal letter of thanks. It was as the breaking up of a great frost. The middle classes had appearel as if they were bound up in the icy chains of indifferenee to the demands of their humble fellow-countrymen for their fair share of representation; but the sudden outburst showed that whatever opinions they might hold, as to how far the eleetive franchise might safely be extended, they were not disposed quietly to witness death inflicted on men whose only erime had been, that they asked for universal suffrage, rote by ballot, annual parliaments, and the repeal of the corn law.

Meanwhile hundreds of persons wounded upon that fatal 16th of August were enduring dreadful sufferings. They were disabled from work; not daring to apply for parish 
relief; not eren daring to ask for surgieal aid, lest, in the arbitrary spirit of the time, their acknowledgment that they had reecired their rounds on St. Peter's Field might send them to prison-perbaps to the seaffold. A subscription was entered into for their relief; a careful and rigid inquiry was made for many suecessive weeks, the committee meeting in $\mathrm{my}$ warehouse, then in Chureh-street; and thus we arrived at an approximation to the extent of death and calamity inflicted. The published statement of the committee, at the conclusion of that long and careful inrestigation, records the deaths that had oecurred :-

John Ashton, Cowhill, Oldham; sabred.

John Ashworth, of the Bull's Head, Manehester; sabred and trampled on.

Thomas Buckley, Baretrees, Chadderton; sabred and stabbed.

William Dawson, Saddleworth; sabred, erushed, and killed on the spot.

Fildes, Kennedy-street, Manehester, an infant; rode orer by the caralry.

John Lees, Oldham; sabred. A eoroner's inquest leld on the body, adjourned without a verdiet.

Arthur O'Neill, Pigeon-street, Manehester; inwardly erushed.

Martha Partington, Fceles; thrown into a cellar and killed on the spot.

Joseph Whitworth, Hyde: shot.

James Crompton, I3arton; trampled on by the eavalry.

Mary Ileys, Osford-strect, Manchester; rode over by the caralry.

The names of the wounded, their ages, their places of residenee, the manner in which they received their hurts, and the amount of pecuniary relief which they receired, are also given in the published report of the committee. Their number was foun IU XDREn AxD TwExTy, and the deputation from London state, that at the time they made their report, there were still OXE IIUXDRED AXI FonTy CAsEs to be considered by the loeal committee, which continued its meetings till these cases were investigated and relief aduinistered. The deputation, Messrs. Rayner and 
Hall, report to the central committee that out of four hundred of the sufferers whom they risited and relieved, one hundred and thirteen were females, being the mothers, wives, sisters, and children of many of the persons who attended that menorable meeting; that out of those four hundred and twenty persons materially injured, one hundred and forty received severe sabre cuts, and fourteen of these were inflicted on females; and that a great number of the sufferers had declared, "that if their respective parish offeers had then been aequainted with the injuries they had sustained by attending the Manchester meeting, they would have been deprived of aid when their sufferings more particularly demanded it." The deputation further remark, that "they could not observe but with surprise the very general fear and dislike that the sufferers manifested against applying for medical relief to the Manchester Infirmary, not from any appreliension that their wounds and injuries wonld have been neglected or unskilfully treated, but they themselves would have been huffed and insulted on account of their politieal principles." As to the condition of the sufferers, the deputation report: "As the visits of your deputation were made unexpectedly, and frequeutly at those hours when these poor people were preparing or partaking of their hard and scanty meals, they had therefore ample opportunities of observing that their sole subsistcuce was potatoes, with a small quantity of salt, measured out in inadequate quantities to each individual of the family. Here and there was to be seen a little fat or dripping mixed up with the potatoes; but in no instance among the weavers did your deputation see a morsel of animal food; and they aseertained, that in most families where there were children, the taste of meat was unknown from one year to another."

Eleren persons killed; six hundred wounded; sixty thousand carrying to their homes the recollections of that fatal day; poverty and misery in every cottage; deep 
distress, attributable, not unjustly, to heary taxation and a law prohibiting the importation of food. Was there no wild revenge for the injuries inflieted-no vengeanec on the instruments of an iron-handed government-no retaliation with the dagger for the eruel and wanton assault by the sword? There was not. The population of Iancashire had faith in the just administration of the law. Its working men, rough in manner and rude in speech, but slirewd, intelligent, and possessing nueh of the generous qualities of the Anglo-Saxon race, would not stoop to cowardly assassination. They had faith in their principles and greater belief in moral than plyysical force. On the day after the fatal sixtcenth of August, the consciences of the guilty conjured up armies of deeply-enraged men, marehing on Manchester, and devoting it to destruetion. Thirty thousand pikemen were said to be actually on their road from Oldham alone! In that paralysis of terror, anything might have been done. But the men of Laneashire would not seck reform through the horrors of a sanguinary rerolution. The belicf was strong amongst them that bloodshed had nerer added much to the amount of liberty; they had no faith that freedom could be snatehed as a brand from the flames of eivil war. There was no armed attack; no private exereise of wild revenge. Reverend W. R. Hay, who was rewarded with a living of $£ 2,400$ a year for his services in "putting down" the Reformers; Reverend W. C. Ethelston, whose reading of the Riot Aet nobody erer heard; stipendiary magistrate James Norris, who sought from gorernment a power beyond the existing law; Hugh Hornby Birley, who led the attack upon a defeneeless multitude; Joseph Yadin, who harshly apprehended those who were to be harshly punished under judge-made law ; all these have gone to their graves, without an assault, without an insult.

The subseription was for a double purpose-to relieve the sufferings of those who, being wounded or bruised, had 
been deprived of the means of obtaining bread-and to proteet and defend the persons who had been arrested. At the date of the report, 14th of February, 1820, the sams distributed to the sufferers amounted to $£ 1,20613 \mathrm{~s} .8 \mathrm{~d}$. ; there had been expended $f 1,077$ 6s. 9d. in law charges; and there was a balance on hand of $£ 768$ 1s. 9d. towards the expenses to be incurred at the approaching assizes, and the relief of the persons. whose cases had not yet been fully investigated. The amount of the subseription proved that a deep sympathy for the oppressed and injured reformers prevailed amongst the middle elasses, an inference which Mr. Bamford has omitted to draw, though he has made grateful notice of acts of individual kindness to himself. It was a healthful sign of the times, which should not be passed over in silence; for sympathy with reformers gave the promise of co-operation in the work of reform; and from this period may be dated a marked and farourable change in the current of public opinion.

Amongst the recipients of pecuniary aid were the persons who were imprisoned along with Mr. Hunt, who each had ten pounds. They were: Mr. Joseph Johnson, brushmaker, of No. 17, Shudehill, Manchester, the host of Hunt; indomitable old John Knight; Mr. Moorhouse, a coach proprictor, of Stockport; Mr. Saxton, the printer of the Manchester Observer; Samuel Bamford, of Middleton, the poet of radicalisn ; Healey, of Lees, near Oldham, commonly ealled Doctor Ilealey; Jones, Swift, and Wilde; and Mrs. Gaunt and Mrs. Hargreaves. Five persons against whom bills had been found for having been on the field on the 16th of August, and who had been confined five months for want of bail, received amongst them f28 10s. Twenty-nine persons, inprisoned for various offences, but against whom no bills were found, received amongst them $\mathrm{f} 4 \mathrm{i}$. The following are a few extracts from the report, as a specimen of the various cases in which relicf was given:-Margaret Booth, dreadfully crushed in 
the crowd, disabled nine weeks, still (February, 1820) unwell, $£ 3$. James Beswick, severe sabre cut on his elbow, and trampled on by the erowd, disabled seven weeks: - he had held up his arm to save his head, £2. William Butterworth, of Stake Hill, near Middleton, a desperate cut on the right arm, just below the shoulder,

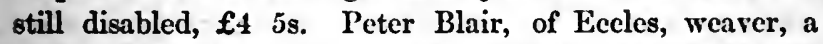
severe sabre cut on his right shoulder, knocked down and bruised, £2. Thomas Billington, of Chapel-street, Ardwick, severe sabre cut on the top of the head, which went to the skull, and both arms bruised; he was repeatedly chased round the yard of the Friends' mceting-house, and receired this cut on going out of the gate, $f 1$ 12s. Thomas Blinstone, aged 74 years, Back Turner-street, both arms broken, and much bruised in the body (disabled for life), assisted to remove to his parish, $f 2$. I need not multiply instances, but I may add that amongst the other wounded were-a man aged 61 , four 60 , two 64 , one 67 , one 65 , two men 50 , a man 70 , a woman 55 , one 63 , three men 63 , a man 76 , one 69 , a woman 64 , one 67 , one 74 , a man 75 , a man 66 , one 61 , a woman 71 , a man 62 (disabled for life), a woman 70 , one 66 , one 79 , a man 74 , one 75 , a woman 64 , and so on. Poor old Thomas Blinstone was looking on at the outside of the crowd when the yeomanry, turning round the wall, rode over him. I recollect him standing in my counting-house, with his two arms splintered up, and telling his case to the relief committee. At the conclusion he said, "and what is wur than aw, mesters, they'n broken my spectacles, and aw're ne'er yet been able to get a pair that suits me." 


\section{CHAPTER XII, \\ SUBSCRIPTIONS AND SUBSEQUENT TRIALS.}

Asroxgst the subscribers to the find for the relief of the indigent sufferers on the 16th of August, 1819, was the Duke of Hamilton, lord lieutenant of the county of Lanark. A snow storm in January, 1820, which, for a time, levelled all distinctions of rank, brought the premier peer of Scotland and myself together at Berwick-on-Tweed. A few days before, one of the London ministerial newspapers had published a most abusive attack upon him, in which it was asserted that the money, instead of being distribited to mitigate the sufferings of those who had been wounded on that occasion, was given to excite further disaffection to the government. The duke was glad to hear, on the authority of one of the Manchester committee, a native of Lanarkshire, whose family was known by him, that substantial relief had been given where it was much needed, and he listened with dcep attention to my narrative of the events of that fatal day. IIe said that, after the forcible dispersion of the meeting, he had been much afraid that the irritation occasioned would give rise to some tumult in his own county, and that he had written to Lord Sidmouth, representing the danger of adding to the existing irritation, calling his attention to the extreme distress that was endured in his neighbourhood-a distress that was more likely to increase than diminish - and suggesting that, in any measure to repress tumult, great care should be taken to discriminate between those who were urged by misery and those who intended to excite to mischief. On his saying that the concession of some reform would be more likely to tranquillize the country than coercion, I rentured to ask how 
far he would extend the suffrage. He said he would give a. vote to all who paid direct taxes. I acknowledged that this would be a very important movement in advance, but that it was liable to the objection that a great part of the revenue of the country was raised by indirect taxation. "Would you," I asked, "tax the necessaries of life-the poor man's bread for instance-and allow him no vote?" "Sir," he said, "that is not legitimate taxation-it is extortion, which ought not for a moment to be permitted." "Well, my lord," I replied, there certainly would be less discontent in the country, if all who are excluded from the right of voting were exempted from the payment of taxes."

The duke expressed a desire to know how the whigs were estimated amongst the active-minded men of the manufacturing districts. I said that there had been a great disposition to rely upon them as the friends of progression, but that their reluctance to come out in favour of a bold amendment of the representative system, had greatly diminished the confidence of the people in their professions of regard for popular rights, and that the degree of confidence which remained would diminish till none was left, unless some forward movement was made. The duke said that the whigs were disposed to more onwards, but that they wished to carry the Grenvilles with them. "You had better leave them behind you than wait for their advance," I said; "they are nothing as a party; they hold you back when you should advance, and thus deprive you of the public confidence. Throw them overboard at once; come forward with a proposal for the destruction of the small rotten boroughs,-for the transference of seats to the large and important boroughs, - for shortening the duration of parliaments, - and for extending the suffrage so as to include the intelligence of the country,-for any honest measure which shall give the promise of more in due time, and I am confident that the whole community will be with you, as one man, and with a denonstration of power that will 
compel both tories and Grenvillites to yield all that is demanded." It was not until eleren years after this conrersation that the whigs dil make the move; they were, as I had predicted, nobly and generously supported by the country; and through that support they achieved a victory which promised other victories, if they would use the means. It rould seem now as if there still remained a Grenville party to hold them back. The finality of the reform bill was declared; and from 1832 to 1850 , every attempt to improve its provisions has been resisted as strenuously as the borongh-mongers resisted the destruction of their strongholds; and we have only last ycar been relieved from that tax on bread which the Duke of Hamilton declared; twenty-nine years before, to be an extortion which ought not for a moment to be permitted.

One object of the public subscription was to obtain a decision as to the legal character of the proceedings on the 16th of August. A man named John Lees had died in consequence of sabre cuts and other injuries received that day, and an inquest on his body was opened at Oldham on the 25th of September. Much delay occurred in the commencement of this inquiry by the absence of the coroner, Mr. Ferrand, from his duty, and the refusal of others to act in his stead; and it was afterwards prolonged to an extent unexampled, partly by the number of witnesses brought forward, and partly by the frequent adjournments, ultimately from Oldham to Manchester, which the coroner interposed. It was the aim of the solicitor, Mr. Harmer, afterwards alderman of the eity of London, who conducted the examination on the part of the nest of kin of the deceased, to prove the peaceful character of the meeting, and the nuwarrantable nature of the military attack. On the other side. efforts were made to show that previous acts of violenec on the part of the multitude, and the reading of the riot act, had justified the attack, and exonernted from legal eriminality those connected with it. Ferrand, the 
coroner, not having seen the body of the deceased, Mr. Harmer, on the 2nd of October, suggested the necessity of his complying with the law in that respect, and inquired if he had seen the body, to which Ferrand replied, "I shall give no answer," and, refusing to give any further information on the subject, proceeded afterwards to examine eridence for two entire days, and then, on the middle of the night of Tuesday, the 6th of October, he caused the body to be taken up, without giving any notice to the jury or the relations of the deceased.

After the corouer had seen the body, it was again interred, and he continued the irregular investigation until the 13th of October, when, without any reason assigned, he adjourned the inquest to the 1st of December! It would require very great charity to believe that this adjournment was not made in order that government might in the mean time decide how the matter should be disposed of. The Court of King's Bench was applied to for the purpose of compelling him, by mandamus, to resume and elose the inquiry. The eoroner showed cause against the mandamus, and the court declined interfering, on the ground that he had committed an irregularity, by which the proceedings might be considered as invalid. The coroner, by omitting to observe the law, had placed hinself above the law! If the irregularity had been designed, it eould not better hare served the purposes of the government. Mr. Harmer, in an affidarit intended to form the ground of the other proceedings, which, however, were not taken, says; "That on the said 1st day of December he attended at the Star Inn (Manchester), the place appointed by the said Mr. Ferrand for the jury to meet in and resume their inquiry, but the said Mr. Ferrand did not attend; and this deponent saith that his deputy, Mr. Battye, who was there in his stead, dismissed the jury, by telling them that the inquest was at an end, and their services were no longer required; and this deponent further saith, that when the said Mr. 
Ferrand adjourned the inquest, as before mentioned, there were several witnesses in attendance to give evidence respecting the cause of the death of the said John Lees, but the coroner refused altogether to take the examination of the said witnesses." It had been the boast of Englishmen that the sudden and violent death of the most obscure and wretehed individual could not be passed orer without the strictest investigation of all the circumstances attending such death. In those days it was the privilege of the most obscure and wretched coroner to render the law inoperative.

Amongst the meetings held to protest against the proecelings of the magistracy on the 16th of August, was one of the fiecholders of the county of York, on a requisition to the high sheriff, signed by the Duke of Norfolk, by Earl Fitzwilliam, lord lieutenant of the West Riding, and many other noblemen and gentlemen. "It is worthy of remark," says the Annual Register, "that the reformuers left the whole busisess of the day to be conducted by the noblemen and gentlemen who had come forward to summon the meeting," - a proof that the so-much-abused radicals of the time were quito willing to be silent when they saw persons of station advocating the cause of justice. In consequenco of the part which he had taken in this public meeting, Earl Fitzwillian immediately received from the Prince Regent his dismissal from the office of lord lieutenant, a proceeding which greatly increased the unpopularity of the prince's ministers. Amidst the indignation which prevailed, considerable anusement was created by the issue of the following remarkalle cireular :-

"Whitehall, Norember 6, 1819.

"My Lorl,-Having been inforuned that there are laying about thronghont the kingdom, especislly in the naritime part of it, a great number of munon, which are privite property, a considerable part of which were formurly used in morchants' ships, I beg leare to call 5our loriahipis attention to this subject; and to request that you will direct the angistrates under your lordship's charge, to make the necessary inquiries within their respective districts, and if any gun 
of this description should be found therein, that they will cause immediate steps to be taken, with the consent of their owners, for rendering them useless, or for remoring them to a place of security. "I have the honour to be, \&c. \&c.,

"H. H. Lieutenant of —_." "Sinyortir.

This elegant and grammatical piece of official composition reminds me of a plaćard, or proclamation, issued by the sapient justices, denouncing the intended meeting to be illegal, and yet commanding the people to "abstain from attending the suid meeting at their peril." In allusion to this, Hunt, good humouredly, remarked, that rery likely their elerk being gone to his dinner, the justices had composed this notice themselves, which at once would explain the absurdity of its language; for though a commission of the peace might hare the magical effect of endowing a man with law, it did not follow that it could teach him to write English.

On the 23rd of Norember parliament was opened by the Regent, who was greeted in no flattering manner by the populace. In the lords, an amendment to the address was mored by Earl Grey, with reference to the Manchester proceedings, which were characterised as illegal and unconstitutional, and ably supported by Erskinc, but negatived by 159 peers to 34. A similar amendment, after two days' debate, was negatived in the commons,-150 members voting for, and 381 against, inquiry. With such orerwhelming majorities ministers saw that they could easily carry measures for further coercion. On the 30th of Norember, Lord Sidmouth, in the upper house, and Lord Castlereagh, in the lower, gave an outline of the coercire. measures they had in contemplation in the then state of the country. They aequired the name of the "Six Acts," and consisted of the following bills:-1. To take away the right of trarersing in cases of misdemeanor. 2. To punish any person, found guilty, on a second conviction, of libel, by finc, imprisonment, and banishment (as first introduced 
transportation) for life. 3. For preventing seditious meetings, requiring the names of seven householders to the requisition which, in future, convened any meeting for the discussion of suljeets connected with church and state. 4. To prohibit military training, except under the authority of a magistrate or lord-licutenant. 5. Suljecting cheap periodieal pamphlets on political questions to a duty similar to newspapers. 6. And lastly, a bill giving magistrates the power of entering houses by night or by day, for the purpose of seizing arms believed to be collected for unlawful purposes. These bills were all earried by large majorities. The entering houses by night, and the severity of the restrictions on the press were briefly objected to; but there appeared a general concurrence in the necessity of strong measures. It was desirable to put down the demand for reform, and a boroughmonger's parliament was not slow in giving its aid to a tyrannical administration. The "Six Acts did not effect the intended purpose. They had the effect of repressing the wilder and more violent of the radical orators; but in so doing, they allowed the principles of reform to be more quietly and more calmly considered by nen who would otherwise have been frightened by the fierce front of an intolerant radicalism. In the meantime, many men remained in prison, elarged with the erime of having been present at the meeting of the 16th of August. Their cases will be before us by and bye. It may here be stated, that no time was lost in endeavouring to ereate a prejudice in the minds of the public against those who were doomed to be victims of an arbitrary gorernment, for in a few weeks Fancis Philips issucd a pampliet, which he was pleased to entitle, "An Fixposure of the Cinlumnies circulated by the Fincmic's of Social Order, against the Magistrates and the Yeomanry Cavalry of Manchester and Salford." To counteract this slanderous production, an able work was written and compiled by the late Mr. Joln Edward Taylor, entitled "Notes and Observations, Critical and Explana- 
tory, on the Papers relative to the Internal State of the Country, \&c.; to which is appended a Reply to Mr. F. Philips's Exposure, \&c." Effingham Wilson, London, 1820. Numerous other traets appeared on the subjeet; but this by Mr. Taylor will always be not only an important local reeord, but valuable as containing a detail of the lawless tyranny which" at that time prevailed amongst offieials of all ranks and degrees, from Lord Sidmouth down to the deputy eonstable Nadin. We now eome to the trials.

To the oceurrences of 1819 , the people of Lancashire owe the system of giving regular and full reports in their local newspapers of all important public meetings and law proceedings. Previously, subjeets of great eonsequence were dismissed in a single paragraph. A town's meeting in Manchester would be notieed mueh as follows:- " $A$ large meeting was held in the Bull's Head, on Thursday last, for the resolutions of which see adrertisement in our front page." The agitation kept up by the radicals, and the wanton stretch of power exereised by the Manchester magistracy, had exeited so much attention that the eonduetors of the London press thought it worth their while to send able reporters to the scene of action, and the eagerness with which their descriptions and reports were read, indueed the proprietors of the Manchester papers to take a little more trouble to satisfy public euriosity. From that period the Manehester papers may be referred to for a record of publie erents, coloured according to the politics of each, but yet furnishing materials from which he who takes the pains to aseertain the truth may furnish something like a faithful history. The London Times of the period set the example to the rest of the press, in the fulness and faithfulness of its reports; and in the paper of the 30th of August, it gives a very copious account of the proeecedings on the examination and committal of Henry IIunt and his eolleagues, for their appearanee on the hustings on the memorable meeting of the 16th of August. 
As it had been known that on the 27th of that month the determination of the government-regarding the charges agninst the prisoners would be declared, a great crowd had collected in front of the New Bailey prison, and when the doors were opened the court-house was instantly filled. The only magistrates present were Mr. Norris (chairman), Mr. W. Hulton, Mr. Ralph Wright, Mr. William Marriott, Mr. T. W. Marriott, and the Rev. W. C. Ethelston. The names of the prisoners were called over, and answered in the following order :-Henry Hunt, Joseph Johnson, John Thacker Saxton, John Knight, James Moorhouse, Samucl Bamford, Joseph Healey, George Swift, Thomas Jones, Robert Wilde, and Elizabeth Gaunt. Elizabeth Gaunt answered to her name but feebly, being unable to speak out from a tendency to faint, in consequence of being cut and trampled upon in the field, and having been twelve days imprisoned. The chairman then addressed the prisoners :- "When you were last called up into this court, you were remanded on a charge of high. treason. On remanding you, you were informed that the whole of the evidence had been sent up to London, to be laid before the law-officers of the crown, and in the meantime you were to be detainad. It was not until this morning that a communication was made from government, stating that the law-officers of the crown had, for the present, abandoned the higher charge. This communication was not made to me; but there is a gentleman present, Mr. Ibouchier, who has come with orders to proceed upon a less charge. The charge of high treason is not yet abandoned, but government proceeds against you for a minor offence."

The first witness ealled proved the purchase of two copies of the Manchester Obscrer, one of them containing the announeement of the meeting for the 9th of August.

"Who urged you to purchase the papers ?" asked Hunt. The court would not allow the question to be answered. Hunt again asked-" You purchased the second paper on 
the 14th of August?" The court would not allow the witnese to answer.-Matthew Cowper, the next witness, was designated simply " of Manchester." Hunt asked for his address. The court would not allow the question to be answered. Mr. Hunt,- "Of what profession are you ?" Witness: "I am an accountant."-IIunt : "Is that your own profession?" Chairman: "Don't answer that question." Cowper swore to having scen certain flags and colours, one of them with a bloody dagger; the court would not allow Hunt to eross-examine him.-Richard Owen, a pawnbroker, was then examined, and swore to his own alarm, and his belief that the town was alarmed. Hunt asked him when it had oceurred to him to note down what he had deposed to : The witness refused to answer the question, and the court decided that he was not bound to answer. Other witnesses deposed to having seen the male prisoners on the hustings. The eridence against Elizabeth Gaunt being only that she had been seen on the carriage with Hunt, the solicitor for the crown said he would not press for her prosecution, and she was discharged.

Mr. Hunt then addressed the court, denying that any sedition was intended, and arguing that there was no evidence against them to justify a committal for trial. The magistrates left the court for some time, and on their return the chairman said:- "Henry Hunt, and you all : we sent for Mr. Bouchier, in order that we might again carefully peruse the depositions. It is a most painful duty to me to commit 'you for a conspiracy. We can, however, lay our hands on our hearts and say, we have done our duty. As to the charge of conspiracy, though you might not have aeted all together previous to the meeting, yet in the eye of the law, all those who eommit separate acts, tending to one illegal objeet, are guilty of that crime. Coupling the two meetings together, taking into consideration the manner in which the last was 
assembled, with such insignia and in such a manner, with the black flag, the bloody dagger, with 'Equal representation or death,' you came in a threatening manner-you canie under the banners of deatl, thereby showing you meant to overturn the gorernment. There could be no free diseussion where that flag was unfurled. The charge now is, that of having conspired to alter the law by force and threats. It is an illegal matter, and sufficiently made out, and ealls upon us imperatively to commit you for a trial by a proper jury. It is now our painful duty to commit you to Lancaster Castle. On account of the seriousness of the charge, we shall require you, Henry Hunt and Joseph Johnson, to give bail, yourselves in $£ 1000$, and two sureties in $£ 500$ each, and all the others, themselves in $£ 500$, and two sureties in $£ 250$ each.

Johnson and Moorhouse procured bail, and were liberated. The other prisoners were sent off in hot haste to Lancaster Castle. " From the bar," says Bamford, "I was conducted to the yard of my former cell, where I was joined by several of the other prisoners, and we were asking what we should have for dinner, when an order suddenly came that we were to prepare to set off for Lancaster Castle. Our meal was soon dispatehed, and we quickly bundled up our few things. We were then taken to the turnkey's lodge, and each hand changed, after which we were placed on a fourhorse eoach, in the inside of which were Mr. Hunt, Mr. Knight, Saxten, and Nadin. The outside party consisted of myself, Swift, Wilde, Healey, and Jones, with a number of constables armed with pistols. We were also escorted by a strong detachment of hussars, and thus, amid the huzzas of an immense multitude, we drove off.", On the following night, Hunt and Knight procured bail, and left the others in the Castle. Bamforl, in his "Life of a Radical," deseribes how they spent their time there, and how he was employed from the period of his own release till the trial at York. 
The trial, which lasted ten days, was commeneed at York, having been moved by certiorari from Lancaster, on the 16th of Mareh, 1820, before Mr. Justice Bailey and a special jury. The counsel for the prosecution were Mr. Scarlett, MIr. Sergeant Hullock, Mr. Sergeant Cross, and Mr. Littledale, the leading men on the eireuit. Mr. Holt defended Saxton, and Mr. Barrow was retained for Moorhouse and Jones. The other defendants pleaded their own cause. Mr. Charles Pearson, the late member of parliament for Lambeth, was attorney for the defence.

One of the first points attempted to be proved was the connection of the St. Peter's Field meeting with the drillings on White Moss. It was conceired that if the legal meeting could be connected with the illegal, it would prove that both were illegal! Samuel Morton deposed that he followed the procession which accompanied Hunt and Johnson through Withy Grove; he was on the opposite side of the street when they passed the house of Murray, a gingerbread baker, of Hanging Diteh, the man who had been beaten at White Moss; they hissed as they passed; the mob shouted out that they wanted some White Moss humbugs; the town was very tumultuous, and he was much afraid. A witness named Chadwick swore to the training on the Moss, and that the people in the procession hissed as they passed Murray's house. Murray himself swore that he had been beaten at White Moss, and that the people following Hunt hissed as they passed his house. Shaweross, a elerk in the police-office, deposed that he was beaten at White Moss. A man, named Heywood, swore that on the 16th he saw men, in marching order, coming in the direction from White Moss towards Manchester. On such evidence was it attempted to be shown that there was a conneetion between the drillings on White Moss and the peaceful and legally conrened meeting on Saint Peter's Field !

Further to give that meeting the character of illegality, 
witnesses were ealled to swear that they, were afraid! Roger Entwistle, an attorney, swore that the meeting must hare eonsisted of $100,000 \mathrm{men}$; that they were nearly all of the lower order; and that the meeting was certainly ealculated to excite terror and alarm.-Mr. F. Philips also swore that he was much alarmed, and that he had heard many taunting expressions used on the field to every man who wore a good coat. Mr. Hunt attempted to get from this witness some acknowledgment that the reomanry had attacked the people, but was stopped by the judge.-The Rev. Dr. Smith, of the Grammar Schnol, swore that he was much alarmed, and that he had shut his windows and locked his doors.-Matthew Cowper also swore to his alarn. In cross-examination this witness aeknowledged that he had left his situation in consequence of having taken money from his master's till:-Joseph Mills, a "runner" of Nadin's body, swore that the meeting was calculated to exeite alarm.-Jonathan Andrews, of Harpurhey, deposed as to his own alarm. - Mr. Thomas Hardman and Mr. Joseph Green also spoke to their own fears and apprehensions.-Mr. Hulton, of Hulton, amongst other evidence, swore that he had seen from the window where he stood a number of men, close to the hustings, with their arms locked together. He said, in cross-examination : "I could perceive the persons locked together, because they formed a complete cordon, and were bare-headed. I believe solemnly that these people near the hustings were locked arm-in-arm. I saw them linked, I believe, by the arms. They were close together as they could be, and were distinguished from the rest of the erowd. Though the distance was so great from the hustings as to prevent my distinguishing an individual elevated on the hustings, still I, and others, eould see the persons beneath locked together. I swear this from my own knowledge, and not from what I was told."

Mr. Humt.-Can you, sir, standing in that elevated 
situation, and looking round on the comparatively small number of persons now present, see whether their arms are locked?

When this staggering question was put, which, for the moment, astounded the witness, some elapping took place, both in the body of the court and in the gallery. A person named James Kellenbeck was pointed out and brought before the judge as the man who commenced the clapping. This was proved by two or three witnesses. Mr. Justice Bailey said he would give him time till Monday to make an affidarit in excuse. The prisoner said he was ready to swear that he did not clap, but moved his hands merely to prevent himself from falling. The judge begged of him, in the name of God, not to make such an affidarit, for he saw him distinctly clapping. After a severe reprimand, he was committed till Monday, that he might have time to reflect upon his conduct, and draw up any excuse he might have to offer.

Mr. Hunt.-You will now look round the benches, where that crowd is elevated, one above another, and say whether you can sce what they are doing with their arms?

Witness.-Must I answer that, my lord?

Mr. Sustice Bailey. - You may deelare whether the opportunity you had of viewing the meeting on the 16th of August was better than that which you hare of sceing the people now present.

Wilness. - I liad a much better opportunity of seeing the persons at the meeting than I have of observing those in the court!! (This wituess must have been ten times farther from the hustings than he was from the persons in court.)

Mr. Hint.-Could you see the arms of the persons then?

Wiiness.-I could see them wedged, and, I believe, linked together.

Mr. Iunt.-Could you see any part of their arms?

Witness.-I eould distinetly see the outside men linked. 
Mr. Hunt.-Then, from the appearance of the others, you believe the rest were linked?

Witness.-I have no doubt of it.

The witnesses for the defence wero generally of a more respectable class than those who were called for the prosecution. The following are extracts from their evidence, all proving the peaceable character of the meeting:-

Mr. John Smith, one of the editors of the Liverpool Mercury :- " Iu no case whatever did I see any attempt to resist nor any encouragement to resistance given by $\mathbf{M r}$. Hunt, or any other person, either by word, look, or gesture. I saw no sticks lifted up against the military. I saw no brickbats or stones thrown till the elose of the dispersion, when I saw one stone thrown. If any stones or brickbats had been thrown, or any sticks raised in defiance of the military, I must have seen it. I am more than six feet high, and therefore was enabled to see all that took place. I neither beard any offensive expressions uttered, nor saw any ncts of violence committed by the people, from the time of their assembling to their complete dispersion."Mr. Shuttleworth, now Mr. Alderman Shuttleworth :- " I witnessed several parties pass the Exchange, to go to St. Peter's Field. They were marching with considerable regularity, in the form of a procession, and conducted themselves in an extremely decorous manner. In consequence of the observations which had been made as to the number of sticks carried at previous meetings at Manehester, I determined to count, as aceurately as I could, the proportion on this occasion. I did so in several hundreds, until, indeed, I thought I had a fair average; and the result left no doubt on my mind that there was not one stick to ten persons. The stieks were walking-sticks, such as are usually carried by country persons. Their progress (the cavalry's) seemed to be cheeked by the dense crowd, and this appeared to me to cause in them considerable confusion. I did not observe any of them separated from the rest. 
They appeared in one circular mass. The peoplo did nothing to resist them. I saw them go on the hustings. I saw not a stone, brick-bat, or bludgeon, hurled at them." Mr. John Tyas, reporter of the Times newspaper, who had been taken into custody on the hustings, deposed :- "I recollect an officer went up to Mr. Hunt, with his sword in his hand, and desired him to surrender. He said he would not surrender to a military officer, but if any peace-officer came up he would surrender. Nadin then eame, as it appeared to me, from under a waggon; Mr. Hunt immediately surrendered, after first desiring the people to be quiet. If there had been groaning, hissing, and hooting at the extremity of the crowd, the cheering of those round the hustings would have prevented me from hearing it. I saw no sticks flourished by the people as the caralry approached. Had they been flourished I must have seen them."-Mr. James Brettargh, of Pendleton: "I went to the meeting about twelve-o'clock. When 'God save the King' was played, all the people that I supposed belonged to the meeting took off their hats, but the constables did not take off their hats. Mr. Hunt said, 'If any one create any disturbance, put him down and keep him down.' 'This appeared to be addressed to some one belonging to the hustings. I did not hear him say, pointing to the military, 'There are your enemies; if they molest you, put them down and keep them down.' It was impossible, as the soldiers had not arrived at the time. When the eavalry came in, they adranced at either a canter or a gallop ; they came as fast as they could. 'There were not any stones or bricks thrown at them, nor any sticks thrown at or lifted up against them."-Mr. Edward Baines, jun., of the Leeds Mercury: " My eyes were dirceted towards the cavaliy till they began to adrance towards the hustings. When they had got about ten yards into the crowd, I turned away. I saw no stones or briek-bats thrown, nor any stieks held up against them. I had heard nothing from Mr. Hunt of the 
words 'be firm,' but the words 'give three cheers;' these words were repeated, as were the words 'be firm.' "-Mr. William Nicholson, of Lees: "I saw no difference in the appearance of Manchester on that day, save in one instance, -I saw a public-house with the windows shut; a female servant said they had received orders from the magistrates not to sell any beer on that day. I saw a procession pass; I took notice of their sticks; I think about one to four had sticks; they were for the most part switch sticks."-Mr. Thelwall, a builder : "Nothing that I heard or saw on the 16th of August induced me to believe that my property was in the slightest danger. I was in the northern comer of the field, at the angle opposite to Buxton's house. I saw no attempt to oppose the military. I heard no groanings, hootings, or hissing at them. I saw neither stones, sticks, nor brick-bats thrown at them, or thrown up in the air as they passed. I saw no sticks held up at them."

Mr. Robert Grundy, who had been one of the special constables that day, deposed: "I saw no insult or violence offered to any person whatever. I was surrounded by a thick multitude. The persons around me were aware that we were special constables. Some of the constables showed their staves. I pereeived no insult offered to them."-Mr. Joln Molineaux, lamp manufacturer : "I met my daughter on the ground. She expressed a wish to go, and went with her uncle. My daughter is sixteen years of age. I remained on the field till the meeting was dispersed. My daughter remained with me and my brother-in-law. I saw the military arrive. No opposition was made to the military that I saw. There was no groaning, or hooting, or hissing at them. I perceived nothing done to intimidate tliem. I saw no stones, or sticks, or brick-bats thrown at them, or thrown up in the air."-Mr. James Scholeficld: "The different divisions had bands, which played the air generally called 'Rule Britannia,' and the national anthem of 'God save the King.' When the latter was played, the people, 
for the most part, took off their hats. I felt no alarm, nor did I hear any person express alarm at the meeting. I saw. the military arrive. As the cavalry advanced, the people held up their hats as a sort of guard against the cuttings of the swords. There were no brick-bats, stones, or sticks hurled against them."-The bloody dagger was accounted for by the 48th witness for the defence, William Burns, who swore that he had something to do in making the Bury flag: he made a piece of tin in the form of a feur. de lis, and was to paint it yellow, but not having much time on his hands, be painted it red. It came to him on the Saturday evening late, and not liking to paint it on Sunday, and having no yellow paint by him at the moment, he used red. This was the only reason. - Mr. T. B. W. Sanderson spoke to the peaceablencss of the meeting. He was a merchant in the firm of Sanderson and Co., at Manchester. He was there on the 16th of August, and saw the meeting assemble. He transacted his ordinary business during the whole of the day. He saw nobody that day in apparent alarm, in consequence of that meeting, until its dispersion by the military. -The Rer. Mr. Hindmarsh, of the New Jerusalem chapel, Salford, also deposed to the peaceableness of the meeting: "I remaincd upon the field until the cavalry arrived. I saw nothing before their arrival which excited any fears for the safety of person or property, or the safety of the town; I had not the least idea of any such thing. I saw nothing which, in my judgment, conld excite the fears of any rational, temperate, sober-minded person."

It had been proved by the strongest evidence, not eren attempted to be rebutted, that the meeting of the 16 th of August had been perfectly peaceable. It is worth our while to know clcarly how that perfectly-peaceable meeting acquired the character of illegality which justified the outting down, and trampling upon, unarmed men and defenceless women and children, and exposed thase who attended to a long and rigorous imprisonment. The 
attempt was made, eagerly and vindictirely, on the part of the prosecution, to substantiate a charge of seditious conspiracy, by bringing evidence to establish some remote connection of that assemblage with a meeting that had preriously been held at Smithfield and with the trainings at White Moss; but the judge, Mr. Justice Bayley,* either saw that the cridence was insufficient, or that a conviction on such strained construction of the law would be odious to the country, and he laid the main stress, in summingup, on the use of flags, as tending to incite the assembled multitude. The inscription, "Equal Representation or Death," he said, was highly illegal and seditious if intended to reeommend or imply, by the alternative, that equal representation nust be unconditionally obtained or life sacrificed in the attempt; the inscription "No Corn Laws," if construed as meaning that the people would have no such laws, and would forcibly resist them if enacted by the legislature, must be considered as illegal in an extreme degree; the inscriptions, " $\Lambda$ nnual Parliaments," “Universal Suffrage," "Vote by Ballot," were legal enough as an expression of opinion only, but criminal if intended to show a resolution to obtain these objects illegally; "Taxation without representation is unjust," if meant to imply that it is eriminal and unjust to levy a tax upon any man who had not a dircet share in the representation, had a tendency to exeite contempt of the eonstituted authorities of the realm; "No Boroughmongers," had been an inseription at the Smithfield meeting, and therefore it was bad; the main question was,

- There unver was a man better fitted for the purpose than this judge. His appearance was prepossesshig, tall, slebdor, and grave; mili in manner, but cunzing in etlect, and at the very time he led the preople to suppose he was aiding the priturier, axording to the fureical notion of being his connsel, the wes studiounly cutangling litm in the meshes of special plealing, so as to secure his victim upon the whar prepared by Siducy and Castlereagh. For services thes rendered, thim pius juilga, and editor of an edition of the Book of Common Prager, with notes, which teaches bumility and mercy, was created a Baronet on retiring from the Bench. 
whether such banners and such an assemblage were calculated to excite terror, and if the jury thought so they should give their verdict accordingly.

The jury, after an absence of fire hours, returned to the court and delivered their verdict: "Moorhouse, Jones, Wilde, Swift, and Saxton, xor guirtr. Henry Hunt, Joseph Johnson, John Knight, Joseph Healey, and Samuel Bamford, GUILTY of assembling with unlawful banners an unlawful assembly, for the purpose of moving and inciting the liege subjects of our Sovereign Lord the King into contempt and hatred of the government and constitution of the realm, as by law establisbed, and attending the same."

The whole of the high treason, for which, in the first instance, these men were to be tried-the whole of the seditious conspiracy for which they actually were tried, thus dwindled down into a conviction for having attended a meeting which was only at that moment found to be an illegal one; for, let it be borne in mind that Mr. Norris, the magistrate acting in the name of the magistracy of the district, writing to Lord Sidmouth at eleren o'elock on the night previous to the meeting, declared his conviction that, as the law stood, he believed nothing could be done, on the ground of its illegality, to prevent the meeting being held. If the chairman of the Manchester magistracy, constantly corresponding with Lord Sidmouth, and with all the information that could be obtained from the crown lawyers, declared his conviction, on Sunday night, at eleven o'clock, that he could not regard the meeting to be held on Monday morning as otherwise than one legally convened and legally held-when he regretted that such was the state of the law that the magistrates felt they could not prevent that meeting being held-surely it might have been expected, in the sentence pronounced on the prisoners, that their strong belief of the proceedings being in perfect accordance with the law, would be taken into consideration, and the mildest possible punishment inflicted. But Hunt 
was sentenced to be imprisoned for two years and six months, and Johnson, Healey, and Bamford to one year's imprisonment; and so rigorously was the sentence carried out, that Johnson was not permitted to go, in custody of an officer, to see his wife on her death-bed! The three prisoners in Lincoln jail, elevated by the severity of their sentence to the rank of martyrs, seem to have had no solace from their compulsory association. Bamford takes some pains to show what a fool Healey was; and he complains that when Mrs. Bamford eame to the prison, Mr. Johnson asked her to partake of breakfast with himself and his wife before he told her where her husband was! Of the selfishness of Hunt, confined in Mehester jail, Bamford complains also in the bitterest terms, and loses no opportunity of ridieuling his vanity, egotism, and tom-foolery." Of John Knight he writes in equally disparaging terms. Some friends at Nottinghan had written to Bamford, that if a pound note would be of use to him they would send it. He says, "I thanked them and deelined it, stating at the same time that it would be acceptable to John Knight, at Lancaster Castle, and it was sent to him. But, as I have found, old John would have seen me boiling the stones of the castle wall for dinner sooner than he would have done me, or any one else, a like turn." This sadly lowers the poetry of the martyrdom. 


\title{
CHAPTER XIII.
}

\author{
TIIE RE-ACTIOX.
}

Hituerto the proceedings of the Sidmouth and Castlereagh government had been only against the undistinguished amongst the multitude, or the leaders of the mob-against men whose punishment might be supposed not likely to excite the sympathy of more influential classes. Encouraged by their success - by the great majorities they commanded in both houses-and in the belief that "well-timed rigour" would suppress, at once and for crer, every demand for an amended system of representation, and impelled by the necessity of going on in the eourse commeneed, they soared at higher game. Sir Franeis Burdett was not then at the height of his fame. Cobbett had denounced him as insincere, and he had lost some portion of his former great and almost unexampled popularity. Whether it was to regain his lost ground, or from generous inpulse, he stood forward manfully to denounce the atrocities of the 16th of August, and addressed the following letter, dated the 22nd of August,

\section{"TO TIE ELECTORS OF WESTMIXSTER.}

"Gentlemen,-On reading the newspaper this morning, haring arrived late yesterday eveuing, I was filled with shame, grief, and indignation, on account of the blood spilled at Janchester.

"This, then, is the answer of the boroughmongers to the petitioning people-this is the proof of our standing in no need of reformthese the practical blessings of our glorious boroughmongers' domination-this the use of a standing army in tine of peace. It seems our fathers were not sueh fools as some would make us believe, in opposing the establishment of a standing army, and sending King William's Duteh guards out of the country. Yet would to hearen they bad been Dutehmen or Switzers, or Hessians or Hanorerians, or 
anything rather than Englishnen, who hare done such deeds. What! kill men unamned, unresisting, and, gracious God! women too; disfigured, maimed, eut down, and trampled on by dragoons! Is this England? This a Christian land? A land of freedom? Can such thiugs be and pass by, like a summer eloud, unheeded? Forbid it every drop of blood in every rein that does not proclaim its own owner bastard. Will the gentlemen of England support or wink at suel proceedings? They have a great stake in their country; they hold great estates, and they are bound in duty and in honour to consider them as retaining fees on the part of their country, for upholding its rights and liberties; surcly they will at length awake, and find they hare duties to perform.

"They nerer can stand tamely by, as lookers on, whilst bloody Neros rip open their mother's womb ; they must join the general voice, loudly demanding justice and redress; and head public meetings throughout the United Kingdon, to put a stop, in its commencement, to a reign of terror and of blood; to afford consolation as far as it can be afforded, and legal redress to the widows and orphans - mutilated rictims of this unparalleled and barbarous out rage.

"For this purpose, I propose that a meeting should bo called in Westminster, which the gentlemen of the committee will arrange and whose summons $I$ will hold myself in readiness to attend. Whether the penalty of our meeting will be death by military execution, I know not; but this I know, a man ean die but once, and never better than in viudieating the laws and liberties of his country.

"Exeuse this lasty address. I can senreely tell what I have written; and it may be a libel, or the Attorney-General may call it one just as he pleases. Wheu the seren bishops were tried for libel, the army of James II., then encemped on Hounslow Heath, for supporting arbitrury lower, gare three eheers on hearing of their acquittal.

"The King, startled at the noise, asked, 'What's that?" 'Nothing, sir,' was the answer, 'but the soldiers shouting at theaequittal of the seren bishops.' ' Do you enll that nothing ?' replied the misgiring tyrant, and shortly after abliented the government.

"Tis true, James could not infliet the tort ure on his soldierscould not tear the living llesh from their bones with the eat-o'-nine tails-could not thy them alive. Be this as it may, our duty is to meet; and Fingland expets every man to do his duty.-I remain, gentlemen, most truly and faitlufully, your most obedient servant, "Fuaxcis Berdetr." 
This letter, issued at a time when the public mind was strongly excited, producing a great sensation throughout the country, ministers were foreed from their cowardly policy of attacking only the poor and friendless. They felt themselves compelled to proceed against the higher delinquent. An information was filed against Sir Franeis.by the Attorney-Gereral. Ministers did not dare, howerer, to have the trial in London, where the alleged libel was published. Government had found, on former oceasions, that London juries were not always to be relied upon. The letter had been put into a post-office in Leicestershire, and it was determined that the case should come before a Leicestershire jury, less likely to coutain radical elements than a London one. The trial took place at the Leicester assizes on the 23rd of March. Mr. Denman, counsel for Sir Franeis, contended that there was no proof whaterer of the publication of the letter in the county of Leicester, but the Judge (Best) over-ruled the objection. This overbearing best of judges was afterwards made a lord, and distinguished himself in support of the Orange elubs and other equally creditable affairs. Sir Franeis addressed the jury with great spirit and eloquenee, justified every word he had written, and denounced the conduct of the magistracy as strongly in his speech as he had in his letter. The Leicestershire jury justified the belief of ministers in their subservieney. After a consultation of only two minutes, their foreman stepped into his place and ealled out, "Guilty of libel."

Mr. Denman remarked that the verdiet did not find the publication in Leicestershire. Mr. Sergeant Vaughan contended that it did. Mr. Justice Best then asked the foreman,- "Do you find the libel published in Leicester-" shire ?" To whieh that worthy promptly replied,-_"Guilty of libel in Leicestershire!" The case was argued at great length, in the Court of King's Bench, where the verdict had been impeached, but the result was that Sir Francis 
was sentenced to a fine of $£ 2,000$, and to three months' imprisonment.

Close upon this followed the trial of John Knight, George Dewhurst, Nathan Broadluurst, John Anderson, William Fletcher, John Bury, John Austin, and James Wade, at Laneaster assizes, 1 st of $A_{1}$ pril. The indietment contained twenty-one counts, the substance of which was that they had conspired to go, and eaused others to go, armed to a meeting at Burnley, for the purpose of hindering and obstructing the magistrates and peace-officers in the execution of their duty. The main evidence against them was that Colonel Hargreaves, in making a dash at the procession as it went through Burnley. had carried off a staff which "appeared to hare been prepared for a pike handle ;" and a man (suspected of being a spy) had sworn that he had seen some men (also suspeeted of being spies) with pistols in their possession. The judge, Mr. Justice Bailey, charged that if any person or persons went armed to a meeting, determined if attacked to resist, the meeting was illegal. All the prisoners were convicted with the exception of Wade and Austin, as to whom the prosecution had beer withdrawn. Luder this construetion of the law any meeting night be made illegal. It would need the employment of only two or three spies, who might show each other the pistols they carried.

At the Cheshire assizes, April 10th, Sir Charles Wolseley, Bart., and Joseph Harrison, a sehoolmaster and preacher, were tried for uttering seditious words at a meeting held at Stockport, on the 12th of July. The "open and advised speaking" was not sworn to by any short-hand writer, but on the recollection of persons who had been sent by the magistrates. Amongst the witnesses was Mr. Joln Winterlottom, solieitor. who, a few years ago, underwent the sentence of the court for a more serious offence than the utterance of what the courts at that time ruled to be seditious words. The eridence was from the memory of the 
wituess. Mr. Pearson tried the extent of Mr. Winterbottom's memory, by reading a part of Harrison's speech as reported, and asking him to give the eourt the substance of what was read, but the witness confessed his inability to do so. On such testimony as this it was shown that the ministers of the erown had been abused,-that it had been declared that the Ilouse of Commons dicl not represent the people,-and that Sidmouth and Castlereagh had employed spies, and therefore ought to be detested. On similar testimony it was shown that some men had sticks, and that a coustable, one of "Nidin's rumner's," had been knoeked down on pretence that he was a spy. Of course the defendants were found guilty.

Joseph IIarrison was again indieted, at Chester, on April 18th, for having, in a sermon, preached at Stockport, on Sunday, the 15th of August, unlawfully, seditiously, and with intent, se., uttered the following words: "That the government had starved the people, and it was right that the people should starre the government." "That the commons' house was the house of assembly of the people, where their rights should be protected; but that, when the people asked for their rights, they threatenel to make war upon them." "Can laws proeceding from such a source be called the laws of the land? or is it fit that they should be obeyed?" The principal witness was not a short-hand writer, but a Mr. 'Thomas Cowper, an accountant, who had made himself somewhat notorious by his evidence on IIunt's trial at York. Jien he had not taken notes at the time, but had written them at the Bulkeley Arms, for the use of the Manchester magistrates. It turned out that the starving of the government meant only that people should abstain from beer, spirits, and otlser exciseable commodities. He was found guilty. IIe was then put on his trial again, upon another indietment, and one witness, who was very drunk, and was several times reproved by the court, certainly swore to very seditious words. The jury, believing the drunken 
witness, found the defendant guilty. For the first offence lie was sentenced to twelve months' imprisonment, and for the second, to commence after the first period had terminated, another imprisonment of twelve months!

Previous to this trial the illustrious Jeremy Bentham had published a pamphlet, in which he argued that unless every thing charged in an indictment was proved, the jury should bring in their verdict " not guilty." Harrison was charged with a false libel on the government and the House of Commons, in calling them tyrannical. The jury were sworn to give a true verdict, according to the evidence; there was no evidence that the libel was a false libel; and, therefore, he might hare claimed an acquittal. But Harrison made a monotonous and tiresome speech of four hours' length, wearying out the patience of the jury, when he should have been con rincing their judgment ; and probably their verdict was given more on a consideration of what he said, there and then, for which he was not on trial, than on the evidence that the drumken witness had given. We shall come to cases hereafter in which juries rejected the dicta of courts, that charges of falschood and malice were mere words of course, and needed no proof. The period of the radical agitation was the grand reign of judge-made law.

The tory ministers, rejoicing in the convictions they had obtained in the courts of law, did not lose the opportunity of congratulating the country on the suppression of sedition, and of assuring it that there was no nation in the world which enjoyed so much liberty and happiness. The following passages from the king's speech, at the opening of parliament, on the 27 th of $A$ pril, 1820 , reminds me strongly of what a whig administration said of the prevention of a great rebellion on the 10th of $\Lambda$ pril, 1848 :-

" My Lords and Gentlemen,--

"Deeply as I regret that the machinations and designs of the disaffected should have led, in some jarts of the country, to acts of open riolence and insurrection, I cannot but express my satisfaction 
at the promptitude with which those attempts have been suppressed by the rigilance and activity of the magistrates, and by the zealous co-operation of all those of my subjects whose exertions have been put forth to support the authority of the laws.

"The wisdom and firmness manifested by the late parliament, and the dae execution of the laws, hare greatly contributed to restore confidence throughout the kingdom, and to discountenance those principles of sedition and irreligion which had been disseminated with such malignant persercrance, and poisoned the minds of the ignorant and unwary.

"I rely upon the continued support of parliament in my determination to maintain, by all the means entrusted to $\mathrm{my}$ hands, the public safety and tranquillity.

"Deploring, as we all must, the distress which still unhappily prevails among many of the labouring classes of the community, and anxiously looking forward to its remoral or mitigation, it is, in the mean time, our common duty effectually to protect the loyal, peaceable, and the industrious against those practices of turbulence and intimidation by which the period of relief can only be deferred, and by which the pressure of the distress has been incalculably aggravated.

"I trust that an awrakened sense of the danger which they have incurred, and of the arts which have been employed to seduce them, will bring back by far the greater part of those who have been unhappily led astray, and will revive in them that spirit of loyalty, that due submission to the laws, and that attachment to the constitution, chich subsists unabated in the hearts of the great body of the people, and which, under the blessing of Divino Providence, have secured to the British nation the enjoyment of a larger share of practical freedom, as well as of prosperity and happiness, than have fallen to the lot of any nation in the world."

If this had been indicted as the eomposition of any of the persons previously convicted, any Yorkshire, Leicester, or Cheshire jury would have found the writer guilty of blasphemy, and of intending to bring the government into contempt and ridicule.

We are now arrived at a period when the forced silence of the radicals gave men in the middle classes an interval of calm, in which they could quietly consider the defects of our representative system, undisturbed by the agitation 
which had raged around them. There ean be no doubt that the harsh sentenees which had been pronounced in 1820 had struck terror into the hearts of the noisy demagogues, who, out of their very cowardiee, had thundered out their recommendation by physical foree. In their holes and corners they thought of Hunt, immured in Ilehester, and of Bamford, Johnson, und Healey, in Lineoln jail, none of them eren accused of recommending an appeal to arms; and they wisely resolved to keep out of the way of danger. Yet radicalism was not extinguished, not even damaged, by the compulsory calm. Instead of great meetings, where noisy braggarts usurped the place due to the intelligent and thoughtful men who represented the better part of the industrial classes, there were the little congregations of the workshop and at the fireside, at which the principles of representation were ealmly diseussed, and comparatively sound opinions formed, as to what ought to be the real objects of a government. Amongst the middle classes, also, the condition of the country became the subject of deep consideration, and many were convineed that tranquillity could not be expected in a eountry where nine-tenths of the community possessed not even a shadow of representation. Besides, the blind old loyalty, which had made men respeet authority even when they did not fully approve of its exercise on some occasions, was greatly shaken. Pitt, whose tyranny had an air of some greatness in it that inspired awe, was dead; and his successors, in their mingled timidity and cruelty, inspired contempt and hatred, rather than respeet and fear. George the Third, whose regard to the deceneies of donestic life had kept alive, in spite of his waste of human life and of treasure, some of that attachment to royalty in the abstract, which had been a characteristic of the people during his long uccupation of the throne, now slept with his forefnthers, and a son reigned in his stead, whose undisguised extraraganec, voluptuousness, and profligacy, gave rise to almost 
unirersal disgust. Men began to think what loyalty meant when royalty no longer commanded their respect.

The employment of spies on the part of gorernment had done as much to produce a change of opinion as the harsh exercise of authority. There might have been some eredit reflected on the government by their prerention of the projected mad march of the blanketeers on London, by their putting down the insurrection in Derbyshire, and by their suppression of the rising in Scotland, which resulterl in the capture of the rebels at Bonnymuir; but it was known that Oliver, a paid government agent, had counselled the blanket meeting and the Derbyshire outbreak, and in Lancashire it was well known that representations of the country being ripe for revolt, which oceasioned the rising in Scotland, were the work of spies; that although it was to have been simultaneous, not one, even of the most foolish and rash Lancashire men gare credence for a moment to the goverument agent ; and an incendiary placard, posted in Manchester on the 2nd of April, calling on the people to effect a revolution by force was laughed to scorn. Even the wicked conspiracy of 'Thistlewood and his confederates to assassinate the king's ministers at a cabinet dinner, had no effect in exciting sympathy in firour of the latter, for there was the strongest evidence to prove that Edwards, a gorernment spy, was the originator of the scheme, and that he had provided the arms with which the murders were to have been effected.

The personal character of the king, the combinatiou of cowardice and oppression in the conduct of his ministers, and especially the baseness of entrapping men into crimes which led them to the prison and the seaffold, had shaken the long established faith of the people in the constituted authorities. It seemed impossible that they could sink themselves further in public estimation-impossible that they could find a lower depth. But the profligacy, the cowardice, and the tyrauny, were again to be manifested; 
the object a defeneeless woman-the instruments, again, suborned and perjured spies! Manchester partook in the general feeling that the Queen was quite as much sinned against as sinning, and the proceedings against her did much to lessen amongst us that blind reverenee to royalty which had long eharacterised the town and neighbourhood.

The events deseribed, and the course to which public opinion seemed to be verging, induced reformers to think of some better means than they had previously possessed for the expression of their opinions. There had been many indications during the year 1820 of an increasing desire, among the middle elasses, for general and local reforms; and the convietion widened, that they might be more easily effected by ealm but spirited discussion than by riolent denunciations proceeding from great assemblages. The want of an efficient press began to be felt. I had often represented to the gentlemen with whom I associated the serviee that might be rendered to the cause of reform, by making Coudroy's Gazette a more efficient organ of our principles; and in conversations with my relative, David Prentice, of the Glasgow Chronicle, and with one or two proprietors of the Scotsman, I became convineed that not only would great publie good be effected by the establishment of an able journal, but that it would be remunerative as a business speculation. Others conversed on the matter with Mr. Fdward Baines, of Leeds, and Mr. Egerton Smith, of Liverpool, whose opinions were found to coincide with those $I$ had endeavoured to impress upon the minds of my friends. The sum of twelve hundred pounds was subseribed by, I believe, twelve individuals, and Mr. John Edward Tuylor was requested to take the undertaking upon himself, he, at that time, being the only person of our number whose time was not fully occupied by the management of extensive mereantile or manufacturing concerns, and having given, by his spirited defence when put on his trial for libel, by his appearances on the 
platform, and by his writings, evidence of the possession of abilities which were likely to render him highly useful as a public journalist and an oral advocate of liberal principles. My scheme had been to raise a paper upon the foundation laid by Cowdroy, and to continue him as the printer and publisher. A negociation was entered into between Mr. Taylor and Mr. Cowdroy, but it failed, and the former resolved to establish a new paper, if the subscribers to the fund would share with him in the risk.

It was agreed that the money should be lent on the condition that it should be repaid if the paper succeeded, so that its repayment could be made from profits, but that it should not be regarded as a debt if it were lost in making the experiment. There was generosity in this arrangement, the whole risk being encountered by the subscribers; except as regarded Mr. Taylor's personal services. And yet it was not more than fair that, the public benefit being the object, the possible loss should not bo borne by a single individual. The paper might probably be so far in advance of publie opinion as to be denied public support. The probability was, from Mr. Taylor's arowed radicalism, and his classification of Church of Englandism as a narketable commodity, that he would encounter bitter opposition from a very influential portion of the community. Under such circumstances, a mere ordinary loan, to be withdrawn at will, might have exposed the paper to extinguishment before the experiment, necessarily one requiring years for completion, could be fairly made. It was necessary for the success of a bold movement that it should be made freely-that the person making it should not have the fear of his own ruin before his eyes, in his attempt to lead public opinionwhich lagged far behind. It was a wise and just arrangement to ensure a fearless course in the attack of general and local misgovernment-the possibility of being behind public opinion, or of a too cautious waiting for its adrance. 
was never once thought of. There might occur occasions when a little gentle counsel to observe caution might be thought necessary-it never was supposed possible that the youthful and ardent reformer would need the spur. There was a road to fortune and to great public utility openedand there was no risk but that of loss of time to the individual-a young man, not then in any busiuess for which he was peculiarly fitted.

The prospectus of the newspaper was drawn, up with great caution. Some of the more ardent reformers thought that it should have defined more explicitly the kind of reforms that were to be advocated; but it was argued, on the other side, that as the personal friends of the editor all knew that he went the full length of the radicalism avowed by Sir Francis Burdett, it was better not to make a broad declaration of political opinions which would give offence amongst the classes having advertisements to bestow, but to wait for the opportunities which would be sure to arise of rindicating the principles of radical reform. Many opportunities presented themselves, but seldom thought the right ones, as subsequent events show. The following is a copy of the prospectus :-

"On Saturday the 5th of May, 1821, will be published,

Price Serenpenee,

No. 1 of a New Weekly Paper,

To be entitled

TIE MANCHESTER GUARDIAN.

"Printerl and published by J. Garnett, No. 28A, Market-street, SIanchester, where orders, advertisements, and communications will be thankfully received after the 30 th of $A$ pril ; and in the meantime, by Mr. Sowler, bookseller, St. Ann's Square, Messrs. Robinson and Ellis, St. Ann's l'lace, and Mr. John Ford, Market-street.

\section{" phospectes.}

"It may be safely asserted, that no former period, in the history of our country, has been marked by the agitation of questions of a more important character than those which are now claiming the attention of the public. To any one who regards, for a moment, the 
conflicting views and wishes of the commercial and agrieultural interests, - the consideration which may arise out of the existing laws for the regulation of our eurrency, the present and the anticipated pressure of the national debt and of taxation,- this statement will be sufficiently apparent.

"But there are other subjects, of greatcr and more permanent importance, which the circumstances of the times are forcing upon public attention. The effect of the great diffusion of education within the last quarter of a century, is attested by the greatly increased interest which political subjects excite, and the immense extension of the circle within whieh they are diseussed. It is of the utmost inportance that this increased interest should be turned to benefieial account; that it should be made effective in promoting all those amelionations in our laws and political institutions, of which experience has proved the necessit $y$, and in fixing upon a broader and more impregnable basis the fabric of our liberties.

"Though the eoncerns which relate to the internal prosperity of this country must always be of paramount consequence to its inhabitants, foreign politics will now be a subject of anxious observation; for there perhaps never was a period at which the affairs of other nations could awaken, in the minds of Englishmen, so deep an interest as at the present moment. The friends of freelom, everywhere, must watch, with intense anxiety, the progress of those efforts which sereral continental states, as well as others in the new world, are now making to free themselves from the incumbering pressure of antiquated and despotic gorernments, and to establish, in lieu thereof, institutions conformable to the increased intelligence of the age, and calculated for the promotion of public happiness and the security of popular rights. Proportionate to the interest with whieh these magnificent experiments are regarled, will be the wish that nothing may impede the suecess, or detract from the purity of their course; that no internal commotions, or external attacks, exeited or dictated by the unprineipled hostility of foreign and arbitrary govenuments, may defer the consolidation of such political establishments as are suited to the condition of the people, as the national will requires, and the national wants demand.

"The considerations whieh have just been stated seem to render the influence of the public press, the spirited discussion of political questions, and the accurate detail of facts, particularly important at this juncture; and we believe it will be generally admitted, that no existing local newspaper has possessed a degree of public consideration correspondent with the wealth and intelligence of this town and 
the surrounding district, and their high rank in the scalo of national importance. The present, therefore, seeins a farourable opportunity for establishing a newspaper which, by supporting a convistent character for sincere and underiating attachment to rational liberty, may promote that union and concentration amongst the friends of freedom in this neighbourhood whieh is in itself so desirable, and the want of which has been hitherto so sensibly felt.

"In conformity with these riews, arrangements are now making for the speedy publication of a paper under the title abore given. It will zealously enforce the prineiples of civil and religious liberty, in the most comprehensive sense of those terms; it will warmly adrocate the cause of reform; it will endearour to assist in the diffusion of just principles of political economy ; and support without reference to the party from which they emanate, whaterer measures may, aceording to the matured and unbiassed judgment of its conductors, tend to promote the moral adrantages or the political welfare of the community.

"The foreign intelligence of the week will be regularly and suecinetly detailed, whilst particular attention will be paid to parliamentary debates. The nost prominent speeches on each side of every important question will be given as fully as possible, and the remainder will be condensed with as much attention to the preserration of the spirit of the clebate as the limits of a reekly paper will permit.

"The commercinl connexions and the knowledge of the conductore of the Guardian will, they npprehend, give them the means of occasionally stating, with aceuracy and effect, the condition of trade and its prosperts, particularly as far as regards that inportant branch the cotton manufact ure. They hope thus, in some measure, to supply that information on this subject, the deficiency of which is often 10 obriously appanent, both amongst public men and those connected with the press.

"Whilst they will exereise the right of spirited and vigorous animadversion upon public questions, and boldly expose public delinquencies, they will selulously aroid all tendency to private slander, and endearour to prevent the best premogatires and most important duties of the press from degenerating into calumny and abuse.

"With a riew to make their journul as generally interesting a possible, ocensional notices of new books, and other subjects of a literary and seientific charaeter, will be introduced by the conductore of tho Guardian into its columns, which they will always feel a 
gratification in opening to the spirited and liberal communications of correspondents.

"Manchester is the centre of a most populous district, throughout which the Guardian will eireulate; and particular attention will be paid to all subjeets of loeal interest. Authentic articles of intelligence coming under this head, will, at all times, be thankfully receired. Details of interesting proceedings, whether of a commereial or political nature, in our courts of law, will from time to time be given; whilst every exertion will be made to present to its readers full and accurate reports of important public meetings, both in this and the neighbouring towns.

"The Manchester Guardian will commence its course with a rery considerable eireulation. It has seeured an extensive and valuable patronage throughout the surrounding distriets, amongst the classes to whom, more especially, advertisements are generally addressed; and whilst its conduetors respectfully solicit the support of advertisers both in this and the neighbouring towns, they confidently assure them that it will offer a most eligible medium for giving extensire publicity to their notices."

It will be seen that there is no promise of opinions upon the representative system that might not safely range between the annual parliaments, universal suffrage, and rote by ballot, of Major Cartwright, or the transfer of the East Retford seats to Manchester, the great instalment asked for by the editor's whig friend, Mr. G. W. Wood. There was ample verge and room enough for advocating the greatest or the smallest measure of reform, without incurring the charge of making any departure from the promises of the prospectus.

When the paper appeared, it was seen to be a very great improvement upon the then existing journals. With the Leeds Mercury and the Liverpool Mercury, the Gilasgow Chronicle and the Scotsman before him, Mr. Taylor had good models to follow. He was the first newspaper proprietor in Manchester who was capable of acting as editor, and he had engaged as reporter Mr. Jeremiah Garnett, a young man who had been an assistant in Mr. Wheeler's printing office, and was ocensionally employed in reporting. 
Regular " leaders," and substantively good, if not very full, local reports appeared weekly, and there was a businesslike look about the new paper which none of the others possessed. Never had a new journal better chances of success. The tory journalists looked with contempt upon their bold competitor, and, prognosticating his speedy extinction, made no attempt to improve upon their old jogtrot method of filling up their columns. "Leaders," with them, were a foolish innovation, and reports an unnecessary expense. Their way was the old way, and would continue to be the best way. New papers had been tried before and had not succeeded; the new-fangled thing would not last; there was no use in making any effort in competition with it; it would go down of itself. A eapital thing for the eirculation of the Guardian was this contempt. And then, as to advertisements; Mr. Wheeler, who had the main share, would receive none after one o'eloek on the Friday; he had what was then a large impression (about 3,000) of his paper to print, and he had to go to press at three o'clock; to bring advertisements at one o'clock on the day before publication was a thoughtless thing that needed reproof. The Guardian folks received those satisfactory accessions as late on Friday night as anybody ehoose to bring them-reeeiverl them with thanks; it was rather inconvenient to reeeive them at a later hour, but the inconvenience would be ineurred rather than disappoint the respectable parties who wished their announcements to appear next morning. All this was working into the hands of the innovator; he could not have eontrived better had he had the contrivance to himself. And yet the paper made slow, very slow progress. Mr. Cowdroy's circulation was littlo trenehed upon, for the people had respect for his prineiples, and did not like to leave an old public servant, and it was the eustom to send advertisements to Wheeler, and few had the courage to break through the custoin. This slow progress was discouraging; would there be any harm in 
endeavouring to conciliate, without any sacrifice of principle, a portion of the public who had something to bestow?

A short time before the establishment of the Guardian, it had been resolved to apply to parliament for an act to widen Market-street, then a narrow lane; at one place only wide enough barely to allow one cart to pass another, with a foot parement on each side only eighteen inches wide. The follawing gentlemen had been appointed on the 4th of April, 1821, to act as commissioners under the bill :-

\begin{tabular}{|c|c|c|}
\hline $\begin{array}{l}\text { axter, } \\
\text { shaw, } \\
\text { rley, } \\
\text { ett, } \\
\text { y, } \\
\text { egg, } \\
\text { peudall, } \\
\text { kson, } \\
\text { well, } \\
\text { ck, } \\
\text { lawson, } \\
\text { irwell, } \\
\text { atoff, } \\
\text { ielding, } \\
\text { ser, } \\
\text { eming, } \\
\text { andy, } \\
\text { arnett, } \\
\text { es, } \\
\text { le, } \\
\text { pyle, }\end{array}$ & $\begin{array}{l}\text { Benjamin Heywood, } \\
\text { Thomas IIarbottle, } \\
\text { David Holt, } \\
\text { Thomas Hardman, } \\
\text { James Hibbert, } \\
\text { John Harding, } \\
\text { Thomas C. Hewes, } \\
\text { John Kirkinan, } \\
\text { James Kennedy, } \\
\text { John Kenworthy, } \\
\text { Samuel Knight, } \\
\text { John Lomas, } \\
\text { Edward Loyd, } \\
\text { John Moore, } \\
\text { Francis Marris, } \\
\text { F. M. Mallalieu, } \\
\text { Robert Millington, } \\
\text { James M'Connel, } \\
\text { Henry Newbery, } \\
\text { Richard Potter, } \\
\text { Thomas Peel, } \\
\text { Shakespeare Phillips, } \\
\text { 'Thomus Potter, } \\
\text { Thomas Parker, }\end{array}$ & $\begin{array}{l}\text { John Railton, } \\
\text { James Ramsbottom, } \\
\text { Charles Rider, } \\
\text { William Roylance, } \\
\text { John Rateliffe, } \\
\text { Thomas Sharp, } \\
\text { J. B. Saunderson, } \\
\text { John Shuttleworth, } \\
\text { Richard Smith, } \\
\text { J. E. Taylor, } \\
\text { Peter Taylor, } \\
\text { Jas. Touehett, jun., } \\
\text { Joseph Todd, } \\
\text { William Tate, } \\
\text { G. W. Wood, } \\
\text { Thiomas Wilkins, } \\
\text { Joln Walker, } \\
\text { Riehard Warren, } \\
\text { Thos. Worthington, } \\
\text { W. W. Walmesley, } \\
\text { Gilbert Winter, } \\
\text { Thomas Watkins, } \\
\text { James Wood, } \\
\text { Peter Watson. }\end{array}$ \\
\hline
\end{tabular}

This was a formidable body of commissioners to carry into effect a single purpose; but $\mathbf{£ 2 0 0 , 0 0 0}$ had to be expended, and all parties were comprised in something like a fair proportion at the time. One fourth were whigs and 
reformers, one fourth had taken little part in politics, and one half were tories. Mr. Taylor, on coming from their meetings, used to say that some of them, whom he had not met across a table before, had expressed their surprise to find him a reasonable gentleman, and not a rough radical bear; and I used to say to him, "Beware, Taylor, lest, in your desire to eneiliate their good opinion, you permit them to rub the rough points off your radicalism;" and he would laugh and say there was no danger. This caution was not unnecessary; but, like many others, it failed in producing the effect intended.

"Beware of innovation; if you begin, you do not know where you will end," is the usual cry of the enemies of reform. Why should not one reform lead to another? This improvement of Market-street-Market-lnne, as it had been called-led to other improvements. A good street required good approaches, and they were made. A broad street showed advantageously in comparison with narrow ones, and the latter were widened. A handsome street was contrasted with a mean one, and the taste for beauty followed the provision for conrenience. There is no "finality" in such matters; why should there be in political elearings and eonstructions? A combination of the useful and the beautiful is sought in our streets and public buildings, and yet we are

- called to admire the narrow, the dark, the crooked, the mean and the unsavoury in our national institutions. 


\section{CHAPTER XIV.}

\section{A PERIOD OF CALM.}

A IIstory of the progress of political opinion, in any locality, would be defective without some notice, not merely of the establishment, but of the progress and workings of the newspaper press. Although, in the first instance, a newspaper may be established in consequence of the demand for the expression of particular opinions, and may be continued mainly to reflect the political feeling of a portion of the community, it begins to act upon the public mind, and, in its turn, assumes to dictate or insinuate the views of its conductors, and from being an organ becomes an instructor -for eril or for good, as the case may be. There is a reciprocal action. The public, or a portion of the public, acts upon and influences the newspaper; the newspaper acts upon and influences the public, or that portion of the public whose general opinions it represents. The desire to promote certain opinions leads to the establishment of a paper. It depends upon the prineiples or the temperament of its conductor whether he will, still adhering to the implied bond between his readers and himself, urge them onwards, or counsel circumspection and eaution,- whether he will, in the same army, be in front with the bold and the impetuous, or in the rear with the timid and the prudent. In either ease he will, to a certain extent, be influential. In either case he is still with his party; if at their head, he has the ardent; if in the rear, he las the cautious with him. As the organ of either division, he has the influence of his position, and he may use it to accelerate or retard its movement, without being liable to the charge of being a traitor to the general body, 
The ultimate polities of the Manchester Guardian were influenced greatly by the temperament of its conduetor. The ardour of youth overcame his vis inertia, and, for a time, he was an ardent leader; but, as years grew upon him, the disposition grew to esehew rash front-fighting. He had, besides, imbibed the leading principles of Malthus -and one does not often see a Malthusian a very ardent reformer: regarding the multitude as intruders upon nature's feast, after the places at the table have been all taken, he ean seareely forgive the impertinenee, and seldom gires his warm sympathies to the intruders. Mr. Taylor appeared as a journalist at the same time that Mr. Searlett (Cobbett's Lan'yer Scarlett) appeared as a poor-law reformer. Like MIr. Searlett, he wished to fix a maximum on the amount of poor's rate to be paid, no matter how much the amount of poverty to be relieved might increase; and, like him, he wished all persons who should be improvident enough to marry after that date to be excluded from all future relief. A meeting was called, to be held in the board-room of the Salford workhouse, on 24th May, 1821, to take Scarlett's bill into consideration; and as he had deelared that he would go and give it his support, I declared, in return, that, although I had never previously taken part in any public mecting, I should go and oppose him.

Nobody supported the prineiples of the bill but Mr. Tayler. He said he was rather disposed to approve of the principle of fixing a maximum on a liberal seale to the amount of rates, and that the clause which prohibited relief to persons who should marry after the passing of the act, unless in case of sickness, infirmity, or old age, had his desided approbation. With respect to the removal of the poor belonging to other parislies, he was in farour of a change in the mode of giving relief, rather than an entire abrogation of the law of settlement. Mr. Taylor went on to a point on which he and I were quite in agreement. He said that, great as was the evil arising from the poor-rates, 
there was another burthen, of scareely inferior importance, to which Mr. Scarlett had not thought proper to apply any limitation; he meant the county-rates. The inerease of these rates had been in a much greater proportion than that of the poor-rates; and, in all probability, a great part of that increase might be accounted for from the absence of a proper control over the expenditure. The treasurer was merely required by law to publish an account once a year. in one newspaper; and this mode of publication was as completely nugatory, with respect to the county at large, as a notice to the inhabitants of Manchester when affixed on the church door. He eertainly was not prepared to join in a petition against Mr. Searlett's bill, but if such a petition were roted by the meeting, he should move a elause praying for greater publicity and an efficient control with regard to the expenditure of the county-rates.

Although one or two in the meeting spoke in farour of the principles on which the existing poor-laws were founded, I felt that it was necessary that the meeting should be further informed before it came to a decision, and said that as a clause was inserted in the bill for the express purpose of permitting an inerease in the amount of county-rates, a petition regarding the bill ought to contain some reference to that part of it. In the year 1750 the amount was only $£ 40.000$, which had increased in 1815 to

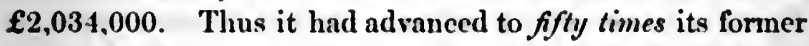
amount; whilst the sum expended on the poor, the increase of which furnished the argument for the supporters of the bill, had only increased ninefold, an increase which was searcely equivalent to the increase of population, of taxes, and the price of the necessaries of life oceasioned by a deprecinted eurrency. The bill seemed to be intended entirely to abolish the poor-lnws, which were right in principle. The clause for restraining marriage was particularly objectionable, because if relief was not afforded by the parish those who were refused relief would become 
vagrants. The preamble of the bill was false, insomuch as it recognised the assumptiou that provision for the poor increased the number of paupers, which was contradicted by the fact that in 1750 the amount of rates did exceed, and indeed was rather less than their amount in 1688 . If the law itself had had the lenst tendency to increase the number of the poor, that tendency would have shown itself as soon as a legal provision was made for their support; but as no increase had taken place, up to 1750 , the period from which Mr. Scarlett's statements commeneed, it was a legitimnte conclusion that in periods of prosperity the poorrates would not inerease, and that the reeent augmentation was fairly to be attributed to taxation, the evils of war, and the fluetuations of commerce. To attempt to fix a maximum was highly presumptuous. Could a maximum be fixed to the amount of taxation, or a limit to human misery and wretehedness? It was unjust to deprive the labourer of that legislative provision to which he was entitled, whilst be was exposed to the operation of laws injurious to his interests - to the corn-law, for instance, which, whilst it raised the price of the poor man's breal, lessened the demand for the produce of his labour. With regard to the improvident habits said to be fostered by an unlinited provision, it might be replied that the wretchedly poor were the most improvident; that in Ireland, where there were no poorlaus, early marriages were more frequent than they were in England: and that industrious habits were more likely to be preserved when the distressed labourer was reliered at the parish table, and he would return more eheerfully to his work when he obtained it there than after having been compelled to go farther and leg for charity.

The resolutions passed were strongly condemnatory of the bill as cruel and unjust; similar resolutions were passed in Manchester, and a general feeling against it being manifested throughout the country the bill was defeated. It may be supposed that there could not be a long continuance 
of agreement of opinion between myself and one who would have destroyed the future legal provision for the poor, whilst the corn-law remained unrepealed, whilst emigration was prohibited, whilst a turn-out for wages was punished as a breach of the law, whilst for the mass of the people there was not eren the shadow of representation, and whilst the taxation required to defray the expenses of a long war was erushing the people to the earth. "Are you going to give a report of this meeting ?" I asked. "No," was the reply; "I think it has not been of so mueh importanee." I said, "Ihen, if you think it is of no importance to you, you will surely have no objection to my asking Cowdroy to report it :"' The report appeared in the Guardian, but on the following week appeared a laboured defenee of the elauses which the meeting had condemned, purporting to be in reply, not to me, but to William Cobbett.

The kind of loyalty, which transferred the reverence which should be paid to the kingly office to the indiridual who oceupied the throne, had been greatly lessened by the persecution of the queen by George the Fourth; but eoronations had always been occasions for display, and disliked as the prinee regent had been, the inhabitants of Manehester were not disposed to innovate upon the ancient custom. A splendid proeession was got up, which was simultaneously in passage along Piccadilly, Bank Top, Downing-street, Ardwiek Green, Higher Ardwiek, Chancery-lane, Ancoats Bridge. Great Ancoats-street, and Swanstreet, a length of two miles and a half. But the pageant was not what it had been in the olden time. There was much more of a staid and sober loyalty than had been seen before. At sereral places in the line of progress, particularly in Salford, Bank Top, and in Great Ancoats, the Manchester Yeomanry, who had been thanked by the prinee regent for their share in dispersing, at the point of the sword, a legally convened and peaceably held meeting, 
were assailed with groans and hissings; and there was not, on the whole route, any manifestation of enthusinsm. In many of the trades also there was a strong disinclination to join in the festivities of the day, from an idea that to assist in the cclebration of a ceremony from which the queen was excluded, would seem to imply an approbation on their part of the eruel proceedings against her. The people enjoyed the spectacle and the holiday, but, so far as the procession was coneerned, there was an absence of all those exlibitions of exuberant loyalty which used to be manifested on public occasions during the reign of the decencies-observing George III. There needed something more than the parade of a procession, to excite a livelier demonstration. Loyal feeling required a stimulant to rouse it from its languor-and it was supplied by some who renembered the glorious and uproarious doings of more charch-and-king times. The Guardian thus describes the secnes which were exhibited in the evening :-

"Here we should have been glad to close our aecount of the proceedings of the day, but we have a further duty to dischargeunplensant and, perlaps, invidious. About five o'clock commenced the distribution of meat and beer to the populace. The stations for this were-the New Market, Sluudehill; the Slinmbles, at Bank Top; those nt the top of Bridge-street; in Cunpl Field Market; the Ceorge and Dragon, Irdwiek; the Clirendon public-house, Chorlton Row; in Hulme, in Strangeways, in Motram's Field, and in Oldfield Rond. At many, we fenr we mny say most of these places, scenes were exhibited which cren the pencil of a Hogarth would fail to pourtray. At the New Market, Shudehill, the ment and loaves were thrown out high from the doos and windows of the warehouses where they had been stored; the populace sernubling for them as they could. It resenbled the throwing of gools out of the windows of a warehouse on fire rather than augthing else we can compare it to. There was shameful waste and general confusion. At an early hour the stage ereveyl for the applicants to stand upon gave way, and one person was kille!l, nnd acternl daugeronsly wounded by the fall. When the liejuor was distributing, we saw whole pitchers thrown indiscriminately among the cruwd-anen holding up their hats to receive drink; people 
quarrelling and fighting for the possession of a jug ; the strong taking liquor from the weak; boys and girls, men and women, in a condition of beastly drunkenness, staggering before the depository of ale, or lying prostrate on the ground, under erery rariety of circumstance, and in every degree of exposure, swearing, gronning, romiting, but calling for more liquor when they could not stand, or even sit, to drink it. Every kind of excess, indeed, which tho most fertile imagination can conceive, or the most graphie pen describe, was there witnessed in nauseous and loathsome extraragance. Nerer did we see, and we hope to God nerer again shall we see, human nature so degraded. The scenes of whieh we have now attempted a faint description, were exhibited, though, perhaps, to scarcely the same extent, at Camp Field, in Sulford, and at the Shambles in Bridgestreet; and we trust the experience of this day will hare given to the committee who managed the proceedings a lesson whieh they will never forget. As to the distribution of meat and liquor, there are two or three lives lost, and fourteen patients in the infirmary, sereral of them dangerously injured; from the erents of the day. It must be understood, howerer, that we consider the bulk of our labouring population not implicated in these disgraceful scenes. The wretched actors in them were that rabble, without conduct or fixed principles, which is always to be found amongst the population of an immenso town. We do not so much wonder at these brutal excesses, as lament that men of edueation, of eharacter, and of talent, should have furnished the temptation to them."

These beastly excesses excited so much disgust as greatly to forward the cause of temperance. Henry Hunt, in his desire to cripple an oppressive and tyrannical government, had prepared the way by inculeating an abstinence from the use of exciseable commodities, and a number of radicals had become water-drinkers. The authorities of Manchester, alarmed at the progress of such abstinence, had issued, at the public expense, innumerable printed papers, recommending the free use of the "old English beverage," good brown ale, and had denouneed all who adrocated the abandonment of that "checring and strengthening" drink as enemies to the corporeal constitution of Finglishmen. Hunt's advice to abstain was greatly strengthened by the shameless adriec from the "constituted authorities" to drink. Work- 
ing men, in their self-respect, began to say that they would not make beasts of themselves to please boroughreeve, or constable, or parson. There needed but a disgraceful exhibition, like that which has been described, to suggest the propriety of some association amongst working men to discontinue practices which degraded them. From this time, irrespective of political motives, commeneed little social meetings, at which the jug of water on the table supplied the place of beer and gin;- and these little parties were the precursors of that general temperance movement which has so greatly improved the aspeet of society amongst the humbler classes, who are now about as outwardly decorous as the gentlemen were when I first visited Manchester, in 1811, when it was no unusual thing to see three or four "respectable" manufacturers staggering down Marketstreet-lane, in the broad daylight of a summer afternoon, trolling out their drunken catches.

The political cconomy of Manchester was better than its politics. It had long enjoyed a singular immunity from the distress occasioncd by the failure of banks. In 1819, a committee of the House of Lords had reported that, from the year 1790 to 1818 , no fewer than 273 commissioners of bankruptey had been issued against country bankers, generally issuing their own notes. More than half of these failures had taken place in five years of general eommereial distress-in 1793, 1810, 1814,1815, and 1816. In 1814 twenty banks had failed, in 1815 twenty-six, in 1816 thirtyseren. From these failures and their very disastrous consequences Lancashire was almost entirely free, whilst Yorkshire had suffered largely. In Lancashire there were only from three to six banks which issued local notes, whilst in Yorkshire there were sixty-seven. In Yorkshire the issue of local notes had given the bankers great temptation to discount largely and imprudently, and that county was deluged with their notes, greatly to the encourngement of rash speculation. In periods of adversity the sudden dimi- 
nution of discounts produced great and wide-spread distress, aggravated by the failure of banks, against which there had been a "run." From these mischievous alternations Lancashire was almost free. It had to encounter periods of great commereial depression, but they had not been aggravated by excessive issues and sudden contractions of a local eurreney. Its exemption from these sudden changes might be traced to an event which had oceurred long previous to the time of which we are writing-the failure of Liresey and Co., of Manchester, a failure, probably, more disastrous and overwhelming than Lancashire had erer before encountered, or, considering the relative amount of commereial and manufacturing transaetions, has ever suffered sinee. The experienee derived from that event had created a universal dislike to local notes, and the general opinion had operated upon the bankers of the district, and repressed the issue of those "rags" which Cobbett so often declaimed against.

The Bank Restriction Aet of 1798 had permitted an extraordinary issue of Bank of England notes, which had consequently become greatly depreeiated in ralue. With the restoration of peace was to have come the restoration of a cash eurrency. Mr. Wade, in his British History, says that this was effected before the passing of Mr. Peel's bill in 1819, but the great depression of prices, deeply felt in Manehester during the latter half of that year, and the first half of 1820 - a depression by which the comparatively small business in wbich I was a partner suffered to the amount of $£ 3,000$-showed that the previous preparation for the resumption of cash payments had only half done its work. Mr. Peel's bill had fixed May, 1823, as the period of resumption, but the bank, by an accumulation of gold, was enabled to anticipate the fixed time, and recommended specie payments in May, 1821. Mr. Hopkins, in his Great Britain during the last Forty Fears, says, "It was considered that the peace rendered it necessary that preparations should 
be made for the returning, at no distant period, to the old metallic standard of ralue, and for repealing the Bank Restriction Act. This not only induced the Bank of England to begin to reduce the quantity of their notes in circulation, and to increase their stock of gold, but it also compelled country bankers to limit their issues, as they also would be more liable to be called upon to pay in gold. Such considerations, no doubt, indueed a more cautious issue of notes; and the quantity of currency was kept down nearly to what it would have been if the exports had been suffered to draw gold from the commercial world to furnish a metallic currency for 'Great Britain." Mr. Hopkins, like Mr. Wade, attributes alterations of the value of the currency, after May, 1821, to other causes than Pcel's Bill; but the diminution of bank issues went on till 1822, greatly to the depression of prices.

The total amounts of Bank of England and country bank notes in circulation were:-

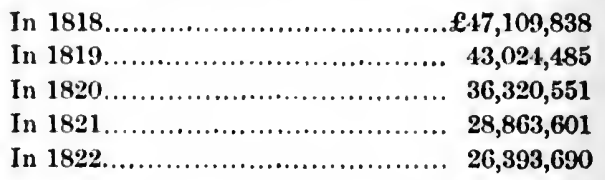

A gradual diminution of the paper currency to the

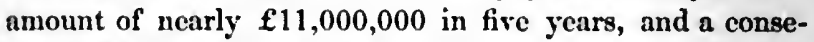
quent fall in the prices of commodities, occasioned the cry, like that which still continues to arise from Birmingham, for more paper. The country was suffering the consequence of its former intoxication, and, in its exhaustion, wanted a repetition of the stimulating dram. There were symptoms of preparation in Manchester for the issue of small local notes. But Livesey's failure, and the failure of country banks in 1814, 1815, and 1816, were not forgotten, and the first business establishments in the town and neighbourhood were determined to nip the contemplated innovation in the bud. $\Lambda$ requisition was made to the boroughrecres 
and constables of Manchester and Salford, to eall a public meeting on 23rd August, 1821, " to consider of the measures necessary for securing a satisfactory eurrency for these towns and neighbourhood, in consequence of the cessation of the issues of small notes by the Bank of England." The following are some of the signatures:-

\begin{tabular}{|c|c|}
\hline $\begin{array}{l}\text { Hibbert, Wanklyn, \& Bradshaw, } \\
\text { John Greenwood, } \\
\text { W. Birch, } \\
\text { Robert Duck, } \\
\text { F. Phillips and Sons, } \\
\text { Thomas Peel and Brothers, } \\
\text { H. J. and R. Barton, } \\
\text { Philips, Wood, and Co. } \\
\text { John Allen and Co. } \\
\text { Leighs and Darwell, } \\
\text { Ceorge Neden, } \\
\text { James and John Holford, } \\
\text { Dickson, Watson, and Co. } \\
\text { Broadhurst, Marris, and Co. } \\
\text { Edward Barter and Co. } \\
\text { James Cooke, } \\
\text { Benjamin Sandford, } \\
\text { Peter Ewart and Co. } \\
\text { C. F. Brandt and Co. } \\
\text { T. Kirkham and Sons, } \\
\text { W. Hardman and Sons, } \\
\text { Otho Hulme and Sons, } \\
\text { Jackson, Bushforth, and Scott, } \\
\text { John and William Ileygate, }\end{array}$ & $\begin{array}{l}\text { Thomas Houldsworth, } \\
\text { Thomas Potter, } \\
\text { T. J. and J. Ashton, } \\
\text { James Beardoe, } \\
\text { James Burt, } \\
\text { Buchan and Shaw, } \\
\text { T. and. M. Harbottle, } \\
\text { Hole and Potter, } \\
\text { James and William Barrett, } \\
\text { Thomas Hilton, } \\
\text { Thomas Wilkinson, } \\
\text { Stephen Sheldon, } \\
\text { Holywell Twist Company, } \\
\text { Robert and William Garnett } \\
\text { John Shuttleworth, } \\
\text { Markland Brothers, } \\
\text { W. Grant and Brothers, } \\
\text { Thomas and Richard Potter, } \\
\text { Fielden Brothers, } \\
\text { John Edward Taylor, } \\
\text { Benjamin Binyon, } \\
\text { Blackwall and Sons, } \\
\text { James Kennedy, } \\
\text { Gardner and Harter, }\end{array}$ \\
\hline
\end{tabular}
Edenborough, Chittenden, \& Co. Harrey, Tysoe, and Co.

Amongst the requisitionists were persons of every shade of political opinion, tories, whigs, radicals, and Cobbettites. At the public meeting, Mr. George William Wood, afterwards member, for a short time, for Lancashire, and subsequently for Kendal, partner in the great house of Philips and Co., took the lead. The following may be taken as a summary of his arguments :-

1st. Local notes were not a legal tender; no person was 
obliged to receive them in payment of a debt; and an angry creditor, or a vindictive laudlord, might inearcerate a debtor, although payment was offered in the only eirculating medium in the neighbourhood.

2nd. A great variety of local notes might be put in circulation, issued by firms of different degrees of stability, whilst amongst the labouring classes, amongst whom such notes would ehiefly circulate, they would not be able to discern the good from the bad, and would be compelled to take all indiscriminately.

3rd. Local notes were not adapted for distant payments. The notes which were issued at York would not pass at Newcastle, and the currency of Neweastle would be of no ase at Edinburgh; and thus the traveller would be compelled, at every remove, to exchange the notes in his possession for those of the district which he was about to enter.

4th. A serious evil would be the risk of loss on local notes. In periods of great commereial distress and alarm, it frequently happened that the stability of a bank began to be suspected - a run ensued, and it fell ; and it not unfrequently occurred that the banks of the distriet became involved in one common ruin.

5th. A serious objection to the issue of local notes was the facility which they afforded to improvident trading. An advance of his own notes cost the banker nothing, and the speculator procured them with a facility which tempted him to trade far beyond his capital, to the great detriment of firms whose business was conducted on the solid basis of property and capital.

Mr. Sothern, an agent on the Bridgewater Trust, then under the management of Mr. Bradshaw, who, from the great extent of his power and the manner in which he exercised it was commonly ealled Duke Bradshaw, informed the mecting that if the publie were to sanction the continuance of issues of local notes, Mr. Bradshaw, who paid 
$\mathbf{£} 300,000$ a year in wages, would issue his own notes, and in all probability would soon have a million in circulation. Mr. Thomas Sharp, afterwards of the firm of Sharp, Roberts, and Co., contended stoutly that all inconvenience from the issue of local notes would be obviated by requiring them to be payable in London, and stated that he had the authority of Messrs. Jones and Co., and Messrs. Heywood and Co., who were willing to make their notes thu payable; but the meeting, unwilling to allow any modification of a system which had a tendency to create a false appearance of prosperity at one time and an undue depression at another, refused to listen to the proposal. Mr. John Edward Taylor said that no one could doubt the perfect security of all dealings with the highly respectable banks named; but others might arise who could not be so safely trusted; the meeting had already heard that one gentleman, whose paper would probably be accepted as readily as those of our own bankers, intended to issue an enormous amount of notes for wages; and if they might credit the expressed determination of other houses, the town would soon be deluged with local paper, and exposed to the danger of great loss. Mr. Sharp had proposed an amendment, but it was negatived, and the original resolutions were passed by a great majority. They contained a series of aryuments similar to those noticed as forming a summary of Mr. G. W. Wood's speech; but the practical result was the issuing for signature of the following declaration :-

"Manchester, August 23, 1821.

"We, the undersigned, being deeply impressed with the inconrenience and danger to be apprehended from the circulation of local notes in this great commercial town, do hereby declare it to be our intention not to receive sny such notes in payment after the 31st instant, except in cases of extreme necessity; in all which cases we pleclge ourselres not to circulate such notes."

The declaration was very numerously signed, and so well observed, that, in the great panic at the elose of 1825 , 
which brought so many country banks to the ground, Manchester was comparatively unscathed. The advertised declaration, with the names attached, filled the six columns of the first page of the Munchester Guardian, a very pretty addition to the advertisements of the new paper, which had only twenty-seren others, filling four columns, about its usual number and measure.

The defeat of Sidmouth's bill, ten years previous to this period, had not extinguished the spirit of intolerance. The reader of the present day will peruse, with curious interest, the proceedings adopted against a respectable gentleman for the crime of preaching the gospel in the open air, and will be reminded of the persecution which was encountered some half century before, by John Wesley and his colleagues, when they presumed to think that God might be worshipped, and his revelations made known, under the canopy of the hearens, as well as in temples made by the hands of men.

At the Salford sessions, July the 23rd, 1821, Mr. Samuel Waller, a respectable cotton spinner, of Ashton-underLyne, a lay preacher amongst the primitive methodists, was indieted for having, in the king's highway, in that town, unlawfully and injudiciously caused and procured a great number of persons to assemble together, obstructing the said highway, to the great damage and common nuisance of the liege subjects of our lord the king; and with making a noise, riot, tumult, and disturbance; and with making such riot by shouting and singing, and wholly choking up and obstructing the street and highway.

Mr. Starkie, who was employed for the prosecution, forgetting the scrmon on the mount, began his address to the jury by declaring that if any one would produce him a text from scripture to support the practice of openair preaching, he would cousent to an acquittal ! He hoped that the verdiet of the jury would be such as to convince the defendant that neither he nor any other person, not 
even a minister of the church of England, if it were allowable to eonceive that a elergyman should ever so far forget his duty, had a right to obstruct the highway, ranting and roaring, to the common nuisance of his majesty's subjects, on pretenee that he was doing his duty. He did not mean to deny the defendant's right to preach; he had a right to preach, in proper places, and there let him rant and roar as he pleased. Mr. Starkie then told the jury that a bear had once been removed because his growling disturbed the neighbours; and he coneluded his address by saying, that if the defendant, like the bear, was determined to rant and roar, he must do it in proper places.

There was not any proof of obstruction. The deputy constable said the people were singing merry tunes. Another man said they sung like ballad singers down the street. When a hearse was approaching, making some noise, Mr. Waller preached a little louder, and witness "thowt it rather hawkward." A horse or carriage might, he thought, go through.

Mr. Courtney made an eloquent defence, denying any obstruction and any nuisanec, and asking the jury, as Christians, to give their verdiet in favour of one who had only done what had been done by the Saviour.

The Reverend W. R. Hay, the chairman of the quarter sessions, who had commanded the military attack on a peaceable and defenecless multitude on the 16th of August, 1819 , and had been rewarded by being presented to the rich living of Rochdale, told the jury they had only to ask themselves whether the assembling of 200 or 300 persons in publie day, in the publie streets, was or was not a nuisance. Christianity, he said, had nothing to do with the question.

The jury having found that Mr. Waller had obstrueted the street, the reverend chairman inquired whether, after the verdiet had been given, as he took it for granted that the prosecution was not instituted with a view to a rin- 
dietire punishment, any compromise could take place, by the defendant entering into sureties not again to offend in like manner? Mr. Waller was not disposed to promise that he should not again preach in the open air, and declined to apply for any mitigation of sentence.

The Reverend Mr. Hay then addressing the defendant, told him that the sentence about to be pronouneed was not intended to be rindictive, but to show him that individual opinion was not to be set up against the law. He was then senteneed to three months' imprisonment, and to give security, himself in $£ 50$, and two sureties in $£ 25$ each, to keep the peace and be of good behaviour for two years from the period of his liberation!

On Tuesday, October 19th, Mr. Waller, haring endured his three months' imprisonment, appeared before Mr. Norris, the stipendiary magistrate, to enter into recognizanees to keep the peace, the sureties being Mr. John Potter and Mr. Thomas Harbottle. When the recognizanee was read,

Mr. Waller begged the indulgenee of the eourt for a moment. Ile understood that the effect of the recognizance into which he had just entered, was nothing more than to bind him to keep the peace, which he might conscientiously say he had never broken.

Mr. Norris.-That is a question into which I cannot enter. You are now bound to keep the peace, and you must keep it.

Mr. Waller.-I merely meant to say, that as I cannot conscientiously refrain from preaching the gospel-

Mr. Norris. - You must keep the peace, or your recognizance, and those of the gentlemen who are bound with you, will be forfeited.

Mr. Waller.-It is my intention and wish to keep the pence; but 1 beg to know whether my preaching the gospel, not in the street, will be considered as a breach of the peace:

Mr. Norris. - I shall not ansucer any questions put to me 
on the subject. You appear to have a correct view of the nature of the recognizance into which you have entered, and I can give you no information on the subject.

Mr. Norris then direeted Mr. Waller to be taken down to prison, but his solicitor, Mr. George Hadfield, said that he had already been imprisoned three months. The jailer said that months were always taken, at the sessions, to mean calendar months, and the justice taking the jailor's interpretation of the law, Mr. Waller was taken to prison for six days more. It is a maxim of law, that " there is no wrong without a remedy ;" but this, like many others, is only to be met with in books. In proof of this it may be stated, that an application was made on behalf of Mr. Waller to the Court of King's Bench, for a mandamus, commanding the clerk of the peace to enter on the record the sentence as pronounced, which was for " three months," whereas it appeared it was entered three calendar months, which increased the punishment. Howerer, the court said it had no authority to order the court of quarter sessions to draw up their record in a particular form and manner, and therefore it refused to interfere. So that if the clerk of these justices had inserted twelve instead of three months, Mr. Waller, it would seem had no remedy. Such was the temper of the times and the determination of what are called courts of justice. Mr. Waller was of a seet, some of whose members might write the word "precher," instead of "preacher," and to persons guilty of such atrocity, the liberty taken by the apostles of Christ was not to be permitted in a country where Christianity is "part and parcel of the law of the land."

Before we take leave of the period of Hunt-radicalism, it may satisfy a not impertinent curiosity to look at the comparative progress of the old organ of the reformers, Coucdroy's Manchester Gazette, and the new paper which had assumed to itself the task of directing public opinion, the Manchester Guardian. The following gives a list of 
the advertisements in eaeh, commeneing from the first number of the Guardian :-

\begin{tabular}{|c|c|c|}
\hline May 5 & $\begin{array}{l}\text { GEARDAS. GAZETTE. } \\
\ldots \ldots 47 \ldots \ldots \ldots 34\end{array}$ & $\begin{array}{l}\text { Guardas. Gazette. } \\
\text { Aug. } 4 \ldots \ldots . \ldots 27 \ldots \ldots .22\end{array}$ \\
\hline$" 12$ & $\ldots \ldots 42 \ldots \ldots \ldots 33$ & $" 11 \ldots \ldots \ldots . . . .19 \ldots \ldots .22$ \\
\hline$" 19$ & $\ldots \ldots .34 \ldots \ldots \ldots 23$ & $\ldots \ldots . . .29$ \\
\hline$\Rightarrow 26$ & $\ldots \ldots .30 \ldots \ldots .27$ &, $25 \ldots \ldots \ldots \ldots 41 \ldots \ldots \ldots 31$ \\
\hline June 2 & $\ldots \ldots 2 \pi \ldots$ & Sept. 1 ......... 29 ...... \\
\hline$\Rightarrow 9$ & $\ldots \ldots 39 \ldots \ldots \ldots 32$ &, $8 \ldots \ldots \ldots \ldots 29$ \\
\hline, 16 & ...... 29 ........ 35 & $" 15 \ldots \ldots \ldots . .29 \ldots \ldots . . \ldots 28$ \\
\hline . ", 23 & $\ldots \ldots .39 \ldots \ldots . .31$ &, $22 \ldots \ldots \ldots . . .29 \ldots \ldots$ \\
\hline , 30 & $\ldots \ldots 37 \ldots \ldots . .38$ & 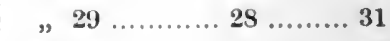 \\
\hline Juḷ 7 & $\ldots \ldots .43 \ldots \ldots \ldots 39$ & Oet. $\quad 6 \ldots \ldots \ldots \ldots, 31 \ldots \ldots . . .32$ \\
\hline , 14 & $\ldots \ldots 3+\ldots \ldots .27$ &, $13 \ldots \ldots \ldots .41 \ldots \ldots . . .28$ \\
\hline, 21 & $\ldots \ldots .35 \ldots \ldots .21$ & $" 20 \ldots \ldots \ldots .35 \ldots \ldots .34$ \\
\hline .28 & $\ldots \ldots 27 \ldots \ldots \ldots 28$ & $" 27 \ldots \ldots \ldots . . .36 \ldots \ldots 29$ \\
\hline
\end{tabular}

This was but a diseouraging eommencement of the new journal. To have beaten by only five advertisements a week a paper printed on old and hattered type, and unable to defray the expense of an editorial and reporting staff, showed, on the one hand, that there was a reluctance to desert an old and faithful servant of the publie, under whatever disadvantage he continued his labours; but, on the other hand, the fact that the two liberal papers could not muster more than sixty-two advertisements between them, while the tory papers had three times the number, argued that the advocacy of wide reforms did not find much farour with the "advertising public." Here was seen the wisdom of the arrangement that Mr. "Taylor should not be ealled upon to repay, cxcept from renlised profits, the $\mathfrak{f l , 2 0 0}$ raised to estublish the Ciunrlian; for perseveranee, at his owu risk, in the secmingly hopeless task of establishing a new paper, under such eireunstances, would have been an evidenee of pullic spirit which the projectors could not have hasl a right to expect of any one. It may easily be inagined, however, that many misgivings must have 
assailed the conductor, and that many times he must have deeply pondered how, of course without any sacrifice of prineiple, he could escape the odium which still attached itself, in the estimation of the influential, to an unmitigated expression of that sort of radicalism which had been " rulgarised" by its association with the names of Hunt and his more humble, hard-handed, and not rery smooth-tongued colleagues.

In the preceding part of this chapter a list is given of fifty names of individuals and firms which were subseribed to a requisition for calling a meeting in opposition to local notes, and it will be perused with a melancholy interest, seeing how many of the persons have died sinee, and how many of the firms have been broken up by death or commercial misfortunes. I had the curiosity, two years ago, to ascertain how many of the members of the Literary and Philosophical Society survive after a period of twentyseren years. In the list of members, in the society's memoirs, made out in March, 1848, the following are the only persons who were eleeted previous to the end of 1821 :

Samuel Kay, November 1, 1799.

John Kennedy, April 29, 1803.

James Ainsworth, January 25, 1805.

Peter Clare, F.R.A.S., A pril 27, 1810.

Laurence Buchan, Norember 2, 1810.

Gilbert Winter, Norember 2, 1810.

Rev. John Gooch Robberls, April 26, 1811.

Robert Stuart, January 21, 1814.

Sir Beujamin Heywood, Bart, F.R.S., January 27, 1815.

George Murray, January 27, 1815.

John Joore, F.L.S., January 27, 1815.

Robert Thorpe, November 3, 1815.

John Daries, M.W.S., Norember 1, 1816.

Robert IIyde Greg, F.G.S., January 24, 1817.

Joseph Cheeseborough Dyer, April 24, 1818.

Alexander Kay, Oetober 30, 1818.

Riehard Flint, Oetober 30, 1818.

Archibald Prentice, January 22, 1819. 
Eaton Hodgkinson, F.R.S., M.R.I.A., F.G.S., \&c., Jan. 21, 1820.

Rev. John James Tayler, B.A., January 26, 1821.

John Blackwall, January 26, 1821.

Thomas 'Turner, F.R.C.S., A pril 19, 1821.

Joseph Jordan, October 19, 1821.

Richard Parr Bamber, October 19, 1821.

There were one hundred and sixty-nine members of the society in March, 1848, of whom one hundred and forty-five had been clected since 1821 . 'Thus does one race disappear and another take its place. The attention of the society was directed more to physical than to moral or political science, and hence it escaped the risk which other associations, taking a wider and bolder range of subjects, cncountered in 1794 and 1817. Its existence, from 1781, throughout a period peculiarly unfirourable for intellectual pursuits, had, no doubt, a beneficial influence on a portion of Manchester society, humanizing and refining, while, out of its circle, there was so much of mind-degrading intolerance. It may easily be imagined how much such men as Robert Hyde Greg, Joseph C. Dyer, and Alexander Kay would enjoy its scéances, when political bigotry grierously embittered other associations. In this point of view the memory of the Henrys, the Percivals, and the Daltons, will be regarded with veneration, even without reference to their services in the adrancement of science. 


\section{CHAPTER XV.}

\section{A SHORT PERIOD OF PLENTY.}

HIstory is generally a record of crime and suffering. The sword and the spear furnish more stirring descriptions than the ploughshare and the pruning-hook. The doings of a Bonaparte filled the post horns of all Europe; the writings of a Bentham are read by only a very few philosophical philanthropists. The man who storms and fires a eity is immortalised by the historian's pen; he who enables a nation to carn its food by honest labour dies unnoticed, and to posterity, unknown. How briefly are periods of pcace passed over in our oldest and most authentic record! After the deliveranee of Israel from a foreign yoke, effected under the direetion of Deborah, the prophetess, we read :"And the land had rest forty years." We read that Tolak "judged Israel twenty and three years," and that Jair "judged Israel twenty and two years." We hear no more of them; they judged rightly; the people vere at rest; no history of misdoings was needed. The history of eightyfive ycars of tranquillity, of peace, and, as we may presume, of plenty, is told in three lines. Would that the history of mankind were capable of such brief but precious record ! In our little narrow history-ground of Manchester we find, now and then, some such refreshing resting-places, some such green dew-bespangled ficlds in the thirsty waste. In thirty years of war and seareity, hunger and nakedness, to three-fourths of the community, are three or four years of peace and plenty, nothing to the afflicted millions? In so long a period of constantly deepening gloom, was a brie gleam of general suushine nothing? History was silent, but the people were fed. And they thought also,-those 
briefly well-fed multitudes-calmly, but not less deeply, and their inquiry was:- "Why should it not always be thus ?" Mr. Wheeler, in his history of Manchester, makes a great leap from Hunt's trial at York, in 1820, to the bank failures at the end of 1825 , and the loom-breakings and factory-burnings of 1826 . There lay a happy period some time between. One could then draw the curtains, and wheel round the sofa nearer to the cheerful fire, and the more enjoy the social meal, from the conviction that there was comfort also in the cottage, and no wailings in the street. It was worth soluething, on the Saturday night, to see the working man's wife need her husband's help to carry home the heary basket, filled with bread and beef, and flour and suet. But then came the reflection that the corn-law was unrepealed, and that a single bad harvest might mar all this comfort.

Inch outery came from the landowners at the cheapness of provisions. The Saturday's basket of the operative was well filled, but the landlord's rents were not well paid. What cared the latter about the well-filled baskets, when their coffers wanted the supply which hitherto had been wrung out from the people by war prices? The loyalists of 1793 were not more horror-struck at the murder of Maria Antoinette than the soil-owners of 1822 were at the fall of wheat to forty shillings a quarter. They had expected that their law of 1815 would keep up the price to eighty shillings ; and a profuse issue of paper money, accompanying scanty harvests, had kept up prices. In 1816, 1817 , and 1818 , defieient harvests occurred-that of the former being calculated as below the average to a greater extent than in any year since the period at the close of the previous eentury, and prices rose in consequence, so as to exeed the ragte at which foreign com might be admitted, and 2,600,000 quarters of wheat were imported in 1817 . and 1818. The harvest of 1820 was supposed to be onefourth beyond the average; that of 1821 was large, but of 
inferior quality; and that of 1822 was again beyond the arerage, and was unusually early. In the week ending the 24th of December, 1822, the avernge prices were-wheat, 38s. 8 d. ; barley, 29s. 4d.; oats, 18s. 9d. ; rye, 23s. 6d. ; beans, 28s. 10d. ; peas, 28s. 4 d. ; being 418. 4d., 10s. 8d., 8s. 3d., 29s. 6d., 24s. 2d., 23s. 8d., lower than the scale which had been fixed upon, ostensibly for the protection of the farmer, but really for the protection of the landowner. The farmers did indeed now suffer, for during peace, and with a currency much enhanced in value, they were called upon to pay the rents which they had paid when they had war prices and a greatly depreciated currency. Many were the proposals made to relieve this " agricultural distress," and parliament resolved to alleviate the pressure upon the "distressed landowners," and that $£ 1,000,000$ should be adranced to them, in exchequer bills, when the average price of wheat was under sixty shillings. Great efforts were made to make the country beliere that the agricultural labourers were in a most wretched condition in consequence of the low prices of corn; but it began then to be understood that the wages of farm labour never roso in proportion to the rise in the price of farm produce, and that, although they had fallen in 1822 , the recipients wero more than eompensated by the low price of food.

Mr. Searlett, Cobbett's Lawyer Scarlett, availed himself of the cry of agricultural distress to introduce a bill so to amend the poor-laws as to prevent removals. He calculated on the support of the landowners, who, after having been released of the burden of supporting a portion of their poor, who had migrated to tho manufacturing districts, might be supposed very willing to have a guarantee against their return to their native parishes. In justice to the landlords generally, and to the tories of Manchester, it should be mentioned that they withheld their sanetion from this scheme. It was manifestly unjust that the landlords, after taxing the manuficturing distriets by the monopoly in the 
supply of corn, should lay another tax upon them to relieve the poor who were born on their estates, and had been driven out, by insufficient wages, to seek employment in the manufacturing towns. When, twenty-four years after, the corn-laws were prospeetively repealed, it was no more than just that labourers should find relief where they had given labour. Lawyer Scarlett had, besides, gone bcyond the principle of his last-session Malthusian bill. He now made the effort to empower magistrates to commit to prison any person applying for relief, against whom any former "misconduct" could be proved. I had been foreed by convietion, in spite of a very strong disinelination to take part in public meetings, to attend, in the previous year, one held in Snlford, and to give my opposition to his then bill; and I felt it was my duty to attend one held in the collegiate church, in Manchester; on the 23rd of May, 1822, that I might protest against powers being granted to magistrates which might be used greatly to the oppression of the poor. I found that the opposition at this mecting was confined to the proposal that there should be no future removals. I told the meeting that a question of a legal provision for the poor had now become better understood than it had been lately; that it was acknowledged, generally, that poor laws were absolutely necessary in the existing state of the country; that Mr. Scarlett, howerer, notwithstanding his signal defeat last session, had introduced into his new bill a clause tending directly to overturn a law which, more than any other, had kept alive the moral and physical energies of the people. I then alluded to the clause empowering magistrates to imprison all such persons applying for relief as they (the justices) might deem to have been idle, extraragant, or to have misconducted themselves, and asked who could tell what was idleness or extravagance? Some persons thought the people were idle if they did not work more than twelve hours a day, and some that they 
were extraragant if they ate any animal food. Was it. right that persons so thinking should have the power to send a man to prison for what they might choose to call idleness or extravagance? But the bill also went to empower magistrates to commit for previous misconduct. Could any lawyer present say what misconduct meant? "If it were left to the discretion of a magistrate to decide," I said, " he might commit any man to prison. He might commit him to jail because, like me, he was a reformer, or a dissenter, or because he had attended a public meeting." My resolution was not opposed, but it underwent much verbal criticism : it was, however, ultimately passed unanimously in the following terms, amended by Mr. J. Garnett:"That the power intended to be vested in justices of the peace to commit to the House of Correction individuals applying for relief on account of alleged idleness, extraragance, or misconduct, is not only vaguc and undefined in its terms, but also at variance with the spirit of the English laws." Looking back, at this distance of time, upon the proceedings of that meeting, and knowing that an expression of public opinion from loyal Manchester was not uninfluential in the legislature, I may be permitted to express my satisfaction that I did something to keep that opinion right on a question so deeply affecting the interests and liberties of the poorer elasses; for many of my friends amongst the whigs, and some amongst the reformers, at that time, were more smitten with the Malthusian doetrines than my opponents, the tories; and it required some courage in me, not accustomed to take part in publie meetings, to stand forward and defend the old beneficent law of Elizabeth, in opposition to the new lights of economical science. From this time I began to be strongly importuned to do something towards revivifying Coudroy's Gazette; but I still retained faith in the polities of the Guardian, although I differed with it in political economy.

Ireland, the mass of its people considered, received little beuefit by the abundance of corn food. Irishmen did not 
eat wheaten bread, although they raised wheat. Their barley was consumed in the manuficture of whiskey, and even their oats were exported. Their only food was potatoes, and when they liad no potatoes they had nothing. Owing to the heary rains of the previous year, the potato erop of the south of Ireland had almost entirely failed, and the price of this staple food of the population was quadrupled. Before the end of April, 1822, the provinee of Munster was in a state of actual starvation. The people erowded into the towns in the vain hope of finding employment and food, and their sufferings were aggrarated by the wide-spread typhus fever. General sympathy was excited in England, and a committee was formed in London, and corresponding committees in various parts of the kingdom, to originate subseriptions for the relief of Irish sufferers. Mauchester was not behind other places in the benevolent effort. A public meeting was held on May 16th, and a large committee was appointed to solieit subseriptions. The following were some of the larger contributions;-

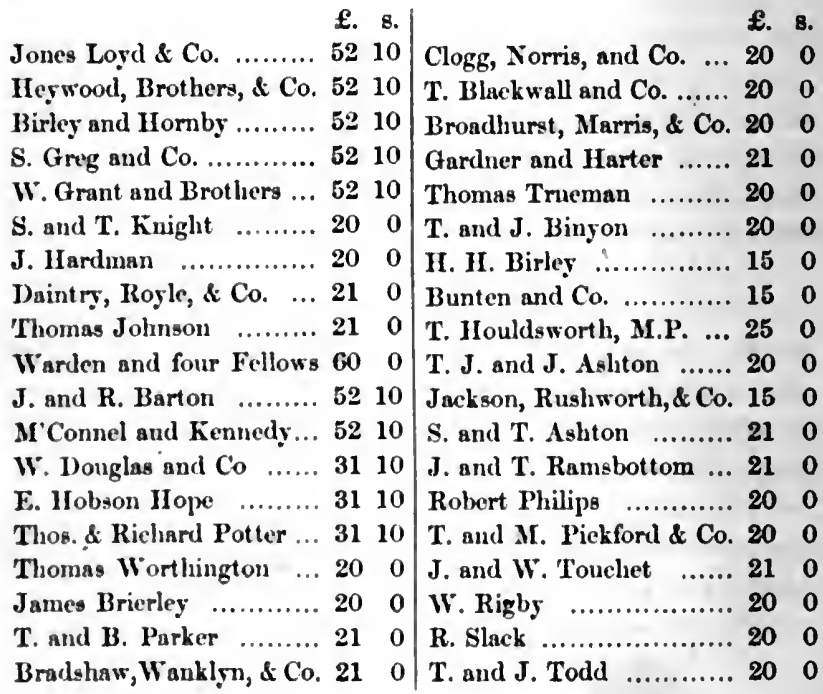


These are smaller sums than such houses now contribute in cases of emergency ; but very active exertions were made to obtain subscriptions from all ranks of the community, and the amount raised in Manchester exceeded $\mathbf{f} 4500$. Let wie again say of the men who were the opponents of reform, that their praetical benerolence was strongly manifested on this pressing occasion.

The "Bridge-strect Gang" were at this time in actire operation. In April, 1821, they preferred bills, at the Middlesex sessions, against Wardell, editor of the Statesman, Thelwal, editor of the Champion, Dolby, publisher of the Political Dictionary, and Mary Ann Carlile, for seditious libels. They had assumed the name of the Constitutional Association, and the functions of the law officers of the crown, and were supported by the contributions of the excessirely loyal throughout the kingdom, including many in Manchester. In the autumn of 1821 , a poor man, named Ridgeway, a bookseller in this town, was conricted of selling a libellous publication to a man named Mellor, a spy, or "informer," employed by the "gang," and their sole witness. The evidenee of this fellow having been shaken by the testimony of Ridgeway and some of his neighbours, and a motion having been made for a new trial, the "gang" considered it necessary to strengthen his testimony, and a few eounter affidarits having been procured, the question became one of conflicting evidence. The King's Bench decided against Ridgeway's application. Murray, the attorney of the "gang," determined to put Ridgeway effeetually down, attended at the Lancaster spring assizes, 1822, and presented an indietment of perjury against him, which, upon the evidence of Mellor and others, was found. Poor Ridgeway was then in prison, his wife and four ehildren were dependent upon eharity for their subsistence, and he had not a shilling to defend himself. But he found friends amongst the reformers of Manchester-Richard Potter's " small but firm band." His case was investigated, evidenee 
was examined, and it was found that there were about a score of witnesses, of unimpeachable eharacter, ready to testify to the truth of his statement. These witnesses were sent to Lancaster on Saturday, the 24th of August, and were in waiting there until the following Wednesday, when the case was called-and put off, on an affidavit from $\mathbf{M r}$. Murray, the "gang's" solicitor, that a material witness eould not be able to attend until next day. Next day came, the witness was present, and the trial was about to begin, when the elerk of the crown informed his lordship that there was a certiorari to remove the case into the King's Bench !

Mr. Baran Wood.-Then of course I cannot proceed with it.

Mr. Sergeant Hullock. -That is the object, my lord; we are not quite ready.

Mr. Brougham.- Your lordship will see the hardship of this proceeding is, that the poor defendant will be compelled to bring his twenty witnesses again, at an expense which he cannot afford.

Mr. Baron Wood.-I cannot help that, Mr. Brougham; I have no power. It may be a defeet in the law.

Mr. Brougham.-Yes, my lord, and there are always persons (looking at Mr. Murray) ready to avail themselves of defects in the larr, for the purpose of oppressing an indiridual. Then, my lond, there is another hardship on the poor defendant. He is now in confinement in this jail for a misdemeanour, and I suppose there will be an attompt to keep him in prison after the expiration of his term of imprison. ment, until the next assizes. If your lordship could make an order that he should be almitted to bail at Manehester, where he could have no difficulty in procuring bail-

Mr. Baron Wood.-I hare no power to do that, Mr. Brougham.

And so the business terminated. Fortunately for Ridgeway, the material witness" himself was in prison before his testimony was needed; and so the prosecution failed. The " gang" gainel nothing by it but a great addition to the odium they had previously ineurred.

In November of this year the members of the ycomanry corps presented Mr. Hugh Birley, their commander, with a sword, as a testimony of their respect. The Guardian, in 
commenting on the presentation, said: "Whether, however. we are to be classed with the "designing or the deceived,' 'the ignorant or the ill-disposed,' we have no hesitation in arowing our firm and unchangeable opinion, that the strongest censures which have been applied to the magistrates and yeomanry, for their conduct on the 16th of August, are not stronger than they deserve; and that the sanction of all the speeial juries, and of all the judges in the kingdom, would be quite insufficient to wash out the 'damned spot' of blood with which that event has tainted them." Yet, notwithstanding this declaration of unchangeable opinion, notwithstanding the stain of this "damned spot," ten years had not elapsed ere the editor of the Guardian went, hand-in-hand and arm-in-arm, with Mr. H. H. Birley, in the attempt to impose a member of Mr. Birley's choice upon newly enfranchised Manchester! Let no man talk of an unchangeable opinion whose opinion is founded on present expediency.

A trial in 1823, arising out of the strong feeling which prevailed against the issue of local bank notes, on the part, as subsequent disastrous failures proved, of persons whose "promise to pay" was valueless, excited a considerable amount of interest in Lancashire. An attorney in Manchester, John Dicas - $\varepsilon$ name which afterwards became noted or notorious in consequence of numerous actions for libel against the London press-had been eommitted for two years to Lancaster Castle, for conspiring with a bankrupt to defraud his creditors. This had somewhat dnmaged his character in Manchester, and he had subsequently to leave the town to aroid a distraint for poor-rates. This man, thus banishing himself, was not exactly the sort of person to commence the business of a banker and to issuc notes, but he had formed a connection with a Mr. Williams, in Holywell, Flintshire, and in 1821 they commenced banking, and the manufacture of local paper which had some eurrency in Wales. Some of their notes having found their 
way to Manchester, notwithstanding the resolution of its merchants, manufacturers, and shopkecpers to discourage the circulation of such "rags," the Guardian, in a long article against the pouring of the paper "rubbish into the once pure stream of Manchester eirculation," gave expression to the following "broad hints":-

"To such an extent do the people of Manchester actually go in this folly - in this malness-that we ourselves saw, a few days since, notes payable at a place in Wales, which had been issued by two ragabonds, one of whom was formerly a pettifogger in this town, who, after two years' imprisonment for conspiring with a bankrupt to defraud his creditors-after being consequently shunned by all decent men-after making from his last residence here a moonlight flit to aroid a distraint for poor rates, which he had appealed against on the ground of porerty-went immediately, in conjunction with the other wreteh, to eommence banking, and is now beginning to arenge himself for the treatment he experienced here, by indirectly drawing away our solid valuables, in exehange for his dirty rags, which prescent no security but his or his partner's integrity and scealth."

Somcthing clse was said about a prisun bird and confessed pauper. A notice of action was served against the Guarlian, and much speculation took place as to the result. Few found fault with the exposure, but there was no doubt that a libel had been published. No names were mentioned; no name of a town; no name eren of a county was given. Would Dicas prove that the libel applied to him by proving that he was the only Manchester attorncy who had been two years imprisoned for frand? He did so. On the trial at Shrewsbury, a former clerk of Diens proved that Dicas had been couvicted of conspiracy, in issuing a fraudulent commission of bankruptey against a person of the name of Bulwer; - he knew it because he was in court when the case was tried. This was evidence that the allusion was to Dicas, and it followed that the application of the term " wretch" was to Mr. Dicas's partner. To prove special damages, a clerk in the bank was examined, who said that 
about $\mathbf{f 1 , 9 0 0}$ in one-pound notes had been in cireulation, and that, in consequenee of what had been said in the Guavdian, notes were sent in to the bank for payment to the amount of $£ 1,000$ in six weeks, and that no sooner were they re-issued than they were sent in again. This was indeed a dreadful ren - a run which, in six weeks, brought baek the large amount of $f 1,000$. The damages were laid at $£ 5,000$; the rerdiet of the jury was for $£ 10$. Probably, had not the partner, who had not run away, and had not been imprisoned, been called a wretch, the verdiet would have been for a furthing. The eosts, amounting to several hundred pounds, fell on the Guardian; but the greater part of the money was repaid by a subscription, and the paper had the advantage, from that time, of being considered as the guardian of the eommereial interests of the town and neighbourhood-a reputation much more valuable, in a pecuniary point of view, than the fame of being the adrocate of popular rights.

Very considerable interest was excited by another trial this year by an attempt to murder an extensive manufacturer at Preston. On the morning of Sunday, July 27 th, as Mr. Horroeks was returning from church, and was opening the gate of his partuer, Mr. Miller, a man named Ryding came behind and gave him a blow with a heavy kitchen eleaver, which eut through the hat and inflicted a frightful wound on the head. Mr. Ilorroeks turned round in time to avert a seeond blow aimed at the head, and to receive it and sucessive blows on the arm, which received several severe euts. Mr. IIorroeks' eries of murder brought assistanee, and the man was taken into custody, without making any effort to eseape. There had been a period of tranquillity, and comparative prosperity to the working classes. This attempt at assassination in broad daylight, espeeially when it became known, from the prisoner's own deelaration, that he had been the writer of an anonymous letter, threatening Mr. Horrocks with death, unless he 
raised the wages of his spinners, gave great alarm, for it was beliered to be the result of a conspiracy amongst the operatives to effect their objects by the murder of masters who resisted their demands. Such an atrocity gare the more alarm, oceurring at a time when the working elasses were enjoying more than usual comforts. There were many circumstanees, howerer, which had soured the temper of the operatives, and rendered them hostile to their employers. Their efforts to obtain reform in parliament had exposed them to the ycoman's sword and the eonstable's staff. Many had their wages paid in "truck," instead of the current coin of the realm. The combination laws rendered them liable to imprisonment if they jointly attempted, no matter how peaceable the means, to raise wages, or to resist reduction of wages. 'There was a law, also, to prevent their emigration to other countries, where there was a better demand for their labour; and there was a law to impose heavy duties on food imported for their consumption. 'Their masters generally were opposed to reform, and firm supporters of the combination laws. Many of them profited largely by the truck system; most were opposed to emigration, in the fear that they would lose their best hands; and few amongst them had the courage or inclination to protest against the imporerishing bread tax. It was not surprising that they were regarded as the enemies of the working classes-not surprising that an oceasional unavoidable reduction of wages should be attributed to their grasping cupidity. Ryding, a young man of twenty-two years of age, had been afflicted with a disease in the brain, which made him excedingly desponding at times, and at other brief times almost delirious, but did not seem otherwise to affect his intellect. Hearing continually of the oppression exercised by the masters, this lad determined to arenge tho wrongs of his class. IIe considered Horrocks and Miller to be the principal movers in a reduction of wages. It oeeurred to him, one night in bed, that it was his duty to 
shoot them. He awoke several times in the night, and the same idea always presented itself. It beeame his daydream, and he became unfit for his work, and was always discharged afterwards from erery situation he obtained. Fate seemed to be impelling him onwards. It was necessary, he thought, that the nation should know what oppressors the masters at Preston were. The conriction, under the combination laws, of some operative spinners in that town, gave a further stimulus to action. He would not kill-his mind scems to have ultimately rerolted against that-but he would inflict grievous wounds, that he himself might be tried for life, and that by his trial and death he might rouse the country to a redress of the wrongs under which he and his class were suffering! The jury returned a verdict of not guilty, on the ground of insanity, and the victim of strangely perverted heroism was lost sight of in the recesses of a prison, in which he was to be shut up during his majesty's pleasure.

In the brief periods of comparative commercial prosperity, amidst the innumerable wild schemes of speculation which start up, there has been usually, in Manchester, the origination of some publiely useful institution, which stands as a mark that all was not madness at the period. On the 1st of October, 1823, a meeting was held at the Exchange, Dr. Davenport IIulme in the chair, to consider the propriety of establishing an institution for the promotion of literature, science, and the fine arts. The principal speaker was Mr. George William Wood, but the following gentlemen took a part in the proceedings by moving and seconding the twenty-two resolutions :-

1. George William Wood-Robert Hindley.

2. Thomas Hardman-Robert Clristie.

3. Thomas Ainsworth $\rightarrow$ Jonathan Dawson.

4. David Holt-J. A. Raneome.

5. William Garnett-Thomas Sharp.

6. G. W. Wood-G. T. Bury.

7. R. H. Greg-Joseph Birley. 
8. William Townend-Darid Holt.

9. Samuel Kay-Charles Brandt.

10. Thomas Hoyle-Samuel Kay.

11. Charles Brandt-Beresford Turner.

12. Robert Philips-S. Barton.

13. Henry Hardie, M.D.-Dr. Lyon.

14. James Beardoe-George Hole.

15. J. A. Ransome-John Macfarlane.

16. E. J. Loyd-Joseph Birley.

17. Thomas Ainsworth-E. J. Loyd.

18. Thomas Sharp-Darid Ilolt.

19. James H. Heron-S. Barton.

20. G. W. Wood-Thomas Ainsworth.

21. David IIolt-Thomas Ainsworth.

22. Charles Greenway-Thomas Sharp.

The subscriptions amounted, before the end of the year, to upwards of $£ 14,000$, and being continued into the prosperous year 1824, the Royal Institution was founded, which, though not so extensively useful as it might have been, and may still be, under more energetic and more popular government, is highly creditable to the period when it was established. 


\section{CHAPTER XVI.}

PURCUASE OF " COWDROY'S GAZETTE."

Is a preceding chapter some account was given of the establishment of the Guardian. In describing the development of public opinion in this metropolis of the northern provinees, it seemed necessary to notice the origin of a journal which became the organ of whiggism, from its resurrection, after the horrors of the French Revolution had been forgotten, until its decadence, when the people began to believe that they had about as much interest in the quarrels between the whig and tory factions as in those between the rival houses of Montagu and Capulet. There was a great leap to be taken to bring toryism up to a rational radicalism. Whiggery was a conrenient middle stepping-stone, broad enough for men to stand upon, and sncer at the tardy fools behind, and the too-fast fools before. The Guardian, after a two years' experienec of the difficulty of progression, took up its position half-way, rather disposed to wait for the coming up of those who were in the rear, than to mareh forward and join those who were in advance. Throughout the whole of its third year it would have been difficult for any one reading its columns to discover the hand of a reformer. And yet it would have been difficult to point out any departure from the promises set forth in its prospectus, so vaguely had they been expressed. Had any one said: "Here are no reform principles," the reply would have been : "Look here-here are two lines expressing a doubt. that the House of Conimons fully represents the people. You say there is no fruit in the orehard. Look here. Don't you see a pear at the top of that branch, behind 
those leares?" The paper had not abandoned its prineiples-it had only ceased to give them earnest expression.

Considerable dissatisfaction was expressed by some of the gentlemen who had been most instrumental in establishing the journal, expecting that it would be a bold and uncompromising exponent of political truth and progress; and I was often advised to purchase Coudroy's Gazette, and offered assistance if $I$ found that it required more capital than I could command. The eircumstances of the times, as well as my own desire to contribute something to the formation of a right public opinion, induced me to think firourably of the proposition. On the foundation of a healthy state of trade, a superstructure of false confidence had been raised. The spirit of rash speculation prevailed, and I plainly perceived that a panie would follow. I foresaw that the house, from the sale of whose goods I derived two-thirds of my income, would not be able to stand, should there come, as I wns eertain there would come, a sudden depression of trade, with failures, great reduction of prices, and an extraordinary limitation of discounts. If it was imprudent to enter into a new business, it was imprulent to wait in one upon which a fearful crash was sure to come. I made the purchase of copyright and materials; paid $£ 800$ down, and engaged to pay Mrs. Cowdroy $£ 100$ a year for eight years; laid out $£ 300$ more on a new press and a new fount of type; and thus I commeneed a new earecr, full of health and hope. Mrs. Cowdroy had derived a living from the paper, though a scanty one. The wholo wages of compositors and pressmen amounted to only seren pounds a weck. I should have to increase the expenditure; but an increase of the circulation, which was 1,000 a week, to 1.500 , and of the advertisements in the same proportion, wonld, I expected, meet the extra outlay.

I had full faith that the principles I held would, ultimately, be those held by the great majority of the people inhabiting Manchester and its populous neighbourhood. 
There needed to be, in my firm belief, only carnest and frequent appeals to common sense, common humanity, and common justice, to effect great and beneficial changes. I could not suppose that masters would long ask for liberty to combine, while workmen were liable to imprisonment for a peaceful agreement among themselves, as to what wages they would accept; that a mereantile and manufacturing community would long quictly submit to a law which limited their trade, and laid a gricrous tax upon the people's food; that there would be a continual insult to Dissenters, by their cxclusion from corporate offices; that Roman Catholics would be long bitterly insulted and decply wronged, by being excluded from all share in the representation of the country; that the inhabitants of Manchester would long submit to the dictation of a petty officer of the Lord of the Manor; that Manchester and Salford, with 200,000 inhabitants, would long remain unrepresented, while one hundred boroughs, whose united population amounted only to that number, continued to send two hundred members to parlianent; or that, in demanding freedom ourselves, we could deny it to the hundreds of thousands who were enduring the galling yoke of slavery in our colonies. I had full faith that these changes might be effected, and some belief that I might aid in effecting them. Goëthe has said: "Our wishes are presentiments of the capabilities which lic within us, are harbingers of that we shall be able to perform. Whatever we are able and would like to do presents itself to our imagination, as without us and in the future; we feel a longing after that which we already possess in secret. Thus a passionate anticipating grasp changes the truly possible into a dreamed reality." In commencing $m y$ career as a journalist, I KNEW that the principles I adrocated would ultimately be triumphant-KNEW it as certainly as if the chart of futurity lay open before me. It might not be in my time as a journalist-not in my time as a man-but " come it would 
for all that ;" and that conviction sustained me throughout all subsequent diffieulties-diffieulties which would have driven many a man mad. I felt that the existence of a thoroughly independent paper for only a few years would create a demand for its continuance; I might fail-I might dic-the prineiples, onee fairly enunciated, could neither fail nor dic. Much that I anticipated has been done; I had some share, howerer humble, in the doing; and the paper, renovated in June, 1824, and earried on for a quarter of a century, as the Manchester Gazette, the Manchester Times and Gazette, and the Manchester Examiner and Times, is now not only at the head of the Manchester press, but at the head of the provincial press of the United Kingdom. I knew that the exponent and organ of progression would reach this rank; I always said it would-siid so when I was laughed at for the saying. The tine? It is not for man to fix a time; he must work to accelerate the peidod-nust have fuith that "the braw time is coming." All my rejoicing at things done was not reserved till they were done. I knew that they would be done, and rejoiced while they were adoing. Mueh is yet to do-much there will always be to do, for the cultivated ficld will go back to barrenness if it be left alone; but as the work is wanted men will be found to do it. Rough pionecrs have gone before and cleared away many of the most formidable obstructions. Cultivation must follow the elearing of the forest and jungle.

About the beginning of 1824, three gentlemen, Mr. William Firbairn, Mr. Thomas Ilopkins, and Mr. Richard Roberts, conversing on the proposal to establish an institution (now the Royal Institution) for the promotion of literature and the fine arts, thought it wonld be well that another should be established to teach the application of seience to mechanical and manufacturing art, for the benefit of young men who needed practical instruetion and had not the means to obtain it, unless offered to them at a 
cheap rate. They each agreed to contribute ten pounds, and to endeavour to induee others to follow their example. A public meeting was held on the 17th of April, at the Bridgewater Arms, in High-street, Benjamin Heywood, Esq., in the chair, in which it was resolved that an institution, to be ealled the Manchester Mechanies' Institution, should be formed, the leading objects of which should be the delivery of lectures on the various seienees and their application to the arts, and the establishment of a suitable library for reference and circulation. Mr. Heywood subseribed twenty guineas, and the following gentlemen ten guincas cach :-

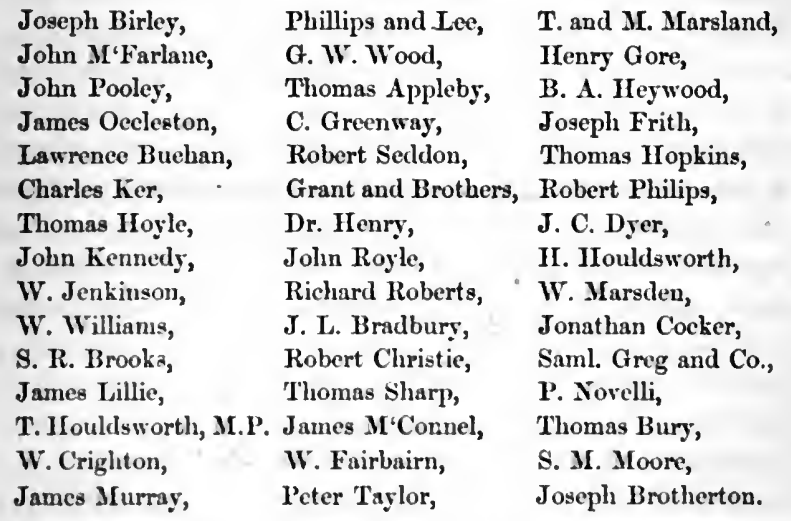

Such was the commencement of an institution which, after being subject to many vieissitudes, has become one of the most popular and most useful of its elass, combining the diffusion of very valuable and solid information with the promotion of rational and refining recreation, at the cheapest possible rate.

The establishment of the Mechanics' Institution, subscriptions to the amount of $\mathbf{1 2 6 , 0 0 0}$ towards erecting the Royal Institution, and of $\mathfrak{f 5 , 0 0 0}$ towards the enlargement of the Infirmary, together with a generous contribution 
for the relief of sufferers by great inundations in Germany, were some of the results of the prosperous year 1824 . Manchester had not yet participated much in the rash spirit of speculation which was exhibited in London. It had mainly manifested itself here in the purchase of the raw material in the staple article of manufincture; but the speculations in cotton were kept considerably in check by a series of able articles in the Guardian, written by a gentleman of great experience in that trade, who exposed the various devices made use of to raise prices. At the close of the year, howerer, some symptoms were exhibited here of the tendency to enter upon great joint-stock speculations. The first impulse to the share mania in London seems to have been given by the intention of ministers to recognise the independence of the South American States having transpired. The avidity for shares in the mines may be shown by comparing the prices in five of the prineipal companies at two periods, only a month apart:-

\begin{tabular}{|c|c|c|}
\hline Dec. 10 & 1824 & Jan. 11, 1 \\
\hline $\mathfrak{x}$ & s. & $\mathcal{E}$ \\
\hline Anglo-Mexienn & 0 pren & 158 \\
\hline Brazilian ................... 0 & 10 dis.. & 66 \\
\hline Columbia ................. 19 & 0 pren & 82 \\
\hline Reul del Monte ...........550 & & $\ldots \ldots, \ldots \ldots 1,350$ \\
\hline United Mexican ........... 35 & 0 & $\ldots \ldots \ldots \ldots 1,550$ \\
\hline
\end{tabular}

It was computed that in the end of 1824 , and the begin. ning of 1825,276 companies had been projected, with a proposed enpital of $f 174,000,000$ ! Of these 33 were for canals and docks, 48 for railroads, 42 for gas, 34 for metal mines, 20 for insurances, 23 for banking, 12 for navigation and packets. $\Lambda$ man, in haste to become rich, had no more to do than put down his name for shares, pay a few pounds for his scrip, sell at a high premium, and repent the process. As John Knox said, when he saw the splendour of Queen Mary's court at Holyrood, "Ah, ladies, it is a brave world this-if it would but last." We shall 
hear by and by of the bubble bursting; and, all the teachings of expericnce being thrown away, of fresh bubbles being blown, to burst in their turn.

At the opening of the parliamentary session, February 2nd, 1826, the contentment and the thriving condition of all classes of the people was the most remarkable topic in the royal speech. There were some symptoms, howerer, that the prosperity was not to be of very long duration. In the general confidenee money was so easily obtained, that speculation was carried to a considerable height, and fears began to be entertained by those who had been accustomed to mark the causes of commereial fluctuation, that a considerable depression would follow. The abundant harvest of 1822 had, for some time, counteracted the mischievous operation of the corn law, but adrancing prices convinced all who had given any thought to the subject, that there was great danger to be apprehended whenever the crops should yield less than a good average. In 1825 a movement was made in Manchester, not for the repeal, but for the revision of the law. In its increased vigour it had existed ten years, and consequently had become "venerable." It had been an "innovation" ten years bcfore; it had now become an "establishment;" to abolish it would have been a "revolution." The movement had no energy in it-carried no hearty sympathies with it. Mr. William Garnett, afterwards an unsuceessful candidate for the representation of Salford, was the prineipal speaker. It was a sensible speech enough for a merchant, on a mere question of exehanges. There was no allusion to the semistarvation of millions when a seanty harvest came; agriculture would flourish when trade flourished; prohibitory duties provoked retaliatory duties on the part of other nations; America night beeome a formidable manufacturing rival; therefore it was desirable that the law should be revised. It was a sensible speech enough, but without life or soul-dry as a remainder biscuit after a long voyage. 
One resolution, mored by Mr. John Edward Taylor, scconded by Mr. Frederick Lilly, a corn merchant, was as follows :-

"That permaneutly high prices of corn would be evidently and generally injurious : they would either greatly depreciate the condition of our manufacturing popnlation, or, by raising the scages of labowr, materially increase the facilities for successful rivalship with our productive industry abroad; and the declining condition of our trade, which would then eusue, would eventually entail on the agrieulturists, in common with every other class of the community, the greatest suffering."

There was here a repetition of the fallacy on which the elder Sir Robert Peel and the other manufacturers of Manchester, had opposed the bill of 1815- a fallacy which, being thus sinctioned by Manchester, was repeated by the landlord class throughont all the subsequent struggle for free trade; and their constant taunt to the manufacturing elass was, that they were afraid of high prices of food, only because they were afraid that they would pay a higher rate of wages. The meeting was, however, memorable, inasmuch as it was the first held by merehants and manufacturers, after the working elasses had been driven out of the ficld of agitation for free trade and free representation. It was a small movement in the right direction, and our gratitude to the movers is not to be withheld, because they elung to one or two old fallacies. The fault was with the mereantile and manufacturing publie generally, who believed that the then prosperity was to be lasting.

The Catlorlie $A$ ssociation, under the energetic Ieadership of Daniel $O$ Connell, had made itself formidable to the ministry, nnd it had become obvious that, ere long, there would be a majority of the members of the House of Commons in favour of the removal of Catholic disabilities. Emancipation encountered a bigoted and intolerant opposition ; the cry of "No popery!" resounded throughout the land, and many men believed that the days of tho 
bloody Mary would be revired if a few Romanists obtained admission into the legislature. Be it noted, horrever, that there were not a few reformers, and not a few sincere friends of religious liberty, who had some diffculty in giving in their adhesion to the cause, seeing the terms on which some of the leading Catholics were willing to purchase eligibility to seats in cither house of parliament. These leaders were willing to buy their own enfranchisement by the sacrifice of the electoral rights of the forty-shilling freeholders in Ireland; and, to give an assuranee that they would be peaceable subjects, they were ready to submit to the degradation of having their priests made paid pensioners of the state. In a letter to the Catholic Association, read at one of its meetings, in Mareh (the last which was held, in consequenee of an aet for its dissolution), Mr. O'Connell said :-

- "Although a provision for our elcrgy is spoken of, it ecrtainly has not been spoken of in any shape which could excite the least alarm in the mind of the most scrupulous Catholic; and, as to the prineiple of that measure, is there any one who imagines that the Catholic people of Ireland can be finally admitted into the condition of subjects, so as to constitute a portion of the universal British nation, without our clergy having a natural and just clain on the state for a provision? If there be, I am not of their opinion. I own I think that our elergy ought to receive a support from that state which we, the Catholics, contribute to maintain with our moneys and our blood; and as to the details of that prorision, are they not safe in the hands of our excellent prelates, subject also as they must be to the inspection of all the people, Protestant aud Catholic of the empire, before they can be finally adopted or made into a law ?"

Mr. O'Conuell afterwards changed his opinions with regard to the endowment of the Catholie priests. Beforo his death he declared his strong opposition to the endowment of any religious seet; and he denouneed every proposal to endow the priests of his own faith, as an attempt to make them the miserable slaves of the state. But he would have permitted them to accept the insidious 
bribe in 1825 . Then it was "safe in the hands of excellent prelates." While, therefore, we notice, with indignation, the intolerance and bigotry which would have excluded men from seats in parliament on account of their conseicntious religious opinions, let it be recollected that there were not a few undoubted friends of religious liberty, who were not willing that emaneipation should be had, accompanied by an ngreed-to condition which was as much at variance with principle as was the exelusion of the Catholies from the legislature. The pnyment of the Catholic priests was to have been one "wing" of the Catholic Emancipation Bill-the disfranchisement of the forty-shilling frecholders was to hare been another, Mr. O'Connell, in the letter which we hare already quoted, said, in reference to this proposed wholesale disfranchisement :-

"Iet me ask, will not the stimulus to make freeholders exist after emancipation as powerfully as at present? It certainly will; and, if it do exist, is it robbing the poor to make a law which shall compel any landlord who wishes to make $40 \mathrm{~s}$. freeholders to make to each a. lease for one life, at a rent which makes the qualifieation menely nominal, and puts the freeholder completely in the power of the landlord? Would it be robbing the poor if the landlords, instead of giring a 40s. frechold, gave a freehold of 210 annual ralue? Iet no recollect that the landlords will, after the mensure, want $£ 10$ freeholders as they now want 40s. freeholders. They may, perhaps, not. make so many of the one as of the other; but erery 210 frecholder would be a comfortable person. Who will say that the 40 . fine:olders are so?"

After reading this sophisticated defence of a sweeping nicasure of unjust disframelisement, the association passed a unanimous vote, deelaring, in the strongest terms its " undiminished and undivided confidence in Mr. O'Connell." Are we to be surprised then that there were many staunch reformers who hesitated in giving in their adhesion to a cause, the suceess of which was to be gained by such abandonment of all the principles of reform ? 
I do not absolve from the charge of bigotry and intolerance a party of men in Manchester who bitterly opposed themselves to Catholic Emancipation. They had no objections to endowment-if they had all the endowment to their own church; they had no objection to sweeping disfranchisement-they would gladly have added the English forty-shilling freeholds to the Irish, and swept them away all together. Neither reformers nor friends of religious liberty, they were actuated only by a deep hatred and a frantic fear of the "papists." An honest hatred and a real fear no doubt-a kind of protestantism run mad, and therefore about as much to be pitied as condemned. The same class of persons, thirty years earlier, would have pulled down Presbyterian chapels, and thought they did God service. In March, Sir Francis Burdett's resolutions for the relief of the Irish Catholies were carried in the House of Commons by a majority of 247 to 234 . The ultra Protestants of Manchester came to the rescue of the "constitution," and at a meeting convened by private circular, and held privately on the 22nd of April, they passed strong resolutions against any further concessions to the papists. The petitions founded on these resolutions were sent on the Saturday and Sunday to the ministers of the Methodist, Independent, and Baptist denominations, with notes requesting that they would allow the sheets to be sent to their chapels for the purpose of receiving the signatures of their congregations, The Independent and Baptist ministers, without concert, declined to allow the petitions to be received in their chapels. The Unitarian ministers were not asked for their co-operation. On the 25th of April, the Duke of York, who was a bishop as well as a general, strengthened by the movement in Manchester and other towns, made his famous declaration, immediately printed in gold, and sent to all parts of the kingdom. "Twenty years," he said, "had clapsed sinco the subject was first launched; its agitation had been 
the source of the illness which had elouded the last ten years of his father's life; and, to the last moment of his existence, he would adhere to his principles,-so help him Gon!"

The friends of eivil and religious liberty, not frightened at the declaration, on oath, of the pious prince and bishop, resolved that a publie meeting should be held to counteract any effect that might have been produced by the resolutions passed in private, but paraded as if they had emanated from the inhabitants of Manchester. The meeting, conrened by the boroughreere, was held on the 5th of May, in the Manor Court Room, whieh was excessively crowded on the occasion. Mr. John Douglas mored the first resolution, which was sceonded by Mr. George W. Wood, who, in the course of his speceh, animadverted very strongly on the proceedings of the hole-and-corner meeting which had previously been held. This called up Mr. Benjamin Braidley, afterwards boroughreeve, and a candidate for the representation of Manchester, who, certainly with great boldness, defended the private meeting, and moved that the discussion of the question in a place which could hold so few of the Protestants of the town was not expedient, and would give rise to unpleasant feelings. Mr. John Shuttleworth made an uble and a cutting reply. At this stage of the proceedings, a man in a fustian jacket, who was recognised as an operative cotton spinner, named Jonathan Hodgins, who had previously taken part in some meetings against the combination laws, modestly stood forward and inquired if a working man might be permitted to address the mecting. Of course he was permitted, and by his plain and unpretending manner, lis sound sense, and his not unfelicitous expression, soon rivetted the attention of the meeting. His speech is worth recording, as amongst the first delivered by a working man, taking his place amongst able speakers, who held high commercial rank in the community:- 
"I come forward with the view of arguing the question now before the meeting, with working men like myself, of whom I see a good many here. I know that there are gentlemen present, of great eloquence, and much better qualified than I am to discuss this question; but then their eloquence is not always convineing to the working man's mind, because it is frequently abore his comprehension; it is a dish of fish that ho does not understand. (A laugh.) Now $I$, who am a working man myself, hare paid some attention to this subject, and haring formed certain opinions upon it, I now come forward to deliver those opinions to my fellow-workmen. In the first place, I beg to nake a few obserrations on the speech of the gentleman who spoke the last but one (Mr. Braidley.) I eannot help thinking that he wishes rather to inflame our passions than to speak to our understandings. I am no Catholic myself, and have no passions on this subject to be inflamed; but $I$ think it would be better if we were all to confine our obserrations to the measure now before parliament, and not wander into long discussions about transubstantiation, and other matters which we none of us understand. (Cheers.) With the arguments which the gentleman founded on what the Catholics hare done in former times, we hare really nothing at all to do. (Cheers.) What was done we cannot tell with any degree of certainty ; for a great number of charges whlch are made by the one side are positively denied by the other; and whieh speaks the truth we hare no means of knowing. But of one thing we are tolerably certain; for it is proved by impartial historians of all parties, that, at all times and seasons, both l'rotestants and Catholies hare gone to extremes and extraragances-(loud eheers); and as all parties have been guilty, it would be the extreme of injustice to infliet punishment on the hundredth generation of the Catholics for what was done by their forefathers. (Loud cheers.) One argument which has been used against Catholic emancipation, amongst that class of persons to whom I belong, and to which I now address myself, is that they have the same elanee of becoming members of parliament as other people, if they would conform to the same opinions : but do you not see this sort of argument would go to justify erery sort of tyranny? It would justify Ferdinand and the inquisition in Spain. If a Spanish Protestant were to complain that he was exeluded from eivil rights, ho might then be answered by some Roman Catholie,- ' You hare only to do as we do; become a Catholie, and you will be entitled to the same privileges with us.' (Cheers.) This was something like the legislature passing a law that all men with wooden legs should be 
hanged; if a person who had the misfortune to be in that condition should eomplain of the law, on the prineiple I have alluded to, a man who had both his legs might say to him, 'It is the same for one as another; you have the same cliance as I lave; for if $I$ had a wooten leg I nust be hanged too.' (Cheers and laughter.) It would scem that the Catholics can get all they want in the easiest manner imaginable; for they have onty to take an oath to be admitted to the sane privileges as Protestants. Now, as the gentlemen say they care nothing about oaths, and can break an oath at any time, why need they bother about enaneipation? (Tremendous eheering.) I now beg to make a few observations on what Mr. Peel said on this subject in the IIonse of Commons, if a working inan like myself may be allowed to comment on the speech of a minister of state; and I would here observe, that I do not find fault with Mr. Peel for opposing Catholic emancipation. If he honestly thinks it would be dangerous, he does right to oppose it to the utmost of his power. I think it wonld not be dangerous, and therefore do not oppose it. I think the opprosition to it arises from unfounded prejudices; but I hope the time will come, and before long, when eren the prejudices of Mr. Peel will disappear, and when Catholics and Protestants shall take each other by the hand, and bury their discords and animosities in oblivion. (Lond eheers.) Mr. Peel, in his last speech, drew an argument from what has been recently going on in France. It secms they have passed somo sort of a severe law in that country, about what they call sacrilege; and Mr. Peel maintained that on that account we ought not to emancipaste the Catholice. But if the French are illiberal, I do not see why we should become tyrants. (Cheers.) There are in this country a many Cutholics, and a great many Protestants. Inet us all consult each other's interests, and cultirate each other's good will. (Cheers.) Let us live together as one people; and let foreign nations, if they will, pursue tyranny, till tyranny pursues them." (Lond clieers.)

The original resolutions were earried by a great majority, although two or three speakers, with much fury of utterance and much frantic gesticulation, attempted to convince the meeting that the liberties of the people would be destroyed if any Catholic was allowed to take a seat in either house of parliament. The time for emancipation had not come. On the 17th of May the Catholic Relief Bill was 
rejected in the Lords by a majority of 178 against 130 . The bill for disfranchising the forty-shilling frecholders was withdrawn.

At the time when the meeting in favour of eatholie emancipation was held in the Manor Court Room, it appeared to me that there was such an equality in the numbers in Manchester of those who were favourable and those who were opposed, that nothing short of actual enumeration could have decided which was in the majority. There were many, however, who, so far as any public manifestation went, might be supposed to be neuter, but who, if canvassed, would have given their suffrage in farour of the abolition of all those exclusive statutes which were in force against those who did not profess the state religion. There were many who deplored the errors and the superstitions of the Church of Rome, who were, at the same time, convinced that thuse errors were only the more pertinaciously adhered to because that chureh liad been proscribed and persecuted. They had seen that penal and exclusive statutes had only wedded the people of Ireland to their ancient faith. They had seen cetholicism strengthened by the very means used for its suppression; and they now wished to see its professors emancipated from their disabilities, in order that the irritation, which always is the result of oppression, might cease, and that, in the succecding ealm, reason and truth might exert their legitimate influence. That such irritation paralysed all protestant effort, however kindly intended, there was abundant proof. The Rev. and Hon. Baptist Noel, at a meeting held in Leels, in April, 1825, declared that, in his efforts to establish in Ireland auxiliaries to the Hibernian Society, he had found the refusal of civil privileges to the catholics one of the greatest obstruetions to the success of the society. It irritated them against the protestants, and made them suspect ererything from that quarter, insomuch that one intelligent individual in that country said, "You 
might as well hope to do good by sending tax-gatherers as by sending preachers, so long as this system continues." Mr. Baines, of the Leeds Mercury, who had all along manfully fought the battle for emancipation, in reference to $\mathrm{Mr}$. Nocl's remarks, said :-

"Mr. Noel gave no opinion about eatholic emancipation; he especially declared that he should pronounce no opinion on the subject; but these facts he could not eonceal-they stared him in the face whererer ho went; and he feels bound to deelare to the society in England what he felt to be the greatest praetical impediment to his benevolent exertions. Mr. Noel is a most unexceptionable witness; for the treatment he reeeived in Ireland would tend to impress him, not in favour of the eatholies, but against them, if his superior intelleet had not penetrated to the causes of things, and found that it was the English system, and not the Irish eharacter, that was to blame."

With such evidenee of the results of exelusion from civil rights, I saw a growing disposition in farour of a change of mcasures, and this disposition, I was convineed, had neutralised many whose dislike to popery might otherwise have made them the determined opposers of erery proposal to release eatholicism from the bonds which were imposed upon it by the fears or the hatred of a less enlightened and less tolerant age. Mr. Oxlad, a baptist minister, made an eloquent speech, at Chester, in which he expressed the sentiments of many who were beginning to think that a blind opposition to the clains of eatholics was not the best way to promote the interests of protestantism. He said:-

"Aspiring demagogues, enlisted on the side of popery, can only succeed where the people hare their minds irritated into asperities by political injuries. Where they huse the means of education, admit. them to equal rights-allow them no pretence for eomplaining as. citizens, and your turbulent demagogues lose their influence-find no materials to work upon, and they are deprived of the only vantage ground on which they can ever stand. The political diseontents of the catholics are the only reasons for alarm, for which emancipation is the only cure, and for which our opponents can advise no substitute 
but the augmentation of the discontents. Oppress them, and you make them your enemies, and awaken, if you do not justify, their rage. You have been exhorted this morning not to suffer the claws of the lion to grow which your ancestors pared-the propriety of which metaphor I shall not question, and only add, that it would be well to remember, the lion, when starved and ill-treated, becomes rampant and outrageous. Whilst, however, I differ from many in eatimating the danger of popery, I do not stand up to defend or excuse the system. I speak as a protestant, and a protestant dissenter; and without intending any disrespect to the respectable catholic clergymen present, I freely declare my abhorrence of popery; I long for its overthrow; and would not support the cause of emancipation if I thought it would in any degree delay this consummation of $\mathbf{m y}$ wishes."

There were still many persons who really feared the revival of the fires in Smithfield, if the laws against Catholies were made less stringent. It was worth while to show these timid people that protestantism could persecute in its turn. In an article in the Gazette, I enumerated some of the horrible atrocities perpetrated in Scotland, in the time between the battle of Bothwell Brig, in 1679, and the revolution of 1688 , and said :-

"Bo it recollected that these atrocities were not committed by tho papists. Protestant blood was shed by Protestants. The deadly persecution was not directed by the Cliurch of Rome against those she considered hereties, but by the I'rotestant Fpizcopsl Church of England against the Protestant Presbyterian Church of Scotland. Does any one fear that a conrenticle will now be attacked, sword in hand, because the preacher has chosen to be ordained by his co-presbyters rather than accept of episcopal ordination? The doctrines and government of both churches remain the same; but there is a change in the spirit with which the doctrines are held and the government administered; and with the examplo of this change amongst the members of the Church of England, and the substitution of a liberal and tolerant for a bigoted and intolerant spirit, wo are justified in believing that whether the doctrines of the Church of Rome be changed or not, there is such a charge amongst its members, so far as the spirit with which those doctrines are held, that persecution of any other sect would not now be attempted. For oursclves, wo have 
no more apprehension of seeing Fnglish liberties exposed to danger by Roman Catholic influence, than of seeing a Scotch Presbyterian shot by the direction of an Finglish Protestant bishop, for attending. a prayer meeting. Such things were; but he is ignorant of the spirit of the age, and the character of the people of these realms, who feare that such things may now be. Were eivil privileges withheld from all those who hold the same opinions which were entertained by the intolcrant two centuries ago, we suspect that the members of many religions seets would habour under the disadrantages of exclusion. It is peculiarly gratifying to all who value the nild and gentle spirit of Christianity, to see that those who seek in the sacred rolume not only for comfort and consolation under the evils of life, but for rules of conduct, are becoming more and more convineed that it is docidedly opposed to every species of persecution on account of opinion; and that the unholy zeal which aetunted the apostles against the Samaritans, when they solicited the Lord to 'command fire to come down from hearen and consume them,' is yielding to the spirit of the rebuke with which the call was met."

At the beginuing of $1825, \mathrm{Mr}$. 'T. Sowler established the Manchester Courier. The tory and anti-catholic gentlemen of the town imagined that they were not sufficiently represented in the press. They had seen the whig Guardian in three years and a half attain a circulation of 2,200 , and the sale of the whig-radical Gazette in half a ycar after it had been $m y$ property advaneed from 1,000 to 1,500 , each with a proportionate share of advertisements. There were four other newspapers, the Mercury, the Chronicle, the British Volunteer, and the Exchange Herald; the three first were ultra tory, the last what would now be called conservative, but the circulation of all together not amounting to so much as that of the two liberal papers, both of which were progressive, while the others were retrograding. Mr. Wheeler did not think his Chronicle needed improvement; Mr. Harrop left his Mercury and British Volunteor to be compiled by his compositors from the files of London and provincial papers, each, seissors in hand, cutting out, as "copy," what suited his own taste in politics or poetry, dog fighting or horse racing; and Mr. Aston was too gentle 
and too benerolent to make his Herald the rehicle of any fierce discussion. A new tory paper was necessary, and Mr. T. Sowler was ehivalrous enough to undertake to find his party an organ. The object was to counteract the influence of the whig and the whig-radical press. Mr. Taylor had the reputation of knowing something more than the value of raw cotton, and I was understood to know a thing or two beyond Glasgow muslins and Manehester shirtings and ginghams. It was desirable that the editor of the new paper should be a man of literary reputation-an author by profession-one whose name in the republic of letters should seare out of the field the men of cotton bags and eambrics. Mr. Alaric Watts was the chosen champion, a writer of some pretty poetry and some oharp criticisms on the fine arts, and, besides, a member of the cliques of London literati-execllent editorial qualifications, no doubt; but, unfortunately, he knew nothing of political scienec, and, as a poet, had disdained to aequire any knowledge of political cconomy. I had a brief tilt with him, but soon returned to the rule I had laid down, rather to teach truths than to be combatting against easily-refuted error. The Guardian and the Cuurier, howerer, found it convenient to continue the warfare. It was an easy thing to vindicate toryism by attacking the whig Guardian, and it was as easy to vindicate whigism by attacking the Courier. By continuing this warfare the publie might at length be led to believe that there was no other party in Manchester than the party whig and the party tory, and that there were no other papers than the Guardian and the Courier that represented any portion of public opinion,and so the tilting has continued from that day to thisalways, and even now, as if there were some real points of difference between them. The meeting in the Manor Court Room in favour of Catholic emancipation set this petty quarrel a going. The Courier said that one half of the requisitionists were Unitarians; the Guardian, that this 
was false. The Courier called for the names of those who were not Unitarians; the Guardian called on the Courier to name those who were Unitarians; and so the discussion went on for weeks together!

The Pitt Club needing some revivification, Mr. Watts's poetical talents were brought into requisition. The Duke of York's health, for his "so-help-me-God" speech, was given with three times three eheers and three cheers more. "The Cheshire Fox Hounds," coupled with the name of Sir Harry Mainwaring, had also three times three; and Watt's bacchanalian song, which was sung with great glee, and the burthen of which was, that-

"One drop less than a bumper would not be-tho thing;

When the drinkers are tories, the toast is the king," procured for lim the same honour that had been conferred on the hounds. It was deseribed as a "most cordial and convivial meeting," for there was plenty of noise and plenty of wine, and every man appears to have cordially agreed with the maker of the song-

"Let whigs drink and be dumb-ice will make the roof ring !" " And they did make the roof ring with toasts the utterance of which would now be considered as an outrage to common deceney, even in a tap-room. These were the exultant days of a certain " eaptain," of whom we shall hear somothing in 1831. 


\section{CHAPTER XVII.}

\section{A PERIOD OF GREAT DISTRESS.}

Fros the real and the apparent prosperity of this period, arose the proposal of some really useful public undertakings, some of which were afterwards carried into effect. In the Manchester Gazette, of the 1st of January, 1825, are the resolutions of a meeting to form a railway between Manchester and Bolton, with a capital of $£ 100,000$, a sum found to be rery inadequate to the object. In the same paper is the prospectus of a railway from London to Manchester, by way of Birmingham, to be afterwarls extended from Manchester to Hull; the sum proposed for this great work being only $£ 2,500,000$. In the paper of January 8 th, is the prospectus of the Manchester and Leeds Railway, with a proposed capital of $£ 500,0$. 0 . In the same paper is a notice that 1,000 shares, of $£ 100$ each, had been subscribed for the Manchester, Stockport, and Peak I'orest Railway, and that double the amount would be sufficient for the purpose. In the paper of January $15 \mathrm{th}$, is the prospectus of the Grand Junetion laalway, with a eapital of $f^{2}, 000,000$. On January 22ud, appears the prospectus of the Manehester Centrnl Junction Railway, to connect Manchester, by a line passing through Stockport, Chelford, Congleton, with the propesed line from Liverpool to Birmingham. On January 29th, there is the prospectus of a Manchester and Oldham Railway. On February $5 \mathrm{th}_{\mathrm{h}}$, there is the prospectus of a ship canal from the mouth of the river Dee to Manchester, -a project much laughed at and derided, but which will probably be revived, with better effect, at some future day. On the 12th of February I find the resolutions of the Committee of the Manchester and Liverpool Railway, and 
an announcement that a petition to the House of Commons in its favour will lie at the lixclinge Room for signature. These were some of the more sober schemes of a period which was charicterized by the wildest speculation.

There is a class of persons who imagine that every depression of trade might be arerted by a liberal issue of paper moncy. The extension of the currency in the years 1823-4-5, had encouraged a spirit of speculation which pervaded the whole country. Men there were then who held that nothing more was necessary to secure the continuance of apparent and, as they supposed, real prosperity, than the issue of more "promises to pay." The nation was drunk, and the preseription of the currency doctors was to increase the potency of the exhilarating draught. But the foreign exchanges were against us; gold began to leave the country, and the Bank of England had greatly to limit its issues, to prevent its coffers being drained of the precious metals. The country banks had deluged the country with one-pound notes, and the facility of obtaining discounts had encouraged the mamufacture of a large amount of accommodation bills on the part of merchants and traders, who were in haste to make hay while the sun shone. It was obvious that such a state of things could not continuc. In Manchester and its inmediate vicinity, the issue of small rags had been steadily discountenanced, and, in consequence, the paper transactions represented, in a great degree, actual sales; nnd there was in circulation a grenter proportion of Bank of England notes, and of gold and silver, when compared with the paper issued by provincial banks, than there was in any otlier part of the kingrlom. But the country could not generally suffer without involving Manchester in the calamity. 'The country bankers, by the end of November, 1825, hegnn to make heary demands on the discounting houses in London. One house, which used to have about thirty applications on a Monday, had, on Monday, November 28th, no fewer than three hundred. 
The failure of Sir William Jiford's bank, at Plymouth, added to the alarm in the London money maket, and u run on the Plymouth banks forced the banliers into London to obtain, at any cost, the means to meet the sudden demand. The failure of the great bank of Wentworth and Co., Wakefield, added to the general alarm in the metropolis, and occasioned quite a panic in the manuficturing distriets in Yorkshire. In Manehester the eirculition of provincial notes was instantaneously stopped. Every one hastened to pay away what he had, but no one would receire them; and every note (except those which were payable there, and which were promptly exchanged for grold, till long past the usual banking hours) became, for the time, nothing more than waste paper. In the corn market business was almost entirely suspended; cheese, which hatd been weighed out by the ton for the country shopkecpers, was put back again when it was found that the buyers had nothing to pay with but country paper; and the shopkecpers, in many instances, ehose rather to give eredit to persons who were almost strangers to them, than to take payment in a medium which had ceased to be current.

The general alarm was greatly inereased when, on Saturday erening. December 10 th, it was annomeed that the London bauking house of Sir Peter P'ule, Bart., Thornton and Company, had determined not to open their doors on the Monday, and that Dobson and Co., of IIuddersfield, had stopped payment. The run on the banks in Wakefield, Huddersfield, and IInlifax was terrifie, but timely supplies and declarations of eonfidence from the leading manufacturers sustained them in the emergency. From Oldham to Dobeross the road was a scene of complete hurry and bustle, tradesmen and manufacturers being scen hastening on their way to exchange the paper of the sitctlleworth banks for gold. On the Weduesday bills were distributed, to which were attached the signatures of upwirds of two hundred individuals or firms, stating that " the undersigned, feeling 
satisfied as to the responsibility of the two respectable banking houses of Buckley, Roberts, and Co., and Harrop, Brown, and Co., of Saddleworth, and foresecing the ruinous consequenees to trade which must be produeed by suddenly withdrawing from circulation the provincial promissory notes, do hereby express our determination to take their notes, as usual, to any amount." 'This publication restored confidenee in the stability of the Saddleworth banks, although from Manchester there was a continued demand upon them for gold in exehange for their paper, influenced by some resentment that after former efforts to get rid of their notes there should still be so many of them in circulation. In my paper of December 31st I find the following list of the failures of country banks :-

Ashburton.-Brown and Co. Will pay erery demand in January. Alton.-Levy and Co.

Banbury. - Gillett and Co. Stopped in consequence of the failure of Gibbons and Co., Birmingham.

Bedford.-Rawlings and Co.

Birmingham.-Gibbons, Smith, and Bood.

Boston.-Ingelow and Co.

Bristol.-Brown, Cavanagh, and Co.

Bath.-Caranagh, Brown, and Co., and Smitl, Mojer, and Co.

Bradford, Wakefield, and York.-Wentworth, Chaloner, and Co. Brighton.-Lashmal and Muggerilge, and Gregory, Tamplin, and Greary.

Chellenham and Gloncester.-Turners and Morris.

Terckesbury and Exesham.-Hartland and Son.

Cherlsey.-Lacoste and Co. Since resumed.

Cambridge.-Hillow'k and Co.

Chelmugord.-Cmket, Russell, and Co.

Darentry.- Watkins and Co. In consequence of the suspension of Sykes and Co.

Dorchesler.- R. I'nttison and Co. In consequence of the suspension of Williams and Co.

Dorking.-Piper and Co.

Decomport.-Shields and Johns.

Darlington. - Skinner and Co. Since resumed.

Deal,-May and Co. 
Diss.-Fincham and Son.

I Falmouth.-Carne, Lake, and Carnes.

Gracesend.-Branchley and Co.

Hereford.-Garratt and Son.

Binckley.-Jervis and Co., and Sansoms and Co., who both drew on Sir P. Pole and Co.

Hwddersfield. -John Dobson and Son.

Kettering.-Gotch and Son, and Keen and Co.

Kingston (Surrey).-Shrubsole and Co.

Levoes.-Wood, Hall, and Co.

Leicester.-Clarke and Phillips. All demands seem likely to be paid in full.

Maidstone.-Edmeads, Etkins, and Tyrell, who drew on Sir P. Pole and Co.

Monmouth.-Sneed and Co. Notes still eurrent.

Melksham.-Mowle, Son, and Co. Will soon resume.

Malton.-Crichet, Russell, and Co.

Nantwich.-Broughton and Garnett.

Newcastle-under-Lyne.-Sparrow and Co.

Norucich (and carious branches).-T. II. and W. Day.

Northampton.-Smith, Osborne, and Co.

Peterborough.-Simpson, White, and Co.

Plymouth.-Sir W. Elford and Co.

Poole and Wimborne.-Dean, Clapeott, and Co.

Romford.-Joyner and Co., who drew on Esdaile and Co.; and

Joyner and Co., who drew on Gill and Co.

Ripon and Knaresbro'.-Charnock and Thekray.

Saffron Walden.-Searle, Son, and Co., and Searle and Co.

Southampton.-Killon and Pritchard. IIarc fixed an carly day for payment of notes.

St. Neot's.-Rix, Gorham, and Co.

Sheerness.-E. Bishop.

Stockton.-Hutchinson and Place.

Sxansea.-Gibbons, Faton, and Co.-and Haines.

Terkesbury.-Hartland and Co.

Weymouth.-Henning, Bower, and Co.

Wellingbro'.-Morton and Co.

Winchester.-Deane and Co. Since resumed.

Windsor.-Ramsbottom and Leigh.

Wimborne.-Dean and Co.

Wisbeach.-Hill and Son.

Whitehaven.-Johnson, Adams, and Co. 
The fiilure of so many country banks caused an almost umparalleled number of bankrupteies anongst country drapers, and these failures bore very heavily on the wholesale houses in Manchester, London, and Bristol, who were also, generally holdling large stocks, greatly sufferers by the sudden fill of the prices of goods. For a time the home trade was completcly paralyzed, and the manufactures which should have gone to the home supply were thrown upon the forciun market, working ont a further reluction of prices. Under these circumstances manufacturers ceased to produce, and tens of thousands of the working classes were at once thrown out of employment, who bore their distress with most exemplary patience. For a year and a half I had applied myself as a jonrnalist to explain the circumstamces which regulated the wages of labour, and had sueceeded in convineing such of them as were able to buy my paper, at a time when government exacted a duty of threpence furthing on erery newspaper sheet, that a reluction of prices was oceasioned, fir less by the grasping cupidity of masters, than by a mistaken or a selfish legislation, under which masters and men suffered alike severely. This conviction did mueh to prevent that bitterness of feeling which had bren the occasion of many long-enduring contestis between cmployers and employed. $\Lambda$ number of persons so instructed, secing that the com laws, in their double operation of limiting the demand for labour, and consequently its reward, and raising the price of food, were deeply injurious to the manufacturing interests of the country. resolved to hold a meeting to petition for their repeal, and it was held in the Manor Court Room, on the 24th of Jinuary, 1826, and was attended ly from 1,500 to 2,000 persons, principally of the working classes; but amonget them were a considerable number of the more wealthy inhabitants of the town, attracted less, perhaps, by the importince of the subject to be discussed, than by a desire to be auditors of an eloquence which few supposed 
to be possessed by the working people, till I had given reports of some of their meetings, which, previously, the Manchester newspapers had passed over without notice. A working man was called to the chair, and requested attention to every speaker, whether his sentiments were or were not in accordance with those of the meeting generally, Another working man, named Foster, who had taken an active part in promoting Hobhouse's bill for shortening, with the consent of the principal master cotton spinners, the hours of labour in factories, proposed the first resolution. He said, that the landed interest, in order to shift the burthen of taxation from their own shoulders, had thrown it upon the shoulders of the manufacturers, and that they, in their turn, had to give less in wages, and thus the load came ultimately to be borne by the working classes. He congratulated the meeting that they could now meet to give expression to their grierances, and that they did not now assemble to attack the butchers' and bakers' shops, but to petition against the eontiuuance of laws which were injurious to all elasses of the community except the landlord class. Jonathan Hodgins, who had distinguished himself by his speech on Catholic enancipation, in seconding the resolution, said that the time had been when masters and men eontended with each other, but now they might cordially unite to give a decisive blow to the system which imporerished them both,-a eystem which, more than all the tyranny that enployers had ever exereised, tended to oppress the people. It is rather curious that when a dinner, some twenty years after this period, was given by the Finglish merchants of St. Petersburg to Mr. Cobden, this same Ifodgins should rise up and argue in favour of the continuanee of the corn-law ! He had been engaged as the manager of a cotton mill in Russia, and the humble salary at which he was first employed had been gradually raised till he was in possession of an ineome of $f 600$ a year. The meeting of the merchants and manu- 
facturers of Manchester had been to obtain a revision of the coru-laws; the meeting of the working classes was to pray for their total repenl.

While the working men were thus proving their capacity to excreise politienl rights, the boroughreeve and constables manifested a spirit which was worthy of the palmiest dnys of the church-and-king clulss. A requisition was presented to them on the first of February to call a public meeting to consider the propricty of petitioning parliament on the subject of negro slavery in our colonies, and in support of his majesty's government in their leclared intention to ameliorate the condition of the slave population. It was signed by 153 indiriduals of the highest respectability, and the subject proposed to be discussed was one which, however viewed as to its humanity and poliey, could not by any possibility lave given rise to that warmth of contention which oceasionally took place when political parties came into collision. The requisitionists asked no more than that their fellow-townsmen should be ealled together to consider the propriety of petitioning the legislature to give effect to its own resolutions. 'That a refusal would be given to such a requisition, no one could have anticipated; for even supposing the gentlemen who filled the offices of boroughreeve and constables to be so unfortunate in their opinions as conseientiously to believe that nothing should be done to ameliorate the condition of slaves, no one could have inagined that they would have stood in the way of the support which their townsmen, by a public expression of their sentiments, were clisposed to give to his majesty's governument. So little was it auticipated that these gentlemen would put their veto to such a requisition, that when the question was asked what should be done if they were unwilling to call a meeting, such a result was considered too improbalble to make any nlterior measure a matter of diseussion. They dicl, however, refuse. The boroughreeve and constables of Manchester did actually refuse to 
convene a meeting, at which it was proposed to strengthen the hands of his majesty's ministers, by a public expression of the approval which their humane interposition in behalf of the injured negro race had obtained from all ranks and every party. " After much consideration," said they, "we have felt it our duty to decline calling the public meeting proposed in the highly respectable requisition presented to us this day !" In Bristol, or in Liverpool, while the inhabitants were fully engaged in the guilty traffic of buying and selling their fellow-men, and when self-interest warped the judgnent and deadened the sense of justice, and humanity slept, and the cry of God's creatures was unheard except in heaven-in such times a refusal to call a meeting might not have been thought wouderful, though even there the refusal on the part of municipal officers might have been considered an ungracious prejudgment of the question which it was proposed to discuss. The boroughreere was Mr. William Lomas; the constables were Messrs. Charles Cross and J. B. Wanklyn. Their refusal did not, however, prevent the meeting being held, and from that time to the total abolition of slavery Manchester took a prominent part in the humane movemeut.

The manufacturers of Manchester and its vieinity, in the belief that the prosperity of 1824 and 182.5 would continue, had been producing largely, and had considerable stocks on hand at the termination of the latter year. The sudden and extraordinary depression of trade made it unprofitable to produce more until prices had found their lerel; and although a humane consideration of the distress of the working classes led many to strive to keep on a portion of their hands, a very great number of them were thrown out of employment. For the relief of these, "subseriptions were raised in most of the manufacturing towns, and in Manchester the amount subscribed, by the end of April, 1826, exceeded $£ 8,000$, which was expended in a weekly distribution of provisions. The unemployed had borne their 
privations with a most exemplary patience; but the uninstructed multitude began to think that the extensive use of machinery was a main eause of their distress; and as the hand-loom weavers were more out of employment than any other class of operatives, they attributed their wretehedness to the introduction of steam-looms. This was a class of workers who, eren when in employment, eould not afford to read a seren-penny newspaper, which might have been threepenee-halfjenny but for the goverument tax. There was a heary penalty on the aequisition of knowledge, and they remained ignorant; and an ignorant is seldom a peaceable people. At $A$ ecrington, on the evening of Tuesday, April the 18th, a mob of probably two thousand persons assembled round the steam-loom factory of Messrs. Sykes, and proeceded to break the windows. The manager, who went out to address the misgnided multitude, was assaulted and treated very roughly, and, fears being entertained that still greater violence would be resorted to, the military were sent for. On the following evening, when the market coach from Manchester arrived at Blackburn, it was assailed by a crowd of people, who showered stones upon it, and some of the manuficturers, who were in and upon it, received severe bruises.

On the evening of the day on which disturbanees were commeneed at Aecrington, Mr. Whitmore brought on his motion in the House of Commons for a committe to inquire into the operation of the corn-laws. It was strenuously opposed by Mr. Huskisson. IIe had promised, in the previous session, that the question should be brought before the house, but the circumstances of the country, he said, were now different; the subject required a more scrious considerution than could now be given to it; anxious as be was for free trale, it would be highly impolitic and injurious to repeal the corn-laws; it would tend to aggravate rather than lessen the evil! This was uttered at the very moment when starving weavers were attacking power- 
loom factories-uttered at the very time when there was abundance of wheat to be had on the continent at half the price to which the corn-laws had raised it in England. The house supported the minister of trade. There were only 81 rotes in favour of Mr. Whitmore's motion, and 251 against it. I remarked on these coincidenees :-

"While we would strongly mark our condemnation of every aet of violence, whaterer may be the actuating canses, and whatever excuse extreme wretchedness may give, we feel it our duty to say that if the legislature do not immediately adopt measures for the alleriation of the distresses of the people, it will incur all the guilt of permitting thousands to die of actual starvation. By a reference to a table of prices of grain at different foreign ports, which will be found in the first page, it will be seen that the monopoly enjoyed by the owners of the soil in this country has raised the price of corn to nearly double what it might be were the trade open. Will any man, not wilfully blind to the truth, dare to assert, that while the people are starring, things ought to remain in this state? We had hopes that the liberal spirit which has been recently shown by the administration would be eommunicated to that houso which ought to represent the people, and that this odious and oppressive monopoly would be destroyed; but the result of Tuesday nigltit's debate on the corn-laws has driven us back to our old convietion, that, constituted as the house now is, the interests of the indiriduals who compose it will always be regarded in preference to those of the community."

The disturbances at Acerington and Blackburn were only' preliminary to others of more serious consequences. On Monday, $\Lambda$ pril 24 th, a great number of persons assembled on some high ground at Henfield, between Blaekburn and Burnley, from whenee they proceeded in a body to Acerington, where their arrival had been fearfully expeeted. They immediately surrounded the mill of Messrs. Sykes and Co., and a part of the body entered the mill and began to demolish the power-looms, sixty in number, which, in the short space of a quarter of an hour, they broke completely to pieces, destroying also the dressing machines, and materially injuring the engine. They then proceeded to Rough Hey, 
where twenty looms in the finctory of Mr. Walmsley were smashed to pieces. Mr. Bury's factory at White Ash was next attacked, and the power-looms, eighty in number, were demolished. The military were ealled in, but the rioters had finished their work and were on their march to Blackburn. There they immediately proceeded to the factory of Bannister, liceles, and Co., where they deliberately destroyed the looms. A troop of thirty soldiers was drawn out, but could not act, as there was no magistrate present to direct it. The finetory of MIr. Oughton, at Grimshaw Park, was next attacked, and twenty-four looms broken. The solliers arrived nearly as soon as the rioters, and were assailed with stones. In firing in return there was one man killed and two dangerously wounded. The rioters then retired to Blacklurn for the night.

On 'Tuesday an attack was make on Turner's mill, at Hclmshore ; but, a small body of the Queen's Bays muking its appearance, the rioters fled, leaving, however, fourteen of their number in the mill, who were taken into custody while engrared in the work of demolition. They were conreyed to Haslingden; but there the fury of the multitude was so grest, that it was thought prudent to set them at liberty.

On Weduesday morning, several hundred persons collected at hawtenstall, and commenced the work of destruction by demolishing one hundred looms, in the factory of Messrs. Whitchead. The mob, then, with a great accession of numbers, procecded to Mr. Kaye's mill, at Longholm, where, in a few minutes, they destroyed about twenty looms. The next attack was upon the factory of Rostron and Sons, at Edenfield, where one hundred looms were instintly broken to pieces. The rioters then proceeded towads Chadderton, and were met on the road by a small party of soldiers, accompanied by Mr. William Grant, one of the county magistrates-a man of great benerolence, and much beloved and respected by the country pcople- 
who addressed them on the folly and wiekedness of their conduct, and urged them to return to their own homes. His adviee was disregarded, and the liot Aet was read. This had the effect to disperse them for a time; but they re-assembled, and proceeded to Aikin and Lord's fuetory. Here, being kept in cheek by the military, they could do no misehief, and they moved in the direetion of Ramsbottom, followed by the soldiers. The field being elear, a number of persons who were left behind foreed themselves into the factory and destroyed the whole of the looms. 'The soldiers were recalled, and on their return were assailed by the mob, who showered stones upon them, by which several were severely hurt. They were then ordered to fire, and the consequences were that three men were killed on the spot, and a man and woman were wounded, both of whom died in a few hours afterwards. The nob now divided into two bodies, one of which went off in the direction of Bacup, the other in the direction of Bury. The latter attacked the faetory of Hamer and Son, at Summerseat, and in the course of ten minutes broke thirty-eight looms. They then went to MIr. Whitehead's factory, at Woodhill, eluse to Bury, where they broke thirty-eight looms. 'The body which had taken the road to Bacup, destroyed six woollen looms at Messrs. Ormrod and Son's, of Holt Mill, and also a few at Hargreaves' and Hardham's, Bacup. About five o'clock they broke open the door of Mr. Mumn's fictory, and a person who was present noticed that they were exactly thirty-five minutes in breaking the looms, 51 in number. This terminated the riotous proceedings of that day.

While these disturbances were taking place in the neighbourhood, very little apprehension existed that they would extend to Mauchester. Some alarm, howerer, was exeited on Thurslay, by a body of men marching through the principal streets in proeession, and by an anuouncement, that in the erening a meeting of those who were unemployed would take plaee in St. George's Fields. At six 
in the evening the proposed meeting took place. It was addressed by one or two individuals, who urged upon those who were present the neessity of standing firmly to each other, to destroy the power-looms, which, they said, were the cause of their being unemployed, and assured them no military force could withstand them, if they would only assert their rights like men. Amongst the persons led by curiosity to the place of meeting was Jonathan IJodgins, a man whose name had been made pretty well known by his plain and untutored eloquence, and who, feeling, as he afterwards assured me, that he should not do his duty if he did not oppose the mischicvous persons who endenvoured to excitc the people to violence, ventured forward, and suceceded in obtaining a hearing. Ife expressed his sympathy with the distress which probably all who heard him experienced, but he asked, could they relieve it by attacking provision shops, or destroying loons? "No," said he, " the only possible result of such violence would be, that they would suffer under the swords of the military, and that not the slightest alterution would be made in the system of which they complained. The parish was bound to support the distressed; and if the parish officers did not grant assistance, the applicants might appeal to the magistrate, who would order them relief. Till all these legal resourees were tried, every attempt to oltain their purpose by other means was illegal." Mr. Hodgrins's address was at first listened to with some impatience; and even when he had gained a favourable hearing from the majority, there was a manifestation of feeling amongst a part of the people which was rather alarming.

At this time I arrived at the outside of the assemblage, accompanicd by two young friends. In pressing forward to hear what was passing, the crowd fell awny on euch side, opening an avenue for our adsance. $\Lambda \mathrm{s}$ I was known to many working men, I thought I might have an opportunity of advising them of the consequences of the lawless pro. 
ceedings of the strangers who had eome to excite them to action; but I was somewhat alarmed when I saw that the opening made for our advance was instantly closed behind us, and that we were completely hemmed in. When we got into the middle of the eircle, Hodgins, thus reinforced, continued his address, and urged the mecting to petition against the corn laws, the repeal of which might give them some relief, and to refrain from violenee, which would only recoil upon themselves. I then got on a high pile of bricks and, what with the insecurity of $\mathrm{my}$ footing, the coldness of the day, and the apprehension that $I$ was making a rather hazardous experiment, I did not feel that I was standing very firmly on my legs. Some threatening eries were uttered, but were met by shouts of "IIear him." I told them that I had attended a meeting in the police-office that very morning, at which the individuals present had subscribed $£ 1,000$ as the commencement of a new subscription for the relief of the distress, although they had all been contributors to the $£ 8,000$ fund, which had already been expended; that the king had sent $f 1,000$ to the Manchester, the same sum to the Blackburn, and the same sum to the Macelesfield funds; that there was erery disposition amongst the merchants, manufacturers, and shopkeepers, notwithstanding the rery heavy losses they had recently incurred, and the large amount of poor-rates they had to pay, to do their utmost to relieve the distressed; and that there was ready for distribution next day nearly $20,000 \mathrm{lbs}$. of bacon, and more than $100,000 \mathrm{lbs}$. of meal. The announcement of this liberality was favourably received, and I went on to say that I had, for the last ten years, been an attentive observer of the conduct of the working men in Manehester; that I had never, during that period, scen any attempt of theirs to destroy private property, and $I$ begged and prayed, as they respeeted the reputation they had acquired for exemplary patience, that they would continue to manifest the same disposition; that they would 
not listen to the strangers who had come there to urge them to acts of violence and destruction, but would all follow me out of the field, and peaceably depart to their own homes. I then left the place, and was followed by probably 3,000 out of the 5,000 or 6,000 who had congregated. The rest remained on the ficld, mostly mere lads, mixed with the strangers who had come down the valley of the Irwell, marking their progress by destruetion.

I instantly gave notice at the polie:-office of the nature of the mecting, and urged the magistrates who were there assembled, in mercy to the lads who were likely to be led into violence, to send $a$ troop of horse into the neighbourhook, being assured that the very sound of their hoofs would disperse their erowds. One of the magistrates said it was rather inconsistent that $I$, who had found so much fault with the employment of soldiers on the 16th of August, 1819, should now recommend that they should be called out. I replied that there was no inconsistency in it: on the 16th of Augist, troops were directed against a legally convened and peneeably assembled meeting; here was a meeting, the avowed objeet of which was to destroy property, and might be dispersed by the mere show of power without bloodshed. The military were not in readiness till ten o; clock, and by that time Beaver's factory; in Jersey-street, had been set fire to in half-a-dozen places; and burnt down nearly to the ground. On the following day, the magistrates ordered the Qucen's Bays to parade the streets, and this had the effect of repressing the disturbances, which were confined to the plunder of some bread shops. 


\section{CIIAPTER XVIII.}

SYMTOMS OF MOVEMENT.

ON Monday, May 1st (1826), Mr. Secretary Canning announced that ministers intended to apply to parliament to rest in them the discretionary power to allow the foreign corn then in bourd to come into consumption, and to admit the importation of wheat, limiting the quantity to 500,000 quarters, at a duty of twelve shillings, asserting the emergency as a reason for a temporary deviation from the principle of protection. No discussion on the corn-law was permitted, both Mr. Canning and Mr. Huskisson declaring that then "was not the time." There was not a single argument used in favour of a temporay suspension of the eorn-laws that would not have been applicable to their total repeal. The admission of so mueh wheat which otherwiso would have rotted in the bonding warehouses, together with very liberal subseriptions in London and in all the large towns, and the prospeet of a great amount of employment being given in constructing the Liverpool and Manchester Railway, did much to allay the existing discontent, and to preserve the peace. An adnirable address to the unemployed, written from Rouen in France, by Mr. Edward Baines, jun., of Lecds, and widely eirculated amongst those classes which were unable to purchase the heavily taxed newspaper, had also a considerable effeet in showing that the extension of machinery had not been the cause of distress.

A general election took place during a period of almost unexampled suffering. The general body of the peoplo took no interest in the choice of members, who, in the then state of the representation, were only the nominees of the 
landed aristocracy, or of the owners of rotten boroughs. While the firree of election was going on all around us, I employed myself in examining the actual state of the represcutative system, and eulled out some proofs of the filsehood of denominating the members of the House of Commons representatives of the people. At the previous census, the population of the umrepresented parish of Manchester amounted to 187,031. Being desirous to ascertain how many represented boroughs would give a population equal to that of this large unrepresented parish, I set about adding up the numbers in each, and found that the population of one humdred boroughs, each sending two members, amounted to only 185,197 . The following is the list :-

\begin{tabular}{|c|c|c|c|c|c|c|}
\hline & & 2511 & ch ... & & & $?$ \\
\hline burton... & $\cdots$ & .. 3103 & wich ... & $\ldots$ & .. & \\
\hline & & .. 1212 & resham ... & $\ldots$ & .. & ... $\mathbf{3 4 8 7}$ \\
\hline & $\ldots$ & $\ldots 735$ & $\begin{array}{llll} & \ldots & \ldots\end{array}$ & & & ... 1882 \\
\hline & $\ldots$ & .. 2612 & enuy Stratfor & & & \\
\hline & $\ldots$ & $\ldots 1341$ & cy $\quad \ldots$ & $\ldots$ & & .1455 \\
\hline & $\ldots$ & $\ldots \quad 993$ & Galton & $\ldots$ & & \\
\hline Castl & e... & $\ldots 1850$ & Grimsby ... & $\ldots$ & & \\
\hline & $\ldots$ & $\ldots 1187$ & add... & $\ldots$ & & $\ldots 3153$ \\
\hline & $\ldots$ & .. 3278 & & $\ldots$ & & ... 316 \\
\hline & & $\ldots 860$ & & .. & & \\
\hline & & $\ldots 877$ & & $\cdots$ & & \\
\hline & $\ldots$ & ... 1851 & & $\ldots$ & & ... 267 \\
\hline & $\ldots$ & $\ldots \quad 98$ & & $\ldots$ & & 132 \\
\hline & $\ldots$ & ... 3165 & Ferrer: & & & \\
\hline & $\ldots$ & ... 1928 & & .. & & \\
\hline & $\ldots$ & $\ldots 2$ & & $\cdots$ & & ... 3296 \\
\hline & $\ldots$ & $\ldots$ & & $\ldots$ & & 2806 \\
\hline & 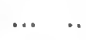 & .. 1321 & & $\cdots$ & & 2181 \\
\hline & $\ldots$ & $\ldots \quad 313$ & cr $\quad \ldots$ & $\ldots$ & $\ldots$ & 844 \\
\hline & $\ldots$ & .. 3506 & & $\ldots$ & & ... 2183 \\
\hline & .. & ... 3 & & & & 351 \\
\hline & $\ldots$ & $\ldots:$ & $t \ldots$ & $\cdots$ & & \\
\hline & .. & & & & & \\
\hline & & 43 & & & & \\
\hline ronton .. & & ... 3111 & udgers Hall & & & \\
\hline
\end{tabular}




\begin{tabular}{|c|c|c|c|c|c|c|c|}
\hline Iyme Regis & 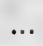 & .. & ... 2269 & Shoreham ... & $\cdots$ & $\ldots$ & ... 10:17 \\
\hline Lymington & & ... & ... 316-1 & Steyning ... & $\ldots$ & ... & ... 3424 \\
\hline Maldon .. & $\cdots$ & ... & .. 3198 & St. Gernuains & $\cdots$ & ... & 2.10 .4 \\
\hline Malmesbuary & $\ldots$ & ... & $\ldots 1976$ & St. Ives $\quad \ldots$ & ... & ... & ... 3526 \\
\hline Kalborough & $\ldots$ & $\cdots$ & ... 1338 & St. Mawes ... & ... & $\ldots$ & ... 164 \\
\hline fidhurst ... & $\ldots$ & ... & $\ldots 1335$ & St. Miehael's & $\ldots$ & $\ldots$ & ... 20 \\
\hline e Port & $\cdots$ & $\ldots$ & $\ldots 1410$ & Stockbridgo & ... & ... & 71 \\
\hline Jewp & ... & ... & $\ldots 977$ & Thetford ... & ... & ... & ... 2922 \\
\hline pton & $\ldots$ & $\ldots$ & ... 2023 & Thirsk & $\cdots$ & $\ldots$ & 3502 \\
\hline$\ldots$ & $\ldots$ & $\ldots$ & $\ldots 1119$ & Tiverton & ... & ... & ... 1500 \\
\hline ield... & ... & $\ldots$ & $\ldots 1152$ & Totness & $\ldots$ & $\ldots$ & ... 1035 \\
\hline$\ldots$ & ... & ... & .. 2933 & Tregony & ... & $\cdots$ & ... 2712 \\
\hline ton ... & $\ldots$ & $\cdots$ & $\ldots 762$ & Truro $\quad \ldots$ & ... & $\ldots$ & ... 2712 \\
\hline oury & ... & $\cdots$ & ... 881 & Wallingford & ... & ... & 2093 \\
\hline Ret & $\ldots$ & $\cdots$ & $\ldots 2465$ & Wareham ... & $\cdots$ & $\cdots$ & ... 1931 \\
\hline ond... & ... & ... & $\ldots 3516$ & Wendorer... & ... & ... & ... 1602 \\
\hline Romney ... & ... & $\ldots$ & $\ldots 962$ & Wenloek ... & $\ldots$ & $\ldots$ & ... 2200 \\
\hline Rye $\ldots$ & ... & ... & .. 3599 & Weobly ... & ... & ... & 739 \\
\hline Ryegato & $\ldots$ & $\ldots$ & ... 2961 & Whitchurch & $\ldots$ & $\ldots$ & 1434 \\
\hline Saltash $\quad .$. & ... & ... & $\ldots 1518$ & Wilton $\quad \ldots$ & ... & ... & ... 2058 \\
\hline Sandwich ... & ... & $\ldots$ & .. 2912 & Winehelsea & $\therefore$ & $\ldots$ & $\ldots 819$ \\
\hline Sarum, Old & $\ldots$ & $\cdots$ & $\begin{array}{ll}\ldots & 0\end{array}$ & Woodstock & $\ldots$ & ... & $\ldots 1455$ \\
\hline & $\ldots$ & ... & .. 1047 & Wootten Bass & & ... & ... 170 \\
\hline Shaftesbury & & & ... 2903 & T & & & $\cdots$ \\
\hline
\end{tabular}

Each of these miserable villages sending two members of parliament, while Manchester, with a population greater than that of the whole put together, did not send one, and whilc Bolton, Bury, Rochdale, Oldham, Ashton, and Stockport did not send one, was it wonderful that there should be deep discontent? Was it not more wonderful that thero should be any tranquillity-any submission? The publication of this list, over and over again, in every possiblo shape, and year after year, did some good. Was there a single instance of disregard of public opinion, out eame the list to show that the people were not represented. Was there a single instanee of class legislation, out oame the list to show that nothing better was to be expected. Men committed it to memory, and taught from it as from a text. There was nothing new in it; anybody could have complied 
it; anybody could have contrasted Old Sarum with Manchester. But the fiet that one hundred boroughs sent two hundred members, the whole of those places not contnining so many inluabitants as the single unrepresented parish of Manchester, sunk into men's minds, and prepared them for the subsequent contest. $\Lambda$ article from my paper of the 15 th of July, printed in small type, on the "Causes and Cure of the Present Distress," was sold in thousands, and earried instruetion to tens of thousands, who seldom had a chanee of seeing a sermpenny newspaper.

In August it was determined to hold a meeting, at which public opinion might be expressed upon the state of the country. A short time previously the boroughreeve and constables hat refised to call a meeting to take the question of slavery into consideration; and it was resolved that applieation should not be made in this instance to those petty officers of the lord of the manor. The requisition to eall a publie meeting was, therefore, addressed to the ehurehwarlens, who, being elected by the ratepayers, might be supposed willing to allow their eonstituents to be heard. Those gentlemen refused. This conduet, on the part of these two sets of public officers, did much to create the desire for the ineorporation of the borough, which was afterwards effected. The meeting, however, was ealled, on the requisition of the following gentlenen:-

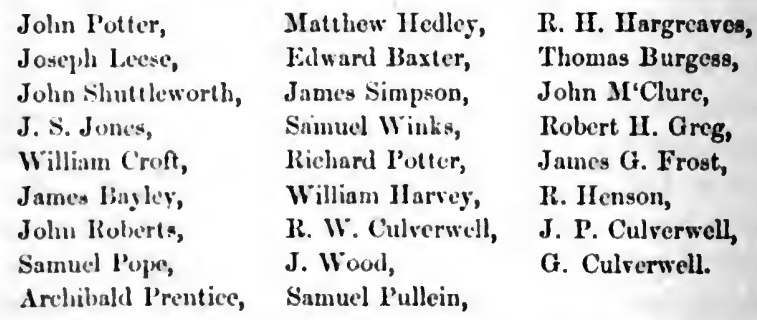

It will be seen by those who recollect the names of gentlemen then known as usually taking a part in public business, that they were $\mathrm{few}$ on the above list of the 
persons who were usually designated as "constitutional whigs." They held aloof, and represented the morement as being likely to endanger the publie peace. 'The neeting was held on the 19th, in the Manor Court Room, which was erowded to exeess Mr. Edward Baxter in the chair. The first resolution, declaratory of the general distress, was proposed by Mr. Richard Potter, who drew a pieture of the wretchedness of the working people, which was listened to with expressions of the deepest sympathy. The motion was sceonded by Mr. Inivid Ilolt. The sceond resolution, declaratory of the mischierous operations of the corn laws, was proposed by Mr. John Shuttleworth, who ably eombatted the argument of the agriculturists, that they were entitled to protection because they had to bear the "peculiar burthens" on land; he disclaimed all protection to home manufactures as more mischicrous than bencficial; he demanded a recurrence to sound principles in the trade in eorn as essential to the preservation of our commeree; and strongly urgerl the necessity and the duty of a strong protest against laws which were ruinous to oursclyes, and likely to shake with foreign states those relations of peace and friendship which shed blessings on all; and for the contimunee of which a free trade in corn would be an additional, probably the most powerful, sceurity. The seconder of the resolution was Mr. Mark Philips, afterwards member for the borough, who, it was understood, appeared at the meeting much agitinst the wishes of some of his whig friends, but who saw, in the stern necessities of the times, a strong reason for entering his carnest protest against the imporerishing corn laws. At the conclusion of his short but energetie speech, which, from a young man making his first appearance, the son of an old and firm friend of reform, was reccived with great applause, he modestly apologised for addressing the meeting, but said that at a time when tens of thousands were suffering the deepest distress, it was an imperative duty to stand forward 
and deelare the wreteliedness which had been oecasioned by bad legislation. The third resolntion, declaratory of the excessive pressure of taxation, was proposed by myself. I asked if there was anything in the circumstances of the country that wonld justify an expenditure fourteen times greater than it was in the reign of George the First? Coming to a later period, a period subsequent to that war against our colonies, in which we expended a sum the mere interest on which was larger than the revenue of the new and prosperous republic that had achieved its independence; eren with the interest on the debt, the expenditure in 1792 was not more than one-fourth of its amount in 1826, after eleven years of peaec. It appeared that the machinery of the state was the only machinery that had not received sinplifieation and improvenent, and that while art and science had combined to lower the cost of everything else, the cost of government had daily become greater and greiter. Mr. Croft, in seconcling the motion, said that ministers, in reducing the duties on silk while they resisted the repal of the corn-laws, had "acted with grcat inconsistency and great injustice. The other resolutions were proposed or seconded by Messrs. William IIurvey, Thomas Burgess, lBenjamin Ilolbrooke, Iriclding, and Pullein.

The Ginarlliun newspaper had done what it could to prevent this meeting being heid. Its proprictor had refused to sign the requisition, on the ground, as he afterwards alleged, that some proposal would cmanate from it for breaking faith with the public crelitor! After it had taken place, for weeks together, he continued to contend that the amount of taxation, per head of the population, as stated by me, was less than it had been in 1811, leaving entirely out of view the great increase in the value of money, oceasioned by the resumption of cash payments. He had, in the previous year, purchased the copyright of Harrop's British Voluntecr, incorporated that paper with the Guardian, and had thus added a thousand tory readers 
to his former subseription list. IIe was thus cnabled to announce that his circulation was double that of any other Manchester paper, and this oceasioned a great influx of advertiscunents, and made him entirely "independent" of the whig-radicals who had furnished him with the means of establishing his newspaper. This "independenee" he now manifested in declining the request of Mr. Baxter, a gentleman who had been most active in getting up the subscription to establish the Guarclian, to allow the petition to the king to lie at his office for signature. The example of Manchester, however, was followed by many of the large towns, and ministers, yielding to the ontery against the corn-laws, exereised the diseretionary powers vested in them by parliament, by admitting eertain kinds ' of grain and pulse to be taken for consumption at a small duty. The distress, however, continued, in great intensity, and parliament showing no disposition to adopt any permanent measures of relief, inen's minds were strongly direeted to the constitution of the house which professed to represent the people. In an article on the state of the country, in my paper of the 2nd of December, I said :-

"We suspect that the time is not far distant when the peoplo of this country will be eonvinced by painful experienee, that n jealous watelifulness of the measures of government, and a firm determination to oppose, by every eonstitutional means, the existenee of gross abuses in the machinery of the stute, and the erention of oppressive and imporerisling laws, are ns necessary, in order to preserve tho prosperity of the nation, and, indeed, its rery existence, ns n commereial country, as industry and caution are to the suecess of individuals. How often lanve we licard the senseless ery of ' mind your own business, and let politice alone,' whenever n elear-headed mnn endearoured to ronse the public to a sense of their dinger. However, the timo is not far distnut, when every ono will finl that politics suss be studied, nud when the legislature sust be toll, in firm, and manly, and most deeided terme, that a olEAT reFons is absolutely necessary in order to reseuo the country from a ruin which is not the less certain because its approaches are slow and ginilual. This time is eoming. People begin to learn in the dear school of experience that a law whieh prevents our obtaining the necessaries of 
life from other nations, and at the same time deprives them of the power of purchasing our manufactures, is really adverse to our commercial prosperity. Hence the unirersal opinion, in this part of the country, that an alteration of the cons-LAws is neeessary for the very existence of our trade, and the consequent loud call for their repeal or modification. These enlls will be followed by others, still more loud and importunate, for a GREAT BEDOCTION on rsxatios, for it must become daily more obrious, that the only argument for the permission of the corn monopoly is, that the owners of the soil need high prices, to enable them to pay high tares; and, as those calls will not be listened to, or if heard, will be, by such miscrable soplistry as Mr. Canning, with so little regard to his reputation, had recourse to the other evening, in order to show that the erection of splendid palaces was, in reality, a means of lessening the sufferings of the people; - as such calls will bo answered by such insults to common sense, the people will in time acknowledge that it would have been well had they earlicr inquired into the state of the representation; and, being at length eonvinced that it was an essential part of their 'business' to take eare that tho public purse shall be entrusted to honest guardians, they will then demand a THonocou nefors of the representative system. "To this complexion we must come at last ;' ond it is a moral cowardico in those who are couvinced of the necessity of parliamentary reform, to aroid the mention of the great cause of the erils against which they remonstrate. At a meeting of the meinbers of the Chamber of Connerce, it was resolved to petition ngainst the Cons-Laws; but no notice was taken of the doubly oppressivo load of taxation. At the meeting of the ratepayers, in A ugust last-a meeting which, whaterer the editor of the Guardian, and a few timid, self-styled whigs, might think of it, was one of the most important that crer was held in Mancliester, and one whose resolutions excited more attention thoroughout the nation than any which preceled them,- - at that great meeting it was resolved to petition for a repeal of the corn-lawe, and a great reduction of taxation, but no notice was taken of the state of that house which sanctioned the imposition of the grierous public hurthens under which we groan, and, for the interests of its own members, passed the law which is so midly destroying our trado and manufactures. Another meeting is tnlked of, ond we trust that in remonotrating against the continuance of oppressirc burthens, the oystem under which they hare been impoacd will not escape the animadversion of our public-spirited townmen, and that their petitions will

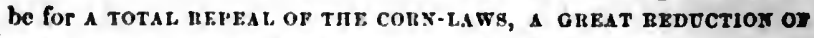
TAXATION, AND PARLIAMENTARY REFORY." 
Six years were still to clapse before any portion of parliamentary reform was obtained; twenty-three years before foreign corn was to be admitted free of duty. If men were to foresee all the difficulties to be overcome in effecting public good, little would be attempted. In after times, when I was asked how soon the abolition of the corn laws would be effected, my reply usually was: "No man can speak with eertainty as to the time: one thing we are sure of-it will never come unless we ask for it. It is our business and our duty to forward the time as much as we can."

In the year 1826, in which the deep distress of the poor and the timely bencrolence of the wealthier classes were alike memorable, a soeiety was established, having for its object the preservation of a right of considerable importance to the former. The volumes of smoke which, in spite of legislation to the contrary, continually issue from factory chimneys, and form a complete cloud over Manchester, certainly make it less desirable as a place of residence than it is as a place of business; and the enjoyment of the inhabitants would be greatly increased, could they breathe a purer atmosphere, and have a brighter and more frequent sight of the sun. But, to counterbalance the disadvantage, they have the privilege of walking umestrainedly through the fine fields of the vicinity; and thousands and tens of thousands, whose arocations render fresh air and exercise an absolute necessity of life, avail themselves of the right of footway through the meadows, and corn-fields, and parks in the immediate neighbourhood. There are so many pleasant footpaths, that a pedestrian might walk completely round the town in a eircle, which would seldom exceed a radius of two miles from the Fxchange, and in which he would scarcely ever have occasion to encounter the noise, bustle, and dust of a public eart road or pared street. The beautifully undulating country between the valley of the Irk and Chcetham IIill ; the fine ralley of the Irwell, with its verdant meadows; the slope from Pendleton to the plain, 
which, commencing between the extremities of Hulme and Chorlton-upon-Medloek, extends south and west over the greater part of Cheshire; all this seenery, which in any country would be admirel, but which has a hundred additional charms to him who is condemned, day after day, month after month, and year after year, to toil in the dirt and smoke of a great town-all this delightful scenery lies open to the pedestrian; and while he strays along through the open field, or wooded park, or the narrow and retired lane, and breathes the pure air of heaven, he feels that all these fields, and parks, and lanes, are as open to him, and to those who hang on his arm, or play by his side, as if they were his own, to have and to hold, as long as trees grow or water runs.

But there are "tyrants of the field"-men who imagine that that which runs through theirs must needs be theirs; and they must be withstood. About some twenty years before the period of which we write, a Mr. Ralph Wright, of Flixton, a parish a few miles south-west of Manchester, possessed an estate partly purchased and partly inherited, which had the usual complement of hedges, along which ran certain footways, and by which they were concealed from his house. Being desirous of giving to his property, which did not consist of more than fifteen or sixteen acres of land, a more park-like appearance, he levelled the hedges and fences; and finding that this brought the footways more in sight of his mansion, he began to use means to prevent the vulgar part of his neighbours eoming between the wind and his nobility. One way, which went right across his little park, he shut up altogether, without the formality of any magistrate's order. Another, which formed part of a church road for several farm-houses, lie diverted to a distance considerably farther from his house. To these encroachments his neighbours, unwilling to be thought quarrelsome, peaceably submitted; but another effort met with determined resistance: this was to divert the roads 
to beyond the boundary of his own grounds, so that his property might not be traversed at all. He was a magistrate, and he obtained orders signed by two brother magistrates; but, without waiting for the confirmation of the orders at next quarter sessions, he stopped up the entrance to his grounds, ploughed up the old footway, and sowed the land with oats. Mr. Samuel Wood, a farmer in the parish, like the spirited old shoemaker of Bushy Park memory, was uawilling to leave the world worse than he found it, and, assisted by his neighbours, broke down three several times the obstructions that had been put up, and restored the original road to the publie by treading down the oats.

The magistrate proceeded hesitatingly. In 1824 he obtained another order: this was appealed against; but when the applicants were ready with their witnesses it was abandoned. Another order immediately followed, but it was quashed on a point of form. A third order was more successful, being confirmed at the spring quarter sessions. All this was attended with expenses which were too heavy to be borne by a few persons of the class of country farmers. Thomas and Richard Potter had aicled; but it was desirable that some association should be formed for the purpose of preventing this and similar encroachments, and removing from individuals the persecution to which they might be exposed in resisting the encroaching spirit of powerful country gentlemen. A meeting was accordingly held in the Town Hall, November the 15th, 1826, at which was formed a Society for the Preserration of Aneient Footpaths, and the following gentlemen were appointed a committee to carry its objects into effect:-

Joseph Armstrong, Edward Baxter, Thomas Heywood, Thomas Hilton, Edward J. Lloyd, Robert Millington, Archibald Prentice, Joln Edward Taylor, J. B. Wanklyn, George Wm. Wood,
Robert IIyde Greg, John Kenworthy, Richard Potter, Robert Tebbutt.

A pleasant association this of tories, whigs, and radicals, 
and one which, in the successful results of its resistance in many attempted cases of encroachnent, spread amongst the country gentlemen a wholesome terror of transgressing against the right of the poor to enjoy their own, without any one to make them afraid.

The Flixton people, having now the sanction and countenance of men holding at least as good a station in society as Ralph Wright, Esq., resolved to make another effort for the recorery of their right of road. They sued out. a certiorari and remored the ease into the Court of King's Bench, and after many motions and counter-motions, the order of the sages of the quarter sessions for confirming the order to stop up the footways coreted by their brotherhood of the bench, was quashed; and on Monday, the 14th of June, 1827, several respeetable inhabitants of Flixton, accompanied by some of the Manchester society, who were desirous of witnessing the renewal of a privilege of which the public had heen for two years deprived, went in procession to open the roads, and the application of a saw gave them ingress to Mr. Wright's "park." The ground was covered with a very fine crop of grass, nearly ready to be eut; and the path, consequently, was not very obvious, but here and there it was indicated by the growth being shorter, and it was easily traced. The party having crossed the park, eut down the fences on the other side, and having thus asserted their and the public right, retired peaceably. I happened to arrive a minute or two after the procession had crossed the park, but, though I missed the satisfaction of seeing the unlawful impediments cut down, I experienced a higher pleasure in olserving the fresh marks of the saw, the little two-feet wide opening. and the newly-made track through the tall grass, than such sights might be thought capable of giving. They spoke the triumph of an ancient law over the grasping and monopolising spirit of modern times. When I reached the middle of the large field which, by the destruction of two or three hedges, had been raised 
- into the dignity of a "park," I could not help being struck with the bad-taste, to speak of it in the gentlest terms, which sought a solitary greatness by the exelusion of every mark of rustic neighbourhood.

These contests cost the appellants nearly $\mathbf{f 6 0 0}$, and, as they must have been equally expensive to Mr. Ralph Wright, it might have heen supposed that he would desist from any further attempt at eneroachment. But the magistrate was bent upon his purpose, and on the 14th September four orders were signed by Robert Fielden and James Brierley, Esqrs., for stopping up these paths. 'The persecuted inhabitants of Flixton entered another appeal. It was tried at the quarter session, on Monday, Oetober 29th, lasting nearly all day, and ending in the final diseomfiture of MLr. Wright, but at a cost of $\mathbf{f} 750$ to the spirited vindicators of a public privilege.

I may have oecasion again to mention other contests for right of road. In the meantime I may refer to one where the opposition to encroachment arose directly from the result of the Flixton case. About a mile from Bromsgrove resided a Dr. Collett, near whose house a footpath crossed between two parallel roads. About the year 1814, he, without any magistrate's order, diverted this cross pathway to a greater distanee from his house, and formed a paddock on the site of the old pathway. Dr. Collett, having thus driven the public to some distance from him, now wished to drive them out of sight altogether. Mr. Wright wanted to have his "lawn" to hiniself, free from publie gaze; and Dr. Collett wanted to have his "lawn" in exelusive sight as well as exclusive oceupation. Ife found two elerical magistrates ready to forward his wishes-the Right Hon. and Rev. Walter IIutehinson, Lord Aston, and the Rer. William Vernon, who, on the 6th of June, 1827, signed an order to shut up the road as " useless and unnecessary." An appeal was marle to the Worcestershire midsunmer sessions, but the magistrates confirmed the order of their 
elereial brethren. Mr. Eilins, one of the appellante, was not disposed to allow a publie right to be lost. He had heard of the Flixton ease, which mueh resembled his own; he visited Manchester; consulted Mr. Richard Potter; had Mr. Charles Wood, solicitor to the Footpaths' Protection Society, back with hin to Worcestershire; and on the 20th of May, 1828, a motion in the Court of King's Bench, for quashing the order, eame on to be heard. The order was quashed, on the grouud that the reverend magistrates who signed it did not state, as the aet required, that it having been on " view" found to be useless, it should be stopped, but "as it appeared" to them. The fact was, that they could not have viewed the road. The road ordered to be stopped was not the diverted but the old road, and to view it they must have broken through a garden wall, and cut through a plintition which had existed for fourteen years. At the opening of the roal, on the 26th of May, a portion of the wall was razed to the ground, part of a greenhouse was destroyed. several of the trees in the plantation were eut down to the ground, and, as at Flixton, a procession was formed of pullic-spirited individuals, who exercised the reseued right. and rejoiced in the triumph of the law over the grapping designs of another "little tyrant of the field."

In the begimning oi 1827, Mr. Thomas Burgess, one of the members of the "Footpaths' Protection Society," called my attention to another attempted encroachment, and I find the following notice of it in my Gazette of the 17th of February :- " Every inhabitant of Manchester must have observerl, with some degree of pride, the wide and noble approach to the town from the Liverpool and great north road, and they will learn, with feclings of indignation, that the space between the houses and what is strietly the public road, from the Crescent to l'endleton P'ole, has been, or is to be, leased by the chancellor of the duchy to an individual who will have it in his power to ereet cottages in front of the elegant mansions whieh have been built in the faith 
that his majesty, the Duke of Lancaster, would never permit that noble approach to be encroached upon. When so much has been expended in the purchase of old buildings to widen one short street in Manchester, we cannot mention, with any tolerable degree of patience, this permission to cover with buildings one of the finest outlets from this great town. We really think the officers of the duchy could not have devised any means more likely to make the chancellor unpopular; and it is astonishing to us, that any inhabitant of the township could be tempted, by any prospect of profit, to make a bargain which he must have known would be a most odious one in the eyes of his fellow townsmen. A meeting has been held at Pendleton, at which Mr. Burgess brought forward a draft to the chancellor on the subject, and at which Mr. G. Jones acknowledged, or rather avowed, that the lease conferring on him such odious powers was already granted. We trust, however, that the chancellor has it still in his power to arrest measures which, we are confident, our gracious sovereign, the Duke of Laneaster, would be sorry to permit against the wishes of the inhabitants of this, the second town in his kingdom." In addition to the Pendleton memorial, one was sent from the police commissioners of Salford, and the result was, that Lord Bexley, the chancellor of the duchy, refused to complete an arrangement into which he had been led by false representations of the nature of the property. 


\section{CIIAPTER XIX.}

CANNING's CORY LAW.

TIE necessity for a temporary suspension of the prohibitory corn law of 1815 had led to the belief that a ministry, of which Mr. Canning and Mr. Ifuskisson, both professed free traders, were members, would frame a less restrictive measure, and the fears of the landlord class were greatly exeited. Before the opening of the parliamentary session in 1827, petitions from the agricultural distriets were manufactured with untiring assiduity, and eagerly signed by frightened farmers, who laad been persuaded that, instead of any relaxition of the monopoly, a positive exclusion of all foreign corn was searcely protection enough. The outery was so loud as to make the opponents of the corn law believe that some really important reform was coming. They could not suppose that all this hubbub was for nothing, and the manufacturing distriets, seeking, besides, a breathing time nfter the harrassments of 1826 , remained perfeetly quiescent. Here and there, indeed, the public voice against the corn monopoly found feetle utterance; here and there were a few radicals who thought and said that a bitter enemy to fair und free representation could not be the honest friend of free trade; but our manufacturers remained in the quiet and undisturbed relianee that ministers would follow the course which humanity and policy dictated. The measure, so mueh dreaded by the landowners, und anticipated by the manufaeturers with so much reliance on ministerial honesty and wisdom, was framed on the assumption that when wheat was at 60 s. a

- quarter, the home grower should receive a protection to the amount of 20s. The professed free traders, Canning and 
Huskisson, proceeding on this assumption, fixed 60s. as their pivot, increasing their duty as prices diminished; so that when wheat was at 50s. the duty should be $40 \mathrm{~s}$., but diminishing it as prices advanced, so that at $70 \mathrm{~s}$. wheat should come in free. With what reason the corn growers might congratulate themselves on their clamorous activity, and the corn consumers might bitterly lament their supineness, under an ill-founded reliance that ministers would do that which they did not think it worth their while to ask them to do,-with what reason the one class might exult and the other night mourn, may be judged by the fact that, immediately on the publication of Mr. Canning's longpromised and anxiously-looked-for resolutions, wheat experienced an advance of $5 \mathrm{~s}$. a quarter. The bitterness of my own feelings, on seeing the result of a blind reliance on ministerial honesty, found vent in the following remarks :-

"On the back of proposals for such an alteration of the laws as would give relief to the corn consumer, we have the records of every market in the kingdom announcing an adrance of prices, and becoming so many libels upon the proposers of this seheme, and proclaiming to a half-bankrupt and half-starved people, that their reliance on ministerial firmness was miserably misplaced. What a commentary on Mr. Canning's raunted no-drought and no-deluge scheme do the reports of the corn markets furnish. 'A greater degree of liveliness,' say the market historians, 'was experienced to-day, in consequence of the prices at which grain may be imported being fired higher than was expected. Wheat rose five shillings a quarter, and a further improrement may be expected.' Well, indeed, might they anticipate an inprorement, when they knew that, according to the now corn law seheme, wheat could not be imported without the payment of a daty of thirty-four shillings a quarter-a duty which would make the English consumer pay a slilling for every sixpence-worth of foreign flour.

"While we are compelled to say that ministers have miserably disappointed the hopes which were founded on their own deelarations, we must add that the people in the manufacturing districts are not without blame. They knew not only that they were without representatives in parliament, but that it was constituted almost entirely of those who had an interest in preserving the corn monopoly un- 
broken. They knew that ministers had no influence to oppose to that of the lund-owners but what was derived from public opinion. Yet, knowing this, - knowing that an almost overwhelming force waa to be contended with, they permitted week after week, and month after month to slip awny, without giving ministers the aid of their unequirocally deelared opinions, and thus left them no alternative but to yield to the stronger power, or relinquish their places. This supineness is the more to be regretted, when we consider that it was not the result of indiflerence as to the decision of the momentous question whether fool wins to be dear or chenp. There was but one opinion prerailing, and that was, thint our very existence as a manufacturing and commereinl uation depented upon our being placed on something like an equality with other nations with regard to the necessaries of life. This was the opinion, but unfortunately it did not recire the public expression which it onght to have receired, and though men's hearts burned within them when they thought the people were starring while there was abundanee of food upon tho earth, a full public utterance was not giren to their opinions and feelings.

"In endeavouring to account for this indifferenco as to the public expression of what every man felt, we are led to think that it might be occasioned by too great a reliance on the public journals. The tory press, whaterer it might say concerning the corn laws, has always discountenanced public meetings; and, unfortunately, tory ism in the press has no better opponent than it has in parliament. Your whig editor is like your whig member, a ereature of mere shifts and expedients; and while he can suggest somo palliative, will not recommend an effectual remedy, and will even then throw obstacles in its way. That we do not unfairly characterise the public press will be confessed, when it is reeollected that the most unequivocal expression of public opinion which was ever made in Manchester was effected by this paper, not mercly unaided, but opposed by all its contemporaries.

"When a blunder las been committed, no time ought to be lost in rectifying it. The landed interest has been permitted to get beforo the manufaeturing interest in their representations in parliament; but the rezolutions so farourable to them, and so obnoxious to us, are not yet become a part of the laws; and a strong expression of the opinion which prevails in the manufacturing districts might even yet be effectual in procuring the modifications which justice and policy demand."

The strong expression of opinion thus earnestly called for was not made. The bill was passed in the Commons by 
a large majority ; but in the Lords the Duke of Wellington, after a elever manceurre, by which he entrapped the simple Mr. Huskisson to a seeming approval of his movement, succeeded in earrying an amendinent which went, in effect, to the destruction of the measure as one of comparative relief from the acts of 1815 and 1822, which had been almost entirely prohibitory. Ministers conld not, with any show of decency, press their measure any further, and it was accordingly withdrawn, to be followed by one on the following year, framed in accordance with the Duke's opinions as to the amount of protection. Probably the adroit diplomacy by which poor Huskisson was made to appear as giving his sanction to an amendment which destroyed his and Canning's bill, may have suggested to Wellington that he, the F. M., was not destitute of the kind of knowledge which fits a man for the offiec of prime minister, when a peeuliar kind of left-handed wisdom is more required than statesmanship.

While lords and commons, whigs and tories, seemed to think or to act upon the opinion, whether they believed it to be true or false, that to prevent the price of corn from falling too low was a very proper object of legislation, it was edifying to read their replies to the starving workmen who prayed that something should be done to prevent wages from falling too low. The Bolton weavers petitioned that a power should be given to boards of trade, consisting of the most extensive manufacturers in each district, to regulate the prices of weaving; but, in reply to this application, they were told that it would be very improper in the legislature to interfere in contracts between the workman and his employer. It was quite necessary and proper, said our law-makers, to regulate the price of corn, but to attempt to regulate the price of labour would be at varianee with every principle of sound political economy. There was no disinclination to teach sound principles when practice upon such principles took nothing out of their pockets. 
Mr. Canning's clevation, in the summer of 1827 , to the position of prime minister, gave satisfaction to veither of the extreme parties in Manchester. The tories hated him for his approaches towarts liberalism; the radicals distrusted hin because he was still an obstructive. The friends of "protestant aseendancy" regarded him with a bitter scowl beeause he purposed to remove the disabilitics under which the catholies suffered; the friends of religious liberty gave him no eredit for sineerity, for he was still opposed to the repeal of the test and eorporation acts. The firourers of continental absoluteism looked with alarm to acts tending to withdraw England from the influence of the " holy alliance;" but reformers were told, and with a fiereely defiant air, that, though he would not suceumb to despotical dietation abroad, he would strenuously support the nnmitigated rule of the aristocracy and the boroughmongers at home. The landowners raised a furious outery against his modified support of free-trade doctrines; a considerable part of the manuficturers, and almost all their workmen, looked on his eorn bill as a proof that he was a determined supporter of the corn growers' monopoly. And yet this was a great ern-a pirot period on which the progressive and the stand-still policy stool vibrating, few knowing in what direction the turn might be made. The middle elass reformers, with whom I acted, were hopeful that some suceessful innovation might be made on traditional usages of government, and I believe that I expressed their opinions when I said our hope arose from the belief that a government constituted like that of Mr. Canning would be influenced by public opinion, when that was unequivocally and boldly cxpressed, und that any movement it might make in advance would encourage the people to bolder demands; and that thus the reciprocal action of government upon the people, and of the people upon the goverment, would lead to the recognition of prineiples from which almost all classes of men in parliament had hitherto recoiled. 
When the suceess of the Duke of Wellington's amendment in the Lords threatened to be fatal to the proposed "amendment" of the corn law, and to throw the country back upon it in its unmitigated rigour, the Manchester Chamber of Commerce made a languid movement; that chamber, then behind public opinion, and continuing behind it until December, 1838, when it aroused itself, after a long sleep, met on the 27 th of June. Mr. Hugh IIornby Birley in the chair. Mr. George William Wood, sceonded by Mr. Shakspeare Plillips, moved, "That the chamber was of opinion that though the bill proposed a scale of proteeting duties higher than sound policy suggested, and the welfare of the general interests of the country required, it was, nevertheless, founded upon just and salutary prineiples, and would tend to mitigate the evils of the existing corn laws." I could not recognise, as a just and salutary prineiple, the imposition of a forty-shilling tax on the importation of wheat when its price was fifty, and I moved an amendment that the words should be "more just and salutary than the existing law." There were 15 rotes for my amendment, and 16 against it. Had I imagined that opinion was so nearly balanced I should have taken more pains than I did, but I committed the mistake of believing that the chamber was too conservative to allow a free-trade to earry any resolution. When the petition, founded on the resolutions, was read, I moved again that the qualifying comparison should be used, and was supported by Mr. Robert Garnett, who had previously roted against me. I now thought that there would be a majority of one in my favour, but Mr. John Edward Taylor, of the Guardian, who had voted for me, turned round and voted against me, on the ground that the resolution and the prayer of the petition ought to agree. The closeness of these divisions betokened a change in the opinions of that very timid association, although many years elapsed before Cobden, Bright, Smith, Ashworth, Bazley, and others of 
progressire movement principles, took the place of men who would put forth all their encrgy to have a quarter of an hour's earlier delivery of letters, but who would not put out their little finger to lighten the heavy burthens imposed by selfish legislation.

A public meeting was held in the Town Hall, on the 5th of July, at which Mr. G. W. Wood made a good speech against the existing law, but confessed he would hare been almost satisfied had Mr. Canning's bill been passed. Mr. John Shuttleworth did not so much approve of that measure as to be much mortified by its defeat. "The fate," he said, "which has attended the project, such as it is, shows, more decidedly than the loss of a stronger and better measure would, the necessity there is for increasing the influence and power of those who, with good intention have used it, by every demonstration of popular support." Mr. J. C. Iyer wished to see the population of his country, not as half-starved paupers, but as well-clothed, well-fed, and eontented artizans; and if they were permitted freely to import cheap food, he was confident that this would bo their state, and that their prosperity would go on increasing and bid defiance to the competition of the world. Mr. Richard Potter made an effective speech on the occasion, and, in allusion to a phrase used in the House of Lords, he said, "Lord Grey, and I regret, and you must all regret that such language should have been used by sueh a man, has hinted that a repetition of language calculated to bring the 'order' to which he belongs into contempt or disrepute; might subject the parties to banishment, but such a threat will be treated by the country with the contempt which it deserves. If, however, his lordship and the 'order,' by which he says he will stand or fall, should proceed to extremitics, I trust, nay, I am sure, there will be men found in the country, yes, in this room, ready to stand up for the rights of the people." Mr. Robert Hyde Greg ably exposed the fallacies by which the members of the landed aristocracy 
attempted to defend their monopoly, and said that the lords, whenever the question of the corn laws eame before them, seemed suddenly deprired of eommon sense, common policy, common honesty, common decorum, and common humanity. Mr. Greg coneluded by quoting the lines written by Lord Byron, so often afterwards used during the anti-corn-law agitation, and so much to the annoyanee of the landed interest :-

"And will they not repay the treasures lent?

No! Down with everything and up with rent!

Their good, ill, healtb, wealth, joy, and discontent,

- Aim, being, and religion,-rent, rent, rent!!"

The resolutions passed at this public meeting did not, like those of the Chamber of Commerce, recognise, as just and salutary, the principle of Mr. Canning's bill, but they did not denounce, but rather approved, the principle of a moderate fixed duty, and I belicve the free-traders of that day would hare considered the imposition of an eightshilling fixed duty as a fuir compromise between the agricultural and the commereial interests. But Mr. Canning, bitterly as he was denouneed as an enemy to the protection of agriculture, had neither the wish nor the power to effect so great a change, and was now rapidly approaching the time when he was to find refuge in the grave from the hatred of an aristoeraey whose fears he had alarmed and whose hatred he had incurred, withont gaining any confidence and sympathy from the multitude, whose miseries he had mocked and whose claims for justice he had insultingly derided.

Amusing instances-if bitter rancour can erer amuseof intolerant feeling oceurred at all the Pitt dinners of this "pivot" period. At one of their celebrntions, held at Warrington, the chairman, the Rev. Peter Leigh, said that Mr. Canning was one of the greatest political swindlers of the day, and one who would take advice from erery dirty radical, insane theorist, and mongrel whig; that he was a 
political Judas, who would prove the greatest curse that ever had afflicted any country; that if ever there was a name in England that deserved public execration, it was that of George Camning ; and that he hoped the king would spurn from his councils that despicable truckler-that political profligate-and that I'itt's principles might again rule the British cabinet. The reverend orator concluded by calling upon his elerical friends present " not to cut the faggots on which they themselses and their church stood a tolerable chance of being devilled." All this abuse was lavished because Camning was in favour of Catholie Fimancipation. His determined support of the Test and Corporation Act, and his intolerance towards dissent gained him no farour in the eyes of those whose protestantism consisted in protesting against any invasion of their sineeures and plunalities. Wellington and Peel, in their eyes, were the never-to-yield champions of the protestant faith. In less than a year these same champions had repealed the Test and Corporation Act, and in less than another had granted Catholic limancipatation.

In this transitive period we were, for a brief time, allowed to entertain the hope that our great unrepresented town would have the privilege of sending two members to parlianent. One of the rotten boroughs had permitted its rottenness to be somewhat too openly exhibited, and so much virtuous indignation was expressed that it might have been supposed, by the uninitiated, that eorruption was only the exception and not the rule. Fortunately our expectations were disappointed-fortunately, becnuse, if ministers had possessed even the left-handed wisdom o cunning, they would have granted the Penyrn seats t Manchester one year, and linst letford seats to Birningham in another, and thus have spread over fifty years the demolition effected at once by the 1832 bill, and have gained for themselves the credit of being progressive reformers, slow but sure, occupying the just medium between 
the obstruetives and the destruetives, between finality and radicnlism. In $\Lambda$ pril, 1827, Penryn having been diseovered to be not immaeulate, Lord John Russell gave notice, that if it were disfranchised he would move that its seats should be transferred to Manchester, and Lord Stanley sent a communieation to that effect to the boroughreeve and constables, our then head municipal anthorities. This created considerable excitement, the tories and whigs agreeing in opinion that the commerce of Manehester would derive advantage from direct representation, and more decided reformers being eager that there should be some beginning, some starting point, to an amendment of that strange representative system which gave no member to Manchester and two to the little village of Newton, and two to some mounds of earth at Old Sarum. The reformers, seeing that the tories and whigs were disposed to move for this instalment of reform, resolved to let those two parties have the lead in managing the matter, and held back their own signatures to the requisition to eall a public meeting till the signatures of more cautious politieins were secured. I subjoin some of the names which appeared in the requisition-names which probably never afterwards were brought into such friendly contiguity of fellowship :-

John Barton,

R. W. Barton,

H. H. Birley,

Thomas Ashton,

Edmund Wright,

Jolın Kennedy,

James Burt,

B. H. Heywood,

Henry Newbery,

Benjumin Heywood,

G. R. Clappell,

Jameg Kershaw,

Alexander Káay,

Thomas l'otter,

Thomas Entwistle,
George Wm. Woorl, Shakspeare Phillips,

Robert Garnett, Joln Touchet,

William Garnett, F. J. Lloyd,

Jeremiah Fielding, Samuel Barton,

Thomas Hoyle, Edward Tootal,

T. IIarbottle,

R. H. Greg,

Daniel Grant,

Charles Cross,

F. A. Phillips,

James Wood,

W. Callender,

James Benrdoe,

William Inaynes,

Archibald Prontice,
II. Bannerman,

R. Cliristie, John Runcorn, Isaac Hately, Benjamin Braidley, Robert Stewart, Richard Potter, William IIarrey, J. E. Taylor, Edward Connell. 
The meeting, called by George Neden, boronghreeve, and Miehael Harbottle and David Bannerman, eonstables, was held in the unplastered large room of the Town Hall. The first resolution was proposed by Mr. H. H. Birley, the communder, in 1819, of the yeomanry corps which had eut down the people peaceably assembled to petition for reform. IIe sail he wished to see the manufacturing interests better represented. Mr. G. W. Wood, sceonding the motion, took nearly the same ground, and his complaint was not so much of the narrowness of the suffrage as of the exelusion of the manufacturing towns. Out of 658 members in the Iouse of Commons, he said, there were only nine connected with the manufacturing interest. Mr. William Garnett, in moving the second resolution, spoke only of the importance of the cotton trade, and then argued the necessity of its being represented. Mr. R. H. Greg, and Mr. Riehard Potter, both spoke very briefly, the understanding being that reformers should let the work be done by others not previously known as desiring progression. The resolutions were all passed unanimously; but a division arose upon the nomination of a committee, from which the names of persons supposed to be tainted with radicalism had been exeluded :-

"Mi. Thomas Hoyle proposed that the following gentlemen be appointed a committe to cmrry the resolutions into effect, viz., the boronghreeve and eonstables and durelswirdens of Manehester; Messrs. II. II. Birley, G. W. Wood, Shakspeare Philips, John Barton, Willam Gurnet, John Kennedy, 'Thomas Entwistle, R. H. Greg, Benjanin Heywoorl, G. Winter, John Kirkmn, Henry Newbery, Thomas Heywood, John Runcorn, Isaac Fuulkner, John Chippendall, William Cririe, and Thomas Worthington.-Mr. Prentice begged leave to say a few words before the resolution was put. He had been extremely ghad to observe the unanimity which had hitherto prevailed in the meeting, and it hal given him grent sntisfaction to sce the requisition signed by jurkons who, as Mr. Wood had remarked, werc of every gralle of political opinion. But he had no hesitation in saying, that the committe which land been proposed did not fairly represent the refuisitionists. (Hear, heur, hear.) In order, there- 
fore, that the committee, like the requisitionists, should eomprise persons of all political opinions, he proposed that the names of Mr. T. Harbottle, Mr. Edward Baxter, Mr. John Edward Taylor, Mr. John Shuttleworth, Mr. Richard Potter, and Mr. F. R. Atkinson, be added to the list which had been proposed by Mr. Hoyle. (The announcement of these mames was received with loud applause.)Mr. George Hadfield seconded the amendment. Ho said he was desirous that the conmittee should be composed of individuals of every opinion in politics, as it was desirable that all parties should be unanimous ; and he thought that unanimity would be best secured by the cordial co-operation of persons who represented the various opinions of the inhabitants. - Mrr. Camlelet proposed that Mr. Prentice's name should be added to the list.-The amended list, with this addition, was carried by a majority of ten to one."

The prayer of the petition was, "that whenerer cireumstances render it practicable, your honourable house, in conjunetion with the other branches of the legislature, will be pleased to extend representation to the town of Manchester, and such other townships of the parish as form, in fact, part of the town. Your petitioners, however, anxious that in their ease and by their successors, the elective privilege should be purely, independently, and constitutionally exercised, do further pray, that if it shall please your honourable house to accede to this urgent request, such regulations may be preseribed with respect to the mode of election, as shall effectually, and at all times prevent the tumult, delay, and expense by which elections for populous places are too often attended."

It will be seen that the petition bore no reference to the qualifieation of voters. It was thought desirable to do no more than to convinee the legislature that Manchester was willing to accept ropresentation, for even willingness to that extent was denied, by a member of parliament who rejoiced in the name of Mr. Lee Keck, A number of the gentlemen appointed on the committee were supposed to be favourable to the formation of a constituency of all who paid $£ 20$ a year and upwards, and there were not wanting plausible 
reasons, in the then state of representation, in farour of that qualification. In Glasyow, the fourth part of a member was elected by a corporation consisting of thirty coucillors, themselves self-eleeted. Compared with that mockery, a constitueney of 4,000 occupiers to the amount of f20 and upwards, would seem to offer some guarantee for an independent and judicious choice. East Retford was found to be not less eorrupt than Penryn; and Mary-lebone, Glasgow, Birmingham, and Leeds eame into competition for the seats. Glasgow seemed disposed to compromise for a member by offering to confine the roting to frecholders within the eity There seemed an excellent opportunity of selling seats to the large towns on the prineiple of the Dutch auction. But fortunately the spirit of obstruction to all reform was rampant, and the penny was clutchingly withheld to the loss of the pound.

On the 23rd of $\Lambda$ pril, in the following year, a meeting was held to pass the constables' accoumts, in which appeared the sum of $f 69$ as paid to a deputation from the Manchester committec to confer with Lord John Russell on the transfer of seats. On the motion that the accounts do pass; I moved, seconded by Mr. Candelet, that the accounts do pass, with the exception of 669 , on the ground that the deputation had assumed a power which had not been delegated to them when they bargained for an exclusive suffrage. I said that when Mr. Harbottle had proposed that a deputation should be sent to London, it was on the ground that an immediate representation should be made of the great importance of this town, and of the neessity of its interests being represented in parliament ; that this had not been done, but at a period long subsequent to that meeting. the committee had sent its deputation, not for the general objeet, but in order to traffic for a bill which denied to an inhalitant a vote unless he was assessed on a rent of

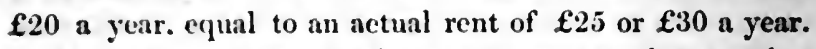
Could any one, I asked, who was present at that meeting 
ever have supposed that he was sanetioning that which would exclude so large a portion of the inhabitants, possessing a large amount of the intelligence and respectability of the town? Mr. Jeremiah Garnet attempted to get rid of the amendment, by saying that Mr. Prentice himself had been favourable to a $£ 20$ qualification, to which $m y$ reply was, that whatever my opinion might have been, it did not justify a bargain with parliament for the exclusion of so large a portion of $\mathrm{my}$ fellow-townsmen. The amendment was earried.

The bill for the disfranchisement of Penryn was ultimately lost in the House of Lords on June 23rd, 1828. The proceedings were thus bricfly reported in my newspaper of the time :-

"The Eurl of Carnarron moved the seeond reading of the Penryn Disfranchisement Bill. II lis lorlship proeeded to comment on the evidence at considerable length, and coneluded by stating that, in his opinion, it did not warrant him in moving that the franchise of the borough should be absolutely annihilated, by its transference to some other place, but it was sufficiently decided to make it imperatire on their lordships to adopt some course to prerent the recurrence of the bribery shown to have existed for so many years. - The Lord Chancellor (Lyndhurst) said, after attending duily to the evidenee, and after a subsequent perusal of it, he was satisfied that the further progress of the measure ought to be resisted. From the evilenee it appeared that there were 420 roters, and he defied the noble lord to show that bribery had been brought home to more than fourteen; and eren three of these instances depended upon admissions, and not actually upon testimony under the sanction of an onth. - Lord De Dunstanville remarkerl that it had been said, that as he possessed conisideruble property in the neighbourhood of Penryn, it would gire him a decided power in influencing the elections, should this bill pass. But he was convineed that the indeprendenee of the fredholders there, especiully of the substantial yeoman, was such that if all the men of rauk were to unite their influence in farour of one cancliclate, and a popular eandidate were to start, he would beat their united strength immediately. In his opinion no ease had been made out, either in law or equity, to justify the present bill.-The Earl of Fllow said he had never seen a casc so utterly destitute of foundution. - Lord 
Daere said he was no friend of theee wild doctrines of reform that would establish unirersal suffrage, or even householders' suffrage, in every case, for he did not think that any one uniform principle of roting could ever be adopted; but as the objeet of this bill was to transfer the franchise to the commercial from the landed interest, he shonld certainly oppose it.-The Marquis of Salisbury called the attention of their lordships to the worls of the preamble of the bill. They rail in this forn: "Whereas, on aceount of tho grent wealth and propulation of Manchester, it is expedient that it should return burgesses to parliament.' Now, in that single sentence were embodied all the wildest doctrines of reform. If there were no other grounds for opposition, he should oppose this bill on that ground alone. As no other noble lord had objected to the bill on that ground, he had determined to enter his protest ngainst such doctrines being smuggled into a bill to min the constitution.-The Earl of Carmareon observed, that, as he saw the general opinion of the house was against the bill, he would not press it to a division, but would withdraw it."

And thus the effort for gradual reform was frustrated, and fortunately, for the "gradual" progress would have been much the same as standing still. There were many members of both houses who thought with Lord Salisbury, thengh they did not speak out so plainly, that to regard wealth and population as a claim to representation, was one of the wildest doctrines of reform, and that its practical recognition would lead to the utter ruin of the constitution. 


\section{CHAPTER XX.}

MUNICIPAI AGITATIONS.

Considerable dissatisfaction had for several years been manifested by a portion of the inhabitants of Manchester with the management of its munieipal affairs. There was no elective authority in the town. The boroughreere, who, by ancient custom rather than of right, exercised the functions of a mayor, and the constables, whe were at the head of the day police, were eleeted at the lord of the manor's court leet, by a jury nominated by the lord of the manor's steward. The police eommissioners, whose duties were to superintend the night-watch, and the paving, sewering, and lighting of the town, consisted of such persons as being assessed upon a $£ 30$ rental, chose to come forward and take the onth of office. The inliabitants had no control over the first class of officers, and they had long shown themselves as anxious to apprehend radicals and put down reform principles as to detect thicres and prerent theft and robbery. The police commissioners, abetted by the court leet officers, were, in like manner, apt to forget municipal dutics in political; and there was a suspicion that, provided their servants and the tradesmen they employed were sufficiently loyal, there would not be a very sharp inspection of their accounts. Amongst the complainants were Mr. Chapman, a fruiterer; Mr. Nicholas Whitworth and Mr. William Whitworth, corn dealers; Mr. P. T. Candelet, a draper; Mr. John Dracup, a draper, and several other commissioners who, even at the risk of personal violence, kept rooting after abuses, and succeeded in bringing to light some things which certainly looked rery like jobs; for instance, it was diseovered that each horse kept by the 
commissioners, in addition to a fair allowance of corn, consumed bran to the amount of forty shillings' worth a week. Additional soures of dissitisfaction arose when gas became a necessary to the shopkecpers. The commissioners had, very wisely, established gas works, instead of learing the supply to any joint stock company. They borrowed money to ereet the works and put down the mains, repaid it out of profits derived, and borrowed more when the works needed extension; and thus they obtained a large amount of elear income, to be expended in public improvements, without the assessment of the inhabitants to the amount of a single furthing. But, in the early stages of the manufacture, there was reason for complaint that improrements, as well as the lighting of the town, to which the whole community ought to hare contributed, were effected out of the poekets of the gas consumers. At the time the consumption of gas was confined almost to the shopkeepers and publicans. It was not used in warchonses, offices, or dwelling-houses, or small factories, and the large spinning estahlishments made their own. Probally, not one-fourth of the ratepayers were gas consumers. The small trader, whose shop, situated in some dark narrow street, required much artificial light. complained that the enormous warehouses of the Bridgewater Trust, and the great factories of the Birleys, the M.Comells, the Murrays, and the Houldsworths, paid nothing towards the supply of the town's lamps with gas, while the whole of that cost was defrayed out of the profits derived from excessively high prices. A struggle was made by those who believed themselves to be unduly taxed, to have a reduction of the burthen. Those who escaped from this fair share of contribution, and thought that the gas consumers paid only a reasonable price for their light, opposed themselves fiercely to any reduction of the eharge, which at that time, was fourteen shillings per thousand eubic feet. The question became one almost of politics, and it was discussed with even more than political 
rancour. The taxed shopkeeper was the radieal, and the untaxed warehouseman was the eonservative. 'The reformers, beaten on every division, began to ask accessions to their numbers, and as everybody who was assessed upou a rental of $£ 30$ a year was eligible, it was not diffieult to persuade many to go and take the qualifying oath, and gain the opportunity of putting a elicek to "oppression." "The same facility was presented to the other side, and great numbers qualified to protect the town's funds from "spoliation." Thus the neetings of commissioners were constantly becoming more numerous and more storny, till it was not an uneommon thing to see eight hundred commissioners present at a meeting, and to witness proceedings as little deliberative and decorous as we sometimes sce in the front of the hustings on the nomination day at a contested election.

At a meeting held on the 30th of January, 1828, at which about $\mathbf{9 0 0}$ commissioners were present, it was intended, by the advocates for a reduction in the price of gas, to subnit a motion that it should be reduecd, so as to leave a elear profit of $£ 4,000$ per annum, to be applied either to the reduetion of the rates or the inprovenent of the town; but it was soon seen that there was little disposition on the opposite side to come to any amicable arrangement. It was mored that the boroughreere, Mr. Charles C'ross, should take the chair; but Mr. W. Whitworth objected, on the ground that Mr. Cross had not aeted impartially at the previous meeting, and mored that Mr. Candelet shonld take. the chair. It then became a question whether the election should be by ballot or ly show of hands, and Mr. Oswald Milne put that question to the meeting, and declared that the majority was in favour of the ballot; on which Mr. Hugh Hornby Birley demanded a serutiny, which was effected with difficulty, great delay, and nuch uncertainty, and then the rotes were declared to be-for the ballot, 418 ; against it, 463 . The question then became whether Mr. 
Cross or Mr. Candelet should be chairman, and it was put to the meeting by Mr. O. Milne, who declared that the majority was in farour of Mr. Cross. Mr. W. Whitworth, following the example of Mr. Birley, then proposed a serutiny, and that it should be taken from the police books, as he was convineed that of the names given in last there were unany of persons who were not commissioners, as well as of persons who were not in the room at all. Preliminary to the serutiny, tickets were handed round to obtain the names of all the persons in the room, that they might be compared with the list of commissioners. The tickets having all been handed in, scon after laalf-past one o'clock, Mr. Milne got on the table, and said he would amnounce the result of the scrutiny. "Nay, not the serut:ny," said Mr. John Gyte; "there has been no scrutiny yet; and the mecting understands that the scrutiny is to be made by comparing the names handed in with the names on the book." Mr. Milne paid no attention to this, and said, "'The result of the voting is that there are 520 for the boroughreeve, and 386 against him, and I declare that he is elected chairman. Mr. Cross, take the chair." Mr. Whitworth and all of his supporters within hearing protested ayainst this, and said that the serutiny should be taken in the way that had been agreed upon, and as the meeting had been given to understand it should be taken; but, as I was informed by several gentlemen who witnessed the transaction (for I was at the table below the hustings), Mr. Milne, instead of paying any attention to their protest, or to his own previous agreement, hurriedly held out his hand to Mr. Cross, who was at some distance, in order to pull him towards the table, over the heads of the commissioners who stood on the hustings. He was resisted in this attempt by their standing elosely together, and Mr. Whitworth called out, "Don't let him into the chair until a fair scrutiny is made; kecp him out." On this there was an outery, "Put him in"-"Keep him out;" and a general rush to the hustings from both sides of 
the room took place. As the commissioners cither could not or would not make way, Mr. Cross, who was standing upon a chair near the wall, put one foot on the shoulder of a gentleman before him, and seemed disposed in this way to reach the table; but the gentleman shifted a little to one side, and Mr. Cross, being unable to reach the table with his foot, slipped down. A cry immediately rose that he had been thrown down on purpose, and the confusion was increased, one party erying out that he was obstrueted by foree, and another that he had no right to be in the chair. Mr. Whitworth, who had been on the table in front of the hustings, then got over the railing, about the time when the boroughreeve had recovered his footing, and called out, "He has no right to be in the chair ; keep him out." Mr. Milne then stood forward, and ealled out loudly and repeatedly for constables, and said that if any one would get a warrant, he would swear that $\mathrm{Mr}$. Whitworth had committed an assault, and had urged on his party to acts of violence. The noise now was appalling, and the pressure towards the hustings, to see what was going on, was so great, that imminent danger from the collision of the parties was to be apprehended. At this period of the proceedings, fearing, from Mr. Milne's reiterated vociferations, that the boroughreere's personal safety was endangered; I jumped over the railing into the lustings, and going up to the boroughreeve, said, "Mr. Cross, I have on all occasions opposed your being chairman of these meetings, but I cannot sanetion violence, and the man who assaults you assaults me." But a few scconds' observation showed me that Mr. Cross was in no danger, for he was sitting ealmly on the table, and on this address he smiled and said, " $\mathrm{Oh}$, I am neither afraid nor hurt." Indeed all around the table was quiet, but several combats were going on at the extremities of the hustings, arising, as far as I could judge, from disputes as to who began the disturbance. On the left of the table a young man, a clerk, as I was told, in the 
constables' office, who had been desired to take a Mr. Wilde into custody, wus laying about him furiously and indiscriminately with a constable's staff, and, in the efforts to moderate his zeal, several contests arose, in one of whieh Mr. Norris, of Marsden-square, was in some danger of being treated roughly. On the other side of the table a zealot of the conservative sehool tore off from the upper part of the hustings a piece of wood, five or six feet long, and three or four inches thick, and brandishing it aloft, swore that he would settle his opponents; but some considernte friend forcibly dispossessed him of his formidable weapon. In front of the hustings Mr. Riehard Smith was engaged in a contest with a commissioner who had called him a liar; but some one having said, "Why, Mr. Smith; that is the usunl language here," he quitted hold of his antagonist's collar, and, with great good humour, let the matter drop. A very serious aceident, however, befel one commissioner, Mr. Evans, of Ancoats-street, who, though standing at several yards' distance from the boroughreeve, and taking no part in the disturbance, was aceused of being opposed to him, and, without any eeremony, was hurled from the hustings with such violence that he was driven head foremost against a sharp angle of one of the fluted columns, apd received a wound which, at first sight, seemed to be mortal, but which was more frightful in appearance than dangerous.

This riot gave great satisfaction to the opponents of local reform, and it was soon seen what use they intended to make of it. The tory Courier said :- " If the affairs of the town are to be conducted, as heretofore, by the whole body of police commissioners, the qualification ought to be raised from $f 30$ to $\mathfrak{f} 50$;" addling. "we are glad to find that a statement of all the circumstances of the outrages at the Town Hall have been forwarded to the secretary of state." The whig Guardian took the same course, saying:- "We fear the occurrences which have taken place at sereral of 
the late meetings, render the conclusion irresistible, that a new constitution of the body of the police commissioners has become absolutely necessary." The tory Chronicle stated that there were then 1,800 commissioners, and said: "It is now become obvious to erery respectable resident in Manchester, that some change must be sought for in the mode of conducting its public business." This change had been long desired by those who did not find it work so pleasantly as when a few conservative gentlemen had the business all in their own hands. In the meantime it was thought advisable to take legal proceedings against Mr. Whitworth, who was brought before the magistrates, charged with riot and assault, and after a long examination he was required to enter into his own recognizance in $£ 200$, and to find two sureties in $£ 100$ each to answer the charge at the sessions. Mr. George Hargreaves Winder,

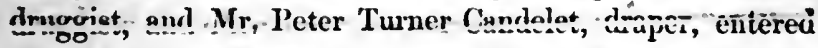
into the required recognizances. The prosecution eame to nothing, unless its instigators regarded it as something that they put Mr. Whitworth to a considerable amount of expense.

The hints as to the necessity of a change in the constitution of the police body were soon acted upon. In the papers of February the 23rd appeared a requisition to the churchwardens, to call a meeting of the rate-payers to consider the propriety of applying to parliament for an aet to confer on all occupiers assessed to the police-rate, at the amount of $f 25$ per annum, the right of roting in the choice of 240 commissioners from amongst those who might be assessed at the amount of $£ 35$ per annum. The principal names at the head of the requisition were-
H. H. Birley,
Joseph Green,
George Neden, Thomns Hardman,
Thomas Entwisle, James Beardoe, Charles Cross, Richard Warren, Fdmund Buckley, Henry Newbury, William Garnett, Thomas Sowler.
J. B. Wanklyn, Benjamin Braidley, 
and a number of others who had been boroughreeres, or constables, or commissioners, or churehwardens, or sidesmen, in quieter times, when humble men clid as they were bidden by men in higher commereinl station than themselves. Amongst the names were minglet those of $\mathrm{Mr}$. George William Wood, Mr. John Edward Taylor, Mr. Daniel Broalhurst, and other whig gentlemen who leaned a little more to the gentlenumly quietness of conservatiom than to the rough turbulence of radiealism. The meeting was in stormy one, as might have been expected, when the olject was to consider a proposil which went to exelude all who paid a rent of less than about $\$ 32$ 10s. (equivalent to

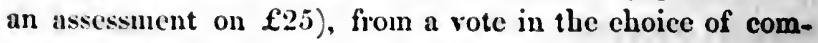
missioners. The resolutions proposed at the meeting were rejected by a majority of ten to one. It was then seen why. the churchwardens, parish offieers, rather than the borough-

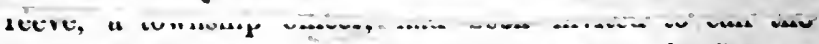
meeting. At parish ineetings the voting was under Sturges Bourne's Act, which gave power to an individual, up to six votes, according to the amount of assessment. The churehwarden, in his chair in the Collegiate Church, for, with the same design the meeting was held there, decided that the voting on this township nftiir should be under the Parish Vestry Act, and on the call for a poll, decided that it should then und there eommence. Mr. Shuttleworth then stood forward on the table and was received with loud cheers. He said that, " though he was convineed, from the astounding majority which the show of hands had exhibited, that those who were opposed to any present applieation to parliament would be equally vietorious under the Vestry Aet, yet as he considered the roting under that act to be, under the circumstances illegal, and the intention now declared of enforcing it, one of the most discredituble tricks, even in the contentions of party, he had ever witnessed in public procedings; and as he was also convinced by the violation of all fairness in the spirit with which the measure was 
pressed forward, that those who had undertaken it would, in defiance of any majority of their townsmen against it, however taken and however recorded, still proceed with it to parliament, - he would advise those who were opposed to it to do as he would do-take their hats and their leave together and walk off. The battle must be fought before a committee of the House of Commons; and the public of Manchester had so deep a stake in the conflict that they must prepare for the defence of their rights and interests in that field with the most determined energy and spirit. Time must be deroted, money must be raised, arrangements must be made without delay. If the public exerted themselves as they ought, the town would not be injured and disgraced by a police bill, founded upon what he could not but characterise as insulting, unjust, and factious principles. These observations were received with loud cheering, and Mr. Shuttleworth, Mr. Baxter, Mr. Richard Potter, Mr. Thomas Harbottle, and a great number of gentlemen in or near the hustings immediately left the hall, which, in the course of a few minutes, was nearly emptied. $\quad$ At the close of the poll it was found that out of 8,000 actual ratepayers, only 641 persons, whose votes numbered 1,610 , had roted in favour of the bill. So well had Mr. Shuttleworth's advice been observed,. that only six rotes were recorded against the bill.

Another meeting, convened by twenty-one police commissioners, was hell in the Town Hall, on the 5 th of Mareh, to take into consideration the propriety of petitioning against the proposed bill, Mr. William Harvey in the chair. The speakers were Mr. Edward Baxter, Mr. P. T. Candelet, Mr. David Holt, Mr. J. C. Dyer, Mr. J. Shuttleworth, Mr. W. Whitworth, and Mr. Richard Potter. 'The only speaker in favour of the proposed bill was Mr. J. E. Taylor. The meeting resolved unanimously that no new police bill should be applied for until some general agreement should be made,as to its provisions, and appointed forty gentlemen 
to oppose it, by deputation or otherwise, if the opposite party persisted in pressing it, in spite of the public opinion expressed against it. $\Lambda$ general meeting of police commissioners, to the number of 500 , was held on the 27 th of March, and they also resolved to petition against the measure. As the proposers of the bill declined to meet and confer upon its provisions, a subseription was commenced, several of the wards subseribed more than $\mathbf{E 1 0 0}$ each, and all hope of amieable arrangement being dissipated, preparations were made for a hot parliumentary contest.

On Friday, the 2nd of Mny, the new bill was brought before a committe of the Ilouse of Commons, a strong deputation being there to support it, and Messrs. R. Potter, Joseph Brotherton, Elward Baxter, James Hampson, P. T. Cundelet, and myself, as deputies from the ratepayers' meeting, to oppose it. Again an attempt was made to avoid the contest by a proposal to submit the question of qualification, the min point in dispute, to arbitration, but the promoters of the bill, as they themselves acknowledged, had received instructions from the boroughreeve's party in Manchester, to mitke no concession. 'The first day's examination wats with the view of proving the preamble. On Monday, the isth, the opposers of the bill agreed they would not rebut the eridence as to its necessity, as it was quito as desirable to repress the irregularities of the "high" party as those of the "law." On this intimation being made by Mr. Blackluurn, our counsel, the examination of Mr. Onwald Milue, the law elerk to the eommissioners, there fighting against his employers, which had been going on while the deputation were consulting, eeased, and the promoters of the bill proceeded in their support of the severul clauses, none of which were opposed till the arrival at the one which fixed the qualification of voters at an assessed rent of $\mathrm{f25}$. This was objected to, and an amendment propesed, that the qualification should be $\mathbf{1 1 0}$, the discussion of which was deferred till next day, oand the 
committee adjourned, having first expressed a wish that as the remaining clauses were matter of principle rather than of evidenee, the two deputations should meet, and come to some agreement about them. To this the deputation opposed to the bill offered no objection, although, from the refusal of their opponents to bring the points of the qualification to reference before, on the ground that they had no authority to come to such an agreement, they saw no probability of the boroughreere, Mr. Taylor, Mr. Green, and the rest of the promoters coming to any reasonable terms, particularly after having, as they supposed, obtained a victory in proving the preanble of the bill. However, the deputation opposing the bill sent to their opponents within two or three hours after the sitting of the committee, copies of all the elauses they intended to propose, and begged to know when Mr. Cross and his friends could meet them. Instead, however, of consenting to any conference, Mr. Cross addressed a letter to Mr. Baxter, couched in a somewhat insolent tonc, rejecting at once the clauses submitted to their consideration, and expressing their opinion that such clauses could never have been submitted with any desire to come to an agreement.

On Tuesday the committee again met and proceeded to the examination of Mr. John Thorpe, comptroller of accounts to the police commissioners, who stated that 3,800 persons were assessed at $f 25$ and upwards, and about 4,000 more at from $£ 10$ to $£ 25$. The latter, he said, consistęd of small shopkecpers, such as hucksters and green-grocers, elerks, warchousemen, and mechanics. This evidence was offered to the committee to prove the assertion of Mr. Adan, one of the counsel for the bill, that, even at the high qualification of roters proposed by its promoters, there would be a uumerous body of voters, und that the persons who wonld be excluded were of these classes which have enough to do in their own affairs, without any further interfering in police matters than to pay their rates. Mr. 
Thorpe stated, also, that the persons who now attended poliee meetings were not of so respectable a class as those who formerly used to nttend. In his cross-examination, he said, that 222 oseupiers, who were then police eommissioners, would not even have a rote in the elections under the new bill, being assessed at less than $£ 25$, and some at less thin $\mathfrak{f} 15$, and that even more than that number of owners, and persons who did not directly pay rates, then commissioners, would have no rote. This part of Mr. Thorpe's cross-examination not only proved the great extent of the disframehisement that would take place, but it saved the opposers of the bill the trouble of proving that the assessments were very much lower than the real reutal. Mr. Blackburn then proceeded to examine Mr. Thorpe from certain tables, which had been made up in compliance with a motion made by Mr. W'. Whitworth, at the meeting on the 16 th of $A$ pril. By these it was shown, that of the aecounts' committce, consisting of six persons, four, by the new bill, would be discjualified as voters, and five would becomo ineligible as commissioners; that out of ten of the searenging committee, six would be disqualified as voters, and nine would be ineligible as commissioners, and so on through all the committees. It was next shown, by a cross-examination upon these tables, that by far the best attendance on these subsidiary committees was by individuals who, under the new act, would not only be ineligible as commissioners, but who would not eren have a rote in the ehoice of the new managers of public affairs. It was also shown that the worst attendance was on the part of persons highly assessed ; for instance, in the lamp committee, two out of the three who were highest assessed, never attended at all, while on the fire-engine committee, consisting of persons at high assessments, two never attended at all, four only onee, threc only twice, two only thrice, and so on.

Mr. John Wool, member for Preston, son of Mr. Ottiwell Wood, formerly of Manchester, further elicited from Mr. 
Thorpe, that the management of municipal affairs was certainly "bette than it had been ten years previously, when it was notorious that, under the management of a very few commissioners, of " high respectability," so much as $\mathrm{f50}^{5}$ a year, for each horse kept, was charged for bran.

Mr. Woop.-Yow, Mr. Thorpe, you are obviously well acquainted with the business of the police. Do you think it possible that such - coandalous job could take place now ?

Mr. Thozpe.-I do not think it could.

Mr. Wood.-Are not all contracts mado now on the best possible terms?

Mr. Tronpe.-I believe they are.

Mr. Wood.-Are not the eommittees well attended ?

Mr. Thorpe.-They are.

Mr. Woop.-Yet a great proportion of those who attend are cosessed at a low rate?

Mr. Thozpe.-They are.

Mr. Wood.-Do you think the business, generally, of the committees could be better done than it is now?

Mr. Thonpe. - I do not think it could.

The parties for and against the bill were ordered to withdraw, and on their re-admission they were told that the committee, after considering what ought to be the qualification of roters and commissioners, had agreed to recommend that it should be on an assessment to the police rate on 120 . The counsel for the promotion of the bill objected to any decision as to the qualification of commissioners before any evidenee was heard on that point; but they were reminded that this was not a decision, "but a recommendation. The deputation opposed to the bill promptly resolved to agree to the qualifications reeommended by the committee, and an immediate communication to that effect was made to the boroughreeve. Our deputation, with the lordly letter of Mr. Cross in their hands, stating that be and the other members of his deputation at once rejected the elauses submitted to them, thought that after that independent course of action they 
could not again erade compliance by pleading that they had no authority vested in them. Ahout nine o'clock, however, a letter was received from Mr. Cross, saying that the deputation (Mr. Cross, Mr. 'Thylor, Mr. Green, and Mr. C. Smith,) had written to their "constituents," and that without instructions from them they were wholly unauthorized to agree to the qualifieations recommended by the committec! This was their third refusal to come to any agreement with the opposers of the bill.

On Wedncslay monning, Mr, Aduns proposed an adjournment till Mondiy, by which time, he said, the boroughrecres's deputation would have received instructions from their constituents in Manchester. 'This was opposed by Mr. Blackburn, who protested against keeping the opposers of the bill in town at a heary expense, merely because the promoters of the bill could not do anything without instructions.-Lord Stanley said that the deputation seemed to have much more limited powers than he supposed they had, and more limited thun other deputations had, for gentlemen were usually sent not to demand that one eourse should be followed, and no other, but to do what was best under all the cireumstances.-Mr. Adams replied, that the gentlemen felt it necessary to send for instructions, because, if the measures recommended by the committee were adopted, their friends in Manchester might deem it better to albandon their bill altogether.-Mr. Stanley said there was no oceision to wait for a reply from Manchester, for if the gentlemen there did not like the bill, they might abandon it in a future stage as well as now.-Mr. Adams then oljeeted to any decision being come to as to the qualification of commissioners, as that part of the bill had not been discussed. The last-mentioned member said, that the aloption of f20 voters bore a reference to the qualification of connmi-sioners. for the committee considered that if the one was raised, the other should be reduced. It would, he said, be lowering themselves indeed, if they were, 
instead of exercising their own discretion, to wait till eertain persons in Manchester made up their minds. - Sir James Graham said it would be quite derogatory to the dignity of the committee to suspend their proceedings merely because a deputation was sent which had no discretionary powers.-Mr. John Wood said it was strange that tho deputation should refuse to accede to the proposal, for, in their own statement, circulated amongst the members, they had said they would eheerfully submit to any modifications the committee might think advisable.-Mr. Joseph Hulme took the same course, and at length the committee resolved that the prayer of the promoters of the bill, that they should adjourn till Monday, should not be granted.-Mr. Blackburn then spoke very shortly, but pithily, and the members were left to thenselves to deeile. When the parties were admitted into the room, it was found they had fixed on $£ 20$ assessment as the qualification of roters. 'Then came the commissioners' qualification clause. After some discussion, the parties were again turned out-the opposers in full expectation of things being right, yet under the fear that it was possible that a muster might be made to raise it-the promoters obviously in great alarm. At length the door was opened, when Lord Stanley deliberately read over the elause, and instead of thirty-five, read twenty.

On Thursilay the committee, proceeding to other clauses of the bill, made short work of a very complicated system of election devised by Mr. G. W. Wood, and apportioned the number of comnissioners to each ward according to a scale, suggested by Mr. Brotherton, drawn up with a referenee to both the number of the population and the amount to which property was assessed. Mr. Sergeant, solicitor, was the only one present of the original promoters of the bill, and offered no opposition to any of the amended clauses, all of which were agreed to exeept one, particularly insisted upon by Mr. Candelet, Mr. Hampson, and myself, which was afterwards thrown out, to fix the price of gas at 
a rate which would leave a clear profit of ten per cent. per annum on the estimated value of the works. On Saturday the original promoters of the bill, who had, up to that time, shown no disposition to come to amicable terms, or to any terms, communicated to our deputation that they would allow the bill to pass without opposition, if the qualification of commissioners were raised to a $\mathfrak{£} 30$ assessment, and the number of commissioners for each district were in proportion to the amount which such district contributed to the rates. To aceede to this very modest proposal would have been to abandon half of what had already been gained, after a most vexatious and exeeelingly expensive contest, and the original opposers, now the supporters, of the bill gave a prompt refusal to the proposal.

The enre of the bill, during its progress through the IIouse of Lords, was entrusted to Mr. Baxter, Mr. Brotherton, Mr. R. Potter, Mr. J. Shuttlewortl, and Mr. David Holt, the belief being that a strong effort would be made there to restore the high qualification; and that such was the intention was soon proved by Lord Skelmersdale giving notice that he would move its restoration. But, after all the parale, and effort, and expenditure, and boast, and swagger, the promoters of the original bill eame, cap in -hand and with bated breath, to propose that if the qualification of commissioners were raised to $£ 28$, they would consent that the qualification of voters should be reduced to $\mathrm{f16}$. 'To this the now promoters of the bill gave their consent, and it was passed. My comment at the time, in my newspaper, was : " We must not look on the bill as the best which could be framed, but as the best which could be passed; and although it is very far from being one deserving unqualified approbation, and though it may be doubtful how it will work, there can be no difference of opinion amongst the independent and thinking part of our community, that we are likely to have much more useful commissieners at a qualifieation of $\mathfrak{£ 2 8}$ than at onc of $\mathfrak{£ 3 5}$, 
and that the control exercised over those commissioners will be much more effective when their election is in the hands of persons assessed at $\mathfrak{f 1 6}$ than if it had been in the hands of persons assessed at $£ 25$." In this contest the sum of $£ 2,400$ was expended by the original promoters of the bill, and $f 1,200$ by those who contended for its amendment. The former had no legal sanction for their expenditure, but, having a majority under the new constitution, they roted repayment to themselves, aceompanying the vote, howerer, with one that the opposers also should be repaid. The latter refused to receive the money, and insisted that both parties should bear the expenses out of their own pockets; but the original promoters held fast by what they had received, and when all hope of ther refunding the amount was lost, the original opposers who had afterwards become promoters, consented to aceept of the sum voted and set apart for their use. 


\section{CHAPTER XXI.}

TIIE AUTIOR IN DIFFICULTIES.

WuEN I purehased the eopyright and materials of Mrs. Cowdroy's Gazette I reecived assistance from some friends, and amongst others from one firm that opened a credit for me with a banker. The firm which was amongst the sufferers by the great commereial depression of 1826, became insolvent; and I had to repay to the bank the money which had been advaneed to me. This was the beginning of diffeulties which I need not detail. Demands came upon me faster than could be met from the profits of my paper. Towards the end of $1827 \mathrm{my}$ friends advised me to offer my creditors a composition, I did so, and the greater number had agreed to aceept it, when one of the persons who had become sceurity for me at the stamp-office, becoming nlarmed, gave notice that he expected the board to use the power it possessed of compelling payment. What was called "an extent in aid" was issued, and I suddenly found not only all my printing materials taken possesson of, but notices sent to all who owed me money that it was to be paid to government. The composition, the arrangements for which had been nearly completed, was now out of the question, and bankruptey was the neeessary result. I was in the eondition of the farmer, who, having laid out all his money in improvements, was broken down just at the time when the return for his outlay began to come in. I had added fifty per eent. to the cireulation of the paper, and much more than doubled its advertisements. It was yielding un income beyond my expenditure, and promised speedily to beeome a "good property." It was in the way of clearing off all debt upon it, but not speedily enough to 
satisfy the inmediate demands, and in this condition it was broken down, and I was, for the time, broken down with it. When I saw that the process of bankruptcy must take its course, but in the hope that the assignees who might be appointed for the sale of my interest therein, would not allow the paper to die out, and the value of the copyright to be lost to my creditors, I published the following address to my readers :-

?

"TO THE READERS OF THE 'GAZETTE.'

"At the commencement of a new year, it has been my eustom to offer to the readers of the Gazette my sincere and grateful acknowledgments for the support and patronage experieneed by me during the time I have had the pleasure, and I trust the not unimportant or useless task of holding weekly conmunication with them on matters of local and general interest. I do so again on the present oceasion with not less sincerity, although under circumstanges which, as affeeting myself, are painful and unfortunate, and to which, though of a somewhat personal nature, it seems proper for me publicly to allude.

"Ali ine oid subseribers to this paper know that, preriousiy to its coming into my hands, it had, for some years, been conducted under most disadrantageoms eireumstances. Its influence upon publio opinion was very limited: its advertisements, the most profitable part of a newspaper establishment, were excecdingly few; its type was fast wearing ont; and althongh if not a very obviously sinking concern, it was a matter of some degree of wonder that it did not sink. Still it lad a eirculation amongst those who were pleased with its consistency during more than a quarter of a century; it had a name and a copyright, and this name and eopyright, I purehased at a considerable price. Once the Gazetle had been a very different thing, and I looked upon it as eapable of being restored to and raised beyond its former condition. Wheu I turned over its pages, and conned its contents; when I saw what it was, and knew what it had been; and when I rellected on the wide scope which the inerease of the population, trade, and intelligenee of the district, aflorded for exertion, I felt as inany un enterprising agriculturist has felt when walking over the fields of a once well cultivated and prosperous farm, which, either trom the neglect or porerty of the eultivator, had become a wilder. ness; but from which, after a liberal outlay, there might still be 
expected a liberal return. Such a man, in such a pursuit, is often. too sanguine in his riews, and prone to look at what the farn may bring him years lenec, and atter he has expended his money in improving it, than to the return it can vield in the carly period of lis tenautey. In counting the fut ure gains from acres which are yet umproduetive, be will contidently lay ont his money in drain. ing and tremching, and plonghing, and hedgring, and planting (to say nothing of the too great price he may pay for his occupation of it), the land which is to give its harvest at a future period. And thus, while effecting unlonbted improvements, the man, if his capital be not great, thuds his means to be exhausted preeisely when the return of his outlay is about to be fully cujoyed; ind perhaps he sees the fruits of his labours pass into the hands of others who gather where they hase not strewed.

"Very much like this have been my calculations and conduct. I lnve eflected the improvement; I have changed totally the aspect of my concern. I have, during less than four years, raised the Gazette so far, that, in circulation, it ranks behind not more than five or six of all the conntry piners, und behind only one of the Manchester. papers. It has, under my management, nequired some importance as the organ of bold and independent sentiments, with regard both to local and nutional topies. It does actually yicld a handsome income at the present time. But having aceomplished thus much I find mysclf, for a time, at least, orerwhelmed with engagements, resulting, in a great measure, from my cfforts to improve my paper, and to make it that which it was eapable of being made.

"There are causes of cmbarrassment to which the case supposed benrs no analogy. The outgoings of a newspmper establishinent aro comparatively large sums, while all its incomings are snall. The former are certain, constant, and aduit of no delay. The latter are of such a nature, that the most incessaut watchfulness and effort are necessary to make them arailable. The accounts for newspapers, for alvertisenents, and for printing, are numerous beyond the conception of those who are ignorant of the details of such a business; and these are ahnost all credit aecounts; and these little credit accounto are precisely those which people in geueral eare lenst about punctually paying, and which it is therefore most difficult to collect. Orer this department, while labouring in the editorial field, to raise the character of the pajer, to inerease its circulation, and extend its advertining connexion, I have been unable to exereise that close and watchful superintendence which it required, and the effect has been 
much more than any person unacquainted with such a business could readily conceire. If, for having suffered these losses to aceruo for want of my constant personal superintendence of the department in question, I ain blameable, (which I do not deny,) I must be content to bear all the censure I may recire from those who have known what it is to feel their minds distracted by the long-continued and cerere illuess of those who are dearest to them, and who also know comething of the pressure with which this eril has weighed upon mo-a pressure which is now, I thank God, lightened in a great degree, and is, I trust, in a course of complete removal.

"I again offer to the readers of the Gazette my warm and sincere thanks for their patronage, and beg learo to express my hope that it will still be continued; for every thing which improres the condition of this paper, will improve the situation of my creditors, and facilitate my arrangements with theiu.

"Gazelte Office, January 12th, 1828."

This address brought around me many sympathising frends, including some of my heaviest ereditors, who tricd to soothe my feelings by assuring me that I had suttered because I was in adrance of public opinion, and by circumstances over which I could have no control, and that better times would come. Amongst other notes of encouragement, for which I felt grateful, was one from Mr. Egerton Smith, who, in the Liverpool Mercury of February 1st said generously : "The proprietors of newspapers who dare fearlessly advocate the causc of parliamentary reform, and of civil and religious liberty, and expose private delinquency, are beset with so many perils, that thcy ought, at least, to encourage each other, and especially in the hour of adversity. For some reason, for which we are unacquainted, the editor of the Manchester Gazelte seems to want cheering up a little just at this moment; and we trust our respectable and honest contemporary will not be offended if we take the liberty to clap him on the back. We have markel his political career, and have found him to be one of those public characters who cannot be spared in such times as these. We wero much coneerned to hear a rumour that the Gazctle was 
about to be relinquished, and we are much pleased to find this rumour unfounded."

The day cane for my appearanee before the bankruptey commissioners. The kind-hearted Richard Potter, one of my assignees, with tears in his eyes and a roice broken by emotion, uttered something of ill health at my home, and of mistaken calculations of success, and my examination was passed with scarcely ano:her word. I went from the meeting to the New Quay Company's warehouse, where the dead bodies were laid of a number of young persons who had been drowned that morning at the launch of a vessel in the river. I had scarcely seen death before, and the wet and livid bodies presented it in a frightful form; but I found myself, while contemplating the melancholy seene, reflecting, with some degree of enry, that after life's fitful fever they slept sound. The umerving thought held me but for a moment. There were duties to be done, and I resolved, with the help of Goll, that they should be done. I was spared to help forward, however humbly, by my voice and pen, many movements to promote the happiness of my fellow-men, - to see eatholic emancipation follow the repeal of the test and corporation acts, the passing of the reform bill, the abolition of slavery in our colonies, the reform of our municipal corporations, the reduction of the duty on newspapers, the adoption of the penny postage, the abolition of the monopoly of bible-printing in Scotland, a great impulse given to carly tuition, the repeal of the corn and navigation laws, and a wide recognition of the prineiples of peace, - to prove, notwithstanding my disastrous and almost heart-brenking business failure, that Manchester could support a thoroughly independent newspaper,-and to leave in my editorial place, after nineteen years of further not uninfluentiul labour, men disposed to carry out the principles which I had advocated, and a public prepared to demand, if it could not be had without a demand, an unshrinking expression, through the press, of reform principles. 
The Manchester Gazette passed out of my hands, soon afterwards to be incorporated with the Manchester Times, which was established by a joint-stock company, consisting of a number of gentlemen, several of whom had lost money by my bankruptey, but desirous to secure my public ser-, vices. In a spirit of deliente generosity to one who might, uncharitably, be considered as a fallen man, I was requested to draw out the prospectus in my own name, and to give my own assurance to the public that I had full liberty to carry out all the prineiples I had formerly adrocated, independent of any elique or party. In the first published number of the new paper, which appeared on the 17 th of October, 1828 , amongst other pledges of unabated and unflinching derotion to the eause of reform, I gave the following :-

"I shall often ask my townsmen wlether it is to be beliered that an assembly chosen by the people ever should have enacted measures to prohibit, until aetual fanine should have begun to rage, the introduction of eheap eorn from all the countries around us, when all those countries required from us, in exehange nothing but those manufactured goods, to the production of which the population has, by tens, and liundreds, and thousands, been turning the labour which formerly went to the eultivation of the earth; I shall often ask my townsmen, who are especially affected by the odious policy, whether the people's representatices, sceing surplus eorn abroad and surplus goods at home, and the proprictors of each needing that which the other wished to dispose of, would have decreed that the mutually beneficial exchange should not take place, and for no reason in the world but this, that a domineering aristocracy should, out of the hard earnings of industry, which are pail for the dear breal of home production, continue to derive the exorbitant rents which war and paper money formerly enabled then to exnct."

I believe that the public have given me eredit for the faithful fulfilinent of this pledge. There were other newspapers which adrocated parliamentary reform and the abolition of monopolies, but it was oceasionally and incidentally, not with the reiterated, earnest continuousness of the.$/ / a n$ chester Times, which waited not for the favourable tide 
of public opinion, but strove to create it; and I may be permitted to say, without any great amount of undue assumption, that the constant exposure, in its columns, of erery landlord-fallaey uttered from 1828 to 1838 , contributed in no slight degree to the lead which Manchester, from the latter period, took in the great movement which resulted in the repeal of the corn law. Certain it is that, during that memorable contest, I was often checred by the assurance of young, able, and energetic men, throwing their life and soul into the agitation for free trade, and its great anticipated result-the binding of all nations of the earth in the honds of peace-that their first lessons in a generous political economy were derived from me. I have passed through the sandy desert where no water was, and may be allowed now to look back, with feelings, approaching to exultation, to the few green ficlds that lie between.

The period at which I renewed my labours as a journalist was one of high hope. There was not such movement, but men's minds were in the way of preparation for movement. Some experiments had been made in the direction of frce-trakle, and made without ruining commerce; the test and corporation acts had been repealed, and yet the always-in-danger cluurch stood unshaken; the belief was gaining ground that Catholic Limancipation might be, granted, not only without utterly destroying, but without in uny degree endangering an enlightened Protestantism, and that a considerable reform of the representative system might take place without the extinetion of our "glorious constitution." The friends of ciril and religious liberty looked forwarl witl hope, the obstructives of progress with dismay.

The bigotry and conservatism which had distinguished Manchester and its neighbourhood, were not to be vanquished without a struggle. On the 21 st of Norember, 1828, there appeared in the Manchester papers a requisition, 
signed by five hundred and fifty persons, including fortyfour clergymen, calling a meeting of all who concurred with the requisitionists in the opinion that the concession of further political power to the Roman Catholies would be pregnant with danger to the constitution of these realms. A counter declaration appeared in the same papers, in which the subseribers, four hundred and fifty in number, expressed their regret that the harmony and good feeling prevalent should be disturbed by the agitation of the subject, and made known their desire to hare the question left to the calm consideration of parjiament. Amongst those who signed the declaration were a number of ehurchmen and tories, who had never before lent their names to anything so nearly approaching a liberal movement. Mr. Peel had been in Manchester in the early part of the year, and had cautiously avoided any pledge to stand firm in his opposition to concession; FIdon had been left out of office, and some rather strong suspicions had arisen that the Duke of Wellngton would yicld to expediency on the question. The anti-catholic meeting took place in the Manor Court Room on the following Monday, anĩ Mr. Lavender, who had suceeded Nadin as deputy-constable, stood at the door to exelude all who were unfavourable to the object of the meeting. I see I have noted at the time that "to the honour of those who were thus questioned be it said, that as their leaders will not forswear themselves to get admittanee into parliament, they would not tell a falschood to gain admittance into the court-room of the lord of the manor of Manchester." The chairman, Mr. Hardman, very wisely said that their object wus not discussion, but an expression of their fears of danger to the constitution. Mr. Norris, the paid chairman of the quarter sessions, a man of narrow intellect and confined views, moved the first resolution. Ilis main argument was, that if eatholic emancipation were granted, parliamentary reform would be demanded; " and then," he asked triumphantly, "what 
would become of our constitution? What would become of king, lorks, and commons? The motion was seconded by Mr. John Bradshaw, and of course carried unanimously. The other speakers or movers were Messrs. Joseph Birley, Francis Phillips, who made a stand for Protestant ascendaney, Mr. James Brierley, Mr. Benjamin Braidley, then rising into a very brief distinetion, Mr. Jeremiah Fielding, Mr. Charles Cross, Mr. Watkinson, who did not wish the king to go to his grave a "perjured character," Mr. Joseph Green, whose day of local power was now nearly over, and the Rev. Cecil Daniel Wray, who still holds a very luerative office in the chureh, notwithstanding catholie emancipation. The petition to the lords was to be entrusted to the Duke of Wellington, that to the commons to Mr. Peel. Alas for the expectations of our protestant ascendaney gentlemen! In three short months both of these statesmen were to be against them.

The Cheshire Brunswickers followed the example of the Manchester obstructives. A county meeting was held at Kuntsford on Monday, December 28th. It had been confidently announced that it would be attended by between twenty and thirty thousand persons: notwithstanding extraordinary exertions all over the country, not more than six or seven hundred came, including the women and children of Kinutsford. I'eel's ominous silenee, and the Duke of Wellington's expressed desire for dispassionate consideration, had prepared the minds of the more moderate for some feasible change, and they held aloof. Sir H. M. Mainwairing, a renowned fox-hunter, was called to the chair, and made a mild speceh. He was followed by the Rev. Sir. Philip Grey Egerton, who was equally cautious. Mr. II. C'. C'otton was also very morleratc. Mr. Trafford Trafford, of ( )ughterington, chairman of the quarter sessions, abused $O^{\circ}$ Connell, Shicl, and the catholic priests; but being a man not averse to patronage, if exerted in his own behalf or that of his family, forcbore to say much against the govern- 
ment, which might possibly turn and ask its friends to turn with it. The Rer. C. W. Ethelston reminded his hearers of the massacre of St. Bartholomew's day. Mr. W. H. Folliott, speaking near dinner time, was listened to impatiently. "Well," said he, "I will not detain you. A good dinner is better than a bad speech at any time. Allow me, however, to read you whit was done in the reign of Mary, which lasted four years, five months, and eleven days. In that time two hundred and serenty persons were burned to death, including five bishops. Think of thatthink of that; and twenty-one elergymen-think of that. There were also eight laymen and eighty-four tradesmen; and now listen, you husbandmen,-One hundred husbandmen were burned-aye, made beef-steaks of. Think o. that, farmers of Cheshire. How would you like to made beef-steaks of? Think of that." The farmers of Cheshire proved that they did think of it by voting for the resolutions. The leaders afterwards dined together, and drank "protestant asecndancy," all standing-who could standand thus the great county demonstration ended, the last that was attempted by the hitherto ruling party in ultra loyal and protestant Cheshire.

At a meeting of the Catholic Association, held in the month of December, Mr. O'Connell said he had ascertained that an emancipation bill was actually in the hands of the lawyers, and that ministers were making preparations to have it passed through both houses of parliament, at the approaching session. I had a lurking suspicion that the catholic leaders would be glad to barter, for the removal of their own civil disabilities, the political rights of their humbler countrymen, and I thus hinted it in my paper of the 28th :-

"The bill, ciescribed by Mr. O'Connell, is infinitely less objectionablo in its principle than that which had his corlial approbation in 1825, for its defect is only a foolish restrietion of catholic votes to subjects not connected with the church, while the bill which he and 
his collengues sanctioned, would have limited the elective franehise, nlready by far too narrow, and thus made a barter of popular rights for aristocratic principles. Mr. O'Comell and Mr. Shiel can havo no objection to sit in the House of Commons, cren with a limitation of their rotes to subjects uncomneted with the endowed church; for no sacrifice of principle is male when men enter upon the enjoyment of eularged privilages, though the enlargement be not so ample as they desired and contended for; but had Mr. O'Connell and Mr. Shiel obtained nn extersion of their own privileges, by consenting, in the name of their conntrymen, to a limitation of the elective suffrage, it could hace been one of the basest instances of selfish bartering that exer disgraced the annals of a country notorious for injuries inficted on the many for the lenefit of the ferc. We were amongst the few journalists who opposed the flagitions design to disfranchise the Irish frelsolders, and to place the Irish Roman Catholic priesthood as pensioners upon the produce of the taxes paid by English Protestants; and having denomeer the scheme as flagrantly disgraceful to the rutholic lenders, awd to the professed friends of reform, who professed it, we rejoiced that the bill of 1825 , with eneh adjunnts, was thrown ont of parlianent; and we now rejoice at the prospect of a measure, which, enanating in 1829 from an almost Eldon administration, slall more respect the rights of the people than that which in 1825 was sanctioned and supported by the whilom leaders of the Vinglish reformers. We shall have proof, indeed, that the schoolmaster is abroad, if the Juke of Wellington dare not attempt an abriclgnent of popular suffrnge, which Burdett and Brougham proposed, and hal they had the power, would have carried into effect!"

The base bargain was made, after all! The boon and the blow were aecepted together-the boon to the leaders, the heavy blow to their generous and faithful followers. Miss Martineau, in her valuable "History of England during the Thirty lears' Peace," says :- "On looking back to this time, nothing is more surprising than the quietness with which the disfranchisement of the forty-shilling freeholders took place. 'There were some few who saw and exposed the badness of the proceding, but they werc very few; and the very men who ought to have understood and been faithful to the prineiple of the case,- the very men who, in the same session spoke and roted for parliamentary 
reform, helped to extinguish the political liberties of the forties! Mr. Brougham regarded it as the almost extraragant price of the inestimable good which would arise from catholic emancipation. Sir J. Maciutosh, declared it a tough morsel which he had found it hard to swallow. Lord Duneannon, Lord Palmerston, and Mr. Huskisson tried another method. They did what argument could do to obtain the inestimable good without paying the extravagant price which they did not conceive to be necessary. If they had been duly supported by all the friends of parliamentary reform, there is little doubt that the relief of the eatholies might have been obtained without the saerifice of 00 vast an amount of political right. But among the silent and idle was $O$ Connell, who threw orerboard his beliered. ' Forties,' after pledging his life to destruetion, and his soul to perdition, if he ever again slighted their liberties; and in a case where $\mathrm{O}^{\circ}$ Connell so failed, we have little power of censure to share for meaner offenders." My censure, the censure of one of the few, " the rery few," who protested against the base bargain, extends to all the offenders, great and small. It was not Mr. Brougham who hatd to pay the extravagant price; it was not Sir James Macintosh who had the tough morsel to swallow; it was not Mr. O'Connell who made a sacrifice. The act was a wholesale disfranchisement of the poor to obtain privilege for a few of the rich. It reduced the electoral body in Ireland to such a small handful, that Lord John Russell's administration, in very shame, because the whole country was erying shame on it, was obliged to come forward, in this year 1850 , with a tinkering measure to remedy the eril inflicted twenty-one years beforc. It was sickening to contrast the pertinaeity with which the House of Commons defended the privilege of a handful of corrupt roters in a Cornish borough with its hot-haste in disfranchising 200,000 voters in Ireland.

While indulging in the hope of reform I saw that, to make an improrement of the representative system pro- 
duetive of really good government, instruction must be widely diffused amongst the people, and that instruction, to be effeetive, must be commeneed yearly. Sehools for Infants had been established, but the system had made little progress. Samuel Wilderspin had done some good by attracting attention to the advantages to be derived from very early tuition. Bishops and lords had tried to do so, but with little suceess. Wilderspin illustrated his plan. He earried a sehool with him, and cxhibited it before the admiring eyes of the benerolent; and tears from the well-spring of the heart, and smiles irradiating lovely countenances betokenel the triumph of the simple and the beautiful exhibition. Societies were formed, and schools were built, and hopes were indulged that the infunt race was speedily to be religiously and morally instructed, before vicious habits could fasten themselres with an iron grasp upon the infant mind. But to build new schools was an expensive process ; the initiative was eostly, and the subsequent required support was costly. The recipients of the benefit, parents among the poorer elasses, were not much disposed to pay for a good which they did not very well understand. The Lady Bountiful was very kind; the rich folks were very kind; it was a nice thing for their little ones to sing nice little songs and to behare pretty; but "really twopenee every week was a good deal for a poor man to pay." And some doubted the good to be derived. They lad not felt the want, and had not sought the benefit. It was a new thing proeeeding from the rich without consultation with the poor, and might be, after all, only another seheme similar to the charity school, where the principal thing was how poor men's boys should pull off their caps, and peor men's girls should make their eurtsey to the squire and the parson, and the squire's lady and the parson's lady. Sad perversion of thought, ecrtainly; but those who entertained it had not enjoyed the benefit of early tuition, and the doubt was excusable. 
It struck me that something more practicable might be attempted, and I suggested it. All the Sunday schools stood invitingly open six days in the week; why not bring them into daily use? A sum of $£ \notin 100$ or $£ 500$ would be requircd to build a sehool for infants. There were hundreds of places ready built, used only on the Sunday, ready for additional use at a trifling expense. The mere suggestion gave a greater impulse to that system of teaching than it had previously reeeived. Another suggestion greatly lessened the pecuniary responsibility for eurrent expenses. To render the schools, as nearly as possible, sclf-supporting, it was necessary to have a fitir number of scholars attending and paying constantly. That could not be had without couvincing parents that it was their interest and their duty to send their children, not oceasionally, but regularly. I sought out school rooms where I could delirer lectures on the subject. Parents were called together by bell or handbill. They were told that the main support of the schools, almost the only support of the sehools, must come from them. They were told that reading and writing were only parts of edueation-not knowledge, but only tho means of obtaining knowledge; and that the training of the affections and the conversion from bad habits, eren were reading and writing not attained, war_a_ and a most important part of education, well worth paying for. Where such explanations were given, the schools were prosperous and nearly self-supporting. Where they were not giren, the main obstacle to sueeess remained, and the sehools languished, a heavy hurden on the hands of the benerolent persons who estublished them.

Seeing that these gratuitous lectures, delivered in many towns in the manufacturing districts during the years 1828 and 18:2, had caused the establishment of a number of suecessful schools, I published a sixpenny tract on the subject in 1830, which was widely circulated. In the preface to a third edition of it, published in March, 1832, I said;- 
"At the period when I send this edition to the press, there is $\mathrm{m}$ additional incentive to every labourer in the vineyard of instruction. The probability of a great extension of the elective suffrage makes it the duty of all who have the welfare of their country at heart, to promote the means of enabling those to whom the right is to be extended, to exereise it for the public good. I know of nothing more likely to effict so desirable an end than the establishment of schools which not only instruct the ehild, but make, it a most influential teacher of the parent, by awakening a pereeption of social relations, and the obligation of social duties.", $\Lambda$ fourth and stereotyped edition was published in March, 1847. As the subject of national edueation has recently excited much discussion, as great encourngement has been given to voluntary effort, by the exhibition of what it has already done, and as there is a wide-spread eonviction that religious and moral instruction eannot, without great difficulty, be conreyed to considerable portions of the community unless it be commeneed before the labour of children, however small its reward may be, becomes important to their paresits, I may be permitted here to express a hope, that a noble superstructure may rise upon the foundations which have been laid. 


\section{CIIAPTER XXİ.}

THE DARK HOUR BEFORE THE DAWN.

The recollection of a pcriod of general distress, some twenty years back, is like the remembrance of a longcontinued illness at the same distance of time. In both instances there is an impression of misery endured, but it is softened by the lapse of years, its most painful circumstances forgotten, and the remembrance is scarcely more than that of a vague but painful dream. But in the case of illness, suppose the sufferer has written down an account of the continuance of his disease, day after day, week after week, and month after month; through the dreariness ot winter, made more dreary by despondency; through the hopeful spring, without hope; through the joyous summer without joy; through the cheerful autumn, without other thought than of falling leaves and decay, to another dreary winter, without the slightest prospect of a favourable change,-suppose such a journal written, and read after a lapse of twenty years, every circumstance is recalled with a vivid strength which is almost overpowering. Such feelings have I experieneed in looking over the file of my paper for 1829 , for there is recorded the "state of trade," week after week, throughout the year, and every week there is a record of deep and still deepening distress.

In January, it is noted that at Stockport, in consequence of the refusal of the operatives to submit to a reduction of wages to the amount of ten per cent., no fewer than fifteen establishments had been stopped, and two thousand persons thrown out of employment; in the beginning of February that ten thousand were out of employment in that town, while the failure of country drapers was checking the spring. 
trade in Manchester; in March, that the spinners had given notice of working short time, so as to make only five days in the week; in $A$ prtl, that there was no amendment; in May, that the Stockport hands were still out, and that wages elsewhere were undergoing further reductions; in June, that some employment was " hoped" for; in July, that there were some indications of inprovement, but without any effect on prices or wages; in the same month, that, notwithstanding the long tun n out in Stockport, stocks were not diminishing, and wages continued to fall; in August, that the distress was deepening all around, profits and wages daily becoming less; in September, that the shophecpers, depending on the expenditure of the working classes, were in deep distress; in October, that the downward progress of wages and profit still eontinued, and that the condition of the weatrer was truly deplorable; in November, that the peace between Russia and Turkey had brought a few buyers into the market for low-priced printed goods, but that for every other description of goods, there was little demand; and in Deember, that everywhere in the manuficturing distriets the gy eatest distress prevailed, and that wages were still filling. And that the year, commencing disastrously for both masters and men, ended, withont an interval of relaxation from distress, scarecly with an interval of hope, in a depression of trade almost unexampled, bankruptey and ruin threatening the employers and utter starvation the employed.

During all this downwurd progress, the press, with very few exceptions, laboured carnestly to persuade the public that the distress was only temporary. 'Trade was always to be better next week or next month. In winter, it was to be better in the spring; in spring, it was to be better in the summer; in summer, it was to be better in the autumn. The writers scemed to think, thut all that was wanted was "confidence," and that prosperity could be restored by confident and reiterated assertions that things were about 
to mend. The Manchester Guardian was in the front rank of the lopeful, or professedly hopeful; and though it had to confess, week after week, the delay of the prognosticated improvement, there was always some reason given for the delay, and new prophecies made that the good time was coming-any reason but the true one. The truth was, that the press generally was comnitted as to the effect to be produced by the withdrawment from eireulation, in April, of Bank of England and other notes under the value of five pounds. Almost every journalist of the period held that the bank had, at the end of 1828 , made provision for that change, and that the consequent inerease in the value of money, and deerease in the value of other eommodities, had already taken place. In support of this opinion, every suecessive proof of depression was declared to be only temporary. I followed Cobbett's opinion to a eertain extent, believing that money would continue to inerease, and other commodities to decrease in value, throughout the whole of 1829; and I earnestly and reiteratedly pressed my views on the community, convineed that there was more safety in looking the danger straight in the fuee than in indulging groundless hope of a favourable change.

The misehief done by representations that the distress was only temporary, was soon manifest. The working classes could not understand why, under only a temporary depression of trade, a constant reduetion of their wages should go on. If trade was to be " better next week," why were weavers to be diseharged? If yarns were to be more in demand " next week," why were the prices of spinning to be redueed? If manufucturers were all to be prosperous, by and by, why wre working men to be redueed to the condition of paupers in the meantime? There was a great "turn-out," and employers took little pains to explainperhaps, like the enployed, they did not understand-their actual position; and the two elasses were arrayed against each other in a bostility which dnily beeame more bitter, 
each taking that antagonistic position to the other that they should have taken agninst what occasioned the distress of both-ruinous restrictions on trade, and a heavy aggravation of the burthen of taxation, by the altered value of money, without a corresponding reduction of the public expenditure.

On Monday, $\Lambda$ pril 27th, the distressed silk wearers of Macelesfield, who had previously borne their privations with exemplary patienee, assembled in the Market Place, to the number of a thousand, and procecded to Messrs. Brocklehurst's factory at IIurdsfield, where they demolished all the windows in front of the building, and dispersed before the recruiting partics in the town could be put under arms. On Tuesday, Wednesdny, and Thursday they. paraded the streets with flags inseribed "We only wish to. live by our labour." On Wednesday a number of men at Rochdale, who had turned out, met, and went to the wearers who were employed, demanding their shuttles. On Thursday the factory of Messrs. Chadwick and Co. was surrounded by a great erowd, some of whom entered and destroyed a great deal of machinery, and at Mr. Robinson's and Mr. Ashworth's factory the same mischief was perpetrated. The military were ealled out, but arrived too late to prevent the mischief. On Friday sixteen men were committed for trial at Lancaster for taking part in these riots. An event more melancholy was to follow. When the prisoners were lodged in the lock-ups, the dragoons retired, leaving the place guarded by eleven soldiers, including a sergeant and corporal, of the 67th. Soon after the horse soldiers were out of sight, the mob began to rally, and about eight oielock some stones were thrown at the soldiers on guard, and in a short time they fell in such showers, that the soldiers began to entertain fears of their own safety, and the scrgeant told the crowd that if they did not desist, he should be eompelled to order his men to fire. $\Lambda \mathrm{s}$ this threat produced no effeet, he ordered two 
men to fire, which they did, taking care, however, to fire high. The moment, howerer, that it was seeen that neither of the shots had taken effect, the crowd, which had retreated, began to rally, and again to close round the soldiers and assail them with stones. The men seem now to have been in great danger, and the sergeant, acting, as he says, under the belief that the prisoners might be rescued, ordered the soldiers to fire. The command was immediately obeyed; but it would seem as if the crowd kept pressing upon them, shouting for the rescue of the prisoners, and throwing stones with the utmost fury. The soldiers having loaded again, fired, and their volley must have been dreadfully destructive, for almost every shot took effect, and six or eight persons fell. The mob, secing this, instantly took to flight, and the dragoons, arriving soon after, cleared the streets.

Riots in Manehester were less fatal, but more destruetive of property. On Sunday, May 3rd, a meeting of hand-loom weavers, the most deeply distressed portion of the community, was held at Harpurhey, at which it was resolved that the power-loom weavers should be invited to leave the factories next day, rather than submit to an intended reduetion of their wages. On Monday a number of persons congregated in St. George's Fields, proceeded thenee to Mr. Guest's factory in Union-street, and made his weavers leave their looms. Hitherto their intentions seem to have been to get the men to leave their work; but when they got to another factory in Mather-street, belonging to Mr. Twiss, they were not satisfied with requiring the men to leave their work, but broke into the mill and eut to pieces all the warps in the loons, and broke the reeds and every thing that was easily destruetible about the looms. They then set alrout tossing the webs into the street, and the street, for fifty yards on each side of the factory, was literally corered with eloth trampled into the mud. The mob then proceeded to Mr. Harbottle's factory, in Pollard-street, and 
having effected a forcible entry, they at once set to the work of destruction, as if in their unclecked progress they had entirely lost sight of their first intention, for no invitation was given to the weavers to turn out. Here the misehief was much greater than at Mr. Twiss's. The windows were instantly smashed in, and the destruetion of machinery was systematic and effeetive. Forty-six powerloons were instantly rendered useless, a single blow with a sledge-hammer being sufficient to break the east-iron framing, and another to destroy the regulating pinionwheels. In a spinning-room below less evil was done, for the spindles are not easily broken; but in a long shed, one story in height, containing nincty-two dandy-looms, the destruction was eomplete. One man on each side, with a single eut of a knife, eut through the warp, and with another the healds, while another man on each side followed, and with one blow broke the frames, and with another the wheels. After having demolished the whole of the windows in front, they went leisurely off. All this was done in less that an hour from the time they left St. George's lields. They then came back in the direetion of Mr. Guest's, from which they had previously induced tho weavers to withdraw. They scemed now flushed with suecess, for, inmediately on coming to the factory, they set to work, knocked out the windows, and in a quarter of an hour fifty-three power-looms were broken, and a vast quantity of warps tossed out of the windows and thrown into the eanal, which was corered with them, as the road had been at 'Twiss's with webs. By this time the beadles, with Mr. Lavender, the deputy constable, at their head, had arrived; but this foree was soon disposed of. The police, finding theniselves unable to make head, retired prudently, and, though pursued by the mob, they contrived to lay hold of two men, who were pointed out to them as having been seen throwing stones at the fictory windows. They finally took refuge from the showers of stones which were thrown 
at them in the Albiou Hotel, where some of the magistrates were by this time assembled. The mob were, in the mean time, taking advuntage of their victory; and while a part pursued the eonstables, another part proeceded to the factory of Messrs. J. and J. Parker, in Ludgate-street, St. George's-road, who had taken 3d. per eut from their wages. The mob made several attempts to burst in the door, but this, for a long time, withstoood their efforts, and, in the mean time, others were demolishing the windows by throwing stones at them. The door was at length burst in, and the looms and webs were disposed of in the same nuanner as the others. This method being, howerer, a somewhat slow process, and several alarms having been given that the military were coming, the factory was set fire to in several plaees. The building was about forty yards long, about twenty wide, and seven stories high. There was a brisk breeze, and as all the windows on the undermost floor were completely knocked in, the fire spread most rapidly, and in little more than half an hour it was all one tremendous flame. The blaze from the one window joined the blaze from the window above it, so that the whole was one immense mass of vivid flame. The houses in the strects on three sides of the factory were set fire to by the heat. Some of these were at the distance of thirty yards from the faetory, and it was only with the utmost exertions on the part of the persons who resided in them that they were saved from the flames. Almost all the furniture was removed out of them, there being at one time scareely any hope of saving the houses, the fire having caught hold in so many places at once. On the entrance of the mob into the lower story, Messrs. Parker and their assistants retreated to the stairease leading to the sceond story, where they remained for the purpose of opposing any attempt to penetrate to the upper room. They had not been there long, however, when the progress of the flames, whieh began to aseend on all sides of them, rendered it necessiuy to 
depart, and they accordingly escaped through the fire, with considerable diffieulty, and retreated to the house of their overlooker, which adjoins the faetory gates. The difficulty of escape was much increased by the flames issuing through the two doors opposite each other at the foot of the staircase, and by the ineendiaries throwing staves and other missiles into the door of the room on the second story, where Messrs. Parker and their assistants were, with the view, as it would appear, of preventing their escape. Mr. Parker eseaped with the loss of his coat and hat, which he had placed in the counting-house. While this was going on the magistrates and the peace officers were waiting at the Albion Ilotel for the arrival of such a military force as was to be had. A part of the military force which was in Manehester had been sent to Rochdale, and a part to Macclesfield, to quell the riots in those towns, and the remainder on Monday morning set out for Liserpool, on their way to Ireland. Having gathered together twelve soldiers of a recruiting party, some armed with bayonets and one with a pistol, Mr. Lavender put hinself at their head, and led them to Messrs. Parkers' factory, where they arrired just after the rioters had dispersed, and the fire had gone so far ahead as to render-any attempt to save the factory out of the question. Shortly after, Mr. Foster and Mr. Greaves, two of the magistracy, arrived at the same spot, at the head of about twenty dragoons. All, however, that they could do was to ride through and preserve order in the neighbourhood, which was now exceedingly crowded by persons flocking from all quarters to learn the cause of the disturbances. Though there was no further manifestation of any intention to riot, they continued to parade the streets during the greater part of the afternoon and evening. The terror, of course, spread over the town, and a great many of the shops, especially in that quarter where the factories were situnted, were elosed. Several of the masters of other factories procured fire-arms, and now and then fired a shot 
to show that they were prepared to defend their property in case of an attack. On the Tuesday and Wednesday great alarm continued to prevail throughout the town, for although an accession of military strength prevented further attacks, mobs suddenly congregated in particular places, and sacked the provision shops, and levied contributions in money and food from private houses, dispersing before any force could be brought to bear against them. By Wednesday night order was restored.

At a time when masters were regarded by the working people as grievous oppressors, and when the working people were regarded by their masters as unreasoning and brutal ineendiaries, the duty of a journalist was not easily fulfilled. I endearoured to call the attention of both to the real causes of the distress which was prostrating both. In a long address, in my paper of the 9th of May, I showed how the corn law had limited the demand for goods and reduced the wages of labour; I dwelt on the effect of increasing the value of money, and consequently reducing the price of everything except corn, while taxation, in the fifteenth sear of peace, was as heavy, the different value of money considered, as it was during the war; I represented the injurious effect on wages oceasioned by the great immigration from Ireland of poor creatures who were ejected by the landlords from their native soil in tens of thousands; I counselled petitions for a repeal of the corn law, for a great reduction of taxation, for the extension of a poor law to Ireland, and, as a guard against the recurrenee of misery, for a thorough reform in parliament. Newspapers were then serenpenee, which placed them beyond the reach of the mass of the people. My appeal was printed as a penny pamphlet, and the sale of thousand after thousand, for weeks together, showed that, amidst the bitter and foolish war of classes, there were many anxious inquirers into the real causes and eure of the distress.

By this time Colonel Thompson's admirable Catechism of 
the Corn Laces had appeared in a cheap form, was much read, and conveyed much useful and exreedingly well-timed instruction. I wisled to circulate its wholesome truths and fallacy-destroying arguments still more widely, and the proprietors of the Manchester. Times, always ready to pro-: mote the public good, cheerfully aceded to my request, that four thousanil copies of it should be printed and given away with the paper. This was done in $\Lambda$ ugust, greatly to the promotion of that thorough knowledge of the eorn question, which, nine years after, made Manchester originate and lead the great free-trade morement. Nor was this diffusion of knowledge, on this one point, without more immediate effects. The reform bill itself was hastened on mainly by the conviction, that without a great organic change in our representative system the landlords' monopoly could not be destroyed. There was good seed sown in those unpromising times. The humble country journalist, when acensed of ashing for the impracticable, eould point to Bentham, and Thompson, and Bowring, who, in the Westminster Review, were convincing the elucated elasses that radical reform in representation and commercial poliey, was, after all, not the very friglitful wild-fowl it had been taken for ; and with the example of such a triumvirate, he went on determinedly on his way, hopeful:y, in spite of every discouragement to hope. $\Lambda \mathrm{fter}$ this dreary 1829 , the first number of my paper for 1830 contained the whole of a fortheoming article by Colonel Thompson in the Westminster, on Radical Reform, which thus conelnded:" Hschew violence; cultivate educntion from A, B, C, upwards; hurry nothing, -it will all come in time, like the breaking up of a hard frost. Pull down an abuse when you can, especially where it is one, like that of slavery in the West Indies, whose supporters support all the rest. Go on, quietly and perseveringly, and fear nothing. There will be no revolution, no disturbance, no violent cluanges,any more than a child, of a span long, turns into a grena- 
dier. Sensible men are not to endure an evil for ever, through a vague fear of its removal being something they have not heard before, Do something; do a little; do more when you can. Keep the stone rolling; and see if you do not end by proring to all ranks and orders, exeept the downright plunderers, that radical is your only wear."

In the first week of 1830 Willian Cobbett delivered four lectures in Manehester to erowded audienees. Ten years before, on his return from the United States, the authorities notified to him that he should not be permitted to pass through the town. Many of his hearers were persons, who, at the former period, approved of that extraordinary exercise of power. Ilis leading propositions were, that lessening the quantity of the currency had increased its value; that the increase in the value of money had inereased the elaims of all ereditors, especially the public creditor; and that the fall in the price of every commodity, without a correspondent reduction of taxes, had oceasioned intolerable distress. His wonderful power of illustration, on these few propositions, engaged the deep attention of crowded audiences every night, and the thunders of applause, with which he was greețed at the elose of the course, must have made some amends to him for his seurvy non-reecption in December, 1819. 'Two omissions, however, were remarked upon by even his ardent admirers, the monopoly of the corn growers, and the want of an adequate representation in the llouse of Commons. His then rival Hunt, a man of far inferior abilities, even as a speaker, had much sounder notions on the corn laws; and Cobbett seemed less anxions tọ have parliunentary reform than that he himself should be a member of parliament. He said that ere long he would sit on the same bench with Mr. IIuskisson, but it was long after Iluskisson's death before he oltained a seat in the legislature. Another lecturer had visited Manchester in the previous year, Mr. J. S. Buckingham, whose really able exposition of the East 
India monopoly exeited a eonsiderabie share of public attention, and led to a public meeting on the 21 st of January, at whieh spirited resolutions were passed in favour of free trade with India and China. The principal speakers were, Messrs. G. W, Wood, John Shuttleworth, Robert Hyde Greg, and Mark Plilips; and they had the aid of some gentlemen who, though they saw nothing alarming in the prospeet of free trade with India, would have been frightened at the notion of having free trade at home-no harm in selling their calienes to John Chinaman, but great misehief in receiving brother Jonathan's corn. They were, however, taking one step in the right direction.

$\Lambda$ demand for some reforms at home speedily followed. On the 2()th of February appeared a requisition for a meeting, to be held in the Town Hall, to take into consideration the propricty of addressing parliament on the distressed state of the country, and of petstioning, that an immediate reduetion of the taxes be made, and that eommerce be not disturbed by again altering the value of the currency. I am tempted to give the names of all the requisitionists :-

William Iforsley,

Alexander IIorsley,

S. Y. Bailey,

Janes Wilde,

John Hulme,

James Bayley,

Willian B. Bayley,

John Read,

J. Smith,

Robert Sykes,

Ben. Ilolbrooke,

John Jackson,

James Hardman,

Robert Bunting,

James Ashworth,

Thomas Jarien,

Thomas Mloor,
Robert Lees,

Thomas Deane,

II. J. Barker,

II. Preseott,

John Samuels,

Gerard Cowell,

Johu Wallis,

Joseph Thompson,

Fdward Shaweross,

Ben. Sanclford,

James G. Frost,

Edward Daniel,

Thomas Johnson,

Jog. Dickinson,

P. W. Danby,

John Todd,

Samucl Prince,
John Ashworth,

James Cunningham,

John Hunt,

William Yates,

J. S. Ormerod,

Sanuel Pullein,

Robert Wyatt,

William Labrey,

W. B. Grime,

Thomas Goadsby,

F. Goadsby, jun.,

Richd. Iutchinson,

James Crankshaw,

W. D. Coddington,

R. H. Greg,

John Ashton,

Richard Potter. 


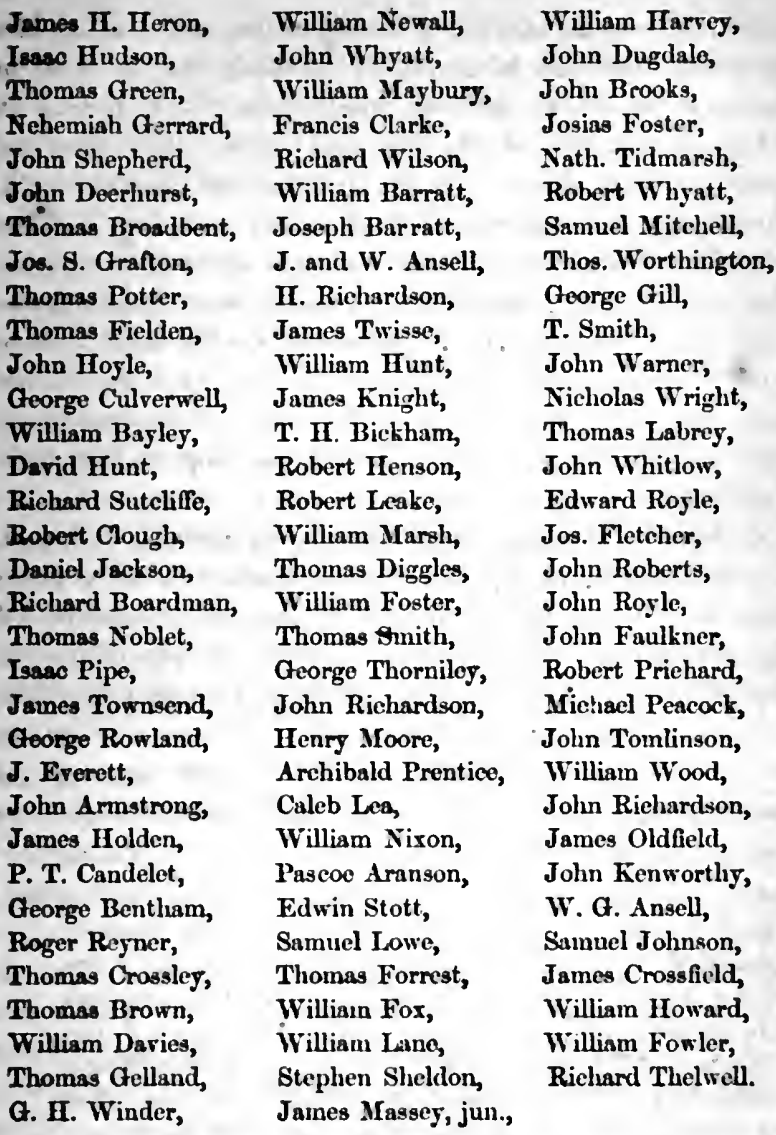

The boroughreeve, Mr. Bulkeley Price, and the constables, Mr. Ldmund Buckley (afterwards member for Neweastle-under-Lyne) and Mr. R. C. Sharp, appointed the meeting to be held in the 'lown Hall, on the following Thursday, the first time that any meeting, for any such purpose, had been held there. The first resolution was :"That the great manufacturing district, of which this town. 
is the centre and the mart, notwithstanding the unwearied and the incessant labour of its inhabitants, is suffering under a pressure of distress which, except in short periods of depression, is wholly unexampled in its extent and severity." It was moved by Mr. Richard Potter, who, in deseribing the wretehedness of the poor man's cottage, became so overpowered by his feclings as to be unable to proceed. Mr. John Shuttleworth, in a very effective spech, gave a statement of the enormous cxpenditure from the commencement of the war to that period, the fifteenth year of peace ; alluded to the bankers' and the landlords' monopolies at home, and the tea, sugar, and timber monopolies abroad; and coneluded by saying:- "The calamities under which this country is suffering arise from inordinate and unequal taxation; from the restrietions on the trade in corn, which a sordid aristocracy, for its own advantage, has had the power, owing to the unfortunate constitution of our legislature, to inflict upon our nation; and from those monopolies which, to the disgrace of our commercial system, are perpetuated to gratify the selfishness of the powerful few, and at the expense and to the injury of the powerless many. These are the causes of the present gencral and umpreedented distress, and the means of alleviation, therefore, are clearly to remove those causes, to repeal the restrietions on the trade in corn, to abolish all monopolies, and to reduce taxation." This speech was received with loud and reiternted cheers, but the meeting would not pass the resolution excepting "short periods of sudden depression." An amendment, that these words be left out. was moved, and it was carried by acclamation. Mr. Robert Ilyde Greg moved the next resolution:-" That much of the distress under which the people suffer is to be traced to the enormous amount and unequal pressure of taxation; un amount which this meeting is of opinion is unnecessary for the purposes of a government anxious only to promote the public welfare." He exposed the inequality 
of taxation, and compared the extravagance of the nation to that of an indivilual who constantly drew on his banker without making deposits; said that to have a reduction of taxes we must have a reduetion of expenditure; and declared that the cost of our army, our nary, our colonies, and erery other branch of public expenditure, must be cut down to meet the exigeneies of the country. The motion was seconded by Mr.. John .Brooks, afterwards to distinguish himself by his encrgetic opposition to the corn law, and his munificent support of the funds required to ngitate successfully the question of free-trade. He exhibited a list of bad debts he had made in the year 1829 , to the amount of $f$ il,180 5s. 9d., and to the amount of $£ 98111$ s. 10d. from the first of January to that day, "and this," said he, "is a pretty commencement for the year 1830." The resolution was earried unanimously. The next resolution enumerated particular instances of unnecessary expenditure, was mored by Mr. B. Grime, sceonded by Mr. Pullein, and earried unanimously. The next resolution, attributing a great portion of the distress to the operation of the corn law, was entrusted to me. I recommended the attentive perusal of Col. Thompson's Corn Lavo Catechism; and proceeded, at greater length than I had ever spoken in public before, to expose the mischierous effects of the landlords' monopoly. In the course of my address, I resolved that the words "radical pariiamentary reform" should, for the first time, ring through that hall. "We see," I said, "the misery that exists around us, and we know that no man, whoever he may be, can deny its existence, unless he happen to be one of those persons who think all are well beeause themselves are well. Why do not members of parliament see this? Because they neither go amongst the people nor represent the people; and allow me to sny," and I said it rery quietly, "that there never will be a proper sympathy for the people until they are represented in parliament,- till there shall be a 
thorough-an effietual-a radical reform." There was here a loul burst of cheering, frequently renewed, each time with additional vehemence, during which the boroughreeve hegged that I would keep to the question. I said, "I have done, sir, but I trust that ere longr we shall have an opportunity of diseussing the question in this hall, for I cannot doubt that the boroughreere and constables, who so readily courened this meeting, if requested by their fellowtownsmen to convene a meeting for the consideration of reform, will readily agree to it." We had not long to wait for the opportunity. The subsequent speakers were Mr. Elijalh Dixon, one of the imprisoned in 1817 ; Mr. W: IIarvey, one of the "small band" of 1815 ; Mr. P. T. Candelet, who had always worked with that band; Mr. J. Whyatt, who said that politics were as much a man's business as his own particular trade; Mr. J. C. Dyer, who was afterwards to do essential service to the cause of political and commercial refurm by his public spirit and close logic ; and Mr. Robert Bunting, who was, as the tory newspaper truly said, "an acute man though no orator."

$\Lambda$ week after this meeting had been held the "Society for the l'reservation of Ancient Footpaths" had occasion to exereise its functions in defence of a public right; and the two events furnished the Guardian newspaper with occasion to animadvert strongly on former friencls who had taken a part in both. Mr. George Jones had built a handsome house at Pendleton, close to a footpath, which he had taken the liberty to divert in order to make space for $\ddot{a}$ lawn in front of his new mansion. The society had protested against the encroachment, and were at first promised alterations, with the view of evading their demands, and then set ut defiance by an insolently couched refusal to do anything. The following aceount of their proceedings is from the Nanchester Times of March 6th :-

"On the afternoon of Monday Mr. Richard Potter, Mr. William Harrey, Mr. W. B. Grime, Mr. R. Bunting, and Mr. Archibald 
Prentice, members of the Footpath Society, proceeded to the ground. On their way they fell in with a person named Murray, an overlooker of Mr. Jones's workmen, and in eonversation with him, had their own previous impression of the exaet eourse of the footway confirmed. Mr. Jones, and Mr. Street, his surveyor, were in waiting, and Mr. Grime was deputed to state to the former the intentions of the socioty. He said that no satisfactory reply haring been giren to their repeated applications, they had resolved to assert the public right, which they felt to be their duty, howerer unpleasant it might be to them personally to seem arrayed against an indiridual. They would, however, he added, earry the resolution of the society into effect in an amicable spirit. Mr. Jones very warmly retorted that he waw nothing amicable in the proceeding. The society, he said, were not satisfied with the public having obtained a better road than he had shut up, and he could therefore only attribute their conduet to private malice and envy. The gentlemen of the society making allowance for the irritation of Mr. Jones's feelings, made little reply to his invectives, and he, probably mistaking the cause of their forbearance, grew still more abusire, and when they reached that part of the carriage road where the opening was to be made in the direction of the old footway, and were making preparations to remove the obstructions, he said the proceeding was most unneighbourly, most malieious, and most ungentlemanly. Mr. Prentice said that these were terms which, under circumstances less irritating to Mr. Jones's foelings, he, for one, would not submit to hear. Very few members of the committee knew Mr. Jones, and some of them probably now oaw him for the first time, and, eonsequently, could hare no malice to him, 'Just to show you, Mr. Jones,' added Mr. Prentice, 'that wo are not actuated by any such feeling, I, who am a stranger to you, will be the first to put my hand to remove your fenee.' II then; assisted by a labourer, who had been brought for the purpose, wrenched out the bolts which conneeted the wrought-iron hurdles that topped the fince, and the workman, with a spade, began to level down the bank, and to make such an opening into the pleasuregrounds as would make the path easily accessible. During this process Mr. Jones, in great irritation, elarged the society with partiality in their operations, in having selected him, while other persons, who had done as he had done, were allowed to escrpe. Mr. Potter begged leave to remind Mr. Jones of the eases against Mr. Wright, of Flixton, against the Duke of Bridgewater, and latoly against Mr. Hall, of Ordsall Lane, and several other persons; 
to show that the socicty, whenerer they had a clear ease, would assert the public rights. The workmen having now levelled down the bank, the deputation walked ncross the grounds directly in front of and close to Mr. Jones's newly-ereeted mansion, making their way through the lately laitl-out shrubberies and flower parterres. Where the footway joised the earriage rond at the other extremity of Mr. Jones's lawn, another bank needed to be levelled, and here again Mr. I'rentice voluntcerel to be the first in remoring the fence, rejeating that no mulice or unneighbourly fecling could possibly influcuee him, who had never spoken to Mr. Jones before, exeept on one oceasion in the Salford Town $\mathrm{Hall}$, where he had experienced snueh courtesy from hin. The socicty, he said, were aetuated solely by a desire to protect the public rights, aud Mr. Jones might rest assured that they would not cease their operations till every footway within twenty miles of Manehester, that had been or should be illegnlly stopped, was opened. Mr. Jones continued, however, to complain of the proceedings, and said, if they must have a footpath, he whould dig one ten feet under the level of his lawn. "No," said Mr. P'rentice, "we will not permit you to do so, Mr. Jones. The public have a riglit to their old footway as it was, and are not to be sent along a deep diteh. The sume law which enables us to open this footway will compel you to make it a good one." The opening having been effected, null men being set to prerent its being again obstrueted, the deputation took their lenve, Mr. Jones assuring them, as they went, that he slowld ismediately apply for a magistrate's order to have the roal diverted."

Mr. Jones, on more deliberate consideration, made application to the Socicty for leave to make such an alteration as would considerably shorten the distance; to which the members, passing over his previous insolence, gavo their consent. But the elitor of the Guardian represented his old friends as disregarding private rights, nnd, connecting the matter with the public mecting, as equally regardless of vested interests. Five letters, each with the name of the writer, appeared in my paper of the 13th. Mr. Shuttleworth replies to an attack on his arguments, and thus conelu'les:-" Regarding the offensive tone of the passage, not as mere rudeness, but as a manifestation of the illregulated temperament which, occasionally sacrificing publie 
interests to party and personal insinuations, bickerings, and contentions, has estranged from the editor his private friends, and sunk and degraded him in public estimation, I cannot, with reference to the forebodings I entertain of its ultimate influence on himself, and on account of the remembrance of past aequaintance and connection, contemplate its present display without the sincerest regret." Mr. W. B. Grime says:- "Nobody but the editor of the Guardian would have had the impudence to assert that the opening this road was a rirtual departure from the objects for which the soeicty was established. Censure from sueh a man is praise." Mr. Thomas Potter says:- "If Mr. Taylor's object be to raise an impression that I, like Mr. Jones, illegally stopped a footpath, he endeavours to make the public believe what he linows to be untrue." Mr. Riehard Potter, in reply to an assertion in the Guardian, that the requisition to eall the public meeting had not been sent to the editors for signature, gives the affilavit of one of his clerks that it was presented to Mr. Jeremiah Giarnett, who said "that there was one point he oljected to, but would consider of it, and if he determined to sign it, would call on Mr. Potter for that purpose," which he did not do. A letter from myself follows, in which I tell Mr. Taylor, in reply to some injurious insinuations, that his repeatedly detected falsehoods had deprivel him of all claim to credenee. It is painful to record these derelictions of principle and ruptures of ancient friendship, but having gratefully acknowledged Mr. Taylor's former services to the publie, I do not see that I should suppress these passages.

There were, as yet, few symptoms of dawn in the politieal horizoi. In the lewislature there was a determined resistance to every proposed reform, however small. A motion for the transference of the East Retford seats to Birmingham was negatived by 126 votes against 99. In the debate Mr. Huskisson alluded to the formation of the first political union:-" He saw in Birmingham lately an 
association which, as far as he could perecive its elements. prineiples, and operations, seemed exactly formed on the model of the Catholie Association; for it had its subseriptions, its meetings, its diseussions, and its agitator. The purpose of this association was to raise a universal ery for parliamentary reform-to carry the question by exaggerating the difficulties, abuses, and distresses of the country. He would rather see the leader of the Birmingham meeting here, as the representative of that town, than in conducting such an assoeiation, sending forth those statements and nppeals to the country, which was, perhaps, too prone, at the present moment, to act on the apprehensions generated by them. Lord John Russell attempted a slight change in the representation by moring for leare to bring in a bill to enable Birmingham, Manehester, and Leeds to return members to parliament. This was resisted-by Huskisson, amongst others-on the ground that such a beginning would lead to wider innovations on the constitution of the country, and endanger the suecession to the throne. Mr. O'Connell noved for a bill to establish universal suffrage, triennial parliaments, and rote by ballot. Lord John Russell moved two resolutions in farour of an inerease in the number of representatives, and for the additional ones being given to large towns and populous counties. The motion and the resolutions were both negatived by large majorities. The tory rule had been shaken, but the whigs had shown little disposition to join the people in their demand for reform. Men looked for a change, but knew not whence it would come. On the 26 th of June George IV died. 


\section{CIIAPTER XXIII.}

\section{SYMPTOMS OF TIIE DAWN.}

There was not mueh grief at the death of George the Fourth-not much joy at the accession of William the Fourth. There was a plain, unaffected, natural man instead of a selfish voluptuary; but William retained Gcorge's ministers, who were disliked by a considerable portion of the community because they had conceded some reforms, and by a still more considerable portion becanse they continued to be opposed to all others. In Manchester therte was a great concourse of persons in the procession on the proclamation of the new king; but the meeting held in the Town Hall, conrened by the boronghreere and constables, to rote an address to his majesty, gave very slight indication of the existence of loyalty, for when the business should have commenced there were not more than twenty persons present. I said it would be a faree to vote an address from such a meeting, upon which Mr. Jereminh Garnett said that he had known meetings of fire or six persons transact very important business. During this conversation the meeting grew into one of about fifty persons, and then the address, which was in the usual strain of condolence and congratulation, was proposed. I moved an address as an amendment, stating that many and grievous evils were endured by his majesty's subjects, from a long course of misgovernment, and a wasteful and extravagant expenditure of the people's money, and praying him to take none into his councils "who would not honestly and zealously enforce the most rigid ceonomy in every department of the public expenditure, and promote the real splendour of the throne, and its legitimate and beneficial 
influence, by the reformation of abuses which are alike derogatory to the sovereign, and offensive, oppressive, and degrading to the people." Mr. Garnett expressed his dislike to politics being introduced into the address, and was supported by a Captain Grimshaw, of whom we shall hear more hereafter, and the voting was twenty-eight for the original motion and twenty-three for mine. An address from twenty-eight persons out of a population of 250,000 was not very complimentary to the new sovereign.

In my paper of July 31 st I find that I said of France: "Royal ordinanecs have dissolved the chamber ere its newly-eleeted members had met, suppressed the liberty of the press, and altered the law of elections. The gorernment of France, which, a few days ago, was a monarchy. kept in eheck by the representatives of the people, is now a simple despotism. If these measures do not produce another revolution, there is a less ardent desire for liberty than we have supposed to exist." The revolution had already taken place. France, in three days, had shaken off the despotism, and the friends of liberty throughout Europe rejoied in her emaneipation, and hailed it as the promise of beneficial changes in every country which was suffering under tyrannical rule. The borougheere and constables Manchester declined to call a meeting of the inhabitants to give public expression to their sentiments on the occasion ; but the meeting, notwithstanding, was held on Monday, the 23rd of August; Mr. Thomas Ilarbottle in the chair. The speakers, amidst enthusiastic cheers from the crowded assemblage, all referred to the necessity of reform at home. "Let us not," said Mr. Mark Philips, soon to be representative of our then unrepresented town, "in our admiration of that glorious burst of freedom which has just been exhibited in France, forget for a single moment that some of our own institutions at home are ineompatible with the spirit of the age; let it not be a reproach to us that whilst France is making rapid strides, England is standing still," 
Mr. Thomas Hopkins said: "Monarchs must now see that it is their interest as well as their duty to move with the people. The great want of the French people has been a real representation, and the sane want is felt in all the nations of Europe." Mr. Richard Potter, who was then making a gallant attempt to open the borough of Wigan, where eertain corporation-made burgesses had usurped the right of roting; which had onee belonged to all the house- . holders, said: "Sure am I that this glorious event will make the boroughmongers of England fear and tremble, and induce the people of Eingland to throw off a yoke which was degrading alike to king and people." Mr. R. H. Greg said that the ministers of our own country would not now dare to support despotism in France. Mr. G. Hadfield hoped that England would so far imitate the example o: France as to insist on reform in parliament, and the abolition of the grinding and iniquitous eorn laws. Mr. J. E. Taylor was scarcely allowed to speak, but his tone was nearly accordant with that of the meeting. Mr. Shuttleworth alluded to the employment by the late French gorernment of mereenaries of other mations. "One of the advantages," he said, " which will result from the change" is, that the Swiss cantons will be deprived of the best market for their detestable commerce in soldiers,-for that foul traffic in the living blood, and bones, and sinews of their population by which those cantons are stained with the deepest disgrace, and human nature itself is insulted and dishonoured." Mr. Edward Baxter trusted that the example of France would not be lost on his own eountrymen, and that Fingland would not be long before she obtained a thorough reform in the House of Commous. Mr. J. C. Dyer said that it had been shown what might be the result when rich and poor formed one common union, in one common effort, for the overthrow of tyranny and the establishment of liberty. The address to the French people was agreed to, and Messrs. Mark Philips, Alexander Kay, 
and Joseph C. Dyer were appointed as a deputation to proceed with it to Paris, where, with Dr. Bowring, the were receired with great distinction by the French gorernment. The electors of the kingdom partook little of the aroused national spirit. In the small boroughs, which sent to parliament a majority of the House of Commons, they were few in number, and almost all dependent or corrupt. Their rulers or purchasers thought the administration too conceding, and members were sent rather to impede than to promote reform. The few large constituencies shared in the prevailing hope that the time was come for some change in that boasted "glorious constitution" which had worked so ill, and, at the general election, Yorkshire re- turned Mr. Brougham, and Middlesex, Mr. Hume. No one could tell how a house so constituted, or a ministry 80 little supported, would act. The newly-elected House of Commons was not to meet till November, and there was an anxious periorl between. In the meantime disturbanees again broke out in the agricultural districts-always the first originators of and sufferers by riot. The much-protected farm labourers made war upon the much-protected farmers, and their kind common protectors, the Iandowners, could do nothing to repress the destructive spirit. Stackyards were blaxing in the dark nights through all the south: castern counties. 'The rick-burning, which commenced in Kent, spread into IIampshire, Wiltshire, Buckinghamshire, Sussex, and surrey. In Birmingham the people took a a different course. They attributed the evils under which they suffererl to misgovernment, and formed a political union to reform the constitution.

In this state of the country, parliament met on the 1st November, und the king's speceh was made next day. In the debate upon the address in the Ilouse of Lords, the Duke of Wellington made a declaration, which did more in stimulating the demand for reform than even the results of the French and Belgian revolutions. His folly may be 
accounted for by the supposition that, after the outery from the bigotted, which followed his coneessions to dissenters and catholics, he was hurriedly eager to assure his party of his determination to coneede no more. Miss Martipeau says his friends imputed his blunder to a deafuess which had been growing upon him, which prevented his hearing what was said by men of his own party. Earl Grey had alluded to the neeessity of parliamentary reform. The Duke, throwing to the winds the Fabian tacties by which he had been distinguished in the Peninsular war,-and observe the iteration and reiteration of the unmisunderstandable deelaration, so often quoted afterwards,-he emphatically said :-

"He had never heard or read of any measure, up to the present moment, which could in any degree satisfy his mind that the state of the representation, conld be improved, or be rendered more satisfactory to the conntry at large than at the present time. Ho was fully convinced that the conntry possessed, at the present moment, a legislature which answered all the good purposes of legislation, and this to a greater degree than any legislature ever answered in any eountry shatever. He would go further, and say, that the legislature and the systcm of representation possessed the full and entive confidence of the country-Drservedux possessed that confidence. He would go still further, and say, that if, at the present moment he had imposed upon him the duty of forming a legislature for any country, and partienlarly for any eountry like this, in possession of great property of rarious descriptions, he did not mean to say he could form such a legislnture as they possessed now, for the nature of man was incapable of reaching such excellence at once, but his grest endeavour would be, to form some description of legislature which would produce the same results. The representation of the people at present contained a large bolly of the property of the country, and in which the landed interest, had a preponderating infuence. Under these cireunistances, he was not prepared to bring forward any measure of the description alluded to by the noble lord. He was not only not prepared, but he would at once declare that, so far as he was conecrued, as long as he held any station in the goveriment of the country, be should always feel it to be his duty to resist such measures when proposed by others." 
Never was the hneknied quotation, quem Deus cult perdere, more quoted than it was now. This was on the 2nd of November; on the $i$ th the Duke increased his unpopularity by advising the king that it was unsafe to entrust himself in the eity; on the 15th Sir IIenry Parnell's motion for a select committee on the eivil list was earried against mipisters by 233 votes ngainst 204 ; on the 16 th the Duke of Wellington and his collengues resigned; on the 22nd Larl Grey's ministry eame into office, and announeed, through their chief, that they would act on the prineiples of peace, retrenchment, and reform, whieh beeame the watchwords during the approaching contest. Time was allowed for the re-clection of members who had accepted offee, and in Deeember parlianent was prorogued to the 3rd of February.

There was time between that 22nd of Nurember and that 3rd of February for the people to think and resolve. In Manchester there were some reformers who placed full ficth in the sincerity of the declaration that peace, retrenchment, and reform, would be promoted. There were others who thought that, cither to support ministers if they were sincere, or to urge them onwards if they were not, it whs desirable to form an associntion ready to act when oceasion required. The ministerial declaration was made on Monday the 22nd; on Wednesday the 24th a crowded meeting was held in the Mechanies' Institution. A Politieal Union was formed, and the following were appointed as the members of its couneil :-

Eli Alkin,

J. Barrow,

George Benthan,

Robert Bubting,

P. T. Cindelet,

James Cox,

Elijuh Dixon,

Jolın Dracup,

Henry lay,

Rowland Detroiser,
John Fielilen,

Robert Froggatt,

Thomas lielden,

l'. Cendel,

Edmund Grundr,

Go. Cirernough,

James IIanpson,

W. T. Heweth,

James II ulme,

Jawes Jones,
Joln Masscy,

Thonas Merry,

William Parr,

Arclibbald Prentice,

Willian Pickering,

Roger Reyner,

Ralph Shaw,

David McWilliams,

Jolın Whyatt,

G. H. Winder. 
With the exception of the Messrs. Fielden, great manufacturers, and Mr. Edmund Grundy, a gentleman of good fortune, retired from business, the council consisted principally of shopkeepers, with a few nen of the working class, but they were men earnest in the eause they had undertaken to promote, and they were afterwards joined by persons of higher eommercial standing. Mr. Wheeler, in his History of Nanchester, says that the Union "never attrined any influence;" but ministers did not think so when they needed its serviees, and the enemies of reform did not think so when they felt its power, not of stimulation, but of repression, for disturbanees with violenee would to them have been very acceptable.

The opening of the Manchester and Liverpool Railway was one of the events of 1830 , which was not without its influenee, in future days, on the progress of public opinion. The auti-corn-law agitation was wonderfully forwarded by quick railway travelling and the penny postage. Even in 1830 the railway promoted the eause of reform. It was an innovation on the old ways of travelling, and a successful one; and people thought that something like this achievement in construetive and mechanieal science might be effected in political science. It brought, besides, a little proprietary borough, which nobody had ever seen before, into full view. I recolleet, when passing over it for the first time, I said to a friend: "Parliamentary reform must follow soon after the opeving of this road. $\Lambda$ million or persons will pass over it in the course of this year, and see that hitherto unseen little village of Newton; and they must be eonvineed of the absurdity of its sending two members to parliament, whilst Manehester sends none."

On Thursday, the 20th of January, 1831, a meeting was held in the Town Hall, to consider the propriety of petitioning for a reform of the representative system. It was ealled by 233 requisitionists, ineluding many of the first merehants, manufacturers, and shopkeepers. The boroughreeve and 
constables had declined to call it, alleging the "cxcitement" that prevailed in the town and neighbourhood as their excuse; their refusil, of course, adding to the excitement. The use of the hall was, however, granted by the police commissioners, and it was filled with a most respectable aulitory. Mr. Edward Baxter, who occupied the chair, inculcated the duty of erery unrepresented locality standing forward, because, if they remained silent, it might be said that they were indiflierent about their rights. Mr. Richard Potter spoke at some length on the necessity of reform, and addueed a number of instanees of the insufficiency and the inequality of representation, and he quoted a statement that had been sent out by me, showing that the parish of unrepresented Manchester contained as many inhabitants as there were in 130 boroughs which returned 260 members, a majority of the Finglish members in the House of Commons. Mr. J. Shuttleworth made an eloquent and effective speech, in the course of which he said: "We are on the eve of a great, a radical change. No other change can be cffected; other means have been tried in abundance and found wanting. Our law books are encumbered with no less than about eighty statutes, regularly made and provicled, as their preambles state, to securc and protect freelom of election, and to jrevent bribery and corruption. And yet, in defiance of this multitude of laws, it is notorions that freedom of election has diminished, and bribery and corruption have increased. To continue patching and bolstering up the old system by additional laws is, therefore, clearly vin and illusory. An entircly new system must be introduced. There is no other mode of redressing present grievanees and averting future. The House of Commons, as now constitutel, is nn assemblage in which the people, whose liouse it ought to be, have no power. The reform nust be such as will return members who will have no interest in misgovernment,-members who will act for the bencfit of the whole community, and not, as hereto- 
fore, for the exclusive benefit of themselves and boroughmongers,-members who will no longer saerifice the interests of the many to the interests of the few." Mr. R. II. Greg showed that in the early periods of our parliamentary history there was a much wider extension of the right of roting than there was now, and that a large measure of reform would be no more than a return to ancient custom. Mr. Thomas Hopkins gave some foreible illustrations of the inequality of representation, and of the excessively heary pressure of taxation. I followed, and argued the neeessity of the reform being either wide, sweeping, and effectual, or such as would give a guarantee of such ultimate result. Mr. Detrosier, a very eloquent young man, who had sought and found knowledge under unusual diffieulties, strongly adroeated the rights of the many. Mr. Mark Philips said, that while unanimity was most desirable, he thought that reform would not be eomplete without the ballot; and Mr. A. Kay urged the necessity of short parliaments. Mr. J. C. Dyer, who had beeome known and appreciated, made an able speech. In referenee to the ballot he said :-

" He had the pleasture to receive, in France, a great many powerful proofs of its efficacy in overturning one of the most gross despotisms that ever aflieted the human race. The ballot, in the hands of only 80,000 electors, orerturned the power of the Bourbons. If these electors liad had to vote openly, in the face of the bayonets of the soldiery, that tyranny would have been established, or the alternative would hare been a most bloody rerolution. The ballot aceomplished the overthrow of that despotisn quietly and effeetnally. In Anerica (where Mr. Dyer was born) he had witnessed the operation of the rote by ballot to a great extent, and at a most stormy time, when the effects of the first Freneh revolution were diriding the world, and causing most nations to girl on the armour of war. The ballot was used without a single soldier requiring to be employed to preserre order; and the electors dicl not ix their choiec upon the low, ignorant, or the violent, but on the most virtuons and talented men the nation possessed."

On Monday, January 31st, a meeting was held in the Town Hall, Salford, Mr. William Hill, boroughreeve, in the 
chair, to consiler the propriety of petitioning that that town should be represented in parliament. The speakers were Mr. John Sinith, Mr. Jerry Lees, Mr. I opkins, Mr. W. Harvey, Mr. Joseph Brotherton, Mr. Lot Gardner, and Mr. J. G. Frost. Resolutions were passed in farour of including the town, as a separate borough, in any measure that might be bronght forwird for parliamentary reform ; and an influential committee, which afterwards sueeeded in its object, was appointed to carry the resolutions into effect.

Amidst the cheering hopes of reform, and the active demonstrations to secure it, there was much to throw gloom on the commencement of 1831. Two special commissioners had been appointed to try the prisoners who had been upprehended during the rick-burning disturbances, not yet fully prevented. These commissions were opened at Winchester on the 20th, and at Reading on the 27th December, and proceeded to Wiitshire, Dorsetshire, Buckinghumshire, and other counties. The list of convietions and sentences is a melimeholy one. On the 9th of January, judgment of death was recorded against twenty-three prisoners, for the destruetion of a paper machine in Buckinghamshire; in Dorset, on the 11th, against three for extorting money, and two for robbery; at Norwich, fifty-five prisoners were convicted of machinebreaking and rioting; at Ipswich, threc for extorting money; at Petworth, twenty-six for machine-breaking and rioting; at Gloueester, upwards of thirty; at Oxford, twentynine; and at Winchester, out of upwards of forty convicted, six were left for exceution. Four of these were afterwards respited; but two of then were executed on the 15th. At Salisbury, forty-four prisoners were convieted, of whom two were executed on the 25th. In the whole, upwards of eight hundred of the rioters were tried before the commission; and all of those who were convieted, with the exception of the four cases mentioned, were senteneed to various terms of transportation and im- 
prisonment. Sad commencement this for the year of hope. In the great manufacturing districts there was no rioting; the people there better knew the causes of their distress.

Parliament was opened on the 3rd of February. On the first day of the session Earl Grey stated that "ministers had suceeded in framing a measure which, they were persuaded, would prove efficient, without exceeding the bounds of that wise moderation with which such a measure should be accompanied. Lord John Russell made a similar notification to the House of Commons. It was not until the 1st of March that the ministerial plan of reform was explained, the nation in the meantime waiting the disclosure with great impatience. The measure was quite as broad and effective as the people expected-bronder than was expected by those who doubted whig sincerity and courage. My comment upon it was :- "Our readers know that wo are advocates of the broadest possible suffrage, of the annual exercise of the elective right, and of the protection afforded to the electors by secret roting; and that, consequently, no scheme of reform which does not embrace all these points, can receive our unqualified approbation; but we nerer allowed our wishes so far to get the better of our judgment as to suppose that we should have a perfect system of representation all at once. Wo have looked forward to a prolonged contest, in which we should gain a little now, and a little then, and thus be enabled to take fresh ground, and to press forward till complete victory was obtained. We did not, of course, expect that even the most zealously reforming administration, considering the strength of adverse interests which would have to be encountered, would venture to propose anything like a perfect scheine. We have it now before us, and though it falls far short of what we demand, and what we believe we shall ultimately, and at no rery distant period, obtain, it is a great deal better than we expected, and ministers have our most hearty thanks for it, and they shall have 
our strenuous support to carry it into effect, should the boroughmongers, as it is probable they will, foree them to appeal to the country." I belicve that such were the opinions, throughout the country, of the class of persons who professed rational radicalism, as distinguished from the radicalism which would have all or nothing.

After a debate which was prolonged for seven days, the motion for leave to bring in the bill was agreed to without a division. The utmost excitement, during this tardy progress, was manifested in the country. On Wednesday, the 9th of Mareh, a meeting, to thank minişters, was held in the Town Hall, Manchester, called by the boroughreeve and constables-the first they had called on the subject of parliamentary reform-and many were present who never before hitd taken any part in the morement. But it had now the sanction of the whig administration, and, it was believed, of the whig aristocracy generally. Not many new speakers, however, had yet appeared. The chair having been taken by the boroughreeve, Mr. James Burt, the meeting was addressed by Mr. Richard Potter, who drew a strong contuast between Mr. Peel's opposition to the disfranchisement of votes in English rotten boroughs, and his former haste to disfrunchise the whole of the Irish fortyshilling freeholders. Mr. E. Baxter asked whether, if the king had the power to confer seats, he would seleet the village of Newton or the great town of Manchester? Mr. Mark Philips made a spirited speech, in which he called on the county not to waste its power in a skirmish of out-posts, but to concentrate its strength and bear down upon the corruptionists in one united and overwhelming mass. Mr. John Shuttleworth spoke with great eloquence and effect. Mr. R. H. Greg said, contrasting Charles $\mathbf{X}$ and William IV, he had often heard of the revolutionary spirit of the people, but he thought those complaints might be retorted on the sovereigns. Mr. George Hadfield, an early and decided reformer, but who had not taken much part in 
public meetings, quoted Mr. Pitt's saying, that no honest man could be minister, in his time, as the house was constituted, and said that its truth was as obvious now as it was then. The eloquent Detrosier again asserted the right of the over-taxed, corn-law-oppressed poor to representation. Mr. E. J. Loyd, one of the 1688 whigs, expressed his gratitude to the administration. Mr. James Wood, who afterwards recommended MIr. II. II. Birley as a fit member for Manchester, said he had travelled all night to have the pleasure of attending the meeting. Mr. Absalom Watkin spoke briefly but energetically. Mr. G. W. Wood, another 1688 whig, said he heartily joined in the resolution of thanks to ministers. Mr. J. C. Dyer, Mr. 'Thomas Potter, and Mr. Alexander Kay spoke briefly but emphatically; and the rote of thanks was passed unanimously.

A little episode in the proceedings showed the jealousy with which recent converts were received, when there was a belief that their conversion was with a view to future favours from the new eonstitucncies. $\Lambda$ motion had been made that the petition to the lords should be presented by Earl Grey, and that to the conmons by Lord Althorp. Mr. G. W. Wood, said he would prefer its being presented by Lord Stanley and Mr. Wilson Patten, members for the county, who had been very attentive to the deputation sent to London to obtain the repeal of the calico-print duties. Some one asked if Mr. P'atten was a reformer. Mr. Wcod said he did not know; but it was desirable that he should be one, and he hoped their confidenee would make him one. Mr. Thomas Potter said it was a piece of great presumption in Mr. Wood to find fault with the arrangements of the committee. I protested against bribing any one with confidence before he had earned it. The time was coming when they would not need to bribe men to be reformers. The time was come when those who wished, like Mr. Wood, to be thought reformers, should come forward and join the ranks of the reformers. To Lord Stanley, and Mr. Wood, 
and Mr. Wood's junto the police commissioners owed their banishment from that hall. Mr. Wood attempted to reply, but the meeting would not permit him. Mr. Shuttleworth said he hoped the boroughreere would allow nothing but explanation, for, otherwise, MIr. Wood would continue addressing then until the sun set. Mr. Wood was at length permitted to say that he gave an unqualified denial to $\mathbf{M r}$. Prentice's statement, to which Mr. Prentice said he could prove it, and that Lord John Russell had, some few years ago, been deceived by the committee of which Mr. Wood was a member into the belief that a $\mathfrak{£ 2 0}$ qualification would be acceptable to the people of Manchester.

On the 1 th of Marel the bill was read a first time. On the 20th the second reading was proposed, and carried by a majority of oxe, in the fullest house ever known to have vivided, the numbers being, 302 for the motion, and 301 against it. This narrow majority - this almost lost sanetion of the honse-inereased the excitement of the country, which sliowed that the promised reform, or the mutilation of the "bill," would not be quietly submitted to. The obstruetires, however, dared all the cousequences. On the 18th of April the house went into committee, when a motion was made by General Gascoyne to the effect, that the number of members for England and Wales ought not to be diminished, and tho house divided with a majority of eight against ministers. This was virtually to save a number of the retten boroughs, and to deny to Scotland and Ireland the increased proportion. of members to which they were entitled. Ministers tendered their resignation to the king, but it was declined. On the Wednesday night, or rather on 'Thursday morning, they were again deieated, when Mr. Banks moved an adjournment, and obtained a majority of twenty-two, thus refusing to go into the question of supply which should hare occupied the house. The king was now appealed to, and he resolved to dissolve parliament. Miss Martineau gives a graphic account of the 
scene between his Majesty and Farl Grey, with one or two of his colleagues. "He was yielding-had yielded-but with strong expressions of reluctince, when that reluctance was suddenly changed into alacrity by the news which was brought him of the tone used in the House of Lords about the impossibility of his actually dissolving parliament, undoubted as was his constitutional power to do so. "What! Did they dare to meddle with his prerogative?' the king exclaimed; he would presently show them what he could and would do. He had given his promise; and now he would lose no time; he would go instantly-that very moment-and dissolve parlinment. ' $\Lambda$ s soon as the royal carriage could be got ready,' his ministers agreed. 'Never mind the carriage-send for a hackney coach,' replied the king-a saying which spread over the kingdom, and much enhaneed his popularity for the moment."

I was in London at the time, and had been told in the morning by Mr. John Wood, member for Preston, that the house would probably be dissolved that day. I had come from Jeremy Bentham's house, through St. James's Park, and through the Horse Guards, to see what might happen; and there was the king on his way, with a guard of cavalry, riding wide of his carriage on ejch side, not preventing persons from eoning close up to him. One rough sailor-looking man rushed to the side of the carriage, pulled off his hat, waved it round his head, und shouted, "Turn the rogues out your majesty," and his majesty had an air of determination on his countenanee which declared that he meant as much, and without ceremony. In the midst of a hot wringle in the IIouse of Lords on the prerogative of the king, the sound of eannon announeed his approach. There was n ery of "the king, the king." Lord Mansfield was, amidst the confusion, protesting against the conduct of ministers in " conspiring together agninst the state, and of making the sovereign the instrument of his own destruction," when the king appeared, and the com- 
mons were summoned, and drawn from an equally exciting scene in their own house. The king began in a dignified and determined voice, and ended thus:- I have come to weet you for the purpose of proroguing this parliament, with a view to its immeliate dissolution. I have been indueed to resort to this measure, for the purpose of ascertaining the sense of my people in the eireumstanees of the country, in the way in which it can most constitutionally and most anthentieally be expressed, on the expediency of making such ehanges in the representation as circumstances may appear to require, and which, founded upon the acknowledged principles of the constitution, may tend to uphold the just rights and prerogatives of the crown, and to give security to the liberties of the people. * * * In resolving to recur to the sense of my people, in the present circumstances of the country, I have been influenced only by a parental auxiety for the contentment and happiness of my subjects, to promote which, I rely, with confidence on your continued and zealous assistance." A proclamation, declaring the dissolution of the parliament, appeared next day, and the new writs were made returnable on the 14th of June, 


\section{CIIPTER XXIV.}

BECOLLECTIONS OF JEREMY BEXTIIAM.-THE ACTHOR'S TRIAL FOR LIBEL.

MY visit to London, at this important crisis, brought me into friendly communication with a man whom $I$ had long honoured. I had long beld the name of Bentham in high veneration. His writings had been my political text books, and, as he had been an author nearly twenty years before $I$ was born, my first impressions of them were as precious legacies from the mighty dead, rather than as the productions of a contemporary. When I had taken my station in the ranks of those who were combatting for reform, and, as I believed had been instrumental in popularising some of his doctrines, and thereby rendering them, in my comparatively narrow sphere, the guiding principles of many ardent friends of liberty, my feeling of reverence for the great apostle of reform did not wear off; for I'heard of him as an aged recluse, oceupying in useful labours the short time that might still be allotted to him, after having lived a dozen years beyond the "few and evil" days which the Psalmist has assigned to man; measuring out his remaining minutes in works for the promotion of " the greatest happiness;" seeing none but men, who, from their talents or station, were likely to carry his prineiples into practical operation; and never stirring beyond his threshold but to take his accustomed circungyrations in a garden which had been Milton's, and therefore, in itself, an object exciting elevated and spirit-stirring associations in the mind of every admirer of high intellect and lover of freedom. With such an estimation of Bentham, and not daring to hope that I should ever be admitted to any communication with tho 
venerable jurist, it may be imagrined with what exultation I read on the title-page of a book sent me (the first volume of his Constitutional (ode) my own name neitly inseribed, with the adclition of "from Jeremy Bentham. Q. S. P. 11 th of April, 1831." I know not if any lover erer read with more delight the first epistle from his mistress than I did the note accompranying the present, in which I found myself recognised as a fellow-labourer with him " in the field of parliamentary reform-in the vineyard of law reform-in the field of veracity and justice." $\Lambda$ s I had to be in Loulon in a week or ten diys, I delayed to answer certain queries he hanl put to me, in the hope that, should I fiul no friend having the privilere of admission to the venerable jurist, I might have the greater chamee of being allowerl un minute or two in his presence. Colonel Thompson ancl Dr. Bowring, from whom I could ask for an introduction, were both absent. In this difficulty I put a bold face upon the matter, went right off to Quecu-square Place, pulled the bell, my heart palpitating the while, and presented uny eard. I was not kept long in suspense. The servant returning almost immediately, said Mr. Bentham would be with me in a few miuntes.

'The walls of the room into which I was shown were covered with a elark-colomed Inlian paper, seemingly as ancient as its owner, with strange birds of the size of pheasants, represented as sented on the branches of vine-like stems, with leaves anonymous to the botanist, and flowers as yet mondescript. 'The chairs and a large book-ease were of the kime date, dark and massive, and on a table stood

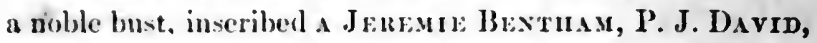
with the mo:to, " puerimomu Maxima Felicitas." Amomerst the newspapers that lay upon the table was one in French. printed at New Orleans, eontaning a notice of the adoption of some of Bututhum's " Collifications" by one of the soum American republies, and I was deep in the mildle of this when the door opened and the venerable 
sage, his long silvery hair hanging down on his shoulders, and his fine features, still fresh and florid, beaming with benevolence, appeared before me. All doubt about the nature of $\mathrm{my}$ reception was at once dispelled, for he approached me holding out both hands and exelaiming, " $\mathrm{Ah}$, I nm glad, very glad to sce you. I expected you to write, but I am much better pleased that you have come to see me." After a short conversation he invited me to accompany him in his daily walk round the garden, and there I accommodated my pace to his quick short shuffle, and we held converse on the promotion of the greatest happiness of the greatest number. It was enough to walk in the garden of the patriot poet with the patriot jurist, but I felt it as an additional gratification that I was enabled to tell him I had good reason to believe than an ancestor of my own, the right-band man of Lockhart, the parliamentary general, had there often discoursed withe the author of the Defensio pro Populo. When I conceived that I was about to take my leare, probably for ever, of the ared reformer, at the little gate that opened into St. James's Park, he said, "You must not leare London without having a social chat with me," and invited me to dine with him next duy. A " social chat" with Bentham! To fill up the measure of that day's enjoyment, I had not been five minutes ubsent from him before I saw the king hurrying down to the House of Lords to do that which never English sovereign had done before-to dissolve $\mathfrak{a}$ parliament beeause it was adverse to reform. It seemed to me that the seed had been sown in good ground and that it was bringing forth fruit abundantly. If in the reign of that sovercign the produce was thirty-fold, may it be a hundred-fold in the reign of our youthful Queen.

Inalf-past seren o'clock next evening found me sitting at a neatly set out and recherché dinner in Bentham s library, the single French lamp shedding its broad light on the table, but leaving the books which lined the walls in a 
darkness risible. We sat on a platform raised about three fect from the floor, and extending to within about three feet of the wall on each side. The space between the floor and the platform I found was intended as a well to contain hot air-a Russian mode of heating apartments, recommended by lientham's brother, Sir Samucl. The conversation of my host was light and playful, but full of vigour, beautifully combining the wisdom of the sage and the simplicity and gaiety of the ehild. I expressed the pleasure I felt in observing that adruneed years had not impaired his eheerfulness. "Sir," said he, "I eultivate cheerfulness as a habit. Besiles, I have the consciousness of haring for sixty years endearoured to promote the happiness of $\mathrm{my}$ fellow men, and why should I be otherwise than cheerful ?"

The period of my visit was one of high hope. A great principle had been asserted, and all believed that it was soon to be carried effectually into practice. The nation exulted in the expectation of a great reform of the representative system, and already were men's minds directed to the menus of securing the fruits of that onward morement, and the character of many who were likely to take a prominent part in the subsequent contests was strictly serutinized. Bentham, at eighty-two, had the confiding faith of a lad of sixteen, and unreservedly spoke of all of whom I asked his opinion, either as leading statesmen or as the probable representatives of new or reformed constituencies. Of one distinguished by great and versatile talent, he said:- "I never knew whether he was in jest or earnest. II comes here and tells me he has come to sit at the feet of Gamaliel and imbibe wisdom from my lips but when I begin to show him that his projected legal reforms have no simplicity or breadth of principle, he suddenly discovers that it is time to go away to dine with my lord this or my lady that, and I see no more of him for a month, when he comes again with the same story that he is secking wisdom from the Gamaliel of the law, and again 
he runs away so soon as I begin to show that his reforms are only poor palliatires of a system essentially bad." Of a prominent member of the commons he said :- "I think he confounds low-priced government with cheap government. What we want is good government. However, he does his part by endearouring to cut off the springs of corruption."

We tulked much of his friend, Dr. Bowring. He said it was a great mistake to suppose that Bowring's literature unfitted him for practical business, for he was well acquainted with all the bearings of eommeree, and there was not a man in the kingdom more able to simplify and methodise the public accounts, the complexity of which seemed purposely contrived to conecal frauds and keep the country ignorant of its financial condition. "You," said he, " are practically acquainted with trade, and you shall judge of his knowledge of it. Here is a pamphlet written by him Beveral years ago, from some very meagre notes of mine. Pray glance your eyes over it while I take a little exercise." I found the work contained a very lucid view of our commercial relations with Spain, and that the doetrines of free trade were vindieated with statesman-like ability. When I had finished my reading I looked around for my venerable host, but he had disappeared. My attention, however, was directed to something white, waving backwards and forwards in the dark space between the raised platform on which I sat and the book shelves. It was the silver hair of the octogenarian, who having poised himself on both hands and lifted up his feet, was swaying his body with all the rigour of one of the pupils in his own gymnastic school. This was his evening's cxercise, as the walk round Milton's garden was his exercise of the morning.

Our conversation resumed ; we went back to the days of the "Club," Nr. Johnson's corn-law tract being the train of association. Bentliam had dined with some of the fraternity onc day, and observing that Boswell had inade some 
excuse to go baek to the dining room when the party were on their way to the drawing room, and having some suspicion that the excuse was not the real one, he turned back and wickedly detected Boswell in the act of swallowing glassful ufter glassful, hastily poured out from the bottoms of the decanters, of sundry varieties of wine that stood on the table, under the influcnee of which, when he joined the ladies, the biographer of Johnson became as eloquent as, according to his own account, he had ever been, under similar influence, in the presence of the Duchess of Argyle. I amused Bentham by telling him how Boswell's father, on one oceasion, had combined frugality with generosity. My great-uncle had been tutor to James, and Lord Auchinleck, more Scotorm, had rewarded him with a kirk, a cheap way of repaying fumily obligation. When my relative was about to be married, the old whig lord was told by one of his friends that he ought to make the minister a present of some plate, but unwilling to lay out moncy, he took a do\%en silver spoons from the family store, with the fumily initials upon them, and had the tail of the $\mathrm{B}$ altered, so as to convert it into a tolerably decent $R$, the initial of his son's instruetor, and these, with half a dozen small mugs of the same metal, and similarly re-inscribed, were presented in form. 'The plate is now in possession of my brother, and the alteration is very obvions.

Bentham had never any sympathy with the politicians who were active from other motives than those which arose from an enlightened benerolence, and therefore he did not like Horne 'Tooke. " John Horne," said he, " was present one day where I was at dinner, and his amusement was in teazing two American gentlemen by sareasms on their country, conveyed not so broadly as to justify their showing any resentment, but obviously giving them pain. I cannot understand how any man can have plensure in giving pain to another." Nor could he, for, both from natural disposition and principle, no man was more attentive to the 
amenities of life than Bentham. He cultivated benerolence as he did cheerfulness.

A friend who held Bentham in great veneration was with me in London, and when I left him in the erening had earnestly and solemnly conjured me, by the remembrance of a twenty years' friendship, that I should procure him something from Bentham, were it even his smallest pamphlet, with his hand-writing in it. I had teazed my friend a little, saying that $I$ could not presume to take such a liberty with a man so much beyond my intellectual rank; and, half angry at my affeeted fastidiousness, he muttered something about Seotch coldness and caution. I laughingly told Bentham of this, and taking down one of his volumes, he carefully seleeted the best of his pens and said, "I know him as a good friend of liberty, and as usefully engaged in making good books eleap;" and I delighted my friend next morning, after maliciously keeping him some time in suspense, by showing him the book and the carefully and neatly written inseription-"John Childs, Esq., from Jeremy Bentham."

From the subject of instruction of the young, which wns introduced by the presentation of a little tract I had published on schools for infants, we went by a natural transition to the instruction of nations. Bentham had been reading Kotzebue's strictures on the eonduet of the missionaries in the South Sea Islands, and he expressed his fears that the inhabitants had only exehanged one abject superstition for another, and that no advanee would be made in eivilization under the usurped dominion of ignorant fanatics. I thought it but justice to remove from the mind of such a man his misapprehension of the eharacter of the enlightened and devoted missionaries, who had made Christianity the precursor of a rapid civilization ; and I told him of the cessation of human sacrifices and infantieide, the institution of marriage, the appointment of magistrates by the voice of the people, the adoption of a simple code of 
laws-such as he himself might have recommended, the establishment of a printing press, the encouragement of agriculture, and the introduction of commerce and the useful arts. He was execedingly interested with the detail, and learning that my authority was Mr. Ellis's book, bo called his secretary, a young gentleman whom he addressed with the affectionate kindness of a father, and requested him to purchase it for him in the morning. It was now half-past twelve, and I took my leare of the renerable old man, with a bundle of his books which he had presented to me, having first reecived a cordial invitation to visit him whenerer I came to London. "My time," said he, "is but short, and I cannot have many opportunities of seeing you." I saw him only once again. The oil was fast wasting in the lamp which had burned so long and so brightly. He died on the day before the Reform Bill passed, and he knew that it was to pass.

Before my return home a "true bill" for libel was found against me, at our quarter sessions. I procured a copy of the indictment, and learned that I, "Arehibald Prentice, late of Manchester, labourer," being a person of a wicked disposition, and instigated by the devil, had, with foree and arms, printed, and cansed to be printed, published, and caused to be published, certain false, scandalous, and malicious things, therein set forth, of and concerning one John Grimslaw, commouly called Capt. Grimshaw. What I had said was as true as holy writ, but, aceording to judge-made law, no doubt a libel. I had said he had been accustomed to gire indecent toasts at publie dinners, and everybody knew that he had. I resolved to deny the tenability of an indictment calling upon the jury, upon their oaths, without other evidence than proof of publication, to find that I was guilty of the malice and falsehoorl charged; but having some faint reeollection of having seen something in print by Bentham upon the law of libel, I sent Dr. Bowring a copy of the indietment, begging lim to lay it before his 
illustrious friend, and to ask him what course I ought to pursue. In the eourse of a few days I reeeired a pamphlet published by him in 1817, denying the tenability of such indictments. In a few days more he sent me an examination of the indictment, exposing its absurdities and falsehoods, and arguing that a jury could not, without perjury, find that to be false which was not proved to be false. I was of course delighted with haring a corroboration of my opinion from such a quarter; and as it was not likely that I should find a lawyer bold enough to set the dieta of the courts at defiance, I determined to undertake my own defence. The trial came on at the Manchester quarter sessions, July 14th, and it became my turn to address the jury. I arose, not without some embarrassment, for it was a new scene to me, and there were fine and imprisonment, at the mercy of the court which I was defying, if I failed. But there was something in the novelty of the argument, and the plainness and earnestness with which it was offered, that strongly arrested the attention of the jury. In the indietment I had been called a labourer, and I said, in the words of Bentham: "Yes! a labourer I am in a certain sense, and I glory in 80 being. $A$ labourer $I$ am, and a labourer $I$ have long been, in the field of parliamentary reform; and for my labour in that field, rather than from any injury to Captain Grim. shaw, I suspect I owe my appearance before you to-day. A labourer I am, as you see and hear, in the vineyard of law reform-in the field of veracity and justice." I had been charged, in the indictment, with malice and falsehood, and I asked the jury: "Can you, upon your oaths, declare that to be false, of the falsehood of which you have not one particle of eridence, and the truth of which you shall henr me offer to prove? Will you, on your oaths, deelare that I have published a FALse libel? I know that you will not. I cannot imagine the possibility of there being, amongst twelve respectable and intelligent men, one who would upon his oath declare that to be false, of the falsehood of 
which there is not only no eridence, but not the pretence of evidence, while of its truth evidence is tendered and refused." I went on to examine count after count of the indictment : "Count the fifth is the same as count the first and fourth, but with this very remarkable difference, that the word 'false' is omitted. 'True or false as the libel might prove, here is a trap laid for you to convict me. The indictment-drawing attorney has anticipated my objection, though the learned counsel has not. He has contemplated the possibility of an honest jury being unwilling to declare that to be false which, for anything he knew to the contrary, might be as true as holy writ. But 'vaulting cunning doth o'erleap itself.' 'The very leaving out of the charge of falsehood is an express acknowleclgment that the charge itself is false. Here you have them demanding of you that you shall punish me for speaking the truth: and will you forget the ancient law of the land, and so confound the distinctions between right and wrong as to expose me to the same punishment for speaking the truth as would be awarded to me if $I$ had been guilty of the most atrocious falsehoods." I asked the chairman, Mr. Norris, if I might be allowed to prove the truth of what $I$ had asserted conrerning Grimshaw.

"The ChairMas.-Certainly not.

"Mr. Prestick-I have witnesses in court to prove the whole of what I have asserted; but I am not allowed to call them. But my case is complete without them. A man who is eharged with an offence in a court of justice is not called to prove the falsehood of the eharge. It must be brought home to him by eridenee. If there is not proof against him there is nothing for him to rebut, and the elarge falls to the ground, as this must."

I went on to say that eren had I eharged Grimshaw with the utmost wickedness that human nature can reach: "even, in such a case, I should have been entitled to a verdict of not guilty, for you could not have subscribed to all that is contained in this indictment; and, as I said before, if a criminal escaped in consequence of your 
sentence of acquittal, the fault would not lie with you, . but with the blunderer who erammed his indietment with statements unsupported by proof." And thus I went on, for an hour, repeating, in a variety of forms, nearly the same things, and coneluded by saying:-

"Gentlemen, I deny that I have written any libel on Captain Grimshaw that calls for punishment; but if I had, dare you, upon your oaths, declare it to be either a false or malieious libel, without one particle of proof either of falsehood or malice, and not only without proof, but in the face of my offer to prove the contrary? I opeak boldly, gentlemen-you cannot. As honest men you cannot. As Christians, retereneing the sacred oath you have taken, you DARE NOT. I have not appealed to your passions, gentlemen, but I do appeal to your understandings, which are mocked by this indietment-and I do appeal to your consciences, which are insulted by this indietment, and $I$ call upon you to regard your verdict not as a matter between the lawyers and you, but as matter between you and your GoD, - and to give such decision as you shall answer for in the great day of judgment, in that eourt where it will be in rain to plead custom as an exeusc for the rIOLATION OP AN OATH."

The chairman of the sessions had the usual reply in such cases:- "The law says if any one personates or writes for publication, concerning any individual or individuals, that which has a tendency to bring any person into hatred or contempt, such writing or personation is a libel; whether the writer intended it should have that effeet or not, still it is a libel, and, being so, the law presumes that it is false; and the inference is also that it is malieious, and the law presumes that it is both malicious and seandalous so to bring any one into contempt. A libel, having a tendeney to excite to a breach of the peace, was said to be against the peace of the king; and it was a customary thing, therefore, to say it was done with foree and arms."

Immediately after the chairman had coneluded his charge, a little after seven o'clock in the evening, the trial haring lasted two hours, the jury requested permission to retire for the purpose of considering their verdiet; and after one 
of the police-officers had been sworn in charge of them, they were conducted to the grand jury room, there to remain without food, fire, or candle, till they agreed upon. their verdiet. The court sat still for two hours without calling any other ease. At nine o'clock there being no tidings of the jury, the chairman sent for them, and asked them if there was any probability of their soon coming to an agreement? The foreman very emphatically said they were not likely, and they were then sent again into their room, and the court was adjourned to Mr. Norris's house, where he sail he would receive the verdict at any hour of the night. I remained at Mr. John Whyatt's, in Bridgestreet, expeeting, throughout the whole of the night, to be called on to aceompany the jury to Mr. Norris's house; but hour after hour rolled on, and still the jury remained. At six in the morning we went to look up to the windows of the grand jury room where they were in durance, but still there was no indieation of morement. The court opened at nine next morning, and still the jury were locked up. An appeal ease was entered upon and concluded without any tidings from them. At a quarter to eleven, ffteen hours and a half from the time they had retired, Mr. Brandt rose, and said, that after the long period the jury had been locked up, he was willing to prevent their suffering any further confinement, and would consent to their being discharged if they were still unable to agree. The Chairman: "Do you consent to this arrangement, Mr. Prentice ?" I said, "I do, most willingly. I have no desre to prolong their eaptivity." The jury were then ealled in, and on saying that they still were unable to agree, they were told of the arrangement, and discharged.

It was afterwards stated by some of the jurymen that TEx of their number decided on a verdict of "not guilty" in a few minutes after they retired. The forcman, they said, was for a verdiet of guilty, and that another joined him, on condition that if the verdict were "guilty," it 
should be aecompanied by a declaration that the falsehood had not been proved. The TEN, howerer, were inflexible. One of them had laid himself down, at full length on the table. Another asked him, "Hast thou a bowster (bolster) there?" The reply was: "No, I have no bowster but the bowster of God's truth and justice, and I winno' bring in this man guilty." Another, who had lost his right arm in his youth, held up the other and said: "I will gnaw the flesh from the bones of this one arm before I find him guilty." They had all found the sensation of thirst very painfully, and when daylight eame they looked out wishfully upon the Irwell flowing past, black as ink, thinking it was a great pity that so much good water should run to waste whilst they were so dry! Here are their names :-

George Jackson, foreman ..................... Salford

William Dixon .................................. Do.

Thomas Bainbridge ........................... Do.

John Fleteher ................... Wuerdle and Wardle.

William Crossley .......................... Todmorden.

William Scholfield .......................... Do.

Robert Barker ........................... Tottington.

Richard Howarth ........................ Do.

Thomas Elton ............................ Do.

John Wilde ............................... Do.

Edmund Piekup .......................... Do.

John Priestley .............................. Do.

Many of the London papers reported and commented upon the trial. The Examiner paid me the eompliment of attributing, from internal evidenee, but erroneously, a partieular part of $\mathrm{my}$ speech to the pen of Benthan. Cobbett, who had been tried a week before, and escaped the conviction that was earnestly desired, expressed himsclf exultingly at this another triumph over the judgemade law of libel. I had written to Bentham, asking him to felicitate me on the result, and the following was his reply; which will be found also in Bowring's Memoirs of the Jurist's Life:- 
"Qucen's Square Place, Westminster, July 21st, 1831.

Dear SIR,-Yes; I do felicitate you; I felieitate the honest and intelligent jurymen, I felieitate the country in general, I felicitate myself, on this your virt usl aequittal. I say the country in general; for further, much further than to the deliverance of one innocent nam from the persecution under whieh he was suffering, do I look for the benefit cupable of resulting from this erent. It not only always lus been, but will now be very extensively seen to be, in the power, not merely of any jury, but of any one unan in any jury, to effect no ineonsiderable progress in the eareer of law reform. For produeing an effect so eminently desirable, a rery few juries, and thence a very few individuals, one in each jury, will suffice. Choosing for the experinent those cases in which the acquittal, though of a person by whom the offence has really been committed, will be pro. ductive of least evil to the public (and many are the cases in which it would not be productive of any eril at all); making this choice, and declaring that the acquittal had no other cause than their determination not to join with the judges and their partners in iniquity, in the contamination of the publie morals, by the utterance of such a tissue of solemn and pernicious falsehoods, it will be in the power of this small number of individuals to eompel those on whom it depends to clear all instruments of accusation from the greater part of that mass of pickpoeket lies and absurdities with which they have hitherto been loaded. This may a small number of the lovers of justice do; and thus doing, they will thus pare the way for the establishment of that all-comprehensire plan of law reform to the organization of which nearer three-quarters than half a century of my life has been devoted. And here, sir, you have before you my ground for selffelicitation.

"The course which I am thus using my endeavours to recommend to jurymen is no other than that which I myself would take were I in their place. In former days it happened to me to be summoned to serve upon juries of both kinds, grand and special. Haring receired from nature the experieneed faculty of remaining without food for several days without much ineonrenience, it would have been in any power in the situation of juryman to eommand the rerdict; and if so disposed, in the situation of member of a petty jury, special or common, to give or sell impunity for any crime at plesaure not to speak of the giring to one man the property, to any amount of any other. With what feelings and what riews I figured to inşelf this power in some hands, I leave you to imagine. On the 
particular occasions then in question, I saw no prospect of rendering to my country in a jury box service to so great an amount as it coemed to me I could render, and was actually rendering in my closet, and thence it was that the invitation nerer experienced my scceptance.

"' 'Of a bad bargain make the best,' says one of our old saves, nor that the least instructive one. Under the rotten and anti-popular constitution, for the change of which into a sound and popular one all ejes are looking with such intense anxicty, the main use of juries, as at present constituted, is, my view of the matter, the veto which the institution gives to the people upon laws-upon bad laws in general, and in particular upon all those in which the oligarchy by whom we are plundered and oppressed have a special sinister interest.

"On a cursory glance, it does not seem to me that you had reason to complain, either of the learned gentleman who led as counsel mainst you, or of the other learned gentleman who on this occasion officiated as judge. Thus the law is, says the judge; and in saying it, says what is but too true. Thus the law is-that is the spurious, judge-made law-substituted to legislature-made law and to parliament-made law, and in this consists the grierance.

" As to the learned counsel, 'Mischief is capable of being done,' says he, "by taunting men with offences which they have really committed.' In this (though it would not come up to his purpose by warranting the jury to tell the lies in question) there is unquestionable truth, and it presents a real demand for regulation. Such regulation my penal code would accordingly give; but of judge-made law (if to the tissue of irregularities which have no words belonging to them the name of law must be misapplied), one of the evil properties is, that by it no regulation of anything can be made.

"It is with no small satisfaction and admiration that $I$ have observed the ability with which you turned to account the materials with which $I$ had the pleasure of furnishing you, and the important additions which you made to them.

" Dear sir, yours sincerely, "JEREMY BENTIIAM."

"Anchibald Prentice, Esq., Manchester."

"P.S. My adrice to jurymen is plain and unmisunderstandable, and nothing can be easier than to follow it. Examine the indictment, and if in any part there be any assertion that is either notoriously falso or not proved to be true, do not join in declaring it to be true, but say 'Not Guilty.'" 


\section{CHAPTER XXV.}

THE DELEG TE PARLIAMENT.

For once, there was an " appeal to the country;" all other so-named appeals, in our modern history, had been to the rotten boroughs and the close counties. The popular will bore almost universal sway. The election cry was "The bill, the whole bill, and nothing but the bill"- - the meaning of the latter condition being "nothing less than the bill." The conviction had spread amongst the enemies of reform that, if there was not change to the extent promised, reform to a much greater extent would be imperatively demanded. They yielded to what seemed to be an ineritable necessity; and the curious spectacle was exhibited of rotten boroughs sending delegates to rote for their own disfranchisement. A stand was made in the universities, and in boroughs where the tory aristocracy had unlimited power; but wherever there was more than a mere shadow of representation, men were elected whose sole pledge was that they should pass the bill. There was to be a convention of 1831 , as there had been a conrention in 1688-a convention, not to alter the succession to the throne, but to secure the representative rights of the people-not by a perfect and final measure, but by one containing the elements that would produce further and more theoretically perfect reforms, without the necessity of further fierec agitation. The counties generally sent pledged delegates. In Lancashire no tory dared to offer himself to the electors, and Mr. Stanley (now Lord Stanley) and Mr. IIeywood, of Manchester (now Sir Benjamin Heywood), were elected by acclamation.

The delegate parliament met on the 24th of June; on the 25th the Reform Bill was again introduced, on the 26th 
it was read a first time, and on the 4th of July the second reading was mored. A three days' debate followed, and on the division ministers had a majority of one hundred and thirty-six. Long and tedious delay took place in committee, the tories yielding only inch by inch, taking up fresh ground whenever driven from their position, and it was not until the 22nd of September that the bill passed the lower house; the country looking on quietly and confident as to the result, but prepared for instant action should any unforeseen obstruction arise. Many meetings, however, took place to prove to the House of Lords that there was no relaxation in the desire for fair representation.

On that 22nd of September a meeting was held in the Town Hall, Manchester, Mr. James Burt, the boroughreeve, in the chair. Mr. Richard Potter took the lead. "It had been said that the ardour for reform had abated, and this was one reason for holding the meeting, that it might be shown that the people were still animated with the same determined resolution which had been manifested throughout the long-protracted contest." Mr. M. Philips followed, and said, that misrepresentations of the state of public opinion might be expeeted from men whose selfish interests or whose want of prineiple prompted them to adrocate the continuanee of a system under which they had themselves fatted on the public plunder. A somewhat turbulent person, named Ashmore, a wearer-one of a class of men who, whether they were honest or not, were doing the work of the obstructives as earnestly as if they had been well paid for it-here rose and asserted that there had been a great alteration in public opinion about the bill, which, howerer, bad as it was, he would accept as a stepping-stone for more. A working man, named Thomas Jolnson, followed, who declared his convietion that the bill would be advantageous to the working classes, for which declaration he was hissed by Ashmore's small party. Mr. Thomas Heywood said that there was no evidence to show that the 
reformers of May and June were not reformers in September, and expressed his aversion to the corn-law, to repeal which would be the first duty of a reformed parliament. Mr. John Shuttleworth then addressed the meeting in a most effectire speech, in which he asserted that it was an imperative and most solemn duty, on the part of the minister, by advising an exereise of the king's prerogative, and by the ereation of the necessary number of peers, how large soever that number might be, to earry the measure safely through the House of Lords. Mr. Jeremiah Lloyd said that the delay in forwarding the bill had had one good effeet-it had shown that the demand for it was not from temporary excitement, but enduring conviction. Mr. R. HI. Greg expressed his convietion that the lords would pass the bill, for they must be aware that its rejection would be attended with uost disastrous consequences. Mr. James Whittle and Mr. Thomas Iarbottle supported the petition that had been proposed. Mr. J. C. Iyer, in a short and pithy speech, denied the right of the lords to interfere in the constitution of the other house, which ought to represent the people. MIr. G. Humphreys, in a first appearance before the public, ably asserted the justiee of the measure about to be submitted to the House of Lords. Mr. G. Hadfield characterized the bill as a confirmation of the revolution of 1688 , by the admission of the people to the power intended for them, but which they did not obtain, from the want, at that time, of a knowledge of the principles of representation. $\Lambda$ fter short speeches from Mr. G. H. Winder, Mr. E. Baxter, Mr. J. C. Walker, Mr. Thomas Potter, and myself, the meeting closed with three tremendous eheers for reform. A numcrous and equally enthusiastic meeting was held in Salford on the following week.

The second reading of the Reform Bill was moved in the House of Lorls on the 3rd of October. At a late hour Lord Wharneliffe moved an amendment, " that the bill be read a second time that day six months," and the debate 
was adjourned till next day, and from day to day, until, at four o'clock in the morning of the 7th, Earl Grey rose to reply. He concluded his address by saying: "If your lordships throw out the bill, it will rest with myself and my conscience how I shall shape my future conduct. But I will not abandon the helm of affairs so long as I can be useful to my king or my country." On the anxiously-expected division there appeared, contents 158 , non-contents 199 , being a majority of forty-one against the bill, twenty-one of the number being contributed by the bench of bishops. To soften the disappointment to the country-perhaps to avoid the consequenees to themselves-many of the opponents of the bill expressed their conriction that the time was come when some reform-" safe" and "gradual"ought to take place; and the Archbishop of Canterbury, on behalf of himself and the right reverend bench, said, " he was so thoroughly sensible that some reform was necessary, that to a temperale and safe reform he would offer no objections. He could not help indulging a hope that the discussions of that evening would lead to the introduction of such a measure as would ensure the union of men of all parties." There was no faith in such professions-no faith in reform from such sources. The conviction had been growing up, during the long-protracted discussions, that the measure, instead of going too far, had not gone far enough; and a new and fiereer agitation was commenced:

"The country pours amain,

The spirit of our ancestors is up,-

The spirit of the free! And with a roice

That breathes success, they all demand reform."

Farly on the morning of Monday the 10th, it was generally known throughout Manehester that actire measures were in operation for convening a public meeting, and in the course of the day a notice from the municipal authorities, in compliance with a requisition signed by upwards of four hundred merchants, and other inhabitants, was 
issued, inviting the inhabitants to assemble on Wednesday, in the Riding School, Lower Mosley-street, " to consider the propriety of presenting a dutiful and loyal address to his majesty, at this alarming crisis, for the purpose or assuring him of their derotion to his person, and of their unshaken determination to give to his majesty, and his present government, all the support in their power; and also of imploring his majesty to take such decisive constitutional proceedings as shall counteract the pernicious consequences which may result from the rejection of the Reform Bill by the House of Lords, secure the passing of that important measure into a law, and thus preserve the peace, and secure the future welfare of the country." At the hour appointed the street was filled with people who, the moment the door was opened, eompletely filled the place, to the number of four thousand, learing thousands more outside elamouring for adjournment. A rain attempt was made to proceed with business, but the cries for adjournment were overpowering. At length it was agreed that the meeting should be held in Camp Field, to which the whole assemblage proceeded, swelling as it went, until the number eongregated amounted to at least a hundred thousand, exeeeding, by forty thousand, the number met on St. Peter's Field on the 16th of August, 1819. The boroughreere having declined presiding at an open-air meeting, Mr. Thomas Potter, now beginning to take that active part in public business which he pursued during the remainder of his most useful life, was called to the chair and reeeived with tremendous cheers. He bricfly addressed the meeting, and called on the brother of the county member, to move the first resolution. Mr. Heywood spoke in a low tone of voice, with some hesitation, and was badly heard ; and it became obvious that there would be a demand for resolutions more in aceordance with the fierce temper of the disappointed multitude than those which were to be proposed. Mr. Shuttleworth's better voice and more 
assured tone made him well heard over the greater part of the meeting, and much of what he said was enthusiastically cheered, but his allusion to the nceessity of creating an additional number of peers was met by cries of "no more peers-we've had enough of them." A young man of the name of Richardson moved an amendment to the effect, that the king should be addressed to issue writs to populous places, to withhold them from decayed and rotten boroughs, and to create no new peers, but to take such other eonstitutional measures as should secure the passing of a bill on the principles of universal suffrage, annual parliaments, and rote by ballot. A seene of extraordinary exeitement followed. Mr. Shuttleworth and Mr. J. C. Dyer in rain attempted to show the propriety of adopting the resolutions proposed. I tried to show that a slight alteration of the amendment might secure unanimity, but was met with overpowering cries of "Don't humbug us." Mr. Humphreys begged the meeting to support the men who were fighting their battles in parliament, and the reply was: "We'll fight our battle ourselves." The utmost eonfusion prevailed, but on the amendment being put and declared to be carried, tremendous shouts rent the air, and thanks being unanimously roted to the ehairman, the enormous assemblage peaceably dispersed. My eomments on this meeting were:-

"The congregation of one hundred thousand of the inhabitants of Manchester was a proof of the interest which the publie feel on the fate of the Reform Bill, and ought, with similiar manifestations throughout the country, to convince the lords of the majority that the demand for reform is one which, instead of subsiding experiences fearful increase by opposition. The tories need not lay the flattering unction to their souls that the people will accept their as-little-as-ncedsbe seheme of reform, if they should succed in throwing out the present bill. If that bo ultimately thrown out, they may depend upon it that the people will be unanimous in demanding one with a broader extension of suffrage, and with complete protection to the roter. The meting, in consequence of the fury of a few foolish and mis- 
guided men, was not effectire as an expression of deliberate opinion, but it was most instructive as to the consequences of a branch of the legislature, whose hereditary sway is only tolerated, throwing itself as an obstacle in the way of the people's will."

The initated feclings of the people found more alarming expression in other parts of the country. On the 10th, 11th, and 12 th October much alarm was occasioned by the assemblage of tumultuous crowds; the Duke of Wellington was insulted on his way to the House of Lords; the Marquis of Londonderry was attacked and stones thrown at him, one of which struck him on the temple; and many of the most obnoxious amongst the nobility had their windows knocked in and broken. When the intelligence of the rejection of the bill reached Derby, a great crowd assembled, broke open the town jail and liberated the prisoners. The eounty jail was also attacked but successfully defended. $\mathbf{M r}$. Haden, a respectable inhabitant of the town, was struck with a stone, which caused his death. At Nottingham the disturbances were still more serious, and the rioting ended, after an attack upon Colwick Hall, the seat of J. Musters, Esq., whose lady died of the fright occasioned, by the destruction by fire of the beautiful eastle,-standing unroofed till the present day, a monument of blind fury,the property of the Duke of Newcastle, who had become unpopular, and had given a great inpulse to reform, by his insolent declaration relative to his dependant voters at Newark, that " he had a right to do what he liked with his own." On the 12th, larl Grey informed the deputies from various parishes of the metropolis that it would be absurd to think of again proposing I cord John Russell's bill, but they might be assured that the ministers would support no bill that would not secure to the people their constitutional rights. On the 26th parliament was prorogued by the king, who intimated the necessity of resuming, in the ensuing session, the subject of a constitutional reform. This did not, howerer, put an end to the disturbances, of which 
many, caring nothing about reform, joined for the sake of plunder. On the 29th Bristol became the scene of frightful and disgracing excesses on the publie entrance of Sir Charles Wetherall, recorder for the city, whose opposition to the Reform Bill, in the House of Commons, had been characterised by the bitterest and most unmeasured vituperation of all who promoted it. "The whole of Bristol," says Mr. Wade, "was on the verge of destruction; the mansion-house, custom-house, excise-office, and bishop's palace were plundered and set on fire; the toll-gates pulled down; the prisons burst open with sledge hammers, and their inmates, criminals and debtors, set at liberty amidst the exulting shouts of the populace. During the whole of the Sunday the mob were the unresisted masters of the city. Forty-two offices, dwelling-houses, and warehouses, were completely destroyed, exclusive of public buildings. The loss of property was estimated at half a million. The number of rioters killed, wounded, or otherwise injured, were 110. Of about fourteen or sixteen who lost their lives, three died from the shots or sword-cuts of the military ; the rest were mostly the victims of exeessive drinking, in the rifled cellars and warchouses, which produced either apoplexy on the spot, or disabled them from escaping from the flames that they had themselves kindled." I have spoken of the functions of the Manchester Political Union as being more to direct and restrain than to urge-urging not being required when the association was formed. The Bristol Union had not been so effeetive in preventing outrages, but when they had occurred, it was very influential in restoring peace. In my paper of the 5th of November, I said :-

Lamentable and disgraceful riots, attended with serious loss of life and immense destruction of property, have taken place at Bristol. It is impossible to read the frightful details without seeing the perilous condition of a country in which the mass of the people, having no roice in the choice of representatires whose enactments they are 
called upon to obey, nor in the choice of the magistrates who administer those laws, hare no respect for the authorities appointed for the conserration of the peace. The magistrates, knowing that they had no one feeling in conmon with the people, scem to have been completely paralyzed; and the mob, seeing their imbecility, seemed to hare proceeded from one act of violence to another, till, maddened by unexpected success, like the tiger which has tasted blood, they recklessly destroyed all before them, counting lifo and property as nothing. Is it possible that such horrible excesses could have been committed in any country where the people, having the enactment of their own laws and the formation of their own institutions, could say, "They are of our own making - we will enforce them; they are of our own creation-wo will support them ?" If, instead of a tory corporation, known for ages as adverse to popular rights, Bristol had been governed by magistrates appointed by the people, the riot would hare been quelled in an hour or two. The application of that corporation, after three days' fire and carnage, to the Political Union, is pregnant with instruction. It was an acknowledgement that the peace could be restored only by authorities appointed by the people. The correspondent of the Mforning Herald says : "Tho city may be said to be under the proteetion of the Pohtical Union, to whom the magistrates were constrained to appeal in the dreadful emergency, and the firmness and patriotisu displayed by the reformers merit every praise. Mr. Herepath, the vice-president of the Bristol Political Union, was rested by the nagistrates with an authority similar to that of the under-sherif. IIo was requested to asscmblo the members of the union-a courso which, it should be remembered, the rice-president had already determined on; and, armed with the power conferred on them by the magistrates, the reformers appliad themselves, in the most praiseworthy and successful manner, in the restoration of order." "It is impossible," sars the Bristol Merewry of Tuesday, "to speak of the laudable conduet as we could haro wished, displayed throughout the night by the members of the Poli. tical Union, acting in conjunction with the parochial authorities. The firmness and patriotism they have displayed on the present eunergenes entitle them not only to the esteem of their fellowcitizens, but to the gratitude of the whole country. A stronger contrast can searely be conceired than the good order of the last crening presented to the uproar and confusion of Sunday night. Under their protection we may now say that confidence is restored, though the city still bears the appearance of gloom, rery few shope 
being open and business still being in a manner suspended." The contrast of the good order of Tuesday morning with the uproar of Sunday erening is the contrast of an authority appointed by the people with one in whose appointment they hare no ehoice. Mr. Herepath was the legitimate magistrate, the corporation the usurpers. Under them, all was tumult and confusion; under him, was good order and confidence. Under their direction, the military only added to the irritation; under his direction, they were hailed as the restorers of peace. The eity abandoned to destruction, the reformers and the soldiery restored tranquillity.

Great efforts having been made to create disunion amongst the reformers, the council of the Manchester Political Union met on Wednesday, the 9th November, and agreed to a series of resolutions, two of which are subjoined :-

"That the members of this council, associated during the Wellington administration for the purpose of promoting parliamentary reform on the broadest basis, having since the introduction of the Reform Bill given it their warmest support, as a great improrement upon the present corrupt and imporerishing system, though it fell far short of their ideas of theoretic excellence, as every reform will, in which exelusion is not itself excluded, were grieved and alarmed at it rejection; and especially when it was reported, that, on being re-introduced, it would bo deprired of some of its best principles, in onder to render it more acceptable to an aristocracy adrerse to any extension of the suffrage.

"That while the members of this couneil feel it their duty to invito all reformers to unite with them in one call for the adoption of the ancient constitutional principle of suffrage, for the frequent exercise of the elective right, and for the protection to the roter from all undue influences; and though they think all these points are necesary to a thorough reform, and though they will continue to demand them as their right, they feel that it is a duty they owe to themselves to declare, that they will not oppose themselres to any such seheme of reform, whieh, though short of their own ideas of perfection, shall effect a real amendment upon the present corrupt system, and tend to lessen the evils introduced by a long train of misgorernment, while, by showing that their fears of the consequences of innoration are groundless, it may lead the way to the peaceable adoption of measures which shall restore to tho wholo people their long-lost rights, 
and sweep away every abuse in the state, the laws, and the ehurch. Their prineiple is to ADFANCE - to the extreme point as speedily as possible - but at all events, to ADYAXCE."

Such was the generous waiving of present demands, considered just and reasonable, which the reformers conceded to the whig administration, believing that when a beginning had been made, and made safely, they would acknowledge that principle of progression; and if they did not themselves urge on other reforms, would at least leave the shortening the duration of parliaments, the adoption of the ballot, and the extension of the suffrage, as open questions. It was an ungenerous return to declare the doctrine of finality - still more ungenerous to act upon it when the declaration of finality was denied. 


\section{CHAPTER XXVI.}

THE REFORM BILL PASED.

THE new parliament assembled on the 6th December, 1831. There was faith that reform would be carried, beeause there was the determination that it should be carried. The obstructires might appear in unexpeeted strength, the administration might falter in its course, and the king might yield to unseen and mischierous influences; but the people were determined to have reform, peaceably if they could, but to have it. Every thinking person saw that there was to be either reform or revolution, and felt eonvinced that the one would be yielded rather than that the risk of the other should be incurred. "There was something unusually solemn," says Miss Martineau, "in that meeting of parliament on the 6th December." It was ecrtainly a season of much solemnity, for great issues were to be tried, but it was one in which hope greatly preponderated over fear. The result was not watehed with the anxiety with which we wait the rerdict of a jury, shut up until they agree. The country had already pronouneed the rerdict, and parliament was assembled only to pút it upon record.

Lord John Russell brought forward his new bill, in the House of Commons, on the 12th December. On Friday, the $16 \mathrm{th}$, the sccond reading was moved, and the debate did not come to a conclusion until Sunday morning, the 18th, when the majority was 162 in a house of 486 . An adjournment took place till after the Christmas holidays, and the contest was resumed on the 17th January, 1832. The house went into committee on the 20th, and every possible device to obstruct and to delay having been resorted 
to, it was not until the 19th of March that the third reading was moved. On the 22nd the motion was carried, 355 voting for and 239 against it.

$\Lambda$ more donbtful contest was to take place in the House of Lords. They had defeated the former bill, and it was known that, although many converts had been made, there was still a majority of obstructives there; yet few would believe that they would risk the existence of their own order by the positive rejection of the bill, and the only fear was as to its possible mutilation. The talk amongst the pcople was, that if the lords rould not permit the commons to be reformed, their lordships' own house should be reformed-or abolished. On the 26th March the bill was introdued there and read a first time. On the 5th April, Earl Grey moved the second reading, and a four days' debate took place, ending with a division which gave 184 rotes for and 175 against the bill. It became obvious that the measure would either be mutilated or lost in committee unless peers were ereated for the emergency. Numerous large meetings were held, intended to strengthen the hands of ministers if they stood firm to the integrity of the bill; there was the expression of a determined resolution, without any great amount of excitement; there was still the belief that means would be found to force the measure through the obstructive house. The Easter holidays being over, the House of Lorls met on Monday, the 7th May, and resolved itself into a committec upon the bill. Lord Lyndhurst moved that the disfranchising should be postponed until after the consideration of the enfranchising clauses. The motion was earried by a majority of 35 . It was now seen that the intention was, regardless of consequences, either to mutilate or destroy the bill. On Wednesday, ministers finding that the king was not disposed to use the only means left to influence the lords, resigned office, and the Duke of Wellington was sent for. The people rose, almost as one man, with the manifestation of 
one determined will. A crisis was come. Reform had been refused, and the other alternative was foreed on every one's consideration. It was understood that the military had received their instructions. Alexander Somerville, in his "Autobiography of a Working Man," says that "the Scots Greys at Birmingham had orders to rough-sharpen their swords, that they might inflict a ragged wound;" but there were rumours also that the soldiers would not act against the people. If the king did not exercise his constitutional prerogative to ensure the passing of a measure so imperatively demanded a revolution must ensue. Men pondered whether it would be a three days' contest, as in France, or a protraeted and bloody civil war.

The intelligence that ministers had resigned reached Manchester soon after seren o'clock in the morning of Thursday. It was eirculated with inconceivable rapidity, and the sensation it ereated was beyond description. Business was at once suspended. Purehasers for the home market, fearing insurrection, would buy no more. Foreigners, dreading the effect upon the foreign policy of this country that would be the result of a tory administration being restored, with all its leanings in favour of continental despotism, countermanded their orders. The shopkeepers left their places of business, and ran about asking, "what is to be done now :" The working classes, in every district of the town, gathered into little knots, and, with curses both loud and deep, expressed their hatred of the faetion whose intrigues had prevailed over the roice of twenty-four nillions of people. There had been a committee appointed at the September reform meeting in Manchester, and it had resolved to sit every day at the Town Hall till the bill was safely passed through the House of Lords. Here, then, merchants, manufaeturers, and others simultaneously assembled, until, with that committee, they formed a highly respectable and numerous public meeting. Mr. John Shuttleworth was called to the 
chair, and the following petition, prepared by Mr. Absalom Watkin, was read amidst loud and enthusiastic cheers :-

"to THE hoxotrabre tHe coMross, \&c.,

"The Petition of the undersigned Inhabitants, \&c.,

"Sheweth,-That your petitioners hare heard, with feelings that it is impossible to deseribe, that the Reforn Bill has again been virtually lost in the House of Lords, and that Earl Crey and his administration have, in consequenee, been compelled to withdraw from his majesty's councils; - that your petitioners, considering that the plan of reform which has been defeated was a measure which merely restored to the people a right to whieh they were always entitled by the constitution, and of which they have been too long defrauded by a faction; considering also that the bill had been twice passed by your honourable house, and was earnestly desired by the people; and, moreorer, that it is a measure which legally and honestly can affect the people and their representatires only; - are at a loss to find words to express their indignation at being denied their birthright, by the manceurres of a small number of interested indiriduals. That your petitioners being thus situated, hare recourse to your honourable house as the constituted organ of their wishes, and their established defence against injustiee and arbitrary rule, and do pray your honourable house that you will assert your own colleetire dignity, and the indefeasible rights of your fellow subjects by determined adherence to the bill, and by refusing to rote any supplies until a measure essential to the happiness of the people and the safety of the throne shall be carricd into a law."

'The petition was agreed to, without a dissenting voice, and it was resolved that it should be carried to London that same evening, by a deputation consisting of $\mathrm{Mr}$. Richard Potter, Mr. Joln Ficlden, and Mr. Shuttleworth. The writing of the petition was not concluded till one $0^{\circ}$ clock, and it was twe before placards could be got out, stating where it would lie for signature, and nearly three before all the sheets were distributed to the appointed places; but at six o clock the signatures amounted to TwExTY-Four Tiroussxi. The deputation then started in a chaise and four for London; thousands of persons enthusiastically cheering them as they drove off. As they 
did not change horses at Stockport, the inhabitants were not aware of the object of their journey, but at Macelesfield a number of people collected, and with loud cheers testified their gratification at the promptitude which had been displayed at Manchester. At Leek, in consequence of some delay in changing horses, the business of the deputation got known, and in a few minutes almost the whole population were in the streets. A short account of the meeting was distributed amongst them, and also the petition to the commons. The crowd was so dense, that the carriage could not proceed for some time; the checring of the people was loud and continued, and numbers pressed forward to shake hands with the gentlemen of the deputation. Although it was midnight when they passed through Derby, several persons soon collected, and expressed their satisfaction that Manchester had set so good an example. Loughbrough and Leicester were passed through in the dead of the night; but Mr. Potter put some of the resolutions in the post, directed for his friends there. The deputation reached Northampton about five in the morning; the object of their journey soon spread, and the inhabitants, on hearing the shouts of the people, repaired to their windows, eagerly inquiring what was the matter, and on being told, wared their hands and wished success to the mission. In the small towns from Northampton to London, the gentlemen were'. everywhere welcomed with the utmost enthusiasm. They reached Palace Yard a little after eleven, having performed the journey in seventeex HodRs, a wonderful feat in those days, though at several of the towns they passed through in the night they had to wait generally a quarter of an hour, and lost, at least, an hour and a half in this way. At every town and village they distributed a short account of the meeting, and the petition; and as they approached London, copies of the petition were distributed to the passengers of the numerous coaches they met, so that in the course of 
that day intelligence of the Manchester meeting would be spread throughout the greater part of the kingdom. Inmediately on the deputation reaching London, they repaired to Westminster Hall and the committee rooms, and they soon found John Wood, Esq., the patriotic member for Preston, who instantly put his own name and $\mathrm{Mr}$. Heywood's on the speaker's list, to obtain precedence in the presentation of the petition, and it was owing to this prompt proceeding that the petition was presented that rery night. Mr. Wood, amidst the eheers of the whole house, made a most energetic and well-timed speech. After securing the presentation of the petition, the deputation called on Mr. Heywood, Joseph Hume, Daniel O'Connell, Col. Evans, Mr. Tomes, and sereral other friends of reform, requesting them to support the prayer of the petition, and were received most cordially.

The Manchester petition was the very first which was presented praying the House of Commons to stop the supplies until reform and a redress of grievances were obtained. There being no house on Saturday, its presentation on Friday was most opportune, for the example was eagerly followed by all parts of the kingdom. On Saturday and Sunday the petition was the general subject of conversation in London. On Saturday the deputation were engaged in ealling on sereral members of both houses, to gire them personal assurances that not only was there no abatement in the desire for reform, but that the probability of the formation of a ministry adverse to it had roused a spirit which would render it impossible for any such administration to conduct the aff:irs of government.

The extemporaneous meeting on the Thursday had been held at an hour of the day when the working classes had not the opportunity of attending. It was desirable that they should have their share in the demonstration, not to increase the excitement, but that it might be regulated and kept within constitutional bounds. There was no need 
to urge onwards; more need was there to restrain, or at least to keep in the right and peaceful direction a feeling smarting under the universal conviction of a great wrong and insult haring been offered to the nation. - It was felt that a thoroughly public expression of opinion was the legitimate and safe course. A meeting was appointed to be held on the following Monday, on St. Peter's Field, the scene of former meetings when to ask for reform was a crime- to be the scene thereafter, in an enormous hall erected for the express purpose, of a long series of crowded meetings to agitate for that measure of free-trade which ought to have been the very first result of the Reform Bill. The area was now limited to 8,000 square yards, on which were congregated 40,000 persons of all ranks and conditions-not one-third women and children as on the 16th August, 1819, but all men, determined men. Mr. Charles James Stanley Walker, son of Thomas Walkcr, whose trial, in 1794, has been given in the commeneement of this volume,- " honoured son of an honoured sire," as one of . the speakers designated him,-was called to the chair. The venerable Robert Philips, of Park, still holding the principles he had supported in 1792, mored the first resolution, "That this meeting has heard of the rirtual loss of the Reform Bill in the House of Lords, and the consequent resignation of Earl Grey and his colleagues, with such sentiments as it becomes Englishmen to entertain when their best interests are basely sacrificed to the selfish views of a faction." Mr. Philips's son-in-law, Mr. Robert Hyde Greg, seconded the motion. Alluding to the former meeting, which he had attended, he said :-

"Ho had flttered himself that the next time he lad the pleasure of addressing his fellow-countrymen, it would hare been for the purpose of congratulating them and the country on the rictorious eon. summation of their struggle in lonving shaken off the burthen which had so long pressed them down-that ineubus and nightmare, the boroughmongering faction. (Great applause.) But the prize, it scemed, was too great and raluable to bo obtained on sueh easy terms. 
After eighteen months of anxiety - after the heary expense which the country has incurred by the general election-after the sufferings of the people, from the sickness of the heart from hope deferred - it seemed that the nation was again called upon to fight the battle of reform. (Applause.) The boroughmongers were determined, it semed, to make a desperate struggle to retain their ill-gotten wealth and inisused influence, but their groans and hearings were those of dying men. (Cheers.) But as they had thrown down the gauntlet, let it be taken up by the nation (long eontinued cheers) - and God defend the right." (Renewed and enthusiastic applause.)

Ir. Joseph Johnsou, who had endured a year's imprisonment for having appeared on the hustings on that very spot thirteen years before, mored the next resolution, "That this meeting, satisficd that the ministerial plan of reform was no more than a partial restoration to the people of a constitutional right of which they have been too long unjustly deprived, and well knowing that no part of the bill could, directly or indireetly, interfere with any legal or honest possession or privilege of that body by which it has been defeated, is unable to find language sufficiently strong to express the indignation with which it has witnessed this second refusal of an acknowledged right." At the conclusion of his speech, Mr. Johnson said, that "if the people were satisfied to try the bill; if they were satisfied to give up a portion of their rights for the purpose of trying how the measure would work"- - here he was interrupted by loud eries of, "We are not satisfied ; we want the whole.") The speaker resumed: "I am for the whole; but let us get this bill if we can; and if it loes not work well, let us go for the whole of our rights." Mr. Thomas Potter, now and henceforward to take a generous and most influential part in public affairs, in seconding the motion, said it was impossible for him to find words sufficiently strong to express his indignation of the eonduet of the House of Lords in rejeeting the Reform Bill. Mr. Johnson's speceh, and the resolution he had read, had been very indistinctly heard, and there were strong symptoms that the resolution had 
been misunderstood, as committing the meeting to the bill as a perfeet measure, instead of being accepted only as an instalment. I saw the danger of a division, which would have been to strengthen the resisting faction, and begged leave to read the resolution again, which I did loudly, slowly, and emphatically, so as to be heard by everybody in the meeting, to show that it referred to only a partial restoration of the people's rights. In the course of my address, designed to show that nothing but eonstitutional means should be used, and that physical foree should not be resorted to until the very last extremity, I said :-

"The object of the present meeting was to obtain support to the potriots who were now fighting their battle in the House of Commons; and he hoped reformers, one and all, would put aside all minor differences, and unanimoukly agree in one object, namely, the stopping of the supplies. (Cheers.) If they did not obtain their wish by that course, there were other means, namely, that haring raised their hands here in supnort of the resolutions to obtain their rights, then - after all constitulional means had failed - then if would be time to hold up their hands with something in thems. (Tremendous cheers, which lasted some minutes.) He had always counselled peaceable and quiet measures, and he knew that he hud sometimes rendered himself unpopular by it, when indignation hurried men into rash thoughts; but though he had always adrised quiet measures, he knew what measures to propose after all these had failed. (Checrs.) * He concluded by begging the reformers of Manehester to sink all little differences of opinion, and to seek the attainment of their purpose by peaceable and constitutional means. It might be that there were some present that day who did not go so far as himself, and others did; but the meeting should bear in mind, that in the event of an attempt to form a Polignae adminiitration, the gentlemen who had framed the resolutions, moderate as they might seem to be, might in a fe rtays be suffering within the walls of a prison. These were times to try men, but he hoped that the meeting would follow noderate counsels, although nt tho same time they ought to be ready and deternined to struggle for their rights." (Loud elieers.)

The dissatisfaction expressed by a portion of the meeting was now removed, and Mr. Flijah Dixon, one of the impri- 
soned of 1817 , and a working man named Thomas Johnson haring expressed their approval of the resolution, it was put and carried unanimously, followed by three hearty cheers. Mr. William Harrey moved the next resolution: "That this meeting concur entirely with the petition that has already been sent from Manchester to the House of Commons on this subject, and does hereby solemnly call upon that house to adhere, with steadfast and unyielding determination, to the bill; and, above all, to vote no supplies whatever, until the bill, or a measure in every particular, at least, as favourable to the rights of the people, shall have passed into a law." Truc to his temperance principles, Mr. Harrey said they could not legally pass a resolution that they would pay no more taxes, but they could resolve amongst themselres not to consume spirits, malt, tobacco, and other unnecessary articles that contributed heavily to the revenue. Mr. James Whittle seconded the resolution,

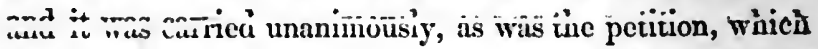
was direeted to be signed by the chairman. $\Lambda$ cordial rote of thanks to the chairman having been passed, he said he had always been a reformer,-he was born a reformer,and, if it pleased God, he would die a reformer. Ho was confident there was such a moral force in the country as would render an appeal to physical force unnecessary.

Another meeting was held in the adjoining town of Salford, which, under the bill then in jeopardy, was to have a separate member. Mr. William Hill, the boroughreere, presided. The speakers were Mr. Hill, Mr. John Smith, Mr. Joseplı Brotherton (to whose exertions was mainly owing the inclusion of the town in the list of boroughs to be enfranchised), Mr. Folland Hoole, Mr. Mark Philips, following the example of his venernble father, Mr. Heron, Mr. Thomas Hopkins, and Mr. Ormerod. One was also held in Chorlton-upon-Medlock, then called Chorlton Row, which was becoming a very populous township. Mr. Joseph Wood, the senior constable, was in the chair, and 
the meeting was addressed by Mr. James Wood, Mr. Henry, Mr. Samuel Fleteher, Mr. Burdekin, Mr. Thomas Wheeler, Mr. Westhead, Mr. Kershaw, and myself. Similar demonstrations were made in the many large manufacturing towns which surround Manchester.

On Monday, the 7th of May, there was a congregation of the political unions at Birmingham, composing the largest meeting erer held in Great Britain. The Bromsgrove union, which arrived late on the field, was greeted with the Union Hymn, ending :-

"God is our guide! No swords we draw,

We kindle not war's battle fires;

By union, justice, reason, law,

We claim the birthright of our sires.

We raise the watchword Liberty!

We will, we will, we will be free."

"Before the echoes of the hymn had well died away," says Miss Martineau, "before the tears were well dried which the plighting of faith had brought upon many cheeks, the lords in London had clecided, by a majority of thirty-five, against the disfranchising clauses." Birmingham, after that pause of a day, again took the lead, and the unions were ererywhere at work. The Common Couneil of London petitioned parliament to refuse the supplies, and appointed a committee to sit daily till the bill should be seeured. Throughout the kingdom men speculated on the point whether the military would join with or take part against the people; but none swerved from the determination, let the military act as they would, that the bill should pass unmutilated-in its full integrity. There was a TEx DArs' agitation as fearful to the obstruetires in our kingdom as the TIREE DAYs of France were to Charles $\mathbf{X}$ and his Polignae administration.

On Tueslay, the 15th of May, Lord Grey in the Ifouse of Lords, and Lord Althorp in the House of Commons, announced that eomnunications had been renewed between 
the sovereign and themselves which rendered it expedient to adjourn till Thursday. It was known that ministers would not have resumed office unless they were assured that they should have the sorereign's aid in passing the bill. "'The words were seareely uttered," says Miss Martineau, in her interesting history of the period, "before there was a rush from the houses to spread the tidings. There was no eleetrie telegraph then, but the news flew as if by electrie ageney. By breakfast-time uext morning placards were up in the streets of Birmingham, and presently the people thronged to Newhall Hill, after bringing Mr. Attwood into the town. As by an impulse of the moment, a minister present asked to offer thanksgiving, and that prayer-that derout expression of gratitude for their bloodless victory, and their privileges as exulting freemen, was felt by the throng to be a fitting sequel to their last week"s solemn vow." On the 7th of June the Reform Bill beeame law.

In the interval, Manehester, about to be enfranchised, was already looking out for representatives, and it beeame obrious that some who had eome into the field only when vietory was of eertain achievement, would seek honourable reward for their late excrtions. One defect of the Reform Bill was now very obvious. In my paper of the 2nd of June I said :-

"Regarding the Reform Bill as now beyond danger, and expecting that in another week we shall be enabled to announce that it has become the law of the land, our minds are naturally directed to the consideration of what persons will be fit and proper representatives of the new constitueney; and the first thing that strikes us is, the neessity of the bill being accompanied by another, of some halfdozen lines, to REPEAL THE SEPTExXIAL ACT, or that a positive pledge should be required from each candidate that he will relinquish his seat at the end of a term of not longer than three years. Alnost every onc who is to have a vote las felt the difficulty of making a choice of men upon whoin a thorongh dependence can be placed that they will ably and earnestly labour for these pusctical RE- 
Fonxs of which the bill is only the precursor; and the diffieulty assumes a formidable shape, when it is considered that an error in the selection is irremediable for seven years! We are of opinion that circumstances will produce right opinions, and the vigour of mind necessary to enforce them, but we fear that they will not produce this effect in time for the eleetions. It is impossible to look round us and see men who have no other claims to a seat than the merit of having, at the elerenth hour, and when the passing of the reform bill was obriously inevitable, given it their support, and to know that such to be suspected reformation is by many regarded as a reason for selection, without feelings of almost dismay at the possibility of sueh an exercise of the suffrige, as shall send, for sEvEN IEARs, representatives to the house eontent to follow in the course of their predecessors, the borough nominees, without one single effective struggle for these measures which are absolutely necessary for the comfort of the people, and the national safety. The term of soren years is too long to inrest any man, especially any untried man, with the representation of opinions.

Well may the Manchester conserratives desire to return, as a representative, one (Mr. Stanley, now Lord Stanley) who, under the cloak of whiggism, would be found exerting rather formidable talents in resisting those practical reforms, which, by extending the commercial relations of the country, and lessening to the lowest practicable extent its burthens, shall raise it from that gulf of wretchedness, into which the borough owners and the aristocracy have sunk it. No, no! We must hare no such members for Manehester. FreE-Trade, curap COVRRNMENT, PROQREssite REFonM, are what the electors want, and though they hail the bill, as'an immense improvenent in the representative systen, they will gire their suffrages to those only who will heartily, and with ability, promote those means of ameliorating the condition of the people."

Manchester was, at last, enfranchised. We have traced its history through a long series of ycars, during which trnnquillity and comfort were only exceptions to the rule of misery, at periods intolerable. It has been shown how, by long and stern teachings in the bitter school of adversity, its inhabitants were slowly convineed that they needed better government to preserve their trade, and eren their existence. It has been shown how the despised minority, patient and persevering, becume the overwhelming majority. 
It has been shown how one reform, to be the instrument in obtaining other necessary reforms, was, at length, triumphantly obtained. To show how that instrument was used, and what part Manchester took in other struggles for measures which ought to hare been the very first fruits of the reform act, would be fit oceupation for the pen of a competent writer, when, after a little more lapse of time, the further period of excitation can be looked back upon with a calm impartiality becoming the historian. 


\title{
SUPPLEMENTARY CHAPTER.
}

\author{
SOCIETY TO PUT DOWN LEVELLERS.
}

ON the 11 th of December, 1792, a church and king nob made a furious attack on the printing office of Messrs. Faulkner and Bireh; and on the house of Mr. Thomas Walker, as described in my first ehapter. The suecess of those resorts to physical foree encouraged the then leading men of Manehester to make a more systematic organization against the reformers. On the following day a meeting was held, and the following resolutions passed:-

“Bull's Head, Manchester, December 12, 1792.

"An association for preserring constitutional order and liberty, as well as property, against the various efforts of levellers and republi: cans, entered into at Manchester, the 12th dny of December, 1792, upon the principles contained in the following declaration.

"We whose names are hereunto subscribed, scriously considering the affairs of this juncture, and the various efforts of restless, disaffected persons, tending to subrert the happy rights and liberties equally enjoyed by all descriptions of persons under the auspicious protection of a long experiense and unirersally renerated constitution and gorernment, composed of king, lords, and commons, - do determine to form ourselres into an association under the abore title, and solemnly engage to afford the most vigorous excrtion and support to the executire power of this country in counteracting all attempts of sedition and treason. And for these purposes we deelare and resolro as follow :-

"That we will, by every legal measure, endearour to diseorer and bring to justice the authors, publishers, and distributors of all seditious and treasonable writings, and especinlly all persons who shall be engaged in any societies or combinations for the dispersion and promotion of sueh doctrines.

"That we will, by the distribution of plain and undisguised constitutional prineiples, endearour to undeceive suelı persons as may be misled by the sinister and inflammatory insinuations of designing men." 
"A committee was fonned, lonsisting of James Aekers, John Leaf, and Joseph Hardunn, the boroughreve and constables of Manchester, the magistrates for the hundred of Salford,

\begin{tabular}{|c|c|c|}
\hline $\begin{array}{l}\text { Nuthmi Crompton, } \\
\text { IIenry Furrington, } \\
\text { William Major, } \\
\text { Samuel Clowes, jum., } \\
\text { Janes Borron, } \\
\text { Asliton Ethelston, } \\
\text { Nathaniel Kirkman, } \\
\text { James Broom, } \\
\text { Joseph Bower, }\end{array}$ & $\begin{array}{l}\text { Irolland Aekers, } \\
\text { James Radford, } \\
\text { IIenry Barton, } \\
\text { Willian IInll, } \\
\text { Rer. Joln Gatlif, } \\
\text { Jonathan Beerer, } \\
\text { Nathaniel Milne, } \\
\text { William Barrow, } \\
\text { John Ridings, }\end{array}$ & $\begin{array}{l}\text { Robert Pcel, } \\
\text { John Simpson, } \\
\text { Lawrence Peel, } \\
\text { Josepll Pickford, } \\
\text { Robert Markland, } \\
\text { William Douglas, } \\
\text { James Bateman, } \\
\text { William Fos, } \\
\text { James Barton, }\end{array}$ \\
\hline
\end{tabular}

"Sixty-seren names are attached to the declaration."

The committee appointed lost no time in going to work, for on the same day they made the following orders, offering a strong temptation to spics who could give them information, and thanking the publicans for their declaration as printed in the eighth page of my first chapter.

"Committce Room, Bull's Head, Doc. 12, 1792.

"Orders of the committee of association for preserring constitutional order, liberty, and property, against the various efforts of levellers and republicans.

"At a meeting of the committce this dny, James Ackers, Fisq., in the cliair :-

"Odered,-That John Simpson, Fsq., be appointed treasurer to this society; and that Henry Farrington, William Hall, James Barton, Thomas Stott, and William IIodson, be appointed to audit the treasurer's account.

"That the Rer. John Gintliff be nppointed sceretary to this society, with thanks for his aceepting the ofliee.

"Ordered,-That ten thousand copies of the declaration and resolutions of the meeting on Tuesday shall be immedintely printed.

"That a reward of ten guinens shall be given by this conmittee to any person or pereons who will come forward, and give such evidence as will discover und bring to justice any person or persons guilty of writing, printing, publishing, or clispersing seditious and treasonable writings, books, or papers, or be guilty of any other species of treason ore vedition, and particularly those who may have attempted, or shall 
hereafter attempt, to seduce any of the suldiers from their allegianee to the king, by circulating any treasonable or seditious doetrines.

"Ordered,-That the thanks of the committee be given to the innkeepers for their laudable conduct in forbidding all seditious moetings to be held at their houses.

"Ordered,-That a person be stationed at the door of the com. mittee room, to interrogate erery gentleman whether he is a nember of this eommittee, and to assist the secretary when required; and that he be appointed and paid at the secretary's diseretion.

"Ordered,-That in order to put in force the resolution for the publication of true constitutional prineiples, a committec of the nine following gentlemen be appointed, viz. :-Samuel Clowes, Esq., Rev. Mr. Sandford, Mr. R. Foxley, Rev. T. Radeliffe, Mr. Charles Lawson, Rev. T. Seddon, Rer. F. Hall, Rev. T. Grifliths, and Mr. F. Williams."

The society seems to have been afraid of working in brond daylight, as its minutes, also not intended to be seen in the daylight of forty-eight years afterwards, clearly show:-

"Committee Room, December 14, 1792.

"Samuel Clowes, jun., Esq., in the ehair ;-

"Ordered,-That overy member sign the declaration of secrecy before admittance into the committee room.

"Ordered,-That the thanks of this meeting be giren in a handbill to Mr. Martin Marshall and his son, for their endearour to quell all tumult on Tuesday erening, and to all other gentlemen who were active in the same eause.

"Ordered,-That no attorney of this eommittee be coneerned, either directly or indirectly, in the defenee of, or advice eoneerning, any prosecution that may hercafter be commeneed against any person or persons in cases of treason or sedition."

The latter resolution covered a wider object than appears on its face. No attorney in the body was to defend the prosecuted; any attorney out of the body, guilty of defending a "leveller" was to be persecuted. 'The next object was to fraternise with and to direct less influential associations.

"Committee Room, Deember 17, 1792.

"Samuel Clowes, jun., Esq., in the chair;-

"Ordered,-That the thanks of the committee be giren to the members of the IIiberninn Societr, \&e. \&e. 
"That Mr. Robert Gorton, Mr. Robert Hindley, and Mr. Thomas Norris were proposed as members of the committee.

"Ordered,-That the thanks of this committeo be given to the innkecpers of Stockport, Bolton, and all neighbouring towns, for their endearours to prevent seditious meetings and disturbances."

"Committee Room, December 18, 1792.

"Mr. Joseph Tipping in the ehair; -

"Messrs. Gorton, Hindley, and Norris clceted."

"General Mecting, December 19, 1792.

"Samuel Clorres, Esq., in the chair.

"Ordered,-That the thanks of this and the Salford committeo shall be giren to the Salford association for their offers of co-operation with the resolutions of this socicty.

"Ordered,-That 2,700 copies of the paper, viz., 'Minutes of a eonversation at the Royal Oak,' distributed on the 11th of December, be paid for at the expense of this association.

"Ordered, - That something be prepared by the committee of papers, in order to counteract any bad effects which may arise from Mr. Samuel Greg's misrepresentation."

"Committee Rooms, Bull's Ilead, Dec. 20, 1792.

"Dr. White in the chair;-

"Ordered,-That copies of the seyeral papers published by this association be sent from time to time to the Rev. Mr. Farcett, of Oldham, to be distributed there at his direction; and that the secretary write to him aceordingly.

"Ordered,-That the thanks of the committee be giren to Robert Peel, Esq., MI.P., for the rery handsome manner in which he defended the Mranchester associntion against the unfounded attack of Mr. Greg, in the House of Commons, on Monday, the 17th of this month."

"Committee Room, December 21, 1792.

"Mr. Janes Cooke in the chair;-

"In consequence of a letter sent to the chairman by society under the title of 'Churcl and King Club,' held at the Wearers' Arms, Cockpit-hill, it was ordered that two members of this committee, riz., Mr. Phethean and Mr. T. Norris, shall wait upon that society with the association book, for their signatures, on Monday next." 
And now commenced the proceedings which ruined Faulkner and Birch, and put down their paper:-

"Committee Room, Dec. 24, 1792.

"Mr. M. Boardman in the ehair ;-

" Read a letter from Robert Peel, Esq., to Dr. White.

"Ordered,-That a paper called the Manchester Herald, of Dec. 22,1792 , be recommended to the consideration of the committee on papers.

"Ordered,-That Messrs. Mrilne and Serjeant be requested to send Faltner's last paper to Messrs. Chamberlain and White, Solicitors to the Treasury, and to desire they will give such opinion as they may think proper as to the legality of it."

"Committce Room, January 7, 1793.

"Rer. R. Sandford in the chair;-

"Ordered,-That 2000 copies of the publieation called 'Equality' be printed by Mr. Wheeler, at the expense of the committee."

"Committee Room, Janunry 14, 1793.

"Rev. J. Griffith in the chair ;-

"Ordered,-That two publieations sent by Butterworth Bayley, Esq., be laid before the committee of papers."

Thirty-four persons are thus marked out for persecution, and, if possible, for prosecution. The list includes the names of some of the most respeetable, both as regards station and character, of the then inhabitants of Manchester :-

"Committoe Room, January 17, 1793.

"Samnel Clowes, Esq., in the chair ;-

"Ordered.-That the magistrates acting for the Manehester district be requested to summon the following persons to appear before them as soon as possible, and to take the oath of allegianee to his majesty King George the Third :-

Thomas Walker, merchant.

Thomas Cooper, whitster.

Richard Roberts, merchant.

Thomas Bateman, cotton dealer.

Thomas Kershaw, calico printer.
W. Hibbert, merchant. Samucl Greg, merchant. T. Robinson, merchant. Rev. M. Hawkes, Princess-st. T. Nightingalc, Fountain-street. 
Mr. Seddon, attomey-at-law.

Riehned Walker, merchant.

G. Wakefield, merchant.

s. IIardman, merchant.

R. Norris, merchant.

R. Collier, surgeon.

s. O. Birch, Manchester.

George Philips, merchant.

Samuel Jackson, cotton dealer.

William Rigby, jun., merchant.

Mr. Paul, paper stainer.

Ottiwell Wood, merchant.
John Grimshaw, merchant.

M. Grimsted, schoolmaster.

G. Duckworth, attorncy-at-law.

- Ogden, surgeon.

J. Ford, tinman.

G. Sulvin, merchant.

- Rees, calico printer.

Jolnn Ainsworth, merchant.

- Pricstley, merchant.

Jolin Fort, calico printer.

- Mounsey, merehant.

Allan Jackson, cotton dealer.

The following, from a society every member of which was bound to keep its proceedings secret, is a very rich specimen of impudenee :-

"January 24th, 1793.

"Samuel Clowes, Esq., in the chair ;-

"Ordered,-That the following advertisement be published in the Manchester papers :-

"Wherens some persons have assembled at different times under the appellation of a 'Constitutional Society', and have published rarious resolutions, signed by Thomas Walker and others, as presidents, and Samuel Jackson, as secretary to the said socicty.

"We, the committee of an association established at a public meeting upon real eonstitutional prineiples, do eall upon the members of thut society to publish their names and places of abode, for we think it highly necessaay that those should be known who have taken so inuch pains to enlighten the minds of the people, by recommencling to their particular attention a book published by Thomas Paine, entitled 'The Rights of Man,' a publication of most seditious tendency, and which has been proved by a British jury to be a libel upon government. Who have also entered into a correspondence with the Jaeobin Club of Paris, the avowed enemice of religion and of kings, which acts directly contradict their pompous declaration and reputed nssertions, that a reform in the lower house of parlinment is their only object, and that they have assumed the title of 'Constitutional Society', to impose upon the ignorant and unwary, and to overt urn that very eonstit ution they pretend to support. The conmittee likewise beg lenve to put the following queries to $\mathbf{M r}$. Thomas Wnlker :- 
"Whether his appearance, as a principal in these transactions, has not been the means of exasperating the people against him; and whether the attack upon his house may not be attributed to that cause?'

" By what acts have any of the respectable inhabitants of this town deserved the opprobious epithets of ' the Enemies of Freedom and the Friends of Despotism?"

"As to the still more opprobrious term of an 'unprineipled faction,' whieh Mr. Walker has likewise thought proper to apply to some of his townsmen in his letter to his friends and fellow-citizens at Sheffield, when the Constitutional Society hare published their names, the public will have an opportunity of judging who best deserre that appellation.

"Ordered,-That the committee of papers meet on Tuesday at eleren o'clock, and that Mr. Starkie's sermon be taken into consideration."

A law was had to put down what were called "corresponding socictics," and thus to put down the reform principles which those associations adrocated. It will be seen by the following minutes that this loyal and secret Manchester society, established to put down reform principles, was not to be bound by legal enactments :-

"January 26tl, 1793.

"Dr. White in the chair;-

"Ordered,-Read the depositions of Martin Marshall, Mr. Tate, jun., and James Hallows, with Mr. Topping's opinion thereupon."

\section{"Rer. R. Sandford in the chair ; -}

"January 31st, 1793.

"Ordered,-That Mr. Dauntsey Hulne be requested to present the Moravians with the thanks of this society.

" Read, a letter signed 'Amicus.'

"Ordered,-That Mr. Webster be requested to make all the inquiries possible respecting the information given by 'Amicus.'

"N. Gould unanimously elected a member of the committee. "Joln Griffith, Secretary."

"February 7th, 1793.

"Sumuel Clowes, Esq., in the chair ;-

" Rer. Mr. Derby unanimously elected.

"Ordered,-That the thanks of this meeting be transmitted to the boroughreere and constables of this town for their rery proper and 
spirited conduct respecting Mr. T. Walker's answer to the letters of condolence from the Constitutional Society at Sheffield, and that the same be published in the three Manchester papers."

"October 22nd, 1794.

"James Entwistle in the chair ; -

"Resolved,-That Mr. Harrop be paid at the expense of this com. mittee for nine copies of the 'Report of the Committee of Secrecy of both Houses of Parliament.'

"Read, a letter from MIr. Paynter respecting some expenses incurred in obtaining evidence against several seditious persons."

"April 7th, 1795.

"At a meeting of the Association for Protecting Liberty and Property against Republicans and Levellers,

"John Kearsley, Esq., in the"chair;-

"Resolved,-That the sereral loyal associations co-operating with this society be entered upon the books in the following order:1, The Crown and Cushion; 2, Black Moor's Head; 3, York Minster; 4, The Grapes; 5, The King, Oldham-street ; 6, St. Michael's ; 7, The Union; 8, Rose and Crown; 9, White Lion; 10, King's irms, Tumer-siret; 11, Queen Anne, Red Bank; 12, Crown and Shuttle.

"That fire gentlemen bo appointed delegates to attend the monthly meetings of the united delegates from the other loyal associations.

"That the following gentlemen, viz., Mr. Kearsley, Mr. T. Stott, Mr. R. Yates, Mr. Thackeray, and Mr. Webster, bo the delegateo from this associntion for the suceeding month."

“Bull's Head, Dee. 6, 1795. (Sunday!)

"Joln Sedgwiek, Esq., in the ehair;-

"Mr. John Barton and Mr. Knowell Stott admitted members of this associntion.

"Resolved,-That the thanks of this meeting be giren to Mr. Farrington and Mr. C. Marriott (the boroughreeve and one of the constables), to Mr. Leaf and Mr. Richardson, for having waited upon MIr. George Philips (in the absence of M[r. Lloyd) respecting the call of the public, to take (what is unjustly termed) the sense of the town and neighbourhood of Manchester on the question of the bills pending in parliament against seditious meetings, and for the preservation of our gracious sorereign. 
" Resolved,-That every support possible shall be given by this meeting to the other loyal associations on Monday, the 7th instant.

"Resolved,-That this and the other loyal associations be requested to meet at the New Market Hall, to-morrow morning (the 7th inst.) at ten o'clock.

"IResolved,-That James Ackers, Esq., be requested to take the chair at the meeting of the loyal inhabitants of the town and neighbourhood, agreeably to the preceding resolution.

"Reooloed,-That the address to his majesty and petition to the House of Lords, brought forward by the committee of pspers, be approved of by this association, with such alterations (if any shall bo hereafter required) as that committeo shall think necessary.

" Resolved,-That public notice of the meeting be giren by a hand-

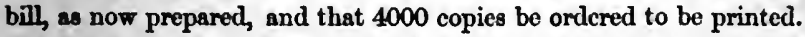

"Resolved,-That 2000 copies of the notice, that the address and petition are lying for signature at the several places mentioned in the notice be printed.

"Resolved,-That the address and petition be printed."

"Bull's Head, Dec. 7, 1795.

"John Sedgwick, Esq., in the chair ;-

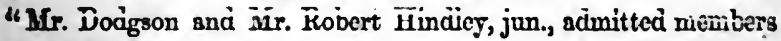
of this association.

"Resolved,-That the Duke of Bridgewater and the Right IIon. Lord Grey de Wilton be requested to present the petition to tho House of Lords, and that the address to his majesty be transmitted to the county members."

\section{"Bull's Head, Fcbruary 17th, 1797.}

"Mr. Edge in the chair; -

" Received the following resolution from the general delegates :-

"Resolved,-That this meeting fully concurs with the measure recommended by the 'Loyal Association of the Bull's Head.'

"In consequence of the abore, it was

"Resolved,-That a general meeting of the society be summoned to attend the general delegation of the several loyal associations at seren o'clock on Wednesday evening next, for the purpose of determining upon an address to all well-wishers of their king and constition, in the towns and neighbourhood of Manchester and Salford, on the propriety of immediately forming an armed rolunteer corps for their internal defence. 
"Resolved,-That Mr. Leaf, Mr. Joseph Hardman, Mr. Gatliff, Mr. IFindley, Mr. Foxley, Mr. Serjeant, and Mr. Baldwen, be requested to draw up the heads of such address.

"Resolved,-That Mr. Joln Milue be admitted a member of this nssociation."

"Bull's Head, February 22nd, 1797.

" Mr. Leaf, clainnan;-

"That the address to the people now read be approved."

"Bull's Head, January 8th, 1798.

"Mr. Kearsley, chairman;-

"Resolved,-That Mr. Hall, Mr. Foxley, Mr. R. Yates, Mr. Tetloe, and Mr. Kearsley be appointed delegates to the united meetings of the sereral loyal associations ; and that other members of this society be at liberty to attend them in the business of the delegation.

"That for the purposes of this association, a third subscription is necessary, and that the same be entered into without delay."

“ July 3rd, 1799.

"There being only sir members present, viz., Mr. Kearsley, Mr, Stott, Mr. Hall, Mr. Foxley, Mr. Harrop, and Mr. Gatliff, a com. mittee could not be formed."

\section{TIE MANCHESTER PITT CLUB.}

The events of 1812 having shown the Manchester obstructires that they could no longer control and direct public assemblages of the inhabitants, they resolved to form a Pitt Club, the committee of which could carry on the operations of the defunct society to put down levellers and republicans; while the annual dinner, commemorating the birth of the "heaven-born minister," would be a safe occasion to utter their loyal and anti-reform sentiments. The following are the resolutions passed at a meeting held at the Star Inn, on the 10th of December, 1812 :-

"That a society be instituted at Manchester, under the name of the Pitt Club, for the purpose of celebrating the birth-day of that grent, patriotic, and illustrious statesman, the Right Honourable 
Willian Pitt, and that the members do meet annually on erery 28th of May; and that the first meeting be holden upon the 28th of May, 1813.

"That any person desirous of becoming a member shall be proposed by a member of the club, at a general meeting then next succeeding; and that the gentleman proposing any new member shall declare that he knows the person proposed to be well affected to the king and constitution, and that he approres of the political principles of the late Riglit Honourable William Pitt.

"That the proposal of each person as a candidate shall be seconded, and such candidate, prorided he shall hare fire-sixths of the balls in his farour, be declared duly elected.

"That each member shall wear a medal, suspended by a blue ribbon, at the anniversary dinner, such medal to be provided by the committee for that purpose, and the medal to be paid for by each member on delivery-riz., $\$ 22$ s.

"That the following gentlemen do constitute the original members of the elub."

The names of 192 gentlemen follow, amongst whom were the following clergymen :-

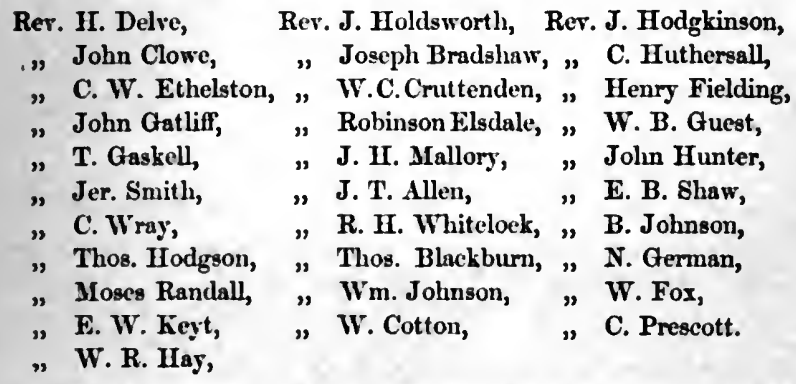

The greater part of the toasts at the anniversary dinners were too grossly indelicate to be printed at the present day. Amongst those of another class we find, in 1813, "The Land we live in, and may those who don't like it leave it;" in 1814, "Protestant Aseendaney," and "Chastisement and Humiliation to that Government which arrogantly raised its feeble arm against this Country when fighting for the Liberty of the World ;" in 1815, "Protestant Ascendancy," 
and "The best Process to bleach the Tri-Colour White." On the 15th of January, 1817, the following resolution was passed :-

"That a select committeo be formed for the purpose of preparing, printing, and circulating suitable political tracts, in order to counteract the poisonous effects of the rarious efforts which the disaffected have so recently and fully manifested; and that the following gentlemen be appointed a committeo-riz.: the Rer. Dr. Smith, Rer. Cecil Wray, Rer. J. T. Allen, Rev. Moses Randall, Mr. Simmons, Rer. Joln Gatlifr, Rer. Robinson Elsdale, Mr. Joseph Green, Mr. Thomas Jackson, Rev. C. W. Ethelston, Mr. F. Phillips, Mr. John Pooley, Mr. Thomas Hardman, Mr. E. Chesshyre, Mr. P. Crompton, Dr. Bardsley, M.D., Mr. John Wheeler, Mr. Bell, Rev. W. R. Hay, Mr. James Watkins, Mr. James Norris, Robert Peel, Esq., and Mr. Robert IIindley."

$\Lambda$ collection of the tracts published would form amusing reading at the present day. The toasts and sentiments continued to mark the subjects that suecesirely occupied the attention of the club:-

1817. - " May the Dream of Universal Sufrage and Annual Parliaments no longer disturb our repose." "The able adrocate of the Protestant Canse-The Right Hon. Robert Peel." "Suspension to all cart-politicians." "May political errors find forgireness, political crimes punishment." "Mray the languago of sedition blister the tongue that utters it." "Reformation to modern reformers."

1818. - "Tho Protestant Ascendancy." "The distinguished Secretary for Irelnnd-The Right Hon. Robert Peel, the approred supporter of our constitution in Church and State." "The Electors of Great Britain-May they ever distinguish between the empty sound of patriotism and the solid sense of it." "The Mragistrates of the Dirision, with thanks for their past and confidence in their future serrices." "May the British Constitution endure like the oak and its encmies fnll like its decayed leares."

1821.-"The Committeo of Magistrates." "Mr. Hay and the Magistrates of the Dirision, with thanks for their past and confidence in their future acrviecs." "Major Birley and the Manchester and Salford Yeomanry Caralry, with thanks to them for their past and confidence in their future services. "May the Energies of the Loyal slways defeat the Attempts of the Fictious." 
Many of the members seem to have tired of these annual eating and drinking demonstrations. At a general meeting held 7th April, 1826, the following resolutions were passed:

"That erer since the institution of this elub the number of its members has progressively increased, and yet the attendaneo at the annual celebration has considerably declined, so that more than three-fourths of the whole body have really been absent on several of "those occasions."

"That such repeated proofs of inattention of those periodical assemblies (appointed as they were for the social expression of our acknowledged principle and sentiment) materially prejudice the spirit and character of the institution, and at the same time indicate a great want of respect to the President, who obligingly undertakes the arduous duties of that situation at the request of the club."

Amongst the toasts at the annual dinner on the 29th of May, 1826, was, "Captain Grimshaw, a zealous promoter of the principles of the Pitt Club." His promotion of those principles was the eoncoction of toasts which, in our more fastidious days, would be considered as an outrage on common decency. The acknowledgment of his peculiar services does not seem to have arrested the downward progress of the association. At the annual meeting, held 5th of April, 1827, the following resolution was passed :-

"That it appears to be the prevailing sentiment of the members present, "That under the existing circumstances the usual meeting of the club for the purpose of dining be not held this year.' And notice of an intended resolution to that effeet being now giren, the subject be taken into consideration at the said annual meeting on 3rd of May."

At the meeting on the 3rd of May the following minute was made :-

"The notice of an intended motion for dispensing this year with the urual dinner was immediately withdrawn, the gentleman from whom it proceeded having expressed his decided conviction of the propriety of that course, from the riolent and important change of circumstances which had recently taken place in the government of the country."

The elub, howerer, was fast approaching to its dissolution, as the following resolutions will show :- 
"Star Inn, May 13th, 1829.

"Moced, seconded, and resolved,-That the annual dinnor be postponed to the year 1830.

"Star Inn, Manchester, April 1st, 1830.

"John Powell, Esq., in the ehair;-

"Resolved,-That there shall not be any anniversary dinner of the club this year.

“Star Inn, April 7th, 1831.

"Dr. Bardsley in the chair ; -

Resolved,-That at this important crisis of the state of the nation, the following letter be sent to erery member of this elub without delay :-

"Sir,-You are requested to address a letter to Mr. Chesshyre, the secretary, as early as possible, stating whether you will engage or not to at tend the next anniversary dinner, whieh is intended to take place on Wednesday the 1st of June, in eonsequence of the birthdny happening in the Manchester race week this year."

"Star Inn, May 5th, 1831.

"Dr. Bardsley in the chair;-

"The proceedings of the meeting of the 7 th of $A$ pril last were read by the chairman. And the result of the circular letters sent to the members pursuant to the resolution to that purpose passed at the last meeting being communicated to the meeting, and it appearing by the answers of the members that twenty-four answers were assenting to the annirersary dinner on the 1st of June next, fify-three dissentients, and seven dubious.

"Resolved,-That in consequenee of the abore result of the application to members, the annirersary dinner be postponed, and that this mbeting do adjoum to the first Thursday in April, 1832."

THE ESD. 


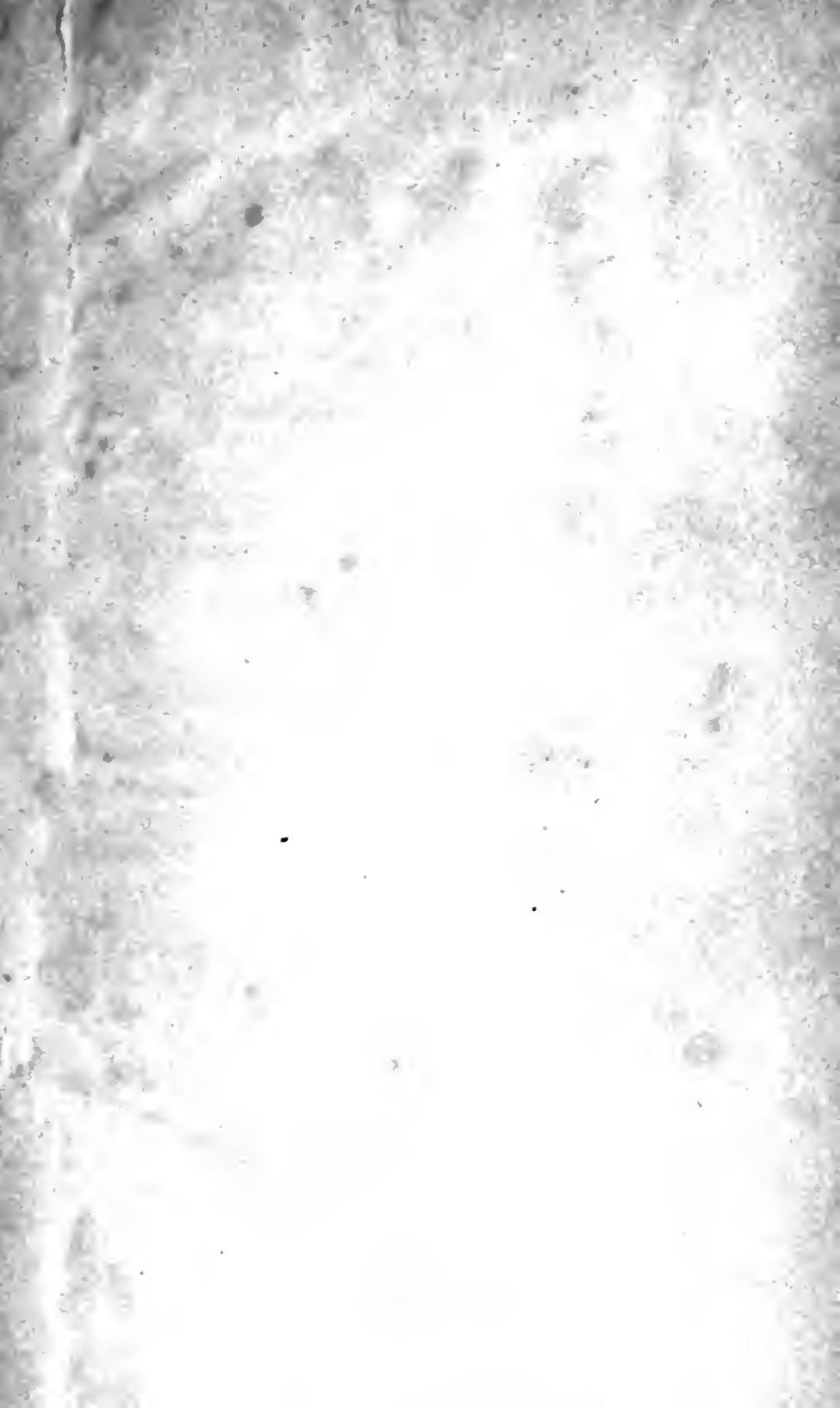


UNIVERSITY OF CALIFORNIA LIBRARY Los Ar rules

- This book is DUE on, 're stamped below. 


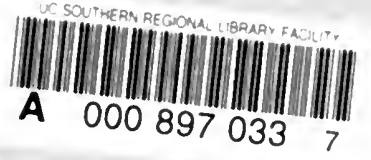


